\title{
FREQÜÊNCIA DO SULCO PALATOGENGIVAL E MORFOLOGIA DOS CANAIS DE DENTES PORTADORES ANTES E DEPOIS DO PREPARO BIOMECÂNICO
}

\section{TIAGO NOVAES PINHEIRO}

Dissertação apresentada à Faculdade de Odontologia de Bauru da Universidade de São Paulo, como parte dos requisitos para obtenção do título de Mestre em Odontologia, área de Patologia Bucal.

(Edição Revisada) 


\section{FREQÜÊNCIA DO SULCO PALATOGENGIVAL E MORFOLOGIA DOS CANAIS DE DENTES PORTADORES ANTES E DEPOIS DO PREPARO BIOMECÂNICO}

\section{TIAGO NOVAES PINHEIRO}

Dissertação apresentada à Faculdade de Odontologia de Bauru da Universidade de São Paulo, como parte dos requisitos para obtenção do título de Mestre em Odontologia, área de Patologia Bucal.

(Edição Revisada)

Orientador: Prof. Dr. Alberto Consolaro 


\section{Pinheiro, Tiago Novaes}

P655f Freqüência do sulco palatogengival e morfologia dos canais de dentes portadores antes e depois do preparo biomecânico / Tiago Novaes Pinheiro- Bauru, 2006.

172p. : il. ; $30 \mathrm{~cm}$.

Dissertação (Mestrado) - Faculdade de Odontologia de Bauru.

Orientador: Prof. Dr. Alberto Consolaro

Data de aprovação pelo comitê de Ética em pesquisa da Faculdade de Odontologia de Bauru-USP: 29 de outubro de 2003. Processo n 115/2003 A cópia do parecer de aprovação encontra-se no capítulo "Apêndice".

Autorizo, exclusivamente para fins acadêmicos e científicos, a reprodução total ou parcial desta dissertação, por processos fotocopiadores e outros meios eletrônicos.

Assinatura:

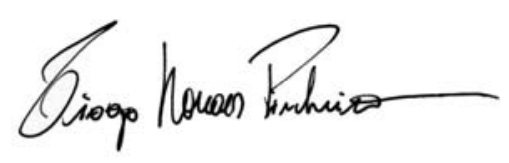

Bauru, 17 de janeiro de 2006. 


\section{Tiago Novaes Pinheiro}

02 de Julho de 1979

Filiação

$1998-2003$

$2003-2005$

Associações
Nascimento em Cachoeiro de Itapemirim, Espírito Santo, Brasil.

José Roberto Pinheiro e

Maria José Novaes Pinheiro

Curso de Graduação em Odontologia na Faculdade de Odontologia da Universidade Federal do Espírito Santo

Programa de Pós-graduação de Mestrado em Odontologia, Área de concentração em Patologia Bucal, na Faculdade de Odontologia de Bauru, Universidade de São Paulo

ABO-ES - Associação Brasileira de Odontologia seção Espírito Santo.

SBPqO - Sociedade Brasileira de Pesquisa Odontológica.

APG - Associação de Pós-graduandos da Faculdade de Odontologia de Bauru. 


\section{DEDICATÓRIA}

Dedico este trabalho à minha família:

Meus pais José Roberto Pinheiro e Maria José Novaes

Pinheiro

Minhas irmãs Mariana e Roberta Novaes Pinheiro;

Sempre presentes mesmo de longe, me dando a força essencial

para esta jornada.

Obrigado, amo

vocês! 
Dedico ainda este trabalho

Às minhas tias Elida e Sara e suas respectivas famílias.

Não tenho palavras pra agradecer por tanta ajuda e amor despendidos durante meu mestrado. 


\section{MEU AGRADECIMENTO ESPECIAL}

A Deus;

Início, meio e fim de tudo...

Que a vida seja plena e bem vivida, pois é meu bem maior!

Amém. 
Ao men orientador,

\section{Prof. Dr. Alberto Consolaro,}

Pelo exemplo de vida, pela amizade e pela orientação. Levo um pouco de ti comigo, nas minhas ações, nos meus ideais e minhas convicções.

Minha sincera amizade.

À Fundação de Amparo à Pesquisa do Estado de São Paulo -FAPESP

Pelo suporte financeiro que tornou possivel a realização deste trabalho.

Obrigado. 
Aos professores das disciplinas de Endodontia da Universidade Federal do Espirito Santo Prof. Dr. Armelindo Roldi, Prof. Dr. Francisco Carlos Ribeiro, Prof ${ }^{a}$. Dra. Rosana de Souza Pereira e Prof. Nevelton Heringer por despertar em mim o gosto pela Endodontia e sempre me incentivarem a alçar novos vôos. Em especial a Francisco Carlos Ribeiro que através de seu exemplo de vida, seus conselhos e sua amizade me fizeram buscar na Patologia a fonte de conhecimento para minha carreira acadêmica.

Às professoras da disciplina de Patologia Bucal da Universidade Federal do Espirito Santo Prof ${ }^{a}$. Dra. Maria Rosiani Dorietto Menezes,

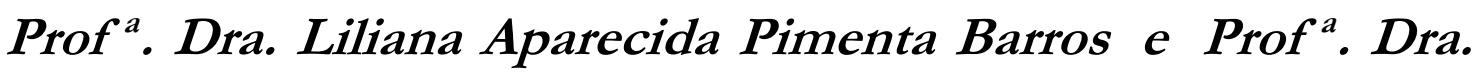
Rosa Maria Lourenço Carlos Maia pelo incentivo, convívio rico em aprendizado e por acreditarem em mim.

Minha admiração e reconhecimento à vocês! 


\section{AGRADECIMENTOS}

À Faculdade de Odontologia de Bauru da Universidade de São Paulo, através do seu atual vice-diretor em exercício, Prof. Dr. Luis Fernando Pegoraro. E ainda agradeço especialmente à Comissão de Pós-Graduação, na pessoa de seu atual presidente, Prof. Dr. José Carlos Pereira, por me incentivar de uma forma ou de outra a realizar este trabalho.

Aos Professores Doutores da Disciplina de Patologia, Luís Antônio de Assis Taveira, Denise Tostes de Oliveira e Vanessa Soares Lara, pelos ensinamentos adquiridos, convívio amistoso e pela consideração particular que me dedicaram.

À minha família da Patologia: Maria Cristina Carrara Felipe, Sr. Valdir João Afonso, Fátima Aparecida Silveira e Luís Fernando Bernardi, guardarei sempre vocês em minha memória como grandes parceiros da minha pós graduação. Contem comigo!

Ao Richerland, Oziel e Rodrigo, pela presteza e disponibilidade.

A meu amor Bethânia Camargo Pinheiro, pela companhia, amizade, carinho, compreensão e todas as demais qualidades que traduzem tudo o que temos um pelo outro, te amo. Agradeço ainda à seus pais Celso Novaes Pinheiro e Martha Camargo Pinheiro e toda a família pela acolhida e pelo carinho.

Aos amigos do curso de Mestrado: Camila, Lidiane, Luciana, Renata Consolaro, Renata Falchete e Renato pela convivência tão enriquecedora.

Aos queridos colegas da Pós-Graduação: Maria Fernanda, Leda, Carol Randón, João Adolfo, Christian, Tânia, Marta, Maria Renata, Patrícia, Rosário, Suzana, Ana Carolina, Carlos, Érika Pereira, Érika Sinara, Erick, Janaína, Simone, Karen, Melaine, Gisele, Roberta, Milton e Michele. Obrigado por tudo!

Aos professores do curso de Pós-Graduação da FOB-USP, que contribuíram para a minha formação. 
Aos Professores Doutores do Curso de Especialização em Ortodontia Arnaldo Pinzan, Fernando Castanha Henriques, Guilherme Janson, Marcos Roberto de Freitas, Décio Rodrigues Martins e Maria Fernanda MartinsOrtiz Consolaro por terem aberto as portas das clínicas para análise dos pacientes. Agradeço ainda aos especializandos por colaborarem na avaliação dos pacientes.

Ao Prof. Dr. José Mondelli e sua equipe por abrir as portas da Clínica Integrada Restauradora para a avaliação dos pacientes.

Ao Prof. Dr. Ivaldo Gomes de Moraes pela imprescindível cooperação neste trabalho através de seus conselhos, críticas e sugestões durante o processo de qualificação.

Ao Prof. Dr. Paulo Martins Ferreira e aos pós-graduandos da disciplina de Prótese Luis Gustavo Cavalcanti Bastos e Paulo Fukashi Yamaguti, pela amizade e cooperação nos trabalhos científicos paralelos que realizamos. Vocês formam uma grande equipe!

Ao Prof. Dr. José Roberto Pereira Lauris, da disciplina de Saúde Coletiva da Faculdade de Odontologia de Bauru, pelo tempo, orientações e ajuda na análise estatística.

Ao Prof. Dr. Paulo Amarante da disciplina de Materiais Dentários por disponibilizar os equipamentos e da disciplina e pela acolhida carinhosa. Aos pósgraduandos da disciplina de Materiais Dentários, Renato e principalmente ao Odirlei Malaspina por me auxiliar com os equipamentos da disciplina e cooperar para o desenvolvimento da metodologia de muflas aplicada neste trabalho.

\section{Aos amigos Maria Fernanda Martins-Ortiz Consolaro e Eduardo} Antunes Bortolizzi, pela ajuda nas clínicas, fotografando, ajudando enfim a conseguir avaliar 500 pessoas. Cada um de vocês dedicou sua amizade a mim de maneira singular durante esses anos, meu muito obrigado.

Ao amigo Luciano Tavares Ângelo Cintra pela convivência, companheirismo e pelas experiências de vida trocadas nesses últimos anos. 
Aos amigos Rodrigo Brotas Ribeiro e William Tannous Sassine que foram essenciais nos momentos mais felizes e tristes da minha vida desde a faculdade.

Aos funcionários da Disciplina de Endodontia Neide e em especial ao Edimauro, que tanto me ajudou durante as várias fases deste trabalho, grande parceiro, meu muito obrigado!

Ao funcionário da Disciplina de Matérias Dentários Alcides que me ajudou quando precisei de forma altruísta e abnegada.

Aos técnicos em microscopia eletrônica de varredura Sebastião do Instituto de Química de Araraquara-UNESP e Adriano do Departamento de Patologia da Faculdade de Odontologia de Piracicaba-UNICAMP pelos ensinamentos e auxílio com as metalizações deste trabalho.

Aos funcionários do Biotério da FOB-USP, Luiz Carlos da Silva, Erasmo Gonçalves da Silva, pela disponibilidade e ajuda nos trabalhos de pesquisa paralelos que realizei no biotério.

A todos os funcionários da Biblioteca e Documentação "Prof. Dr. Antônio Gabriel Atta", da FOB-USP, na pessoa de sua atual chefe, Cybelle de Assumpção Fontes e em especial às bibliotecárias Valéria Cristina Trindade Ferraz, Rita de Cássia Paglione, Vera Regina Casari Boccato e o Ademir Padilha, pela ajuda em todo momento, bem como aos funcionários da Reprografia, especialmente o Salvador, pela constante colaboração e amizade.

Aos colegas da Pós-Graduação de todas as áreas e aos alunos da Graduação, pelo convívio e aprendizado. 


\section{SUMÁRIO}

pág.

LISTA DE FIGURAS $\ldots \ldots \ldots \ldots \ldots \ldots \ldots \ldots \ldots \ldots \ldots \ldots \ldots \ldots \ldots \ldots \ldots \ldots \ldots \ldots \ldots \ldots \ldots \ldots \mathrm{nV}$

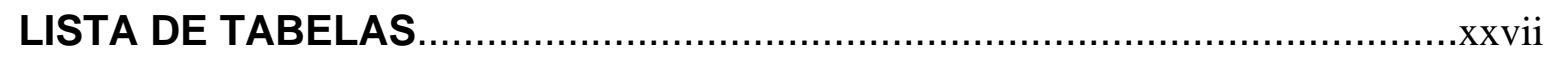

LISTA DE ABREVIATURAS, SIGLAS E SÍMBOLOS.................................xxix

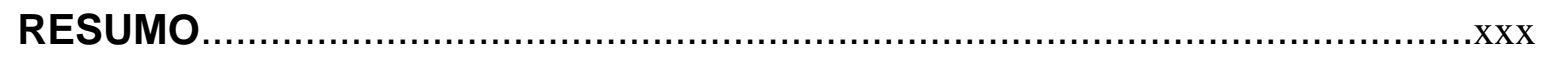

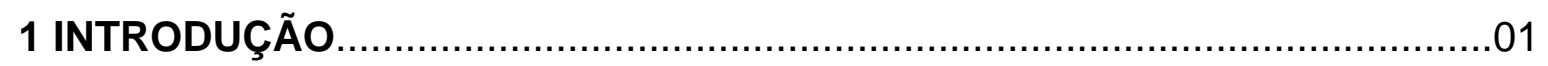

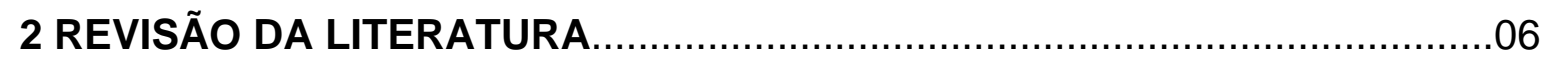

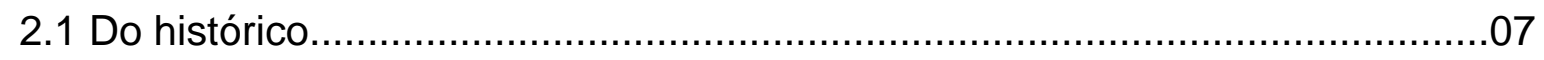

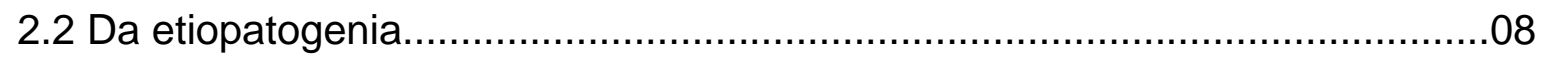

2.3 Da relevância clínica do sulco palatogengival.....................................13

2.4 Das metodologias empregadas para arealização deste trabalho..................20



2.4.2 Da análise morfológica dos dentes portadores do sulco palatogengival......25

2.4.3 Da análise da morfologia dos canais antes e depois do preparo



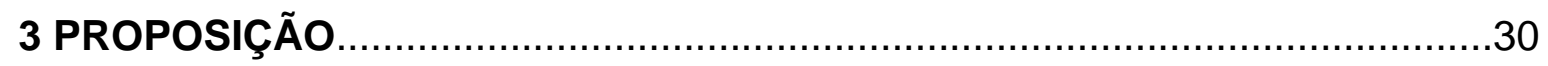

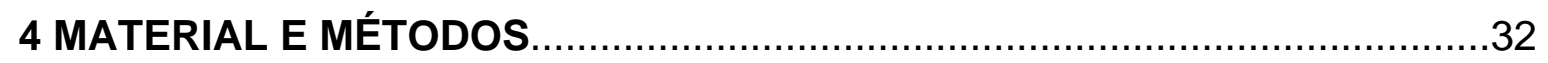

4.1 Parte A: Avaliação da freqüência do sulco palatogengival............................34



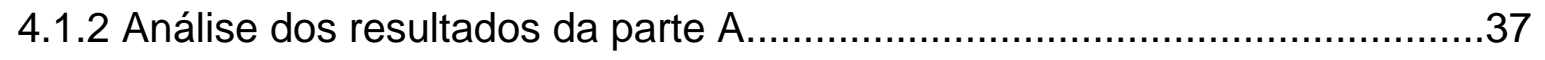

4.2 Parte B: Avaliação da morfologia dos canais e alterações morfológicas após o preparo biomecânico de dentes portadores do sulco palatogengival..................37 
4.2.1 Amostra.

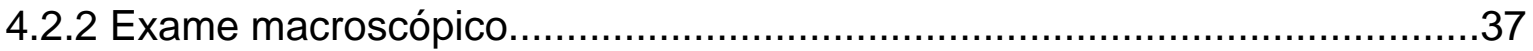

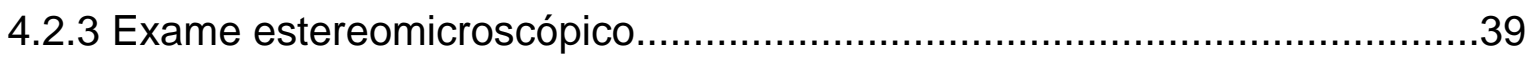

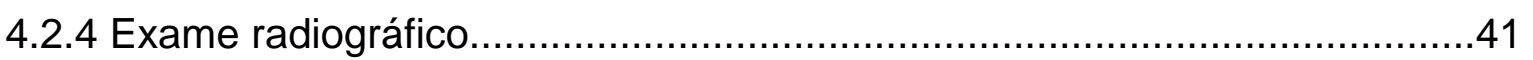

4.2.5 Análise à microscopia eletrônica de varredura....................................42

4.2.6 Preparação dos espécimes para avaliação dos efeitos do preparo biomecânico

4.2.7 Avaliação da morfologia do canal radicular antes do preparo biomecânico..49

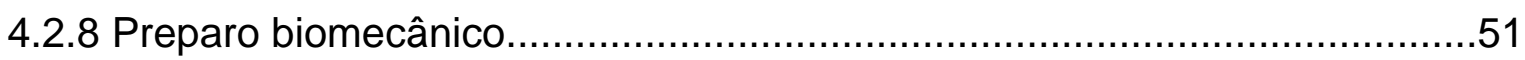

4.2.9 Análise à microscopia eletrônica de varredura.....................................52

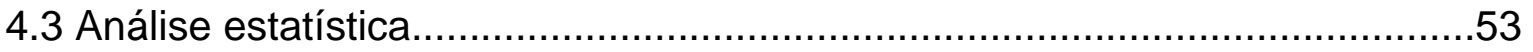





5.1.1 Freqüência do sulco palatogengival...............................................55

5.1.2 Dos resultados clínicos e radiográficos.............................................57

5.1.3 Relação do tipo facial com o sulco palatogengival................................60

5.1.4 Relação da presença do sulco palatogengival com a relação entre os arcos dentários.

5.1.5 Relação entre a forma dos arcos e o sulco palatogengival.......................63

5.1.6 Relação do sulco palatogengival com outros fatores estudados.................64

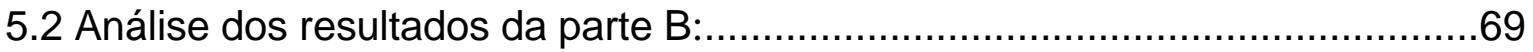

5.2.1 Exame macroscópico e estereomicroscópico.......................................69

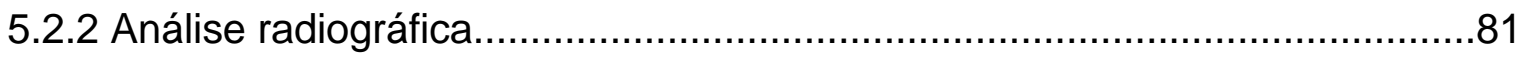

5.2.3 Análise da superfície radicular e coronária do sulco palatogengival à microscopia eletrônica de varredura. 
5.2.4 Análise das alterações morfológicas causadas pelo preparo biomecânico..95

5.2.4.1 Grupo controle... .95

5.2.4.2 Grupo experimental.

5.2.4.3 Análise comparativa do desgaste produzido pelo preparo biomecânico em diferentes paredes do conduto radicular. .106

6 DISCUSSÃO. 113

6.1 Da concepção do trabalho. .114

6.2 Da etiopatogenia do sulco palatogengival. 115

6.3 Dos resultados 121

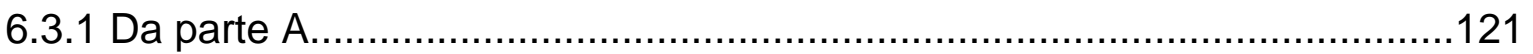

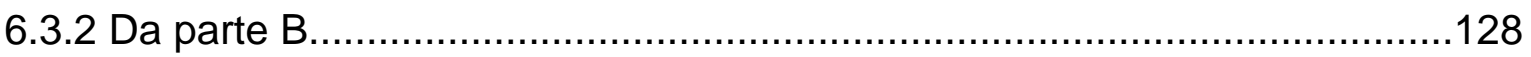

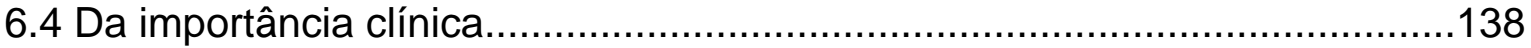

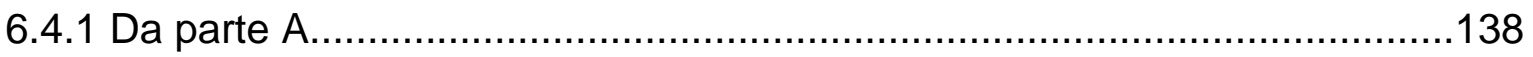



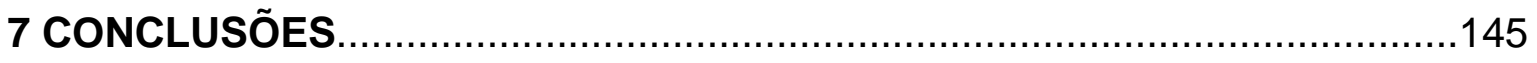

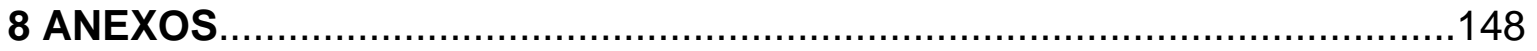

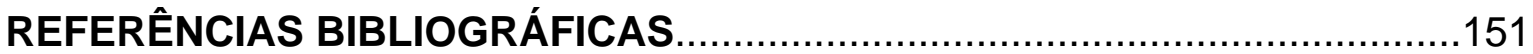

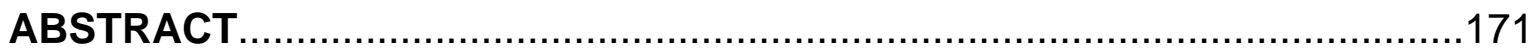

APÊNDICES 


\section{LISTA DE FIGURAS}

Representação esquemática da expressão dos genes homeobox no ectomesênquima dos processos maxilar e mandibular de embriões de ratos. (A) A expressão restrita de vários genes homeobox parece fornecer informações espaciais necessárias para determinação da forma do dente. Nas regiões proximais formadoras de molares o ectomesênquima expressa D/x-1/ -2 juntamente com Barx-1 formando os molares. Nas regiões distais formadoras de incisivos a expressão no ectomesênquima dos genes Msx-1/-2 e o Alx-3 resultam na formação dos incisivos. (B) Em ratos sem a função dos genes D/x-1/ -2 porém com a expressão do gene Barx-1, ocorre a falha no desenvolvimento tanto de molares, quanto incisivos. Enquanto o D/x-1/ -2 são dispensáveis para o desenvolvimento de molares mandibulares, são essenciais para o desenvolvimento dos molares maxilares. Deve ser enfatizado que na maxila, não são formados molares em lugar dos incisivos graças à atuação dos genes Alx-3 e Msx-1, necessários para a especificação de incisivos. (C) A manipulação da expressão dos genes homeobox resultando na expressão ectópica do Barx-1 e perda do Msx-1 (e possívelmente do Msx-2) promove a transformação do tipo de dente. Logo, o ganho de um gene de padrão de molar (Barx-1) e perda de um gene de padrão de incisivo (MsX-1) redireciona a morfogênese dos incisivos para a de molares (COBOURNE; SHARPE $2003^{37}$ )

Figura 2 Representação esquemática a partir das alterações na morfologia do contorno da cavidade pulpar e a relação da polpa, dentina e cemento com a superfície externa em dentes com sulco palatogengival, baseado na amostra de LARA, BRUCE $E$ CONSOLARO, $2000^{80}$

Figura 3A Características do individuo com tipo facial dolicocéfalo de acordo 36 com ENLOW ${ }^{44}$ E GRAY ${ }^{59}$. A aparência longilínea, estreita e longa, da face é decorrente do tamanho reduzido da base do crânio, juntamente com o posicionamento mais anterior do côndilo 
da mandíbula e mento retraído. A distância inter-orbital é pequena e os malares pouco pronunciados. O nariz é longo de aspecto romano ou aquilino, a boca possui o lábio inferior maior que o superior. O perfil do indivíduo tende a ser convexo

Figura 3B Características do individuo com tipo facial braquicéfalo de acordo com ENLOW ${ }^{44}$ E GRAY $^{59}$. Estes indivíduos possuem a face curta e larga, a sua estrutura óssea caracterizada por: base do crânio larga; mandíbula retruida e mento proeminente fazendo com que os lábios quase não apareçam. A distância inter-orbital é ampla, com malares pronunciados e nariz largo, semelhante ao de um lutador de boxe. O perfil deste indivíduo tende a ser côncavo

Figura 3C Características do individuo com tipo facial mesocéfalo de acordo com ENLOW ${ }^{44}$ E GRAY ${ }^{59}$. A aparente proporcionalidade encontrada neste indivíduo é resultante dos tamanhos ósseos intermediários. A disposição óssea propicia um perfil reto com nariz longo, mas com ápice elevado. Ambos os lábios ficam a mostra neste indivíduo com o lábio inferior ligeiramente maior que o superior

Figura 3D Relação entre os arcos proposta por ANGLE ${ }^{6}$. Tal classificação baseia-se na relação entre os primeiros molares superiores e inferiores levando em conta o posicionamento dos caninos e a posição da mandíbula. Na classe 1, a mandíbula e o arco dentário à ela superposto, estão em correta relação mesiodistal com a maxila e demais ossos da face. A cúspide mesiovestibular do primeiro molar superior oclui no sulco central do primeiro molar inferior. A classe 2 apresenta a arcada inferior em relação distal com a arcada superior. A cúspide mesiovestibular do primeiro molar superior oclui no espaço entre a cúspide vestibular do primeiro molar inferior e a face distal da cúspide vestibular do segundo pré-molar inferior, é subdividida em $1^{\circ}$ e $2^{\circ}$ subdivisão relacionada ao posicionamento dos dentes anteriores. A classe 3 tem o primeiro molar inferior em posição mesial na relação com o primeiro molar superior. A cúspide mésiovestibular do primeiro molar superior oclui no espaço entre a cúspide distal do primeiro molar inferior e a cúspide mesiovestibular do segundo molar inferior 
Figura 3E

Figura 4

Figura 5

Figura 6A

Figura 6 A

Figura 6B

Figura 6C

Figura 6D

Figura 7

Figura 8

\section{Figura 9}

Figura $10 \mathrm{~A}$, Paciente portador do sulco que apresentava bolsa periodontal com

B, C e D secreção purulenta. Realizou-se tratamento periodontal e

Três formas de arco dentário foram relevadas: ovalada com relativa curvatura anterior; triangular apresenta angulação nos incisivos centrais; quadrada quando a porção anterior é quase reta e as porções posteriores paralelas entre si

Equipamentos utilizados para o registro, captura de imagens e 40 análise dos espécimes

Microscópio eletrônico de varredura utilizado no trabalho

Molde em silicona do padrão de cera onde os dentes foram incluídos na resina acrílica. Todas as inclusões em resina foram feitas neste molde que oferecia lisura superficial e as guias transversais e longitudinais aos blocos de resina. Assim todos os blocos obtidos apresentavam as mesmas características

Esquema da inclusão do dente em bloco de resina com guias, realizado a partir de BORGES ${ }^{21}$ (1985). Neste trabalho desenvolveram-se blocos com formato de prisma de base hexagonal

Esquema da construção da mufla de gesso realizado a partir de BORGES ${ }^{21}$ (1985). Três faces do bloco de resina ficaram incluídas em cada metade da mufla, a forma de prisma de base hexagonal e o polimento do bloco têm o objetivo de facilitar a remoção do mesmo de dentro da mufla de gesso

Mufla de gesso pedra especial para o posicionamento do bloco de resina responsável por estabilizar os cortes durante o preparo biomecânico dos espécimes. Com a padronização, todas as muflas obtidas eram semelhantes

Processo preparatório para a microscopia eletrônica de varredura. 50 Nota-se o posicionamento do espécime na base metálica com esmalte incolor e o acondicionamento da amostra piloto Representação esquemática das medidas de espessura das paredes dentinárias do canal. Em azul a medida relacionada ao sulco palatogengival e em vermelho as medidas auxiliares Distribuição dos 500 pacientes examinados em relação à faixa 55 etária e o gênero 48 
restaurador, com acompanhamento de cinco semanas da recuperação clínica

Figura 11 Distribuição dos 148 casos de dentes portadores de sulco 60 palatogengival existentes entre os 500 pacientes examinados ( $\mathrm{I}=$ incisivos superiores, $\mathrm{IC}=$ incisivo central superior, $\mathrm{IL}=$ incisivo lateral superior, $B, D$ e $E=$ bilateral, direito $e$ esquerdo respectivamente)

Figura 12 Distribuição comparativa da presença e ausência do sulco palatogengival e o tipo facial na amostra de 500 pacientes examinados, 99 destes portadores do sulco palatogengival

Figuras 13 Distribuição comparativa entre pacientes examinados quanto sua relação entre os arcos de acordo com a classificação de ANGLE ${ }^{6}$ e a presença do sulco palatogengival

Figuras 14 Distribuição dos pacientes examinados quanto à forma de seus 63 arcos dentários e a presença do sulco palatogengival

Figura 15A Documentação de um paciente portador do sulco, porém sem 68 qualquer alteração nos dois dentes afetados, devido à boa higiene bucal

Figura 15B As radiografias revelam as tênues linhas radiolúcidas que partem 68 da região dos cíngulos e se estendem apicalmente em direção à crista alveolar mesial, indicando a presença do sulco (setas amarelas)

Figura 15C Características clínicas de outro paciente com sulco 68 palatogengival no dente 12 apresentando boa aparência da mucosa gengival

Figura 15D A sondagem periodontal revelou bolsa localizada com $4 \mathrm{~mm}$ de 68 profundidade e sangramento à sondagem

Figura 15E Radiograficamente observa-se o sulco palatogengival (seta 68 amarela) e perda horizontal da crista óssea alveolar devido à doença periodontal generalizada (tracejado preto). Notam-se ainda o arredondamento apical dos incisivos anteriores (setas azuis), causado por tratamento ortodôntico realizado

Figura 15F Paciente portador dos sulcos vestibular vertical e palatogengival 68 decorrentes de uma geminação dentária. Nota-se a aumento de volume gengival na face vestibular e o acúmulo de placa em todos 
os dentes, devido à higiene deficiente

Figuras 15G Destaca-se a presença de profundos sulcos palatogengivais bilaterais nos incisivos centrais. A mucosa da região da interface entre a gengiva e o sulco palatogengival encontra-se avermelhada e aumentada

Figuras $15 \mathrm{H} \quad \mathrm{Na}$ radiografia periapical observa-se o compartimento pulpar 68 anômalo do dente. Estes achados radiográficos são bem distintos daqueles encontrados em casos de sulco palatogengival comuns

Figura 15I Paciente com material restaurador devido à cárie na região do 68 cíngulo, mas o sulco palatogengival não foi diagnosticado pelo profissional

Figura 15J Maior aumento da região demonstrando o sulco palatogengival 68 pigmentado e estendendo-se apicalmente

Figura 15K Vista superior do mesmo dente demonstrando que a mucosa 68 gengival acompanha a reentrância do sulco palatogengival

Figura 15L Mesmo com ausência de sintomatologia e com profundidade de 68 sondagem de bolsa de $2 \mathrm{~mm}$ é possível observar uma discreta alteração de coloração da mucosa gengival na região do sulco

Figura 16 Visão geral da amostra antes do preparo para análise da 69 morfologia externa e interna à microscopia eletrônica de varredura

Figura 17 Analise morfológica dos espécimes 1 e 2 70

Figura 18 Aspectos morfológicos dos espécimes 3 e 4 Aspectos morfológicos dos espécimes 5 e 6 Aspectos morfológicos dos espécimes 7 e 8 Aspectos morfológicos dos espécimes 9 e 10 para microscopia eletrônica de varredura 
Figura 28B No destaque magnificação do ápice radicular revela o forame apical bastante alterado pelo processo reabsortivo, o que provoca irregularidades em seu contorno, como destacado pela linha pontilhada azul. Notam-se ainda remanescentes teciduais do conteúdo pulpar no interior do canal

Figura 28C Visão lateral do ápice radicular revela o sulco palatogengival estendendo-se em direção à região apical como uma leve depressão, seu leito está destacado pela linha pontilhada azul. As setas amarelas indicam inúmeras lacunas de Howship que promovem as irregularidades da superfície apical, algumas delas bem próximas ao sulco palatogengival, ou até envolvendo-o

Figura 29A Características morfológicas do espécime n05 com a fusão das vistas macroscópica e à microscopia eletrônica de varredura. Nota-se indicado pela linha azul pontilhada o degrau acentuado da junção amelocementária relacionado à presença do sulco palatogengival. A junção apresenta áreas onde o cemento recobre o esmalte, outras onde os tecidos relacionam-se topo a topo e ainda áreas onde existe uma relação do tipo "gap". Ainda no terço cervical da raiz, nota-se a presença de uma região compatível com reabsorção, próximo à junção amelocementária, indicado pela seta amarela. No final do terço médio ou início do terço apical da raiz, o sulco palatogengival praticamente desaparece, neste ponto, destacado pela seta azul, encontra-se um forame lateral. Já na região apical, a raiz apresenta inúmeras áreas com processo reabsortivo, deposição irregular de cemento e várias foraminas indicadas pelas setas verdes

Figura 29B A magnificação do ápice radicular deste espécime, também revelou o forame apical bastante alterado pelo processo reabsortivo, seu contorno irregular, como destacado pela linha pontilhada azul tem a aparência semelhante a uma vírgula 
invertida. Notam-se ainda algumas foraminas acessórias mencionadas anteriormente se abrindo junto ao forame principal

Figura 30A Foi constatada no espécime $n^{\circ} 14$ a continuidade da junção amelocementária na região cervical, pois o esmalte daquela área recobria o sulco palatogengival, que era pouco profundo, como indicado pela linha pontilhada azul

Figura 30B O aumento da área cervical destaca a presença de cálculo 89 dentário aderido ao leito do sulco palatogengival. Nota-se ainda o esmalte e o cemento se encontrando topo a topo praticamente por toda área registrada

Figura 30C A magnificação do cálculo dentário revela uma estrutura irregular 89 formada por aglomerados bacterianos mineralizados, tornando a região susceptível à formação de cárie ou instalação de doença periodontal

Figura 30D No espécime $n^{\circ} 12$ a junção amelocementária já se apresenta numa situação completamente diferente do caso anterior, é possível observar destacado pelas linhas tracejadas verdes, que a junção parece estar interrompida. O sulco palatogengival deste dente é tão profundo, que impede a visualização do fundo de seu leito

Figura 30E Maior aumento da porção apical da raiz acessória em seu ápice fraturado. Observa-se também uma trinca no sentido longitudinal e o lume do canal radicular bastante constrito

Figura 31 Detalhes morfológicos do espécime $n^{\circ} 15$, onde uma possível 90 invaginação do esmalte estava presente no leito do sulco palatogengival

Figura 32A Características morfológicas da secção cervical do espécime $n^{0} 7.101$ O contorno do canal principal está destacado pela linha verde. É possível observar o formato arredondado do canal, com discreta alteração em sua configuração espacial associada ao sulco palatogengival. A linha amarela revela a espessura de dentina existente entre o fundo do sulco e o canal radicular de $1,55 \mathrm{~mm}$ antes do preparo

Figura 32B $\quad$ A mesma secção observada depois do preparo biomecânico. O 101 novo contorno dado ao canal radicular é mais arredondado e uniforme, conforme a demarcação feita pela linha azul, a linha 
verde sobreposta demonstra a antiga forma do conduto. A menor distância entre o fundo do sulco e o interior do canal mudou com a instrumentação, conforme destacado pela linha vermelha, passando a 1,5mm. A pequena saliência na parede pulpar associada ao sulco palatogengival foi eliminada e a espessura dentinária no canal diminuída

Figura 32C A secção do terço médio revela a existência de dois canais 101 localizados na parte central das duas raízes, existe ainda um espaço com formado arredondado correspondente ao espaço inter-radicular. A distância entre o canal da raiz principal e o fundo do sulco é de $1,41 \mathrm{~mm}$ e do espaço inter-radicular e o canal da raiz principal de $1,14 \mathrm{~mm}$ antes da instrumentação

Figura 32D Mesma secção observada após o preparo biomecânico. A linha 101 azul demonstra o alargamento causado pelo preparo com desgaste preferencial da parede palatina do canal da raiz principal. As distâncias representadas pelas linhas vermelhas são de $1,17 \mathrm{~mm}$ de espessura de dentina entre o fundo do sulco e o canal e de 0,46mm entre o espaço inter-radicular e o canal, indicando redução de espessura.

Figura 32E O terço apical apresentou a morfologia dos condutos semelhante 101 ao terço médio. A distância entre o canal da raiz principal e o fundo do sulco é de $1,96 \mathrm{~mm}$ e do espaço inter-radicular e o canal da raiz principal de 1,22mm antes da instrumentação

Figura 32F Terço apical após o preparo biomecânico. A linha azul demonstra 101 o desgaste preferencial da parede palatina do canal da raiz principal, semelhante ao observado no terço médio. As linhas vermelhas indicam redução da espessura da dentina, 1,13mm de espessura de dentina entre o fundo do sulco e o canal; 0,58mm entre o espaço inter-radicular e o canal da raiz principal

Figura 32G Características da anatomia do espécime $n^{\circ} 7$. O canal da raiz 101 acessória inicia-se na região limítrofe entre o terço médio e o terço apical da raiz. O segundo canal não foi localizado, a radiografia do limite apical demonstra a dificuldade de observar o segundo canal Figura 33A Aspectos da morfologia da superfície radicular do espécime $\mathrm{n}^{\circ} 8$ à 103 microscopia eletrônica de varredura. Nota-se acentuado degrau na junção amelocementária causado pelo sulco palatogengival. Nos 
terços cervical e médio da raiz, observam-se acúmulos de cálculo dentário. O terço apical apresenta a superfície radicular bastante irregular devido à reabsorção e deposição desordenada de cemento

Figura 33B A secção cervical do dente revela um canal com contorno irregular 103 de aspecto elíptico destacado pela linha verde. A menor distância entre o fundo do sulco e o canal radicular é de $1,27 \mathrm{~mm}$ antes do preparo biomecânico (linha amarela)

Figura 33C Após a instrumentação observou-se o arredondamento da secção 103 do conduto, com maior remoção da camada interna de dentina das paredes vestibular e palatina do canal conforme destacado pela linha azul. A linha vermelha indica que a espessura de dentina entre o fundo do sulco e o canal diminuiu para $1,1 \mathrm{~mm}$

Figura 33D O terço médio apresentou o canal com morfologia semelhante à 103 do terço cervical. A distância entre o leito do sulco e o canal radicular era de $1 \mathrm{~mm}$ antes da instrumentação (linha amarela)

Figura 33E O desgaste da dentina causado pela instrumentação também foi 103 semelhante ao observado no teço cervical (linha azul). A linha vermelha indica que a espessura de dentina entre o fundo do sulco e o canal diminuiu para $0,73 \mathrm{~mm}$

Figura 33F Características da morfologia do canal radicular na secção apical. 103 O canal neste terço oval como observado pela linha verde. A distância entre o fundo do sulco e o canal é de $1,07 \mathrm{~mm}$ antes da instrumentação

Figura 33G Na secção do terço apical observou-se que preparo biomecânico 103 pouco diminuiu a distância entre o fundo do sulco e o canal radicular, que foi de $1,05 \mathrm{~mm}$. Apesar de o preparo promover o arredondamento da secção do canal, as paredes, vestibular e mesial sofreram maior desgaste neste espécime

Figura 33H Três perspectivas do espécime $n^{\circ}$ 8: macroscópica, radiográfica 103 antes da instrumentação e radiográfica após a instrumentação

Figura 34A A secção cervical do espécime 19 revelou o canal com forma 105 arredondada conforme destacado pela linha verde, e distância entre o fundo do sulco e o interior do canal é de 1,24mm (linha amarela)

Figura 34B Mesma secção observada após o preparo biomecânico. Nota-se o 105 
alargamento uniforme do conduto que tornou-se mais circular. A linha vermelha indica a diminuição da distância entre o fundo do sulco e o interior do canal medindo $1,15 \mathrm{~mm}$

Figura 34C No terço médio foi identificado a presença de um nódulo pulpar aderido à parede disto lingual do canal, na mesma direção do sulco palatogengival. O contorno do canal é alterado neste ponto nodular, conforme destacado pela linha verde. A menor distância entre o fundo do sulco e o interior do canal é de 1,14mm (linha amarela)

Figura 34D Mesma secção observada depois da instrumentação. A linha azul 105 demonstra o contorno circular do canal proporcionado pelo alargamento do conduto, além da remoção ou desgaste do nódulo pulpar. A distância entre o canal e o fundo do sulco caiu para 1,08mm (linha vermelha)

Figura 34E Magnificação da região destacada pelo quadro branco destacando 105 o nódulo pulpar

Figura 34F A secção apical do espécime apresentava o conduto com forma 105 elíptica antes da instrumentação (linha verde). A menor distância entre o fundo do sulco e o canal radicular é de $1 \mathrm{~mm}$

Figura 34H Depois do preparo biomecânico o contorno do conduto tornou-se 105 quase circular, com desgaste preferencial das paredes mesial e distal. A linha vermelha demonstra a diminuição da distância entre o sulco e o canal que caiu para $0,9 \mathrm{~mm}$

Figura 35 Comparação das medidas e médias das áreas do canal principal antes e depois do preparo biomecânico

Figura 36A Esquema modificado de OEHLERS ${ }^{99}$ indicando a região do 120 germe dentário que sofre dobramento na porção coronária dos incisivos superiores. Tal processo pode ser comum ao dente invaginado e ao sulco palatogengival

Figura 36B Outro esquema modificado de OEHLERS ${ }^{99}$ onde o autor classifica 120 como a invaginação do esmalte do tipo 1, que seria causado pela rotação das partes laterais do órgão do esmalte podendo resultar na fusão dos tecidos dando origem ao dente invaginado

Figura 36C Diagrama do trabalho de OEHLERS ${ }^{100}$ sobre as "variantes radiculares de dente invaginado". Nesta figura nota-se a evaginação do órgão do esmalte durante a odontogênese que irá 
dar origem à uma pérola de esmalte

Figura 36D Nesta figura, o autor elabora uma hipótese de uma invaginação em forma de botão do órgão do esmalte como uma forma invertida de pérola do esmalte, chamando-a de "invaginação radicular"

Figura 36E

A maturação das estruturas apontadas na figura $26 \mathrm{C}$ demonstrando a formação de uma pérola de esmalte

Figura 36F O autor demonstra nesta figura como ocorre o dobramento para dentro do órgão do esmalte, relacionando como uma forma invertida de pérola do esmalte. Esse raciocínio foi utilizado mais tarde para explicar a formação do sulco palatogengival

Figura 37 A, A: Secções transversais das presas de cobras venenosas proteróglifas e solenóglifas segundo WIDDOWSON ${ }^{145}$ : Nota-se em I uma presa com sulco inoculador, típico das cobras marinhas do gênero Hydrophis; em II um tipo de presa onde o sulco forma um canal inoculador, como das cobras do gênero Cobra; em III uma presa com canal fechado, característico das vipirídeas solenóglifas. Nota-se ainda: B: presa de uma cobra solenóglifa cascavel (Crotalus crotalus); C - a mesma presa após o desgaste longitudinal, revelando o canal inoculador de veneno (espécime preparado para ilustração da discussão deste trabalho). D e E Aspectos clínicos de um paciente com sulco palatogengival apresentando o sulco palatogengival bilateral nos incisivos laterais e caninos. Esses dois caninos foram os únicos encontrados na casuística, porém não foram incluídos na pesquisa sendo demonstrados apenas para relacionar com as presas das cobras

Figura 38 A, Imagens dos artigos de PEIKOFF, TROTT ${ }^{107}$ A, B e C e de 132

B, C, D, E, e F GoON et al. ${ }^{57}$ D, E e F. Observa-se na imagem A apontado pala seta vermelha uma região que pode ter perdido cemento durante o processamento laboratorial, dando a falsa impressão da extensão da profundidade do sulco, este indício é reforçado pela irregularidade em ângulos retos no contorno dos tecidos superficiais. A seta azul aponta a camada interna de dentina desgastada pela instrumentação, no artigo, os autores relatam que havia de 40-50 $\mu \mathrm{m}$ de espessura de dentina separando o cemento do compartimento pulpar. Em B e C as setas verdes destacam a 
abertura coronária do dente que teve tratamento endodôntico. $\mathrm{Na}$ imagem D GOON et al ${ }^{57}$ atribuem às irregularidades apontadas pelas setas vermelhas o status de "rede de comunicações" entre o espaço periodontal e o canal radicular. Tais estruturas poderiam ser derivadas do corte ou da montagem da lâmina, porém não há como avaliar apropriadamente o corte, pois a imagem fornecida possui um aumento de $5 X$, insuficiente para qualquer afirmação. $\mathbf{E}$ e $\mathbf{F}$ são outros cortes do mesmo espécime onde os autores afirmam que as setas negras apontam dentina displásica com fendas e ilhotas. Aumento original: A - 25X, D - 5X, E - 5X e F $10 \mathrm{X}$

Figura 39 Representação esquemática da odontoplastia na região do sulco com doença periodontal localizada modificado de ROBISON; COOLEY ${ }^{116}$

Figura 40 Retalho total revelando o defeito ósseo relacionado ao sulco palatogengival profundo. Cedido pelo Prof. Dr. Armelindo Roldi e pelo Prof. Alfredo Feitosa - UFES 


\section{LISTA DE TABELAS}

pág.

Tabela 1 Registros dos dados gerais e clínicos dos pacientes obtidos na 15 revisão sistemática

Tabela 2 Distribuição dos achados epidemiológicos de freqüência do sulco palatogengival

Tabela 3 Tabela para registro da distribuição dos aspectos característicos da presença do sulco palatogengival entre os 20 dentes avaliados morfologicamente à microscopia eletrônica de varredura

Tabela 4 Modelo da tabela para registro dos dados quanto às alterações 44 relacionadas ao sulco palatogengival na análise à microscopia eletrônica de varredura

Tabela 5 Distribuição dos pacientes da amostra quanto à presença do sulco palatogengival em relação ao gênero

Tabela 6 Distribuição dos 500 pacientes examinados quanto à presença do 56 sulco palatogengival em relação à cor da pele

Tabela 7 Distribuição dos casos de sulco palatogengival em relação à 58 profundidade de sondagem obtidos na amostra

Tabela 8 Distribuição dos pacientes e dos dentes portadores do sulco 58 palatogengival em relação à necessidade de tratamento

Tabela 9 Distribuição dos achados característicos da presença do sulco 80 palatogengival entre os 20 dentes avaliados morfologicamente

Tabela 10 Distribuição das alterações relacionadas com a presença do sulco palatogengival na análise à microscopia eletrônica de varredura

Tabela 11 Medidas em milímetros das distâncias entre o canal radicular e o 108 sulco palatogengival na interface dente-resina antes e depois do preparo biomecânico, além do desgaste causado pela instrumentação nos terços cervical (1), médio (2) e apical (3) em cada espécime analisado. As médias encontram-se na linha de tons de cinza

Tabela 12 Medidas em milímetros das distâncias auxiliares 1-3 entre o canal radicular e a interface dente-resina antes e depois do preparo biomecânico, além do desgaste causado pela instrumentação do terço cervical de cada espécime analisado. As médias encontram- 
se na linha de tons de cinza

Tabela 13 Medidas em milímetros das distâncias auxiliares 1-3 entre o canal 110 radicular e a interface dente-resina antes e depois do preparo biomecânico, além do desgaste causado pela instrumentação do terço médio de cada espécime analisado. As médias encontram-se na linha de tons de cinza

Tabela 14 Medidas em milímetros das distâncias auxiliares 1-3 entre o canal radicular e a interface dente-resina antes e depois do preparo biomecânico, além do desgaste causado pela instrumentação do terço apical de cada espécime analisado

Tabela 15 Comparação dos achados epidemiológicos de freqüência do sulco palatogengival com o presente trabalho 


\section{LISTA DE ABREVIATURAS, SIGLAS E SÍMBOLOS}

$\begin{array}{ll}\mathrm{m} & \text { - metros } \\ \mathrm{cm} & \text { - centímetro } \\ \mathrm{mm} & \text { - milímetro } \\ \mu \mathrm{m} & \text { - micrometro } \\ \mathrm{ml} & \text { - mililitro } \\ \mathrm{atm} & \text { - atmosfera } \\ \text { pH } & \text { - potencial hidrogeniônico } \\ \text { H.E. } & \text { - hematoxilina e eosina } \\ \text { LPS } & \text { - lipopolissacarídeos } \\ \text { BMP } & \text { - proteína osteomorfogenética } \\ \text { BMU } & \text { - unidade osteomodeladora } \\ \text { p } & \text { - nível de significância } \\ \text { MEV } & \text { - microscopia eletrônica de varredura } \\ \text { MTA } & \text { - agregado trióxido mineral } \\ \text { IRM } & \text { - material restaurador intermediário } \\ \text { EDTA } & \text { - ácido etileno diaminotretacético } \\ \text { CIV } & \text { - cimento de ionômero de vidro } \\ \text { EUA } & \text { - Estados Unidos da América } \\ \text { ADA } & \text { - Associação Odontológica Americana } \\ \text { CEEP } & \text { - Comissão de Ética no Ensino e Pesquisa } \\ \text { FOB } & \text { - Faculdade de Odontologia de Bauru } \\ \text { USP } & \text { - Universidade de São Paulo } \\ & \end{array}$




\section{RESUMO}

O sulco palatogengival representa uma anomalia com morfologia propícia ao acúmulo de microorganismos e possibilidade de comunicação com a cavidade pulpar, podendo acarretar em doença periodontal localizada, cárie dentária, pulpopatias e periapicopatias. Investigou-se a etiopatogenia, seus meios de diagnóstico para colaborar na determinação de prognósticos precisos baseados na detecção das dificuldades do manejo dessas situações clínicas decorrentes. Detectou-se sua freqüência em 500 pacientes, correlacionando sua presença com características pessoais e sua ocorrência na família de indivíduos portadores. Também foram utilizados 20 incisivos permanentes superiores portadores do sulco palatogengival avaliando macro e microscopicamente a morfologia dos canais radiculares antes e depois do preparo biomecânico, bem como a relação do compartimento pulpar com o meio externo. Os espécimes foram observados macroscopicamente, com o auxílio do estereomicroscópio, radiografados e analisados à microscopia eletrônica de varredura antes e depois do preparo biomecânico utilizando a técnica de mufla modificada de BRAMANTE et al.. A prevalência do sulco palatogengival na amostra de 500 pacientes avaliados, foi de $19,8 \%$, sendo que o dente mais afetado foi o incisivo lateral superior com $80,4 \%$ de prevalência, ocorrendo tanto unilateralmente quanto bilateralmente. Observou-se a prevalência de $8,4 \%$ de doenças relacionadas ao sulco. Não se detectou diferenças entre gêneros e cor de pele, quanto à presença do defeito. Não foi observada nenhuma correlação entre a presença do sulco palatogengival e as características físicas avaliadas. Identificou-se a presença do sulco palatogengival em pessoas de uma mesma família. A análise de 20 incisivos superiores com sulco palatogengival permitiu a identificação de forames, foraminas e túbulos dentinários no leito do sulco palatogengival, comunicando o compartimento pulpar com o periodontal. Identificaram-se alterações no contorno e variações do tipo de junção amelocementária. O desgaste produzido pela instrumentação dos canais nos dentes da amostra foi uniforme, não havendo diferenças significantes entre as paredes instrumentadas nem nos fragmentos cervical, médio e apical dos canais. A parede dentinária atingida pelo sulco palatogengival foi a mais fina antes e depois do preparo biomecânico. 


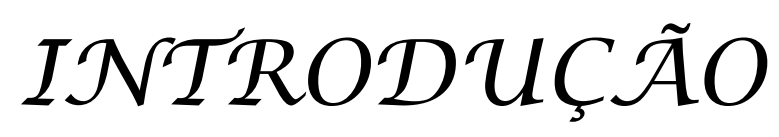




\section{INTRODUÇÃO}

O sulco palatogengival constitui uma anomalia na forma do incisivo superior humano, provavelmente muito mais freqüente do que se pode imaginar sem um levantamento epidemiológico metodizado. Ocorre predominantemente no incisivo lateral superior e pode provocar grandes danos periodontais, endodônticos e até levar à perda do dente.

O sulco palatogengival inicia-se no cíngulo dos incisivos laterais superiores, menos freqüentemente dos incisivos centrais superiores e mais raramente dos caninos superiores. Ao desviar-se geralmente para distal interrompe a continuidade da crista marginal lateral da face lingual e segue em direção apical atingindo a região cervical do dente.

No local do sulco, ao nível da junção amelocementária, o esmalte se descontinua e forma um defeito em forma de degrau na linha demarcatória cervical da coroa dentária. Na superfície proximal da raiz o sulco continua seu trajeto e termina no terço cervical, médio ou se estende até o ápice.

A profundidade do sulco palatogengival varia desde uma tênue linha no fundo de uma rasa e suave depressão, imitando uma ruga, ou até uma fissura profunda resultando em um verdadeiro dobramento da estrutura radicular imitando, às vezes, uma formação tubular. Em casos mais extremos e raros o processo dá origem a uma raiz acessória, estabelecendo-se ocasionalmente até uma possível comunicação com a cavidade pulpar ${ }^{79,80}$.

Quando o defeito acomete a superfície vestibular dos incisivos superiores, ainda que menos freqüentemente, acomete preferencialmente nos incisivos centrais superiores ${ }^{104}$; nesse caso, recebe outras nomenclaturas sendo denominado como sulco vestibular vertical ou sulco labial cervical vertical $^{63,87}$.

Os defeitos morfológicos na estrutura dentária promovidos pelo sulco palatogengival são fatores predisponentes para o aparecimento de doenças inflamatórias nos tecidos pulpares, periapicais e/ou periodontais. Estas 
alterações acometem predominantemente a face palatina dos incisivos laterais superiores e, quando diagnosticadas, estão em estádios avançados e a intervenção tardia será ineficiente.

As peculiaridades morfológicas do sulco palatogengival despertam interesse nas áreas do conhecimento, relacionadas com o diagnóstico, prevenção e tratamento de doenças como pulpopatias ${ }^{79,80,108}$, periapicopatias 79, 80, 108, 122 e periodontopatias 103, 122, 123, 142. Ao comprometer a estética e função pelas suas conseqüências, a ocorrência do sulco palatogengival induz ao desenvolvimento de técnicas e procedimentos para restabelecer a normalidade dentária e gengival com a correção da morfologia alterada ${ }^{130}$. A forma do incisivo superior promovida pelo sulco palatogengival remete a estudos antropológicos ${ }^{9}, 15,23,24,92,95,104,145$ pela sua provável origem atávica, manifestando-se em espécies de animais inferiores na escala evolutiva chegando, em alguns casos, a ter funções específicas como no caso de cobras venenosas proteróglifas e solenóglifas, onde o sulco da presa serve de leito para a inoculação da peçonha. Em algumas espécies este sulco é tão profundo que torna-se um verdadeiro conduto ${ }^{92,145 .}$

A forma afunilada do sulco palatogengival no sentido transversal promove o acúmulo de placa e de cálculo, tornando a remoção e limpeza pelo próprio paciente, ou até mesmo pelo Cirurgião-Dentista, muito dificultada ${ }^{8,75}$, 107, 108, 122, 123. A doença periodontal localizada e inflamatória decorrente, uma vez instalada, pode levar ao comprometimento pulpar direto pela profundidade do sulco e pequena espessura da dentina ou indiretamente, após envolver o ápice radicular ${ }^{7}$.

O sulco palatogengival, em alguns poucos casos, é detectável em radiografias periapicais como uma linha radiolúcida parapulpar bem definida 116, 122, 123, 129, 142. O prognóstico de doenças pulpares e/ou periapicais associadas ao sulco palatogengival não é muito favorável, pois em parte depende da extensão, da profundidade e da sua relação com a cavidade pulpar $7,27,28,69,116$. No final do tratamento endodôntico e ou periodontal, o insucesso pode decorrer da permanência de microrganismos nas partes inacessíveis da superfície do sulco palatogengival, como ocorre nas irregularidades anatômicas ou decorrentes de reabsorções dentárias ${ }^{39,55,114}$. 
Uma das abordagens terapêuticas constitui-se na raspagem e aplainamento da superfície radicular afetada 4, 5, 51, 58, 74, 90, 103, 113, 132 . Nos defeitos ósseos associados são inseridos materiais implantares com ou sem o uso simultâneo de barreiras mecânicas para prevenir o recobrimento epitelial precoce e inadequado da superfície dentária. Todos estes procedimentos objetivam a recuperação do ligamento periodontal, ou a sua acomodação por justaposição epitelial, na superfície radicular. Nem sempre isto é possível pela freqüente contaminação da superfície radicular por lipopolissacarídeos de origem bacteriana durante a fase ativa da doença periodontal inflamatória crônica previamente instalada ${ }^{116}$.

Em muitos casos, antes da exodontia procura-se o sucesso terapêutico com o aplainamento e até preparação de cavidade e restauração com materiais a base de amálgama ou cimento de ionômero de vidro, associada ao tratamento endodôntico 4, 5, 51, 58, 74, 90, 103 .

O tratamento de casos clínicos onde o sulco palatogengival não foi diagnosticado, mas estava envolvido com a origem da doença carie, doença periodontal, pulpopatias e/ou periapicopatias, tem prognóstico ruim. Isto pode resultar de tentativas de tratamento endodôntico ineficazes, pois a lesão é originalmente ou primariamente periodontal sem ou com envolvimento endodôntico, mas secundário. O tratamento deve resultar na remoção dos fatores causais e predisponentes que estão associados à placa dentobacteriana e à doença periodontal inflamatória e localizadas ${ }^{79,80}$.

Outro motivo para o insucesso do tratamento endodôntico nos dentes com sulco palatogengival é a existência de comunicações entre a polpa e o ligamento periodontal ${ }^{53,107,108,118}$.

Em 1993 e 2000, LARA e LARA, CONSOLARO e BRUCE 79, 80 correlacionaram os aspectos anatômicos do sulco palatogengival com sua etiopatogenia, diagnóstico e alternativas de tratamento, a partir da análise macro e microscópica de 13 dentes portadores extraídos e selecionados a partir de uma amostra de 20.257 dentes sem definição das causas para exodontia. Dos 13 dentes, 11 eram incisivos laterais superiores e dois centrais superiores. Havia deformação do contorno da cavidade pulpar subjacente ao 
sulco em 9 dos 13 espécimes, juntamente com uma diminuição da espessura do esmalte e dentina (11 de 13 / 13 de 13, respectivamente) simultaneamente ao aumento da espessura cementária em 12 de 13 espécimes. Observou-se extensão apical do sulco em nove espécimes e comunicação da cavidade pulpar com o compartimento periodontal em apenas um caso. A partir dos seus achados concluíram que o sulco palatogengival pode ser clinicamente diagnosticado; prevenindo assim problemas subseqüentes. Porém para uma avaliação precisa da extensão do sulco e das suas implicações danosas à estrutura dentária requer-se uma análise microscópica, pois radiograficamente esta não é possível de ser realizada a não ser, mais recentemente em cortes tomográficos transversais.

As complicações freqüentes no tratamento de dentes com sulco palatogengival e seu insucesso decorre principalmente do diagnóstico tardio. Se diagnosticado o sulco palatogengival logo após a erupção dentária, a conscientização sobre sua presença e da necessidade de procedimentos de higiene e cuidados específicos mantém indefinidamente a saúde dos tecidos vizinhos relacionados. A falta de conhecimento sobre o sulco palatogengival e suas conseqüências pelos profissionais e pacientes, mais as dificuldades de sucesso no tratamento de suas conseqüências em decorrência do diagnóstico tardio induziram nos a planejar este trabalho dividindo-o em duas partes. A primeira epidemiológica, para verificar sua freqüência na população brasileira e o grau de conhecimento sobre o sulco palatogengival. A segunda, para estudar seus aspectos morfológicos e suas possíveis implicações clínicas sugerindo-se critérios para o diagnóstico precoce e o tratamento bem sucedido. Outra pretensão no planejamento deste trabalho foi discutir a etiopatogenia deste defeito a partir dos resultados e refletir sobre os mecanismos de prevenção deste distúrbio do desenvolvimento dentário. 


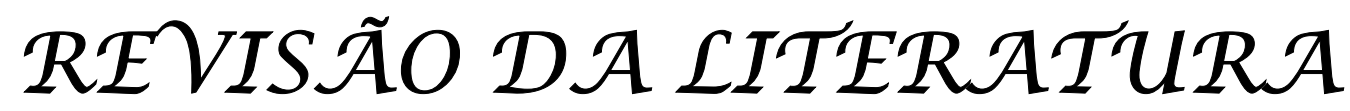




\section{REVISÃO DA LITERATURA}

A revisão da literatura está organizada por assuntos de interesse, para descrever sucintamente os estudos relevantes para o desenvolvimento deste trabalho. Inicialmente estão apresentados os trabalhos relativos à etiopatogenia e implicações clínicas do sulco palatogengival. Em seguida os trabalhos pertinentes às metodologias relacionadas a este trabalho.

\subsection{Do histórico}

O sulco palatogengival foi inicialmente descrito sem receber qualquer nome específico e sem qualquer associação com a maior probabilidade de doença periodontal localizada.

No seu livro texto sobre anatomia dentária em 1917 BROOMELL e FISCHELIS ${ }^{26}$ mencionaram um sulco na face lingual dos incisivos superiores, mas não criaram qualquer nome descritivo.

Em 1925 CAMPBELL ${ }^{29}$ também descreveu sulcos existentes na face lingual de incisivos superiores ao analisar a dentição e o palato de Arborígenes australianos, sem denominá-los.

Em 1931, ao estudar a dentição de Bantus sul-africanos, SHAW ${ }^{126}$ descreveu sulcos na face lingual de incisivos superiores e afirmou que não era comum encontrar incisivos com duas raízes, mas que quando estes sulcos eram muito profundos, pareciam que apresentavam uma tendência de gerar uma raiz dupla.

Ao analisar os dentes de esquimós em 1949, PEDERSEN 106 apresentou ilustrações de incisivos com grandes cíngulos, alguns partidos ou fendidos com sulcos desviando e quebrando a continuidade da crista marginal; entretanto não descreveu nada especificamente sobre o sulco palatogengival.

Também em 1949, ZEISZ; NUCKOLLS ${ }^{151}$ relataram cinco variações de faces linguais para os incisivos superiores de acordo com o tipo de cíngulo. Descreveram uma variante típica de incisivos laterais superiores na qual um 
sulco ou fissura segmentava o cíngulo e seguia em direção à crista marginal e se estendia para a região cervical do dente, cruzando a junção amelocementária, seguindo em direção à raiz. Entretanto, descreveu este sulco sem identifica-lo com um nome específico.

Em 1958, BRABANT ${ }^{23}$, citando Dechaume, referiu-se a uma anomalia descrita tal qual o sulco palatogengival como Anomalia SindesmoRadicular-Coronário de Chompret, Crocquefer e Chapard.

O nome "sulco palatogengival" começou a ser utilizado quando PRICHARD, em $1965^{112}$, e depois LEE, LEE e POON ${ }^{82}$ em 1968, reportaram pela primeira vez a associação entre periodontite severa localizada e esta anomalia em incisivos superiores.

No ano de 1971, no capítulo The human dentition during the megalithic era do livro de Dahlberg Dental morphology and evolution, BRABANT ${ }^{24}$ descreveu resultados sobre o sulco palatogengival obtidos em análises de coleções de dentes que datam entre os anos 2500 a 1000 a.C. Nestes dentes o sulco palatogengival estava presente em 12 a $21 \%$ de ambos os incisivos laterais e centrais e em 6,3 a 14\% em apenas um incisivo lateral superior.

\subsection{Da etiopatogenia}

A etiopatogenia do sulco palatogengival ainda permanece incógnita, apenas teorias suportam sua ocorrência. A primeira, elaborada por ATKINSON ${ }^{9}$ em 1943 caracteriza o sulco como uma deformidade relacionada à má distribuição de forças faciais durante a odontogênese que ocorreria após o período embrionário.

Outra hipótese para a etiopatogenia do sulco palatogengival foi inicialmente elaborada por LEE, LEE e POON ${ }^{82}$ em 1968, ao relacionar o sulco palatogengival com sulcos do desenvolvimento radiculares de pré-molares; em sua discussão, propõem que o sulco seria uma tentativa de formar uma raiz 
acessória. Sendo assim, considerado a organização dos tecidos envolvidos, o sulco palatogengival se enquadraria nas características de uma anomalia por redundância caracterizada pela formação numericamente aumentada de partes ou de um órgão interno.

A teoria descrita por ATKINSON ${ }^{9}$, em 1943, explica a formação do sulco palatogengival como uma deformidade do germe dentário durante sua maturação, pela má distribuição de forças no desenvolvimento craniofacial. Essa teoria explica a alta freqüência do sulco no incisivo lateral superior, pois sua mineralização ocorre posteriormente à dos dentes vizinhos, incisivo central superior, canino superior e primeiro pré-molar superior. $O$ incisivo lateral superior está nesta fase do desenvolvimento delimitado por estruturas já mineralizadas e não deformáveis. O autor atribui ainda a influência da posição mais palatina do incisivo lateral superior em desenvolvimento, da forma triangular da cripta óssea, da possível existência de vasos e nervos intimamente relacionados e da ação da língua como fatores que naturalmente interagem no posicionamento do dente no osso alveolar e em conseqüência no arco. A falta de espaço adequado para o completo desenvolvimento do germe, promoveria o seu dobramento na sua porção palatina, deformando ou dobrando o órgão do esmalte e a bainha epitelial de Hertwig com o aparecimento do sulco após a mineralização do esmalte dentina e cemento.

A dinâmica das forças que atuam no crânio e na face está relacionada com o crescimento ósseo, a oclusão, a ação dos músculos da face e da mastigação, a odontogênese e com a erupção dentária. Atuariam ainda fatores isolados como a alimentação, a respiração, a onicofagia e a sucção ${ }^{10}$, 44, 134. Durante o crescimento e o desenvolvimento facial esses fatores interagem e influenciam na determinação do tipo facial, na relação entre os arcos e no posicionamento dos dentes no arco dentário ${ }^{6,10,44}$.

Alguns estudos especulam sobre a possibilidade da formação do sulco palatogengival ocorrer como resultante de uma tentativa frustrada de formar uma raiz supranumerária $45,57,82,107,108,123$. O número de raízes provavelmente é determinado geneticamente, mas uma das teorias para explicar o aparecimento de raízes supranumerárias é a sobrecarga 
mastigatória. A presença de sulcos do desenvolvimento dentário em vários outros dentes, incluindo incisivos inferiores, pré-molares superiores e inferiores, caninos superiores e molares superiores, estariam ainda relacionados à existência dos canais "C-shape" 100.

As características como variação na profundidade do sulco; aumento da camada de cemento; diminuição da espessura da dentina; descontinuidade da linha circunferencial da junção amelocementária na região cervical; irregularidades na superfície do cemento, e alterações no contorno da cavidade pulpar; foram observados, por ENNES e LARA ${ }^{45}$, em 15 dentes com sulcos do desenvolvimento (um incisivo central, um incisivo lateral e cinco caninos inferiores, além de dois primeiros pré-molares e cinco segundos pré-molares superiores) e comparadas às dos 13 incisivos superiores com sulco palatogengival analisados minuciosamente em 1993 na dissertação de mestrado de LARA ${ }^{79}$, sob orientação do Professor Doutor Alberto Consolaro publicada em $2000^{80}$.

Os estudos moleculares relacionados à odontogênese ainda não permitem a compreensão de todos os fatores inerentes a formação das estruturas dentárias e nem mesmo explicações ao menos razoáveis para explicar a formação do sulco palatogengival.

$\mathrm{Na}$ interação dos tecidos ectodérmicos e mesenquimais, durante a odontogênese vários genes atuam em conjunto cada um a seu tempo, local e função de maneira orquestral. Enquanto a iniciação dos germes dentários necessita de sinalização epitelial que envolve moléculas pertencentes às famílias dos genes Bmp, Wnt, Fgf, e Hedgehog; a iniciação da morfogênese dentária é regulada pela sinalização de fatores de transcrição das famílias dos genes Msx-1/-2, Lef-1, Pax-9, Barx-1, Lhx-6/7, Alx-3 e Dlx-1/-2 36, 135.

O tipo morfológico do dente é determinado no início do desenvolvimento pela expressão restrita ao espaço do ectomesênquima de genes homeobox*, ou genes reguladores do desenvolvimento que controlam a

\footnotetext{
* Seqüência de aproximadamente 180 pares de bases encontrada em genes envolvidos na formação de várias partes do corpo. Nas mais diversas espécies da cadeia evolutiva encontram-se seqüências homeobox semelhantes ${ }^{135,136,137,138,139 .}$
} 
expressividade de outros genes. TUCKER et al. ${ }^{138}$ (1998) demonstraram em ratos com genes da família Dlx não funcionais, a presença de um padrão fenotípico caracterizado pela ausência do desenvolvimento dos molares, porém com todos os dentes remanescentes normais. A não expressão do gene Barx-1 causou a formação de molares no mesênquima presumidamente de incisivos.

Os domínios espaciais dos genes homeobox no ectomesênquima primordial são determinados pelo fator de crescimento fibroblástico (FGF-8) expressos proximalmente e pela proteína osteomodeladora BMP-4 expressos distalmente no epitélio bucal, restringindo-os focalmente. Sendo assim, um prépadrão proximal-distal (molar-incisivo) rudimentar de moléculas sinalizadoras está presente originariamente no epitélio.



(B) Ausência do $D / x-1 / 2$

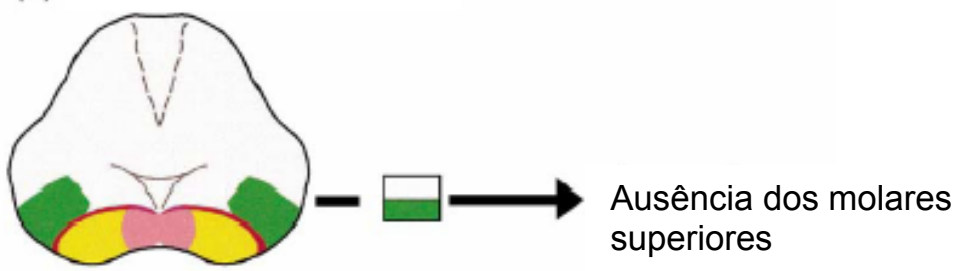

(C) Super expressão do Barx-1

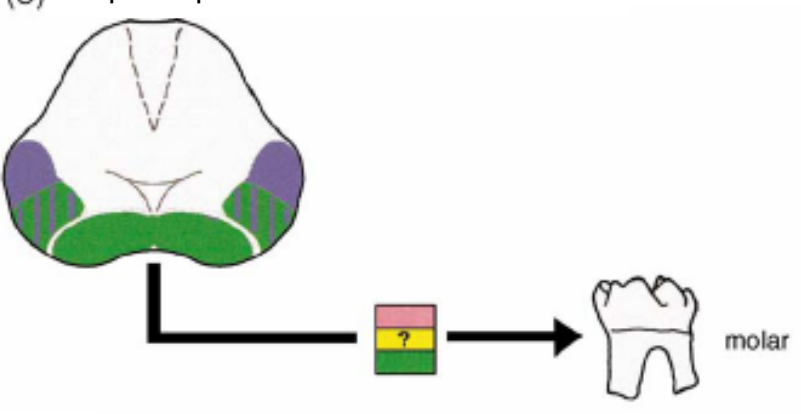

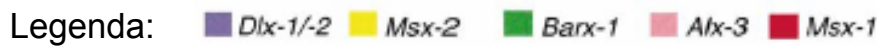

Figura 1 - Representação esquemática da expressão dos genes homeobox no ectomesênquima dos processos maxilar e mandibular de embriões de ratos. (A) A expressão restrita de vários genes homeobox parece fornecer informações espaciais necessárias para determinação da forma do dente. 
Nas regiões proximais formadoras de molares o ectomesênquima expressa Dlx-1/ -2 juntamente com Barx-1 formando os molares. Nas regiões distais formadoras de incisivos a expressão no ectomesênquima dos genes Msx-1/-2 e o Alx-3 resultam na formação dos incisivos. (B) Em ratos sem a função dos genes $D / x-1 /$-2 porém com a expressão do gene Barx-1, ocorre a falha no desenvolvimento tanto de molares, quanto incisivos. Enquanto o D/x-1/ -2 são dispensáveis para o desenvolvimento de molares mandibulares, são essenciais para o desenvolvimento dos molares maxilares. Deve ser enfatizado que na maxila, não são formados molares em lugar dos incisivos graças à atuação dos genes Alx-3 e Msx-1, necessários para a especificação de incisivos. (C) A manipulação da expressão dos genes homeobox resultando na expressão ectópica do Barx-1 e perda do Msx-1 (e possívelmente do Msx-2) promove a transformação do tipo de dente. Logo, o ganho de um gene de padrão de molar (Barx-1) e perda de um gene de padrão de incisivo (Msx-1) redireciona a morfogênese dos incisivos para a de molares (COBOURNE; SHARPE $2003^{37}$ )

As proteínas osteomodeladoras ou BMPs interagem com fatores de transcrição dos genes Msx1 e Msx2 durante a morfogênese dentária ${ }^{135}$. A forma da coroa dentária é determinada no estádio transicional da fase de botão e capuz do órgão do esmalte pela indução da BMP-4 à ação do gene Msx2 e p21 na formação do nó do esmalte. Este nó transforma-se então no centro de sinalização que regula a subseqüente morfogênese epitelial no estágio de capuz $16,70,135$. O nó do esmalte primário como outros nós secundários, formados posteriormente regulam a morfogênese do dobramento epitelial e determina o padrão e ou número cúspides. A interação da BMP4 na ativação do Msx2 também ocorre no mesênquima próximo à bainha epitelial durante a formação da raiz ${ }^{148}$. 


\subsection{Da relevância clínica do sulco palatogengival}

Ao discorrer sobre o diagnóstico diferencial de lesões endoperiodontais HARRINGTON ${ }^{64}$ em 1979 ressaltou como uma questão relevante, a sondagem profunda e restrita de uma região do sulco gengival. Nestas situações clínicas, as dificuldades diagnósticas para julgar se tal região apresenta-se acometida por um sulco palatogengival são: trato fistuloso; fratura vertical da raiz com defeito periodontal decorrente deste traumatismo dentário ou até mesmo a presença de uma pérola de esmalte ou de uma bifurcação radicular. Propôs-se que nos casos onde realmente exista um sulco palatogengival com bolsa profunda, não ocorra a intervenção endodôntica somente, pois a mesma teria pouca ou nenhuma efetividade na recuperação do sítio, sendo mais apropriado o estabelecimento de uma terapia periodontal combinada.

Os sulcos radiculares requerem atenção no diagnóstico, planejamento e tratamento periodontal e endodôntico ${ }^{17,54,63,72,77,83,123}$. A ocorrência de sulcos nas faces vestibulares de incisivos centrais superiores, nos pré-molares superiores e inferiores e em molares superiores foram relatadas como fatores responsáveis por perfurações, obturações endodônticas precárias, perda de inserção periodontal e decorrente instalação de doença periodontal inflamatória crônica e até abscessos periodontais.

A maior parte da literatura pertinente ao sulco palatogengival consiste em casuística, com soluções, técnicas e eventuais falhas na abordagem de incisivos superiores portadores e, acometidos por periodontopatia localizada, periapicopatias ou ambos. PINHEIRO, BORTOLUZZI e CONSOLARO ${ }^{109}$ (2004) analisaram por uma revisão sistemática da literatura 47 casos de sulco palatogengival relatados em 40 artigos publicados desde 1968, independentes do idioma de publicação. 0 
ano de 1968 foi determinado como demarcatório, pois foi quando publicou-se o primeiro relato de caso clínico na literatura internacional. O referido trabalho fez parte dos procedimentos preparatórios desta dissertação.

No estudo bibliométrico realizado os trabalhos foram identificados, localizados e recuperados a partir das bases de dados acessadas pelo SIBiUSP*. Todos os casos clínicos publicados foram relevados, mesmo que omitindo-se algumas informações clínicas consideradas relevantes. Os critérios de inclusão utilizados foram: relato do dente afetado; dos exames realizados; e da solução encontrada. Os registros dos dados gerais e clínicos dos pacientes obtidos na revisão sistemática e estudo bibliométrico foram tabulados de acordo com a tabela 1, assim como seu número na referência bibliográfica.

Os achados demonstraram uma maior ocorrência do sulco nos incisivos laterais superiores (39 casos), tanto unilateral quanto bilateral. $\mathrm{O}$ gênero não influenciou muito, ocorrendo um pouco mais nos homens (22 casos) do que nas mulheres (20 casos). A idade dos pacientes apresentava-se acima da terceira década de vida (35 casos) indicando que os problemas decorrentes do sulco palatogengival acontecem com o tempo de permanência do dente na boca. A terapia empregada no tratamento dos casos também mostrou-se importante, dado o elevado índice de sucesso nos casos em que o paciente foi submetido a uma terapia periodontal consistindo de raspagem e alisamento radicular (RAR) em conjunto com a odontoplastia, principalmente nos casos onde o sulco era muito profundo (14 casos). Nos casos onde além de um comprometimento periodontal também foi necessária a endodontia, notou-se um aumento no número de insucessos (3 casos). Quando o profissional optou apenas pela terapia endodôntica, não eliminando a real causa do problema, ou seja, a presença do sulco palatogengival, o insucesso foi grande ( 8 casos). Ainda houve nove casos em que o dente já estava muito comprometido, necessitando exodontia e em outros sem comprometimento algum, onde um acompanhamento e conscientização do problema foram a melhor escolha.

\footnotetext{
"Base de dados acessadas pelo SIBi-USP: BBO, BIREME, ProBE, LILACS, PUBMED SIBINET-USP e PROSSIGA.e SciELO.
} 
Tabela 1 - Registros dos dados gerais e clínicos dos pacientes obtidos na revisão sistemática

\begin{tabular}{|c|c|c|c|c|c|c|c|c|c|c|c|}
\hline \multicolumn{2}{|l|}{ CASOS } & 1 & 2 & 3 & 4 & 5 & 6 & 7 & 8 & 9 & 10 \\
\hline \multicolumn{2}{|c|}{ Número da referência bibliográfica } & 3 & 3 & 141 & 124 & 57 & 5 & 8 & 7 & 7 & 61 \\
\hline \multirow{2}{*}{ Idade } & Informa & 37 & 20 & 13 & 32 & 12 & 32 & 18 & 41 & 33 & 35 \\
\hline & Não informa & & & & & & & & & & \\
\hline \multirow{4}{*}{ Cor da pele } & Leucoderma & & & & & & $\mathrm{X}$ & & & & \\
\hline & Melanoderma & & & & & $\mathrm{X}$ & & & & & \\
\hline & Xantoderma & & & $\mathrm{X}$ & $\mathrm{X}$ & & & & & & \\
\hline & Não informa & $\bar{X}$ & $\mathrm{X}$ & & & & & $\mathrm{X}$ & $\mathrm{X}$ & $\bar{X}$ & $\bar{X}$ \\
\hline \multirow{3}{*}{ Gênero } & Masculino & $\mathrm{X}$ & $\mathrm{X}$ & $\mathrm{X}$ & & & & & & $\mathrm{X}$ & $\mathrm{X}$ \\
\hline & Feminino & & & & $X$ & $X$ & $\mathrm{X}$ & $\mathrm{X}$ & $\mathrm{X}$ & & \\
\hline & Não informa & & & & & & & & & & \\
\hline \multirow{2}{*}{ Sulco } & Palatogengival & $\bar{X}$ & $\mathrm{X}$ & $\mathrm{X}$ & $\bar{X}$ & $\mathrm{X}$ & $\mathrm{X}$ & $\mathrm{X}$ & $\mathrm{X}$ & $\bar{X}$ & $\bar{X}$ \\
\hline & Vestibular Vertical & & & & & & & & & & \\
\hline \multirow{6}{*}{$\begin{array}{l}\text { Dente } \\
\text { Afetado }\end{array}$} & 12 & $\bar{X}$ & & & $\bar{X}$ & $\bar{X}$ & & & & & \\
\hline & 22 & & $\mathrm{X}$ & $\mathrm{X}$ & & & $\mathrm{X}$ & $\mathrm{X}$ & & & \\
\hline & 12 e 22 & & & & & & & & $\mathrm{X}$ & & $\bar{X}$ \\
\hline & 11 & & & & & & & & $\mathrm{X}$ & & \\
\hline & 21 & & & & & & & & & $\bar{X}$ & \\
\hline & 11 e 21 & & & & & & & & & & \\
\hline \multirow{4}{*}{$\begin{array}{l}\text { Sintomas } \\
\text { Clínicos }\end{array}$} & Ausente & & & & & $\bar{X}$ & & & $\mathrm{X}$ & & $\mathrm{X}$ \\
\hline & Dor & $\mathrm{X}$ & $\mathrm{X}$ & $\mathrm{X}$ & $X$ & & & $\mathrm{X}$ & & $\mathrm{X}$ & \\
\hline & Edema & & & $\mathrm{X}$ & $\mathrm{X}$ & & & $\mathrm{X}$ & & $\mathrm{X}$ & \\
\hline & Postulação & & & $\mathrm{X}$ & & & $\mathrm{X}$ & $\mathrm{X}$ & & $\mathrm{X}$ & \\
\hline \multirow{4}{*}{ Pulpopatia } & Ausente & & $\mathrm{X}$ & & & $\mathrm{X}$ & $\mathrm{X}$ & $\mathrm{X}$ & $\mathrm{X}$ & & \\
\hline & Necrose pulpar & $X$ & & $\mathrm{X}$ & $X$ & & & & & & \\
\hline & Outras & & & & & & & & & & \\
\hline & Não informa & & & & & & & & & $\mathrm{X}$ & $\mathrm{X}$ \\
\hline \multirow{4}{*}{ Higiene bucal } & Boa & & & & & & & & & & \\
\hline & Regular & & & & & & & & & & \\
\hline & Ruim & & & & & & & & & & \\
\hline & Não informa & $\bar{X}$ & $\mathrm{X}$ & $\mathrm{X}$ & $\bar{X}$ & $\bar{X}$ & $\mathrm{X}$ & $\mathrm{X}$ & $\mathrm{X}$ & $\mathrm{X}$ & $\bar{X}$ \\
\hline \multirow{3}{*}{ Periodontopatia } & Presente & $\mathrm{X}$ & $X$ & $\mathrm{X}$ & $\mathrm{X}$ & & $\mathrm{X}$ & $\mathrm{X}$ & $X$ & $\mathrm{X}$ & $\mathrm{X}$ \\
\hline & Ausente & & & & & & & & & & \\
\hline & Não informa & & & & & $\mathrm{X}$ & & & & & \\
\hline \multirow{8}{*}{ Tratamento } & RAR & & & & & & $\mathrm{X}$ & & $\mathrm{X}$ & $\mathrm{X}$ & $\mathrm{X}$ \\
\hline & Endodontia & & & & & & & & & & \\
\hline & Endo/ RAR & & $\mathrm{X}$ & $\mathrm{X}$ & $\mathrm{X}$ & & & & & & \\
\hline & Odontoplastia & & & $X$ & $\mathrm{X}$ & & $\mathrm{X}$ & & $X$ & & \\
\hline & Dentística & & $\mathrm{X}$ & & & & & & & & \\
\hline & Cir. Par.ou Perio. & & & $\mathrm{X}$ & $\mathrm{X}$ & & $\mathrm{X}$ & & & $\mathrm{X}$ & $\mathrm{X}$ \\
\hline & Exodontia & $X$ & & & & $\mathrm{X}$ & & $\mathrm{X}$ & & & \\
\hline & Prevenção & & & & & & & & & & \\
\hline \multirow{2}{*}{ Acompanhamento } & Sim & & & $\mathrm{X}$ & $\bar{X}$ & $\mathrm{X}$ & $X$ & & $X$ & $\mathrm{X}$ & $\mathrm{X}$ \\
\hline & Não & $\bar{X}$ & $\mathrm{X}$ & & & & & $\mathrm{X}$ & & & \\
\hline \multirow{4}{*}{ Sucesso } & Sim & & & $\mathrm{X}$ & $\mathrm{X}$ & & $\mathrm{X}$ & & $\mathrm{X}$ & $\mathrm{X}$ & $\mathrm{X}$ \\
\hline & Não & $\bar{X}$ & & & & $\mathrm{X}$ & & $\mathrm{X}$ & & & \\
\hline & Parcial & & & & & & & & & & \\
\hline & Não informa & & $x$ & & & & & & & & \\
\hline \multirow{3}{*}{ Radiografias } & Antes & & & $\mathrm{X}$ & $\mathrm{X}$ & $\mathrm{X}$ & $\mathrm{X}$ & $\mathrm{X}$ & & & \\
\hline & Depois & & & $x$ & & & $\mathrm{X}$ & & & & \\
\hline & Não informa & $\bar{X}$ & $\mathrm{X}$ & & & & & & $\mathrm{X}$ & $\mathrm{X}$ & $\mathrm{X}$ \\
\hline & Antes & $4-5$ & 5 & 6 & 7 & & 8 & 10 & 6 & 6 & $5-6$ \\
\hline Bolsa em mm & Depois & & & 3 & 4 & & 2 & & 4 & 3 & 2 \\
\hline & Não relata & & & & & $\mathrm{X}$ & & & & & \\
\hline & Dente invaginado & & & & & & & & & & \\
\hline Outras Alterações & Raiz acessória & & & $\mathrm{X}$ & $\mathrm{X}$ & $\mathrm{X}$ & & & & & \\
\hline & Cúspide em garra & & & & & & & & & & \\
\hline
\end{tabular}


Tabela 1 - Continuação

\begin{tabular}{|c|c|c|c|c|c|c|c|c|c|c|c|}
\hline \multicolumn{2}{|l|}{ CASOS } & 11 & 12 & 13 & 14 & 15 & 16 & 17 & 18 & 19 & 20 \\
\hline \multicolumn{2}{|c|}{ Número da referência bibliográfica } & 129 & 60 & 93 & 49 & 50 & 72 & 107 & 125 & 31 & 31 \\
\hline \multirow{2}{*}{ Idade } & Informa & 17 & 41 & 29 & 24 & 49 & 60 & 28 & - & 21 & 29 \\
\hline & Não informa & & & & & & & & $\mathrm{X}$ & & \\
\hline \multirow{4}{*}{ Cor da pele } & Leucoderma & $x$ & & $\mathrm{X}$ & $\mathrm{X}$ & & $\mathrm{X}$ & & & & \\
\hline & Melanoderma & & & & & & & & & & \\
\hline & Xantoderma & & $\mathrm{X}$ & & & & & & & & \\
\hline & Não informa & & & & & $X$ & & $X$ & $\mathrm{X}$ & $X$ & $X$ \\
\hline \multirow{3}{*}{ Gênero } & Masculino & $\mathrm{X}$ & $\mathrm{X}$ & & $\mathrm{X}$ & & & & & & \\
\hline & Feminino & & & $\mathrm{X}$ & & $\mathrm{X}$ & $\mathrm{X}$ & $\bar{X}$ & & $\mathrm{X}$ & $\mathrm{X}$ \\
\hline & Não informa & & & & & & & & $\mathrm{X}$ & & \\
\hline \multirow{2}{*}{ Sulco } & Palatogengival & $x$ & $\mathrm{X}$ & $\mathrm{X}$ & $\mathrm{X}$ & $\mathrm{X}$ & $\mathrm{X}$ & $\mathrm{X}$ & $\mathrm{X}$ & $\mathrm{X}$ & $\mathrm{X}$ \\
\hline & Vestibular Vertical & $\mathrm{X}$ & & & & & & & & & \\
\hline \multirow{6}{*}{$\begin{array}{l}\text { Dente } \\
\text { Afetado }\end{array}$} & 12 & $\mathrm{X}$ & & $X$ & & $\mathrm{X}$ & & & & $\mathrm{X}$ & \\
\hline & 22 & & $\mathrm{X}$ & & $\mathrm{X}$ & & & $X$ & & & $\mathrm{X}$ \\
\hline & 12 e 22 & & & & & & & & & & \\
\hline & 11 & & & & & & & & & & \\
\hline & 21 & & & & & & & & $\mathrm{X}$ & & \\
\hline & 11 e 21 & & & & & & $\mathrm{X}$ & & & & \\
\hline \multirow{4}{*}{$\begin{array}{l}\text { Sintomas } \\
\text { Clínicos }\end{array}$} & Ausente & & $\mathrm{X}$ & & & $\mathrm{X}$ & & & & $\mathrm{X}$ & $\mathrm{X}$ \\
\hline & Dor & $\mathrm{X}$ & & $\mathrm{X}$ & $\mathrm{X}$ & & $\mathrm{X}$ & & & & \\
\hline & \begin{tabular}{|l|} 
Edema \\
\end{tabular} & & & & & & $\mathrm{X}$ & $X$ & & & \\
\hline & Pustulação & & & & & & & & $X$ & & \\
\hline \multirow{4}{*}{ Pulpopatia } & Ausente & & & & & $\mathrm{X}$ & $\mathrm{X}$ & & & & \\
\hline & Necrose pulpar & $\mathrm{X}$ & $\mathrm{X}$ & $X$ & & & $\mathrm{X}$ & $X$ & & $\mathrm{X}$ & $\mathrm{X}$ \\
\hline & Outras & & & & $\mathrm{X}$ & & & & & & \\
\hline & Não informa & & & & & & & & $\mathrm{X}$ & & \\
\hline \multirow{4}{*}{ Higiene bucal } & Boa & & & & & & & & & & \\
\hline & Regular & & & & & & & & & & \\
\hline & Ruim & & $X$ & & & & $X$ & & & & \\
\hline & Não fala & $\mathrm{X}$ & & $\mathrm{X}$ & $\mathrm{X}$ & $\mathrm{X}$ & & $\mathrm{X}$ & $\mathrm{X}$ & $\mathrm{X}$ & $\mathrm{X}$ \\
\hline \multirow{3}{*}{ Periodontopatia } & Presente & & $\mathrm{X}$ & & & $\mathrm{X}$ & $\mathrm{X}$ & & $\mathrm{X}$ & $\mathrm{X}$ & $\mathrm{X}$ \\
\hline & Ausente & & & & $\mathrm{X}$ & & & & & & \\
\hline & Não informa & $\mathrm{X}$ & & $\mathrm{X}$ & & & & & & & \\
\hline \multirow{8}{*}{ Tratamento } & RAR & & & & & $\mathrm{X}$ & & & & & \\
\hline & Endodontia & $\mathrm{X}$ & & $\mathrm{X}$ & $\mathrm{X}$ & & & $\mathrm{X}$ & & & \\
\hline & Endo/ RAR & & $\mathrm{X}$ & & & & $\mathrm{X}$ & & & $\mathrm{X}$ & $\mathrm{X}$ \\
\hline & Odontoplastia & & & & & & & & & & \\
\hline & Dentística & & & & & & & & $\mathrm{X}$ & & \\
\hline & Cir. Par.ou Perio. & & $\mathrm{X}$ & $\mathrm{X}$ & $\mathrm{X}$ & $\mathrm{X}$ & $\mathrm{X}$ & $\bar{X}$ & $\mathrm{X}$ & & \\
\hline & Exodontia & & & $X$ & & & & $X$ & & & \\
\hline & Prevenção & & & & & & & & & & \\
\hline \multirow{2}{*}{ Acompanhamento } & Sim & & $\mathrm{X}$ & $\mathrm{X}$ & $\mathrm{X}$ & $\mathrm{X}$ & $\mathrm{X}$ & $\bar{x}$ & & $\mathrm{X}$ & $\mathrm{X}$ \\
\hline & Não & $\mathrm{X}$ & & & & & & & $\mathrm{X}$ & & \\
\hline \multirow{4}{*}{ Sucesso } & Sim & & & & & $\mathrm{X}$ & $\mathrm{X}$ & & & $\mathrm{X}$ & $\mathrm{X}$ \\
\hline & Não & & $X$ & $X$ & $\mathrm{X}$ & & & $X$ & & & \\
\hline & Parcial & & & & & & & & & & \\
\hline & Não informa & $x$ & & & & & & & $\mathrm{X}$ & & \\
\hline \multirow{3}{*}{ Radiografias } & Antes & $\mathrm{X}$ & $\mathrm{X}$ & $\mathrm{X}$ & $\mathrm{X}$ & $\mathrm{X}$ & $\mathrm{X}$ & $\mathrm{X}$ & & $\mathrm{X}$ & $\mathrm{X}$ \\
\hline & Depois & & & & $\mathrm{X}$ & $\mathrm{X}$ & $\mathrm{X}$ & $\bar{X}$ & & $\mathrm{X}$ & $\mathrm{X}$ \\
\hline & Não informa & & & & & & & & $\mathrm{X}$ & & \\
\hline & Antes & 4 & & & & 8 & & & 8 & 12 & 10 \\
\hline Bolsa em mm & Depois & & & & 8 & 3 & 2 & & & 3 & 3 \\
\hline & Não relata & & $\mathrm{X}$ & $\mathrm{X}$ & & & & $\mathrm{X}$ & & & \\
\hline & Dente invaginado & & & & & & & & & & \\
\hline Outras Alterações & Raiz acessória & & $\mathrm{X}$ & $\mathrm{X}$ & $\mathrm{X}$ & & & $\mathrm{X}$ & & & \\
\hline & Cúspide em garra & & & & $\mathrm{X}$ & & & & & & \\
\hline
\end{tabular}


Tabela 1 - Continuação

\begin{tabular}{|c|c|c|c|c|c|c|c|c|c|c|c|}
\hline \multirow{2}{*}{\multicolumn{2}{|c|}{$\begin{array}{l}\text { CASOS } \\
\text { Número da referência bibliográfica }\end{array}$}} & 21 & 22 & 23 & 24 & 25 & 26 & 27 & 28 & 29 & 30 \\
\hline & & 141 & 51 & 66 & 102 & 86 & 86 & 58 & 58 & 58 & 48 \\
\hline \multirow{2}{*}{ Idade } & Informa & - & 28 & 33 & 38 & 19 & 26 & - & - & - & 25 \\
\hline & Não informa & $X$ & & & & & & $X$ & $X$ & $\mathrm{X}$ & \\
\hline \multirow{4}{*}{ Cor da pele } & Leucoderma & & $x$ & & & & & & & & $\mathrm{X}$ \\
\hline & Melanoderma & & & & & & & & & & \\
\hline & Xantoderma & $\mathrm{X}$ & & & $\mathrm{X}$ & & & & & & \\
\hline & Não informa & & & $\mathrm{X}$ & & $\mathrm{X}$ & $X$ & $\mathrm{X}$ & $\mathrm{X}$ & $\mathrm{X}$ & \\
\hline \multirow{3}{*}{ Gênero } & Masculino & $\mathrm{X}$ & $\mathrm{X}$ & $\mathrm{X}$ & $\bar{X}$ & & $\mathrm{X}$ & & & & \\
\hline & Feminino & & & & & $\mathrm{X}$ & & & & & $\mathrm{X}$ \\
\hline & Não informa & & & & & & & $\mathrm{X}$ & $\mathrm{X}$ & $\mathrm{X}$ & \\
\hline \multirow{2}{*}{ Sulco } & Palatogengival & $\mathrm{X}$ & $\mathrm{X}$ & $\mathrm{X}$ & $\mathrm{X}$ & $\mathrm{X}$ & $\mathrm{X}$ & $\mathrm{X}$ & $X$ & $\mathrm{X}$ & $\mathrm{X}$ \\
\hline & Vestibular Vertical & & & & & & & & & & \\
\hline \multirow{6}{*}{$\begin{array}{l}\text { Dente } \\
\text { Afetado }\end{array}$} & 12 & & & & & $\mathrm{X}$ & $X$ & & $\mathrm{X}$ & & \\
\hline & 22 & $X$ & $X$ & $X$ & & & & $X$ & & & $X$ \\
\hline & 12 e 22 & & & & $\mathrm{X}$ & & & & & & \\
\hline & 11 & & & & & & & & & & \\
\hline & 21 & & & & & & & & & $\mathrm{X}$ & \\
\hline & 11 e 21 & & & & & & & & & & \\
\hline \multirow{4}{*}{$\begin{array}{l}\text { Sintomas } \\
\text { Clínicos }\end{array}$} & Ausente & & & & & & & & & $\mathrm{X}$ & \\
\hline & Dor & & $X$ & & $\mathrm{X}$ & $X$ & $X$ & $\mathrm{X}$ & $\mathrm{X}$ & & $X$ \\
\hline & Edema & $X$ & $\mathrm{X}$ & & $\mathrm{X}$ & & $X$ & & & & \\
\hline & Pustulação & & & $\mathrm{X}$ & $\mathrm{X}$ & & & & & & \\
\hline \multirow{4}{*}{ Pulpopatia } & Ausente & & & & $\mathrm{X}$ & & & & & & $\mathrm{X}$ \\
\hline & Necrose pulpar & & $\mathrm{X}$ & $\mathrm{X}$ & $\mathrm{X}$ & $\mathrm{X}$ & $\mathrm{X}$ & $\mathrm{X}$ & $\mathrm{X}$ & $\mathrm{X}$ & \\
\hline & Outras & & & & & & & & & & \\
\hline & Não informa & $\mathrm{X}$ & & & & & & & & & \\
\hline \multirow{4}{*}{ Higiene bucal } & Boa & & & & & & & & & & \\
\hline & Regular & & & & & & & & & & \\
\hline & Ruim & & & & & & & & & & \\
\hline & Não fala & $\mathrm{X}$ & $X$ & $\mathrm{X}$ & $\mathrm{X}$ & $\mathrm{X}$ & $X$ & $\mathrm{X}$ & $\mathrm{X}$ & $X$ & $X$ \\
\hline \multirow{3}{*}{ Periodontopatia } & Presente & $\mathrm{X}$ & $\mathrm{X}$ & $\mathrm{X}$ & $\mathrm{X}$ & $\mathrm{X}$ & $\mathrm{X}$ & $\mathrm{X}$ & & $\mathrm{X}$ & $\mathrm{X}$ \\
\hline & Ausente & & & & & & & & & & \\
\hline & Não informa & & & & & & & & $\mathrm{X}$ & & \\
\hline \multirow{8}{*}{ Tratamento } & RAR & & & & & & & & & & \\
\hline & Endodontia & & & & $\bar{X}$ & $\mathrm{X}$ & $\mathrm{X}$ & & $\mathrm{X}$ & & \\
\hline & Endo/ RAR & & $\mathrm{X}$ & $\mathrm{X}$ & & & & & & $\mathrm{X}$ & \\
\hline & Odontoplastia & $\mathrm{X}$ & $\mathrm{X}$ & & & $\mathrm{X}$ & & & & & \\
\hline & Dentística & $\mathrm{X}$ & $\mathrm{X}$ & & & & & & & & \\
\hline & Cir. Par.ou Perio. & $\mathrm{X}$ & & & & $\mathrm{X}$ & & & & $\mathrm{X}$ & \\
\hline & Exodontia & & & & $X$ & $\mathrm{X}$ & $\mathrm{X}$ & $\mathrm{X}$ & $X$ & & $\mathrm{X}$ \\
\hline & Prevenção & & & & & & & & & & \\
\hline \multirow{2}{*}{ Acompanhamento } & Sim & $\mathrm{X}$ & $\mathrm{X}$ & $\mathrm{X}$ & $\bar{X}$ & $\mathrm{X}$ & $\mathrm{X}$ & & & $\mathrm{X}$ & \\
\hline & Não & & & & & & & $\mathrm{X}$ & $\mathrm{X}$ & & $\mathrm{X}$ \\
\hline \multirow{4}{*}{ Sucesso } & Sim & $\mathrm{X}$ & $\mathrm{X}$ & & & & & & & $\mathrm{X}$ & \\
\hline & Não & & & & $\mathrm{X}$ & $\mathrm{X}$ & $\mathrm{X}$ & $\mathrm{X}$ & $\mathrm{X}$ & & $\mathrm{X}$ \\
\hline & Parcial & & & $X$ & & & & & & & \\
\hline & Não informa & & & & & & & & & & \\
\hline \multirow{3}{*}{ Radiografias } & Antes & $\mathrm{X}$ & $\mathrm{X}$ & $\mathrm{X}$ & $\mathrm{X}$ & & $\mathrm{X}$ & $\mathrm{X}$ & $X$ & $\mathrm{X}$ & $\mathrm{X}$ \\
\hline & Depois & $\mathrm{X}$ & $\mathrm{X}$ & $\mathrm{X}$ & & & $\mathrm{X}$ & & & $\mathrm{X}$ & \\
\hline & Não informa & & & & & $\mathrm{X}$ & & & & & \\
\hline \multirow{3}{*}{ Bolsa em mm } & Antes & 6 & 3 & 10 & $3-5$ & 6 & 8 & 10 & & 9 & 10 \\
\hline & Depois & & 8 & 8 & & & & & & 4 & \\
\hline & Não relata & & & & & & & & $X$ & & \\
\hline & Dente invaginado & $X$ & & & & & & & & & \\
\hline Outras Alterações & Raiz acessória & & & & & & & & & & \\
\hline & Cúspide em garra & $X$ & & & & & & & & & \\
\hline
\end{tabular}


Tabela 1 - Continuação

\begin{tabular}{|c|c|c|c|c|c|c|c|c|c|c|c|}
\hline \multirow{2}{*}{\multicolumn{2}{|c|}{$\begin{array}{l}\text { CASOS } \\
\text { Número da referência bibliográfica }\end{array}$}} & 31 & 32 & 33 & 34 & 35 & 36 & 37 & 38 & 39 & 40 \\
\hline & & 48 & 48 & 48 & 48 & 48 & 108 & 113 & 90 & 69 & 82 \\
\hline \multirow{2}{*}{ Idade } & Informa & 33 & 38 & 45 & 39 & 17 & 34 & 32 & 32 & 50 & 34 \\
\hline & Não informa & & & & & & & & & & \\
\hline \multirow{4}{*}{ Cor da pele } & Leucoderma & $\mathrm{X}$ & $\mathrm{X}$ & $X$ & $\mathrm{X}$ & $\mathrm{X}$ & & & & & \\
\hline & Melanoderma & & & & & & & & & & \\
\hline & Xantoderma & & & & & & & & & & $\mathrm{X}$ \\
\hline & Não informa & & & & & & $\mathrm{X}$ & $\mathrm{X}$ & $\mathrm{X}$ & $\mathrm{X}$ & \\
\hline \multirow{3}{*}{ Gênero } & Masculino & & & & & $X$ & $\mathrm{X}$ & $\mathrm{X}$ & & $X$ & $\mathrm{X}$ \\
\hline & Feminino & $\mathrm{X}$ & $\mathrm{X}$ & $\mathrm{X}$ & $\mathrm{X}$ & & & & $\mathrm{X}$ & & \\
\hline & Não informa & & & & & & & & & & \\
\hline \multirow{2}{*}{ Sulco } & Palatogengival & $\mathrm{X}$ & $\bar{X}$ & $\mathrm{X}$ & $\mathrm{X}$ & $\bar{X}$ & $\mathrm{X}$ & $\mathrm{X}$ & $\bar{x}$ & $\bar{X}$ & $\mathrm{X}$ \\
\hline & Vestibular Vertical & & & & & & & & & & \\
\hline \multirow{6}{*}{$\begin{array}{l}\text { Dente } \\
\text { Afetado }\end{array}$} & 12 & $\mathrm{X}$ & & $\mathrm{X}$ & $\mathrm{X}$ & & & & $\mathrm{X}$ & & \\
\hline & 22 & & & & & $\bar{X}$ & $\mathrm{X}$ & & & & \\
\hline & 12 e 22 & & $\mathrm{X}$ & & & & & $\mathrm{X}$ & & $\mathrm{X}$ & \\
\hline & 11 & & & & & & & & & & \\
\hline & 21 & & & & & & & & & & $X$ \\
\hline & 11 e 21 & & & & & & & & & & \\
\hline \multirow{4}{*}{$\begin{array}{l}\text { Sintomas } \\
\text { Clínicos }\end{array}$} & Ausente & & & & $\mathrm{X}$ & $\mathrm{X}$ & & $\mathrm{X}$ & $\mathrm{X}$ & $\mathrm{X}$ & $\mathrm{X}$ \\
\hline & Dor & $\mathrm{X}$ & & & & & $\mathrm{X}$ & & & $\mathrm{X}$ & \\
\hline & Edema & & $\mathrm{X}$ & $\mathrm{X}$ & & & & & & $\mathrm{X}$ & \\
\hline & Pustulação & & & & & & & & & & \\
\hline \multirow{4}{*}{ Pulpopatia } & Ausente & & $\bar{X}$ & & $\mathrm{X}$ & $\mathrm{X}$ & & $\mathrm{X}$ & & $\bar{X}$ & $\mathrm{X}$ \\
\hline & Necrose pulpar & & & & & & $\mathrm{X}$ & & & & \\
\hline & Outras & & & & & & & & $\mathrm{X}$ & & \\
\hline & Não informa & $\mathrm{X}$ & & $\mathrm{X}$ & & & & & & & \\
\hline \multirow{4}{*}{ Higiene bucal } & Boa & & & & & & & $\mathrm{X}$ & $\mathrm{X}$ & $\mathrm{X}$ & \\
\hline & Regular & & & & & & & & & & \\
\hline & Ruim & & & & & & & & & & \\
\hline & Não fala & $\mathrm{X}$ & $\bar{X}$ & $\mathrm{X}$ & $\mathrm{X}$ & $\bar{X}$ & $\mathrm{X}$ & & & & $\mathrm{X}$ \\
\hline \multirow{3}{*}{ Periodontopatia } & Presente & $X$ & $\mathrm{X}$ & $X$ & & & $\mathrm{X}$ & $\mathrm{X}$ & $X$ & $X$ & $\mathrm{X}$ \\
\hline & Ausente & & & & $\mathrm{X}$ & $\mathrm{X}$ & & & & & \\
\hline & Não informa & & & & & & & & & & \\
\hline \multirow{8}{*}{ Tratamento } & RAR & & & & & & & $\mathrm{X}$ & & $\mathrm{X}$ & $\mathrm{X}$ \\
\hline & Endodontia & & & & & & $\mathrm{X}$ & & $\mathrm{X}$ & & \\
\hline & Endo/ RAR & & & & & & & & & & \\
\hline & Odontoplastia & & & & & & & $\mathrm{X}$ & $\mathrm{X}$ & $X$ & \\
\hline & Dentística & & & & & & & & & & \\
\hline & Cir. Par.ou Perio. & & $\bar{X}$ & & & & & $\mathrm{X}$ & $\bar{X}$ & $\mathrm{X}$ & \\
\hline & Exodontia & $\mathrm{X}$ & & $\mathrm{X}$ & & & $\mathrm{X}$ & & & & $\mathrm{X}$ \\
\hline & Prevenção & & & & $\mathrm{X}$ & $\mathrm{X}$ & & & & & \\
\hline \multirow{2}{*}{ Acompanhamento } & Sim & & $\mathrm{X}$ & & & & & $\mathrm{X}$ & $X$ & $\mathrm{X}$ & $\mathrm{X}$ \\
\hline & Não & $\mathrm{X}$ & & $\mathrm{X}$ & $\mathrm{X}$ & $\mathrm{X}$ & $\mathrm{X}$ & & & & \\
\hline \multirow{4}{*}{ Sucesso } & Sim & & $\mathrm{X}$ & & $\mathrm{X}$ & $\mathrm{X}$ & & $\mathrm{X}$ & $\mathrm{X}$ & $\mathrm{X}$ & \\
\hline & Não & $\mathrm{X}$ & & $\mathrm{X}$ & & & $\mathrm{X}$ & & & & $\mathrm{X}$ \\
\hline & Parcial & & & & & & & & & & \\
\hline & Não informa & & & & & & & & & & \\
\hline \multirow{3}{*}{ Radiografias } & Antes & $\mathrm{X}$ & $\mathrm{X}$ & $\mathrm{X}$ & $\mathrm{X}$ & $\mathrm{X}$ & $\mathrm{X}$ & $\mathrm{X}$ & $\mathrm{X}$ & $\mathrm{X}$ & $\mathrm{X}$ \\
\hline & Depois & & & & & & & $\mathrm{X}$ & $\bar{X}$ & $\mathrm{X}$ & \\
\hline & Não informa & & & & & & & & & & \\
\hline \multirow{3}{*}{ Bolsa em mm } & Antes & 9 & & 7 & 2 & 2 & 7 & 11 & 8 & 10 & 8 \\
\hline & Depois & & & & & & & $2-3$ & 3 & 3 & \\
\hline & Não relata & & $\mathrm{X}$ & & & & & & & & \\
\hline & Dente invaginado & & & & & & & & & & \\
\hline Outras Alterações & Raiz acessória & & & & & & $\mathrm{X}$ & & & & \\
\hline & Cúspide em garra & & & & & & & & & & \\
\hline
\end{tabular}


Tabela 1 - Continuação

\begin{tabular}{|c|c|c|c|c|c|c|c|c|c|}
\hline \multicolumn{2}{|l|}{ CASOS } & 41 & 42 & 43 & 44 & 45 & 46 & 47 & TOTAL \\
\hline \multicolumn{2}{|c|}{ Número da referência bibliográfica } & 46 & 143 & 74 & 131 & 27 & 116 & 132 & 40 artigos \\
\hline \multirow{2}{*}{ Idade } & Informa & 58 & 22 & 37 & 31 & 32 & 45 & 21 & \multirow{2}{*}{$\begin{array}{l}\text { Média de } 32 \\
\text { anos de idade }\end{array}$} \\
\hline & Não informa & & & & & & & & \\
\hline \multirow{4}{*}{ Cor da pele } & Leucoderma & $\mathrm{X}$ & & & & & & & 13 \\
\hline & Melanoderma & & & & $\mathrm{X}$ & & & & 2 \\
\hline & Xantoderma & & & & & & & & 6 \\
\hline & Não informa & & $\mathrm{X}$ & $\mathrm{X}$ & & $\mathrm{X}$ & $\mathrm{X}$ & $\mathrm{X}$ & 22 \\
\hline \multirow{3}{*}{ Gênero } & Masculino & $\mathrm{X}$ & $\mathrm{X}$ & $\mathrm{X}$ & & & $\mathrm{X}$ & & 22 \\
\hline & Feminino & & & & $\mathrm{X}$ & $\mathrm{X}$ & & & 20 \\
\hline & Não informa & & & & & & & $\mathrm{X}$ & 5 \\
\hline \multirow{2}{*}{ Sulco } & Palatogengival & $\mathrm{X}$ & $\mathrm{X}$ & $\mathrm{X}$ & $\mathrm{X}$ & $\mathrm{X}$ & $\mathrm{X}$ & $\mathrm{X}$ & 47 \\
\hline & Vestibular Vertical & & & & & & & & 1 \\
\hline \multirow{6}{*}{$\begin{array}{l}\text { Dente } \\
\text { Afetado }\end{array}$} & 12 & & $\mathrm{X}$ & & & & $\mathrm{X}$ & & 16 \\
\hline & 22 & $\mathrm{X}$ & & $\mathrm{X}$ & & & & & 17 \\
\hline & 12 e 22 & & & & $\mathrm{X}$ & & & & 7 \\
\hline & 11 & & & & & $X$ & & & 2 \\
\hline & 21 & & & & & & & $\mathrm{X}$ & 4 \\
\hline & 11 e 21 & & & & & & & & 1 \\
\hline \multirow{4}{*}{$\begin{array}{l}\text { Sintomas } \\
\text { Clínicos }\end{array}$} & Ausente & $\mathrm{X}$ & & & $\mathrm{X}$ & & & & 16 \\
\hline & Dor & & $\mathrm{X}$ & & & $\mathrm{X}$ & $\mathrm{X}$ & $\mathrm{X}$ & 24 \\
\hline & Edema & & & $\mathrm{X}$ & & $\mathrm{X}$ & $\mathrm{X}$ & $\mathrm{X}$ & 17 \\
\hline & Pustulação & & & & & & & & 7 \\
\hline \multirow{4}{*}{ Pulpopatia } & Ausente & & & $\mathrm{X}$ & $\mathrm{X}$ & $\mathrm{X}$ & $\mathrm{X}$ & & 19 \\
\hline & Necrose pulpar & $\mathrm{X}$ & $\mathrm{X}$ & & & & & $\mathrm{X}$ & 22 \\
\hline & Outras & & & & & & & & 2 \\
\hline & Não informa & & & & & & & & 6 \\
\hline \multirow{4}{*}{ Higiene bucal } & Boa & & & & & & & & 3 \\
\hline & Regular & & & & & & & & 0 \\
\hline & Ruim & $\mathrm{X}$ & & & & & & & 3 \\
\hline & Não fala & & $\mathrm{X}$ & $\mathrm{X}$ & $\mathrm{X}$ & $\mathrm{X}$ & $\mathrm{X}$ & $\mathrm{X}$ & 41 \\
\hline \multirow{3}{*}{ Periodontopatia } & Presente & $\mathrm{X}$ & $\mathrm{X}$ & $\mathrm{X}$ & $X$ & $x$ & $\mathrm{X}$ & $x$ & 39 \\
\hline & Ausente & & & & & & & & 3 \\
\hline & Não informa & & & & & & & & 5 \\
\hline \multirow{8}{*}{ Tratamento } & RAR & & & & $\mathrm{X}$ & $\mathrm{X}$ & & & 10 \\
\hline & Endodontia & & $\mathrm{X}$ & & & & & $\mathrm{X}$ & 12 \\
\hline & Endo/ RAR & & & & & & & & 10 \\
\hline & Odontoplastia & & & $\mathrm{X}$ & $\mathrm{X}$ & & $\mathrm{X}$ & & 13 \\
\hline & Dentística & & & & & $\mathrm{X}$ & & & 5 \\
\hline & Cir. Par.ou Perio. & & & $\mathrm{X}$ & $\mathrm{X}$ & & $\mathrm{X}$ & & 22 \\
\hline & Exodontia & $\mathrm{X}$ & $\mathrm{X}$ & & & & & $\mathrm{X}$ & 18 \\
\hline & Prevenção & & & & & & & & 2 \\
\hline \multirow{2}{*}{ Acompanhamento } & Sim & & & $\mathrm{X}$ & $\mathrm{X}$ & $\mathrm{X}$ & $\mathrm{X}$ & $\mathrm{X}$ & 32 \\
\hline & Não & $\mathrm{X}$ & $\mathrm{X}$ & & & & & & 15 \\
\hline \multirow{4}{*}{ Sucesso } & Sim & & & $\mathrm{X}$ & $\mathrm{X}$ & $\mathrm{X}$ & $\mathrm{X}$ & & 24 \\
\hline & Não & $\mathrm{X}$ & $\mathrm{X}$ & & & & & $\mathrm{X}$ & 20 \\
\hline & Parcial & & & & & & & & 1 \\
\hline & Não informa & & & & & & & & 2 \\
\hline \multirow{3}{*}{ Radiografias } & Antes & $\mathrm{X}$ & $\mathrm{X}$ & $\mathrm{X}$ & $\mathrm{X}$ & & & $\mathrm{X}$ & 38 \\
\hline & Depois & & & $\mathrm{X}$ & $\mathrm{X}$ & & & & 18 \\
\hline & Não informa & & & & & $\mathrm{X}$ & $\mathrm{X}$ & & 9 \\
\hline & Antes & & 7 & & $4-6$ & 5 & 9 & 7 & de 2 à 12 \\
\hline Bolsa em mm & Depois & & & & & 1 & & 8 & de 1 à 8 \\
\hline & Não relata & $\mathrm{X}$ & & $\mathrm{X}$ & & & & & 8 \\
\hline & Dente invaginado & & & & & & & & 1 \\
\hline Outras Alterações & Raiz acessória & & & & & & & & 8 \\
\hline & Cúspide em garra & & & & & & & & 2 \\
\hline
\end{tabular}




\subsection{Das metodologias empregadas para a realização deste trabalho}

\subsubsection{Da análise epidemiológica}

Poucos estudos foram direcionados para a identificação de dados epidemiológicos que correlacionem $\circ$ sulco palatogengival com sua etiopatogenia, prevalência populacional, relação com a necessidade de tratamento periodontal, endodôntico ou restaurador, e até mesmo sua freqüência entre os incisivos centrais e laterais superiores.

O primeiro estudo de freqüência do sulco palatogengival foi realizada em 625 incisivos laterais superiores extraídos hígidos ou quase hígidos por EVERETT; KRAMER ${ }^{48}$, em 1972. Neste estudo, os dentes foram fervidos com fluidos maceratórios, desengordurados, lavados, secos e raspados, caso apresentassem cálculo aderido. Nenhum critério diagnóstico foi estabelecido para a seleção dos dentes com sulco palatogengival neste trabalho, porém, foram relatados 12 dentes com sulcos rasos que iniciavam como sulcos coronários se estendendo pela raiz sem alcançar o ápice, três dentes com sulcos profundos que não se estendiam até o ápice e outros três dentes com sulcos profundos que se estendiam quase até o ápice.

Para de estabelecer uma relação entre o sulco palatogengival e a doença periodontal localizada, WITHERS et al. ${ }^{146}$ (1981), estudaram 531 recrutas das Forças Armadas Norte-americanas com idades entre 17-35 anos. O critério diagnóstico utilizado para a identificação do sulco palatogengival foi a extensão apical a partir da junção amelocementária. Foram aferidos a idade, o gênero e a raça de cada indivíduo. Mediram ainda o grau de mobilidade dos dentes, bem como o índice de placa, o índice gengival e o índice de doença periodontal na face palatina dos incisivos superiores através de escores. Aplicou-se o teste do qui-quadrado para a hipótese de que não havia diferença estatística entre os vários grupos considerados. Nesta amostra foram encontrados 45 indivíduos com sulco palatogengival (8,5\%), dos 2.099 incisivos superiores avaliados somente 49 apresentavam o sulco (2,33\%). A prevalência 
nos incisivos laterais foi de $4,4 \%$, nos centrais de $0,28 \%$, sendo bilateral em $0,75 \%$ (quatro pacientes). Os incisivos laterais superiores foram maioria entre os dentes acometidos pelo sulco $(93,8 \%)$ e os incisivos centrais superiores foram $6,2 \%$. Foram encontradas diferenças significantes estatisticamente na comparação entre portadores e não portadores do sulco nas variáveis índice de placa $(2: 1,32)$, índice gengival $(2,13: 1,37)$ e no índice de doença periodontal $(2,88: 1,51)$. O grau de mobilidade, o gênero e a raça não apresentaram diferenças significantes estatisticamente.

Em uma amostra de 3168 incisivos superiores extraídos, composta por 1786 incisivos laterais e 1382 incisivos centrais, KOGON ${ }^{75}$, em 1986, se propôs a avaliar a prevalência, a localização e a conformidade do sulco palatogengival. Não foi mencionado o critério diagnóstico para a identificação do sulco palatogengival, porém, parece que foram considerados como sulcos palatogengivais alguns casos que não havia a progressão apical além da junção amelocementária, pois foi informado que quando 0 defeito ultrapassasse a junção amelocementária, a distância de extensão do sulco seria aferida a partir da junção. Os dentes da amostra identificados com sulco palatogengival foram caracterizados quanto à localização do sulco, origem e término. Os critérios de conformidade foram raso, profundo ou tubo fechado. Avaliou-se ainda qualquer alteração na junção ou no esmalte presentes na região do sulco.

A prevalência do sulco palatogengival no trabalho de KOGON ${ }^{75}$ foi de $4,6 \%$ da amostra (147 dentes), sendo 5,6\% entre os incisivos laterais (100 dentes) e 3,4\% dos incisivos centrais (47 dentes). A conformação dos sulcos dos dentes avaliados foi de 54\% considerado raso, $42 \%$ como depressão profunda e $4 \%$ como tubo fechado. A junção amelocementária apresentou degrau em $38 \%$ dos incisivos laterais e 35\% dos incisivos centrais. Entre os incisivos laterais com sulco palatogengival a localização dos sulcos foi de $13 \%$ na face mesial, $25 \%$ na distal e $62 \%$ na face mesiopalatal. Nos centrais $38 \%$ dos sulcos apresentavam-se localizados na face mesial, $17 \%$ na distal e $45 \%$ na mesiopalatal. Quanto à origem do sulco nos incisivos laterais $15 \%$ iniciavam na face lingual, $77 \%$ no cíngulo, $7 \%$ na junção amelocementária e $1 \%$ na raiz. 
Nos incisivos centrais, $11 \%$ dos dentes com sulco palatogengival tinha o sulco originando na face lingual, $74 \%$ no cíngulo, $13 \%$ na junção amelocementária e $2 \%$ na raiz. O término do sulco palatogengival nos incisivos laterais foi de $9 \%$ no cíngulo, $44 \%$ na junção amelocementária e $47 \%$ na raiz. Entre os incisivos centrais também $9 \%$ dos sulcos terminavam no cíngulo, $21 \%$ na junção e $70 \%$ na raiz. A extensão do sulco quando terminava na raiz nos incisivos laterais foi de $43 \%$ entre $1-5 \mathrm{~mm}, 47 \%$ de $6-10 \mathrm{~mm}$ e $10 \%>10 \mathrm{~mm}$. A mesma medida realizada nos incisivos centrais, demonstrou $39 \%$ dos sulcos terminando de 1 $5 \mathrm{~mm}$ além da junção amelocementária, $37 \%$ entre $6-10 \mathrm{~mm}$ e $24 \%>10 \mathrm{~mm}$.

A maior amostra de pacientes para avaliar-se a freqüência do sulco palatogengival envolveu 1.081 homens, de idades entre 20-22 anos, comparando-os com um outro grupo de 634 pacientes com doença periodontal e com idades entre 35-50 anos. Neste estudo, desenvolvido por BAĈIĆ et al. ${ }^{13}$ em 1990, mediram a profundidade de bolsa, gengivite e índice de placa dos pacientes que apresentavam sulco palatogengival, juntamente com o registro radiográfico periapical. A localização do sulco palatogengival também foi registrada como: distal; mesiopalatina e mesial. O critério diagnóstico utilizado para a seleção dos casos foi a extensão apical além da junção amelocementária. A comparação estatística foi baseada no teste de dois grupos pareados de Wilcoxon. Na amostra de homens, 11 pacientes $(1,01 \%)$ apresentaram o sulco palatogengival em 15 incisivos e entre os pacientes com doença periodontal apenas em 5 incisivos $(0,79 \% \mathrm{n}=634)$ foram diagnosticados como portadores. A profundidade de bolsa no local do sulco palatogengival foi substancialmente maior na comparação dos dentes com e sem o sulco, tanto no grupo dos homens $(3,8: 1,2 \mathrm{~mm})$ quanto nos pacientes com doença periodontal $(8,8: 4 \mathrm{~mm})$. As relações entre gengivite e índice de placa dos pacientes avaliados não foram mencionadas nos resultados do estudo.

No Brasil dois trabalhos epidemiológicos foram desenvolvidos por PÉCORA et al. em $1991{ }^{105}$ e por PÉCORA; CRUZ FILHO ${ }^{104}$ em 1992. O primeiro utilizou uma amostra de 500 incisivos centrais superiores e 421 incisivos laterais superiores extraídos. Nenhum critério diagnóstico foi estabelecido para a seleção dos dentes, porém, foram encontrados 10 incisivos 
centrais superiores com sulco (2\%) e em 2,6\% dos incisivos laterais superiores, ou seja, por volta de 11 dentes, porém este dado não é oferecido no artigo. 0 trabalho publicado em 1992 baseou-se no exame de 642 pacientes identificando-os por idade, que variou entre 7-68 anos, gênero e cor da pele (163 homens brancos, 272 mulheres brancas, 104 homens negros e 103 mulheres negras). O critério diagnóstico empregado para a identificação do sulco foi sua extensão apical do sulco além da junção amelocementária; também foi registrada a presença ou ausência de bolsa periodontal. Foram encontrados 25 dentes com o sulco, 3,9\% da amostra, 6 destes em incisivos centrais superiores e 19 em incisivos laterais superiores. A prevalência relativa à raça foi de $3,4 \%$ nos brancos e de $4,8 \%$ nos negros. O teste não paramétrico de comparação de vários grupos de Fisher foi aplicado e não mostrou diferença estatística significante na relação entre o gênero e a raça, nem entre o grupo dentário e a raça.

A maior prevalência do sulco palatogengival foi relatada por HOU et al. ${ }^{67}$ (1993), com 44,6\% de pacientes portadores. Foram estudo, analisados 101 pacientes chineses, e o critério de inclusão do paciente, foi a presença dos quatro incisivos superiores, portanto a amostra constituiu-se de 404 incisivos superiores. O critério diagnóstico para a identificação do sulco palatogengival, foi que o sulco se estendesse apicalmente até ou além da junção amelocementária. Foram registrados: a profundidade de bolsa; radiografia e cirurgia periodontal caso houvesse necessidade. A idade, o gênero, além das medidas por escores do índice de placa, índice gengival também foram computadas. Utilizou-se teste proporcional para determinar a prevalência do sulco entre os gêneros, teste do qui-quadrado para comparar a localização do sulco (mesial, mediopalatal e distal), e a relação entre a saúde periodontal e a presença do sulco medidas através dos índices gengivais e de placa foram comparados com o teste $\mathrm{t}$. Os resultados não demonstraram diferença significante entre homens (20,3\% dos dentes com sulco palatogengival) e mulheres $(14,1 \%$ dos dentes com sulco palatogengival) sendo que a prevalência do sulco foi de $45,3 \%$ nos homens e $43,2 \%$ nas mulheres. Os incisivos laterais superiores representaram $30,2 \%$, os centrais $5,9 \%$ e a manifestação bilateral do sulco foi observada em $4 \%$ dos dentes com sulco 
palatogengival. Quanto à relação do sulco palatogengival e doença periodontal os autores encontraram $26 \%$ de dentes com sulco e doença periodontal, porém esta ocorrência foi similar nas localizações mesial, mediopalatal e distal. Os índices gengivais mostraram-se diferentes estatisticamente nos incisivos laterais esquerdos e direitos com sulco palatogengival $(1,1$ e 1,15) comparados aos sem sulco $(0,49$ e 0,42$)$. Da mesma forma os índices de placa foram mais altos em dentes com o sulco palatogengival comparados àqueles sem o sulco.

Tabela 2 - Distribuição dos achados epidemiológicos de freqüência do sulco palatogengival

\begin{tabular}{l|ccc}
\multicolumn{1}{c|}{ Casuísticas } & número de & número de & Prevalência \\
& pacientes & dentes & \\
\hline BAČIĆ et al. ${ }^{13}$ & 1081 & - & $1,01 \%$ \\
EVERETT; KRAMER ${ }^{48}$ & - & 625 & $2,88 \%$ \\
HOU; TSAI ${ }^{17}$ & 101 & - & $44,6 \%$ \\
KOGON ${ }^{75}$ & - & 3168 & $4,6 \%$ \\
PÉCORA; CRUZ FILHO & - & 921 & $2-2,6 \%$ \\
PÉCORA et al. ${ }^{105}$ & 642 & - & $3,9 \%$ \\
WITHERS et al. ${ }^{146}$ & 531 & - & $8,5 \%$ \\
\hline
\end{tabular}




\subsubsection{Da análise morfológica dos dentes portadores do sulco palatogengival}

O primeiro estudo para abordar as características microscópicas do sulco palatogengival foi realizado por LEE, LEE e POON ${ }^{82}$ em 1968. Neste estudo os não menciona-se a quantidade de espécimes avaliados através de microscopia óptica de secções descalcificadas e coradas com hematoxilina e eosina, porém seus relatos morfológicos se tornaram referência para outros estudos. Foram observados fatores como: mistura de cemento celular e acelular na base do sulco; quantidade variável de cemento existente no sulco; presença de reabsorção radicular na base e nas laterais do sulco, com exposição de túbulos dentinários; presença de placa dentobacteriana no leito do sulco e vitalidade pulpar dos espécimes.

Os critérios para análise morfológica desenvolvidos nesta dissertação utilizaram métodos e critérios preestabelecidos por trabalhos desenvolvidos anteriormente na disciplina de Patologia Bucal da FOB-USP e em um único trabalho que avaliou sistematicamente uma amostra de dentes com sulco palatogengival à microscopia eletrônica de varredura realizado por GAO et al. ${ }^{53}$ em 1989.

O estudo que iniciou o entendimento da morfologia dos incisivos superiores portadores do sulco palatogengival foi desenvolvido por LARA em $1993^{79}$ em dissertação de mestrado e em seguida por LARA; CONSOLARO e BRUCE ${ }^{80}$, em 2000. Analisou-se macro e microscopicamente a morfologia de 13 incisivos permanentes superiores portadores do sulco palatogengival. Secções transversais dos dentes foram desgastadas manualmente e obtiveram-se cortes microscópicos de 60 a 90um. A observação microscópica foi realizada por microscopia de luz, considerando-se cada tecido dentinário individualmente, bem como as alterações do contorno da superfície radicular e do espaço pulpar. Seus achados mostraram que o sulco palatogengival apresentou-se mais freqüente nos incisivos laterais superiores. Notou-se deformação do contorno da cavidade pulpar subjacente ao sulco, juntamente 
com uma diminuição da espessura do esmalte e dentina além de aumento da espessura cementária. Observou-se a extensão apical do sulco em nove espécimes e a comunicação da cavidade pulpar com o compartimento periodontal em apenas um caso (Figura 2).
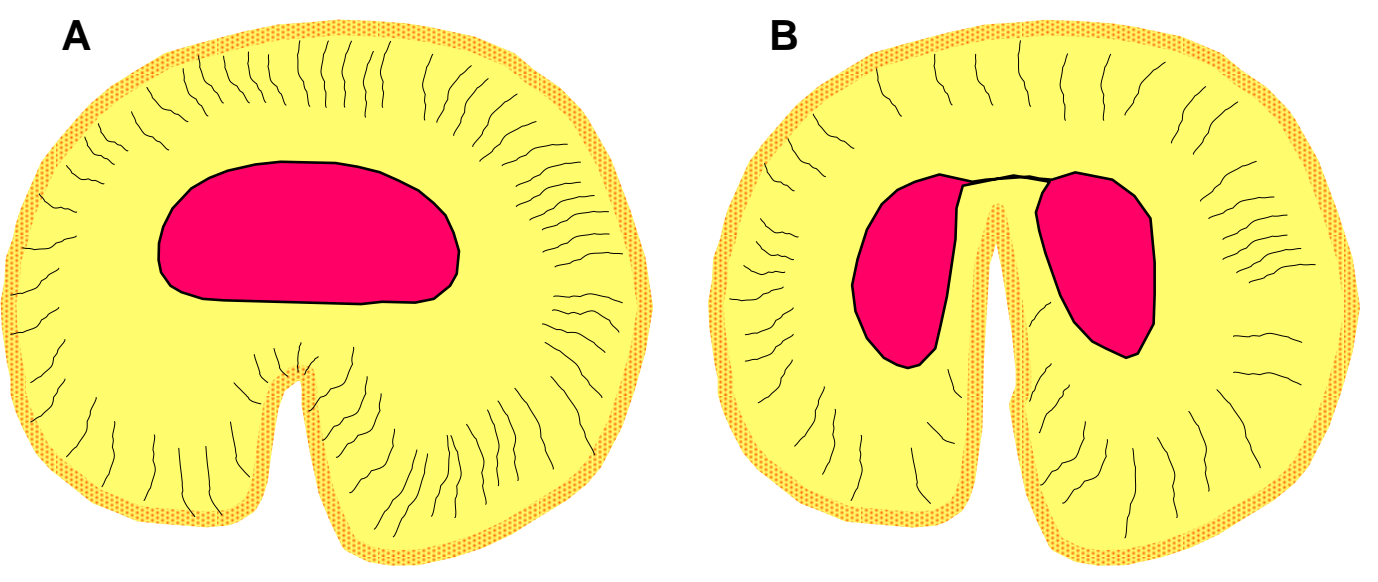

\section{C}

Figura 2 - Representação esquemática a partir das alterações na morfologia do contorno da cavidade pulpar e a relação da polpa, dentina e cemento com a superfície externa em dentes com sulco palatogengival, baseado na amostra de LARA, CONSOLARO e BRUCE, $2000^{80}$

A observação do sulco palatogengival à microscopia eletrônica de varredura, realizada por GAO et al. ${ }^{53}$, em 1989, proporcionou a observação de foraminas acessórias não só no leito do sulco, mas também na parede interna da cavidade pulpar e em secções transversais. Foram avaliados 14 incisivos laterais superiores, 10 deles cortados longitudinalmente no sentido vestibulolingual; um incisivo que possuía raiz acessória também foi cortado longitudinalmente, porém com uma secção paralela as raízes principal e acessória; os outros três dentes foram fraturados transversalmente no nível da junção amelocementária. Os autores ressaltam que a maioria das lesões combinadas em dentes portadores do sulco palatogengival é tratada com 
sucesso, pois somente alguns casos vão apresentar comunicações entre a polpa e o periodonto.

A análise dos espécimes à microscopia eletrônica de varredura, e o devido preparo dos mesmos para esta análise seguiram os procedimentos descritos nos trabalhos de NEUVALD ${ }^{96}$, NEUVALD; CONSOLARO ${ }^{97} \mathrm{e}$ GODOY 55 .

\subsubsection{Da análise da morfologia dos canais antes e depois do preparo biomecânico}

Nenhum estudo propôs-se a avaliar os desafios do tratamento endodôntico de dentes portadores do sulco palatogengival. Este estudo baseou-se nas metodologias empregadas para a avaliação das alterações na morfologia dos canais radiculares, causadas pelo preparo biomecânico.

O método de análise da instrumentação dos canais radiculares proposto por BORGES ${ }^{21}$ (1985), e por BRAMANTE et al. ${ }^{25}$ (1987) consiste na observação comparativa de secções transversais de dentes antes e depois do preparo biomecânico. Para tanto, os autores incluíram os dentes a serem analisados em um tronco de pirâmide de resina acrílica quimicamente ativada incolor. Já com o dente incluído, confeccionaram sulcos paralelos transversais em três faces da estrutura de resina, e sulcos paralelos longitudinais na quarta face. Uma mufla de gesso foi confeccionada para o conjunto dente-resina. Os blocos de resina foram seccionados transversalmente no terço cervical, no terço médio e no terço apical. Cada secção transversal foi fotografada, a forma e a área do canal foram medidas. As secções transversais novamente eram posicionadas dentro da mufla, que estabilizava os fragmentos durante a instrumentação. Após instrumentados, cada fragmento foi fotografado novamente para a comparação da forma e a área dos canais. Este método mostrou-se simples e fácil de reproduzir, com ótima precisão para a avaliação comparativa de técnicas de instrumentação e da alteração da morfologia do canal com o preparo biomecânico. 
Outros métodos semelhantes foram apresentados sugerindo modificações, adaptações ou simplificações do método descrito por BRAMANTE et al. ${ }^{25}$. McCANN et al. ${ }^{86}$ (1990) substituíram a mufla de gesso por um molde de ferro, com o intuito de facilitar os procedimentos laboratoriais tornando-os mais rápidos, porém este modelo necessita a utilização de uma morsa para conter o conjunto, e demanda a confecção do molde metálico. TAMSE; PILO ${ }^{133}$ (1998) propuseram a eliminação da mufla de gesso pela utilização de quatro pinos metálicos inseridos no bloco de resina que permaneceria num molde único de teflon para todos os espécimes avaliados. SKELTON-MACEDO, CARDOSO e BOMBANA ${ }^{128}$ (1999) eliminaram a utilização da mufla, através da inserção de pinos de aço lubrificados em resina de poliéster de cura lenta. Ainda sugeriram a pintura da superfície radicular com tinta nanquim, para a melhor visualização da circunferência da superfície radicular. Apesar do conjunto dos fragmentos cortados permanecerem estáveis, não foi explicado como seria mantida a distância perdida pelos cortes transversais, já que os pinos demonstrados eram cilíndricos e lisos.

O conceito de blocos de resina fotopolimerizáveis aderidas às raízes por ataque ácido, confecção de muflas de resina quimicamente ativada invés de gesso, e sulcos em "V" nas quatro faces dos blocos previamente à confecção das muflas, foi introduzido por ZAIA et al. ${ }^{149}$ (2000). Com a finalidade de não perder estrutura dentária, com os cortes normalmente realizados por discos diamantados, propuseram a fratura dos blocos com uma chave de fenda inserida em sulcos transversais confeccionados nos blocos e na dentina subjacente, que enfraqueceriam a estrutura radicular sem seccionar a raiz.

Com o objetivo de comparar a capacidade de remoção da camada interna dentinária de canais ovais por duas técnicas de instrumentação manuais, força balanceada e limagem circunferente, WU et al. ${ }^{147}$ (2003) modificou a técnica de BRAMANTE et al. ${ }^{25}$ confeccionando as muflas com guias metálicas, observando e fotografando as secções através de estereomicroscópio. A análise comparativa do perímetro e da forma do canal foi feita através de um software (KS 1000 imaging system 3.0 - Carl Ziess 
Vison) utilizando as imagens digitalizadas. Os autores observaram neste estudo, que ambas as técnicas não apresentam diferenças significantes estatisticamente, e ainda que grandes porções das paredes dos canais radiculares permaneceram sem serem instrumentadas.

Para avaliar a ação do preparo do canal radicular de pré-molares superiores com sulco do desenvolvimento radicular CARAM; BIFFI ${ }^{30}$ (2005) mediram as áreas dos canais radiculares das raízes vestibulares e palatinas após a instrumentação endodôntica, e as espessuras de dentina radicular na região do sulco, mais cinco mensurações aleatórias de outras regiões. Neste estudo optaram por estudar dois grupos separados de dentes, um instrumentado com 20 dentes e outro com seis dentes sem instrumentação. A análise quantitativa foi realizada com auxilio de um software (HL ++ Image Western Vision Software) utilizando fotografias das secções transversais correspondentes ao terço médio das raízes avaliadas. Não foi padronizado o aumento da observação, porém, segundo os autores, as imagens foram calibradas em milímetro. Os autores encontraram medidas de áreas semelhantes comparando os canais vestibulares e palatinos, e reportaram que após a instrumentação endodôntica, as espessuras radiculares de dentina na região do sulco foram menores que as demais medidas. Além dos achados, foi proposto que quando necessário a preparação de pinos nestas raízes, deveria ser conservado no interior destes canais, no mínimo $7 \mathrm{~mm}$ de guta-percha a fim de minimizar a possibilidade de fraturas cervicais.

Outros métodos de análise de técnicas de instrumentação, qualidade do preparo biomecânico, da espessura de dentina das paredes dos canais, da área do canal e de outras distâncias relevantes como os perímetros da raiz, e do canal radicular ${ }^{147}$ variam entre: análise radiográfica 20, 47; através de imagens de cortes em microscopia óptica 62, 143; a partir da microscopia eletrônica de varredura ${ }^{22}$; e mesmo através da injeção intracanal de silicone ${ }^{41}$. 
PROPOSIÇ $\tilde{\mathcal{A} O}$ 


\section{PROPOSIÇÃO}

Os objetivos deste trabalho são:

\section{Parte A:}

a) Detectar a freqüência do sulco palatogengival nos incisivos superiores em uma população com assistência odontológica gratuita de 500 pessoas;

b) Correlacionar a ocorrência do sulco palatogengival nos incisivos superiores com o tipo facial, a relação entre os arcos, os tipos de arco dentário e a história familiar;

c) Abordar aspectos terapêuticos nos pacientes da amostra que apresentem alguma alteração relacionada ao sulco palatogengival e sugerir manobras para os profissionais atuarem mais efetivamente nesses casos;

d) Comparar os dados obtidos com os apresentados por trabalhos semelhantes da literatura e os dados antropológicos descritos na literatura com a etiopatogenia da doença. 


\section{Parte B:}

a) Analisar em incisivos superiores com o sulco palatogengival sua morfologia macroscópica e microscópica da superfície radicular e dos canais radiculares, verificando a presença de comunicações entre o interior do canal e o meio externo através do sulco palatogengival, para entender as dificuldades do tratamento e o prognóstico de casos semelhantes;

b) Detectar as alterações morfológicas produzidas pelo preparo biomecânico dos canais radiculares desses dentes, relacionando os aspectos morfológicos com os meios de diagnóstico e formas de tratamento descritas na literatura.

c) Identificar a possível presença de nichos onde microorganismos que infectam o sulco possam se estabelecer, causando danos periodontais e endodônticos. 
$\mathcal{M} \mathcal{A} \mathcal{T} \mathcal{E} I \mathcal{A L} \mathcal{E} \mathcal{M} \dot{\mathcal{T}} O D O S$ 


\section{MATERIAL E MÉTODOS}

\subsection{Parte A: Avaliação da freqüência do sulco palatogengival}

\subsubsection{Amostragem}

Realizou-se a detecção da freqüência do sulco palatogengival em uma população odontologicamente assistida nas clínicas da Faculdade de Odontologia de Bauru durante um período de nove meses de março de 2004 a outubro de 2005. A amostragem teve como base as informações obtidas através dos exames clínico e radiográfico. Foi obtida uma amostra de 500 pacientes.

Para o registro manual dos dados gerais dos pacientes uma ficha foi utilizada com um "check-list" contendo as seguintes características: nome; endereço; gênero; cor da pele; presença do sulco palatogengival; profundidade de bolsa dos portadores do sulco; tipo facial; relação entre os arcos; tipos de arco dentário e história familiar (Figura 3). Juntamente com a ficha acompanhou o termo de consentimento livre e esclarecido e a carta de informação ao paciente seguindo a resolução $n^{\circ} 196$ do Conselho Nacional de Saúde (anexo 1, 2 e 3). Os pacientes analisados estavam em tratamento odontológico e se beneficiaram do diagnóstico, pois houve a conscientização quanto à prevenção de futuras conseqüências deletérias decorrentes do sulco palatogengival e a prevenção pela orientação de cuidados com a higienização do dente envolvido. 


\section{FIGURA 3}

Figura 3A - Características do individuo com tipo facial dolicocéfalo de acordo com ENLOW ${ }^{44}$ E GRAY ${ }^{59}$. A aparência longilínea, estreita e longa, da face é decorrente do tamanho reduzido da base do crânio, juntamente com o posicionamento mais anterior do côndilo da mandíbula e mento retraído. A distância inter-orbital é pequena e os malares pouco pronunciados. O nariz é longo de aspecto romano ou aquilino, a boca possui o lábio inferior maior que o superior. O perfil do indivíduo tende a ser convexo

Figura 3B - Características do individuo com tipo facial braquicéfalo de acordo com ENLOW ${ }^{44}$ E GRAY ${ }^{59}$. Estes indivíduos possuem a face curta e larga, a sua estrutura óssea caracterizada por: base do crânio larga; mandíbula retruída e mento proeminente fazendo com que os lábios quase não apareçam. A distância inter-orbital é ampla, com malares pronunciados e nariz largo, semelhante ao de um lutador de boxe. O perfil deste indivíduo tende a ser côncavo

Figura 3C - Características do individuo com tipo facial mesocéfalo de acordo com ENLOW ${ }^{44}$ E GRAY $^{59}$. A aparente proporcionalidade encontrada neste indivíduo é resultante dos tamanhos ósseos intermediários. A disposição óssea propicia um perfil reto com nariz longo, mas com ápice elevado. Ambos os lábios ficam a mostra neste indivíduo com o lábio inferior ligeiramente maior que o superior

Figura 3D - Relação entre os arcos proposta por ANGLE ${ }^{6}$. Tal classificação baseia-se na relação entre os primeiros molares superiores e inferiores levando em conta o posicionamento dos caninos e a posição da mandíbula. Na classe 1, a mandíbula e o arco dentário à ela superposto, estão em correta relação mesiodistal com a maxila e demais ossos da face. A cúspide mesiovestibular do primeiro molar superior oclui no sulco central do primeiro molar inferior. A classe 2 apresenta a arcada inferior em relação distal com a arcada superior. A cúspide mesiovestibular do primeiro molar superior oclui no espaço entre a cúspide vestibular do primeiro molar inferior e a face distal da cúspide vestibular do segundo pré-molar inferior, é subdividida em $1^{\circ}$ e $2^{\circ}$ subdivisão relacionada ao posicionamento dos dentes anteriores. A classe 3 tem o primeiro molar inferior em posição mesial na relação com o primeiro molar superior. A cúspide mesiovestibular do primeiro molar superior oclui no espaço entre a cúspide distal do primeiro molar inferior e a cúspide mesiovestibular do segundo molar inferior

Figura 3E - Forma dos arcos dentários simplificado a partir de CHIRINOS ${ }^{32}$. Três formas de arco dentário foram relevadas: ovalada com relativa curvatura anterior; triangular apresenta angulação nos incisivos centrais; quadrada quando a porção anterior é quase reta e as porções posteriores paralelas entre si 


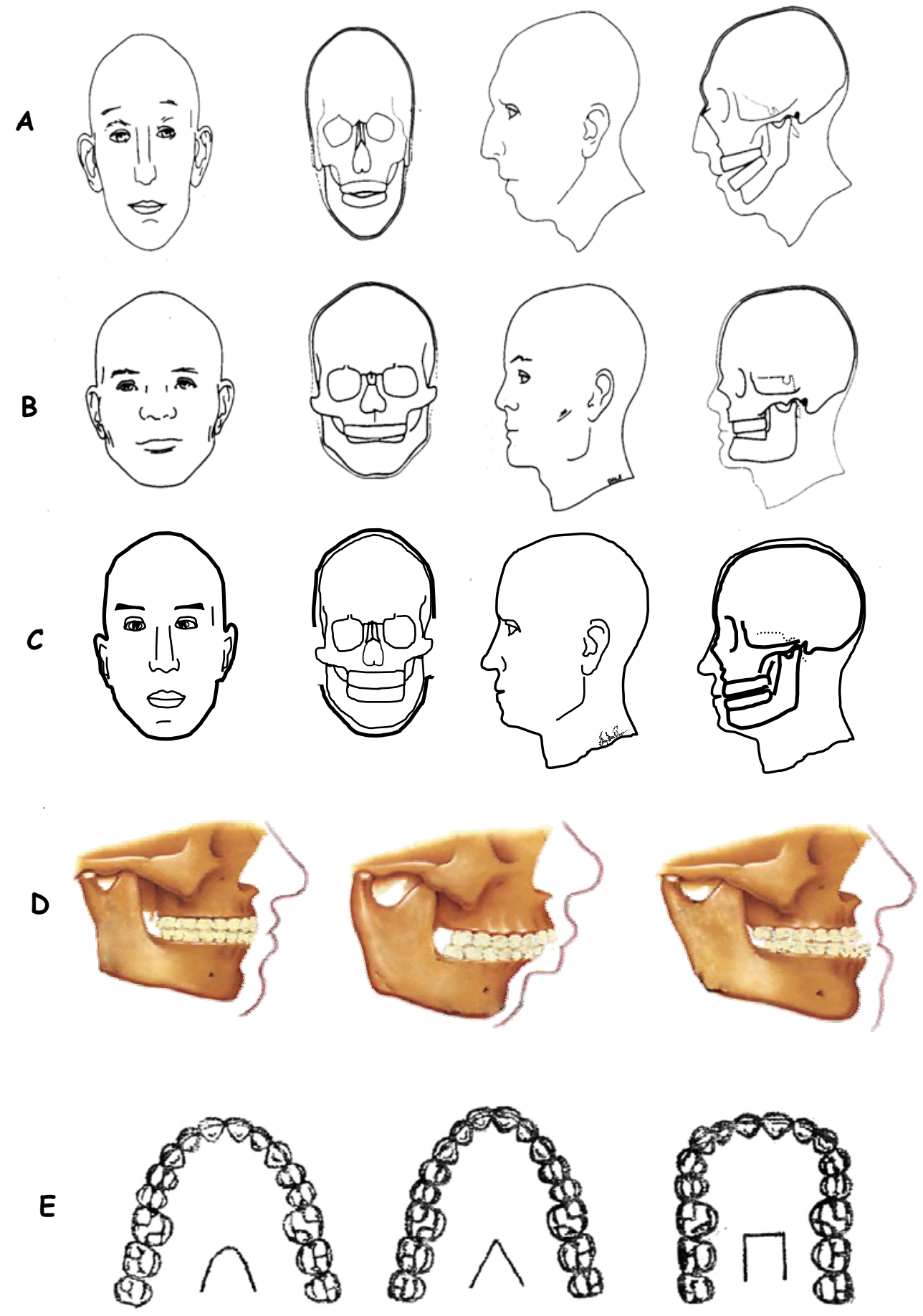




\subsubsection{Análise dos resultados da parte $A$}

Os dados obtidos foram tabulados para análise estatística comparativa. Assim, os achados epidemiológicos foram analisados e correlacionados.

\subsection{Parte B: Avaliação da morfologia dos canais e alterações morfológicas após o preparo biomecânico de dentes portadores do sulco palatogengival.}

\subsubsection{Amostra}

$\mathrm{Na}$ coleção de espécimes dentários foram identificados e selecionados 20 incisivos superiores portadores do sulco palatogengival. Os dentes foram registrados e armazenados. Antes do armazenamento, os resíduos e restos de tecidos gengivais, periodontais, ósseos ou periapicais foram eliminados a partir de banhos em hipoclorito de sódio a 1\%. Raspagens não foram utilizadas para preservar as superfícies dos espécimes.

A seleção foi realizada a partir do exame macroscópico do sulco palatogengival, ou seja, da detecção de uma invaginação linear que se iniciava na região do cíngulo, estendendo-se apicalmente pela superfície radicular palatina além da junção amelocementária, por distâncias variáveis, nos incisivos superiores permanentes.

\subsubsection{Exame macroscópico}

Os dentes selecionados foram analisados macroscopicamente quanto à: morfologia, local de início e do término do sulco na coroa, extensão, 
profundidade, bem como associação com outras anomalias, displasias e deformidades dentárias. Assim os sulcos foram analisados e classificados:

a) Quanto à morfologia e profundidade:

> Depressão: quando a alteração for extremamente rasa e sua porção mais profunda não for delineável como um risco;

> Sulco ou ruga: quando o seu término mais profundo for delineável como um rico. Neste caso a profundidade será considerada moderada;

> Fissura: quando não for possível delinear com um risco a sua porção mais profunda, sendo considerado de profundidade severa.

b) Quanto ao local de início na coroa, foi detectado o exato acidente anatômico onde se inicia o sulco palatogengival, considerando-se:

$>$ Fossa lingual;

$>$ Cíngulo em sua crista mesial;

> Cíngulo em sua crista distal;

$>$ Cíngulo em sua parte central.

c) Quanto à sua extensão além da junção amelocementária, se o sulco tem o término no terço cervical, médio ou apical da raiz.

d) Quanto à sua localização: mesial; distal; vestibular ou palatino. Indicando o trajeto percorrido pelo sulco palatogengival no dente. 
e) Quanto ao trajeto da junção amelocementária. A junção foi analisada quanto a sua regularidade e continuidade no trajeto circunferencial do dente, com ou sem a formação de um degrau neste trajeto;

f) Associação com outras anomalias, displasias e deformidades dentárias, especialmente quanto à presença de dente invaginado, cúspide em garra, dilaceração radicular, raiz supranumerária, hipoplasias do esmalte, projeções cervicais do esmalte, etc.

g) Outras associações: alguns aspectos também foram registrados como a presença de cárie dentária, cálculos dentários, fraturas, desgaste, hipercementose, reabsorção radicular, etc.

\subsubsection{Exame estereomicroscópico}

Os dentes foram submetidos à análise estereomicroscópica (Carl Zeiss) com a finalidade de confirmar os dados da avaliação anterior, mas com mais precisão e rigor quanto à morfologia do sulco palatogengival. Essa observação seguiu os mesmos critérios do exame macroscópico, com o aumento da imagem em 40 a 100 vezes. Nesta análise, avaliaram-se ainda as características das superfícies cementárias e adamantinas nas paredes do sulco palatogengival como áreas de reabsorção, hipoplasias do esmalte e contorno da junção esmalte-cemento. 


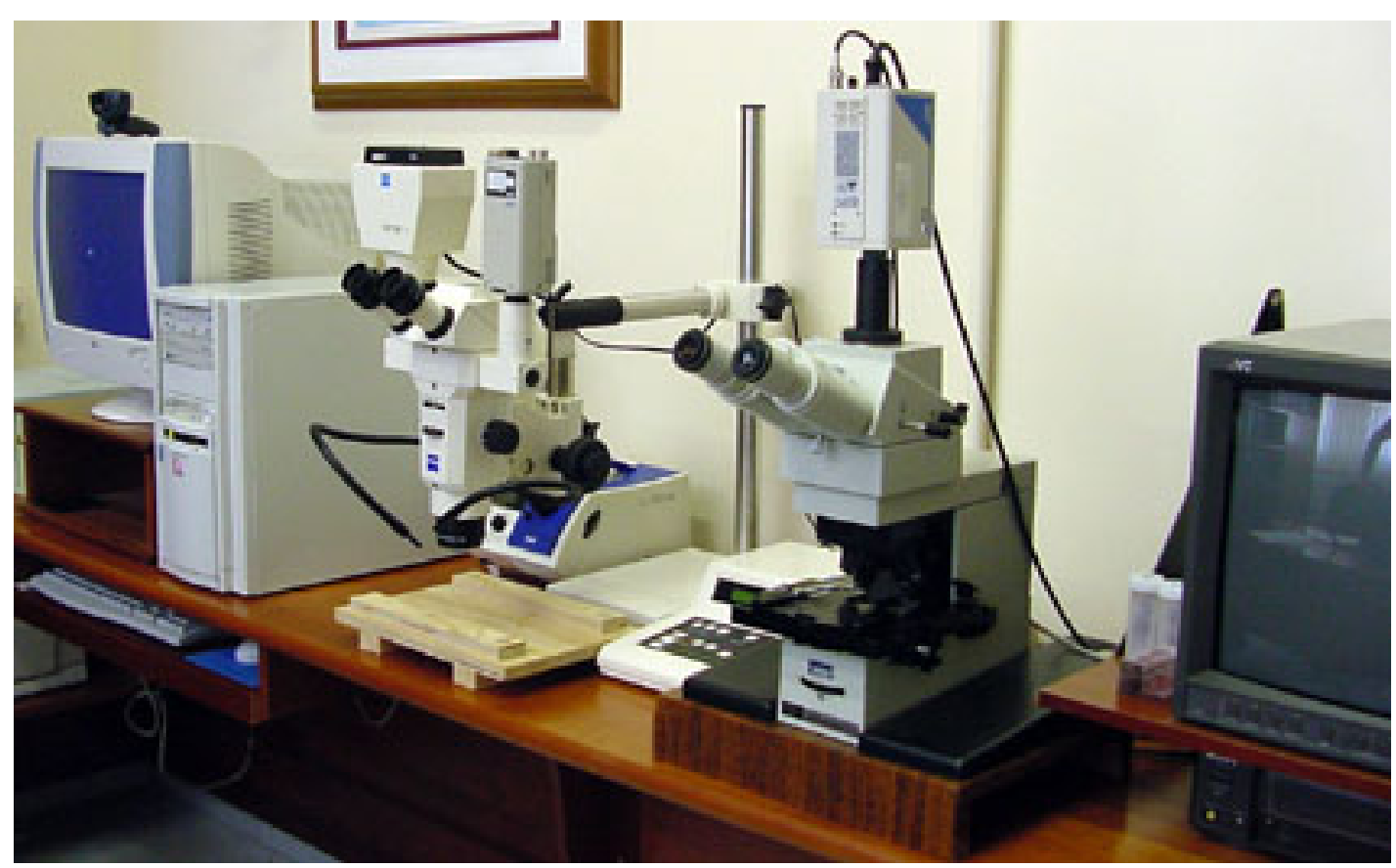

Figura 4 - Equipamentos utilizados para o registro, captura de imagens e análise dos espécimes

Os dados obtidos com a análise morfológica macroscópica e estereomicroscópica dos 20 espécimes foram registrados em uma tabela com as principais características comuns a todos os dentes: morfologia e início do sulco, sua extensão, localização e seu efeito sobre a junção amelocementária (tabela 3) 
Tabela 3 - Tabela para registro da distribuição dos aspectos característicos da presença do sulco palatogengival entre os dentes avaliados morfologicamente à microscopia eletrônica de varredura

\begin{tabular}{|c|c|c|c|c|c|c|c|c|c|c|c|c|}
\hline \multicolumn{2}{|c|}{ Espécimes } & 01 & 02 & 03 & 04 & 05 & 06 & 07 & 08 & 09 & 10 & Total \\
\hline \multirow{3}{*}{$\begin{array}{l}\text { Morfologia } \\
\text { do sulco }\end{array}$} & Depressão & & & & & & & & & & & \\
\hline & Ruga & & & & & & & & & & & \\
\hline & Fissura & & & & & & & & & & & \\
\hline \multirow{4}{*}{$\begin{array}{l}\text { Início do sulco } \\
\text { na coroa }\end{array}$} & Fossa & & & & & & & & & & & \\
\hline & Crista mesial & & & & & & & & & & & \\
\hline & Crista distal & & & & & & & & & & & \\
\hline & Central & & & & & & & & & & & \\
\hline \multirow{3}{*}{$\begin{array}{l}\text { Extensão além } \\
\text { da junção } \\
\text { amelocementária }\end{array}$} & $1 / 3$ cervical & & & & & & & & & & & \\
\hline & 1/3 médio & & & & & & & & & & & \\
\hline & 1/3 apical & & & & & & & & & & & \\
\hline \multirow{4}{*}{$\begin{array}{l}\text { Localização } \\
\text { na raiz }\end{array}$} & Vestibular & & & & & & & & & & & \\
\hline & Palatina & & & & & & & & & & & \\
\hline & Mesial & & & & & & & & & & & \\
\hline & Distal & & & & & & & & & & & \\
\hline \multirow{2}{*}{$\begin{array}{l}\text { Trajeto da junção } \\
\text { amelocementária }\end{array}$} & Degrau & & & & & & & & & & & \\
\hline & Contínua & & & & & & & & & & & \\
\hline
\end{tabular}

\subsubsection{Exame radiográfico}

Todos os dentes foram radiografados após o exame estereomicroscópico utilizando-se películas periapicais Kodak (EP21) expostos em um aparelho de raios X GE - 100, regulado para 70 quilovolts, 10 miliampères com 0,2 segundos de exposição e distância foco/filme de $30 \mathrm{~cm}$. 
Os dentes foram posicionados e expostos aos raios $X$ em um trajeto vestibulolingual.

Novas radiografias foram feitas durante a fase de preparo biomecânico com finalidade de certificar os passos operatórios de odontometria e limite apical. Devido ao complexo dente, bloco de resina e mufla que serão apresentados mais adiante no texto, houve a necessidade de aumentar o tempo de exposição dos espécimes para um segundo, a distância foco/filme permaneceu de $30 \mathrm{~cm}$ e a exposição aos raios $x$ também foi feita no trajeto vestibulolingual.

O processamento foi realizado manualmente, utilizando o método temperatura-tempo, com tempo de revelação de 2,5 minutos em solução Kodak GBX revelador e reforçador. A lavagem intermediária em água corrente foi de 20 segundos e o tempo de fixação foi de 10 minutos em solução Kodak GBX fixador e reforçador. A lavagem final em água corrente foi de 20 minutos e foram colocados em secadora por 60 minutos. Os filmes foram então montados em cartelas individuais para radiografias periapicais e identificados. Todos os procedimentos iniciais, intermediários e finais foram seguidos rigorosamente para cada radiografia, com a finalidade de padronização.

\subsubsection{Análise à microscopia eletrônica de varredura}

Os espécimes dentários foram limpos com escova dental, água e detergente, em seguida a região do sulco foi limpa com esponja de PVC embebida em hipoclorito de sódio (2,5\%). Após a limpeza, os espécimes foram desidratados em solução crescente de álcool, montados em bases de alumínio para a análise à microscopia eletrônica de varredura. A metalização foi feita em aparelho BAL-TECH SCD 050, com camada de ouro de 40-90nm aproximadamente. As amostras foram examinadas em microscópio eletrônico de varredura JEOL JSM-T 220A operando com 15 Kv, fotografando-se com câmara especial MAMUYA 50A MRH, acoplada ao aparelho, utilizando-se filme NEOPAN SS 120 (Fuji) em aumentos de 15 à 1000X. 




Figura 5 - Microscópio eletrônico de varredura utilizado no trabalho

Na análise do sulco palatogengival à microscopia eletrônica de varredura foram destacadas as características da superfície nas paredes constituintes do sulco palatogengival, em especial quanto à presença de áreas de reabsorção dentária, caracterizando-as quanto sua localização em apical, médio e cervical. Detectamos ainda a exposição e abertura de canalículos dentinários e a presença de cálculos na profundidade do sulco. Outros eventos e acidentes não programados, mas passíveis de observação também foram registrados.

Observaram-se ainda, as características da junção amelocementária, de forma comparativa, entre os vários espécimes.

A superfície do esmalte relacionada ao sulco palatogengival, de cada dente avaliado, foi examinada e compararam-se suas características com áreas não relacionadas ou próximas ao sulco. As invaginações do esmalte também foram investigadas nos espécimes avaliados.

Os dados obtidos nesta análise foram tabulados registrando a presença de possíveis alterações como: presença de cálculo dentário; comunicações entre a polpa e o periodonto; presença de reabsorções e as características morfológicas da junção amelocementária na região do sulco palatogengival, (tabela 4). 
Tabela 4 - Modelo da tabela para registro dos dados quanto às alterações relacionadas ao sulco palatogengival na análise à microscopia eletrônica de varredura

\begin{tabular}{|c|c|c|c|c|c|c|c|c|c|c|c|}
\hline \multicolumn{3}{|c|}{ Espécimes } & 01 & 02 & 03 & 04 & 05 & 06 & 07 & 08 & Total \\
\hline \multirow{4}{*}{ Cálculo } & \multirow{3}{*}{ presente } & coroa & & & & & & & & & \\
\hline & & junção & & & & & & & & & \\
\hline & & raiz & & & & & & & & & \\
\hline & \multicolumn{2}{|l|}{ ausente } & & & & & & & & & \\
\hline \multirow{3}{*}{$\begin{array}{c}\text { Comunicações } \\
\text { Polpa } \\
\text { Periodonto }\end{array}$} & \multicolumn{2}{|l|}{ forames } & & & & & & & & & \\
\hline & \multicolumn{2}{|l|}{ foraminas } & & & & & & & & & \\
\hline & \multicolumn{2}{|c|}{ túbulos expostos } & & & & & & & & & \\
\hline \multirow{3}{*}{$\begin{array}{l}\text { Tipo de junção } \\
\text { amelocementária }\end{array}$} & \multicolumn{2}{|l|}{ topo a topo } & & & & & & & & & \\
\hline & \multicolumn{2}{|l|}{ "gap" } & & & & & & & & & \\
\hline & \multicolumn{2}{|c|}{ cemento sobre esmalte } & & & & & & & & & \\
\hline \multirow{3}{*}{ Reabsorção } & \multicolumn{2}{|l|}{$1 / 3$ cervical } & & & & & & & & & \\
\hline & \multicolumn{2}{|l|}{ 1/3 médio } & & & & & & & & & \\
\hline & \multicolumn{2}{|l|}{ 1/3 apical } & & & & & & & & & \\
\hline
\end{tabular}

\subsubsection{Preparação dos espécimes para avaliação dos efeitos do preparo biomecânico}

A metodologia proposta por BORGES ${ }^{21}$ (1985) para a avaliação da instrumentação de canais radiculares serviu como base para a execução desta etapa. Foram introduzidas algumas modificações, a fim de tornar mais fácil a reprodução do método e de padronizar ao máximo o trabalho. 
Confeccionou-se um padrão para que todos os blocos de resina onde os dentes fossem incluídos ficassem semelhantes. Inicialmente o padrão foi esculpido em cera utilidade, com formato de prisma de base hexagonal, sulcos transversais foram esculpidos em cinco faces do prisma e sulcos longitudinais confeccionados na sexta face. Os sulcos atuam como guias que estabilizam o bloco nos sentidos: axial e transversal. O bloco então foi moldado com silicona de adição, obtendo-se um molde padrão para inclusão dos dentes.

Os dentes tiveram seus ápices protegidos por uma fina camada de cera utilidade. Em seguida, os dentes foram posicionados com a face palatina na direção da face com guias longitudinais do molde em todas as inclusões. Para estabilizar o dente na resina durante a polimerização utilizou-se um clipes de papel fixado no molde de silicona. O conjunto dente, resina acrílica incolor ativada quimicamente e molde de silicona foi então colocado numa panela de pressão com água fria com pressão de 3atm para polimerizar, minimizando a formação de bolhas internas decorrentes da evaporação do catalisador.

Após a presa da resina, fez-se o polimento do bloco numa politriz com lixa de granulação 800, aumentando a lisura superficial do bloco até que este apresente um aspecto vítreo. A forma de prisma de base hexagonal e o polimento do bloco têm o objetivo de facilitar a remoção do mesmo de dentro da mufla de gesso.

O bloco de resina, devidamente lubrificado, é posicionado em um dique de cera rosa $\mathrm{n}^{\circ} 7 \mathrm{com} 4 \mathrm{~cm}$ de altura e $8 \mathrm{~cm}$ de comprimento e $5 \mathrm{~cm}$ de largura, preenchido com gesso pedra especial recém preparado até que metade do bloco fique submersa. Após a presa do gesso desta face da mufla, são esculpidos no gesso dois sulcos de encaixe localizados lateralmente ao bloco de resina e então a superfície do gesso é lubrificada. Novamente é vazado o gesso recobrindo o bloco e preenchendo o restante do dique de cera. Três faces do bloco de resina ficam incluídas em cada metade da mufla. Desta maneira, cada dente foi incluído em um bloco de resina acrílica incolor, contido por uma mufla desmontável de gesso pedra. 
Desmontadas as muflas, os blocos de resina acrílica foram fixados com cera pegajosa na base de alumínio de um micrótomo de tecido duro* a fim de se obter cortes transversais em locais pré-estabelecidos como no terço cervical, médio e apical do dente. Com o intuito de perder o mínimo de estrutura dentária com os cortes, optou-se pelo uso de discos diamantados** de $0,3 \mathrm{~mm}$ de espessura. Como cada corte representou a perda de $0,3 \mathrm{~mm}$ de estrutura dentária optou-se pela realização de apenas dois cortes que geraram três fragmentos radiculares: um cervical, um médio e outro apical. Assim todo dente avaliado possuía $0,6 \mathrm{~mm}$ a menos de seu comprimento original previamente a sua instrumentação. Esse comprimento perdido foi mantido pela estabilização dos blocos pela mufla de gesso. Os métodos utilizados nesta parte do trabalho estão representados na figura 6 . Depois de observados à microscopia eletrônica de varredura os cortes foram novamente montados dentro da mufla de gesso, passando-se então ao preparo biomecânico. 


\section{FIGURA 6}

Figura 6A - Molde em silicona do padrão de cera onde os dentes foram incluídos na resina acrílica. Todas as inclusões em resina foram feitas neste molde que oferecia lisura superficial e as guias transversais e longitudinais aos blocos de resina. Assim todos os blocos obtidos apresentavam as mesmas características

Figura 6B - Esquema da inclusão do dente em bloco de resina com guias, realizado a partir de BORGES ${ }^{21}$ (1985). Neste trabalho desenvolveram-se blocos com formato de prisma de base hexagonal

Figura 6C- Esquema da construção da mufla de gesso realizado a partir de BORGES ${ }^{21}$ (1985). Três faces do bloco de resina ficaram incluídas em cada metade da mufla, a forma de prisma de base hexagonal e o polimento do bloco têm o objetivo de facilitar a remoção do mesmo de dentro da mufla de gesso

Figura 6D- Mufla de gesso pedra especial para o posicionamento do bloco de resina responsável por estabilizar os cortes durante o preparo biomecânico dos espécimes. Com a padronização, todas as muflas obtidas eram semelhantes 

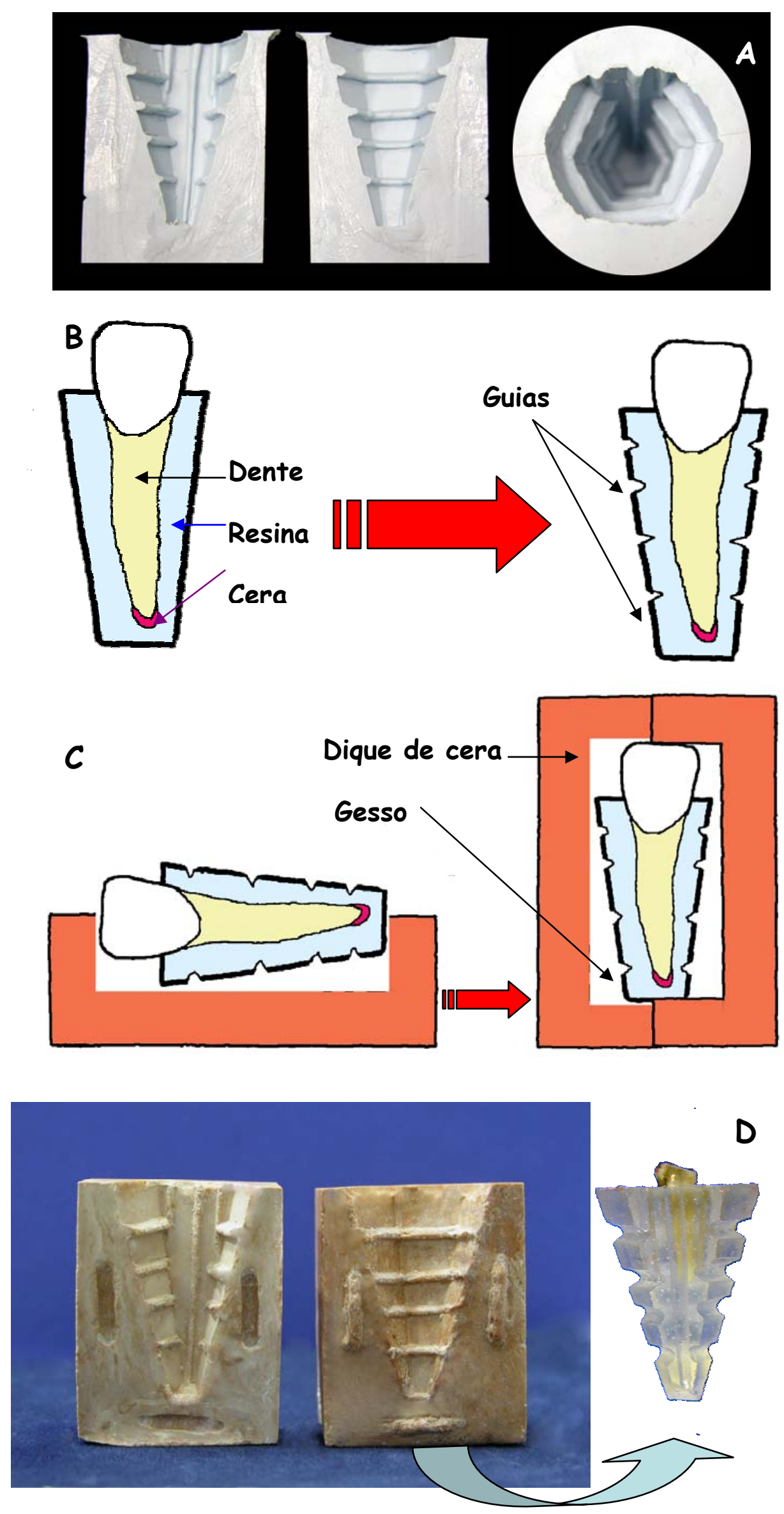


\subsubsection{Avaliação da morfologia do canal radicular antes do preparo biomecânico}

Estabeleceu-se um grupo controle a partir da seleção de espécimes que fossem representativos para o projeto, ou ainda, que pudessem de alguma forma contribuir na concepção de formas confiáveis de análise. Optou-se por avaliar a metodologia de BORGES ${ }^{21}$ (1985), em 12 espécimes constituídos por 2 incisivos centrais superiores normais, 3 incisivos laterais superiores normais e um com dilaceração radicular, 4 caninos normais superiores e 2 molares superiores portadores de raízes fusionadas em "C", comumente denominadas como "C-shape". A escolha dos espécimes é fruto da tentativa de comparação com os dentes portadores do sulco palatogengival, servindo como grupo controle para o trabalho. Os incisivos centrais e laterais normais servem de parâmetro de forma anatômica. O incisivo lateral com dilaceração radicular foi incluído devido a presença dessa alteração entre os espécimes da amostra experimental. Os caninos foram incluídos no piloto por possuírem um compartimento pulpar amplo, prestando-se para formulação de métodos para avaliar este componente no estudo. Finalmente os molares "C-shape", por apresentarem um grande sulco central entre as raízes fusionadas que causa danos semelhantes ao sulco palatogengival, fator de preocupação endodôntica e periodontal.

Com a obtenção das muflas, os blocos foram cortados, seguindo a metodologia proposta, e então preparados para a microscopia eletrônica de varredura. Os fragmentos dos blocos de resina foram limpos vigorosamente com esponjas de PVC banhadas em hipoclorito de sódio 2,5\%, depois em solução de EDTA 15\%, e finalmente em água destilada, para remoção da lama dentinária produzida pelo processo de corte. Cada secção de dente foi posicionada na base metálica, compatível com o microscópio, com esmalte de unha incolor. Como não se sabia o melhor posicionamento para a análise, no grupo controle as secções foram dispostas de duas maneiras: com a face lateral do bloco junto à base e com uma das partes seccionadas aderidas à base. 
A seguir, é demonstrado como as secções foram realizadas, seu posicionamento nas bases metálicas, as bases metálicas utilizadas, bem como o acondicionamento dos espécimes em recipientes livres de umidade, previamente ao exame à microscopia eletrônica de varredura.
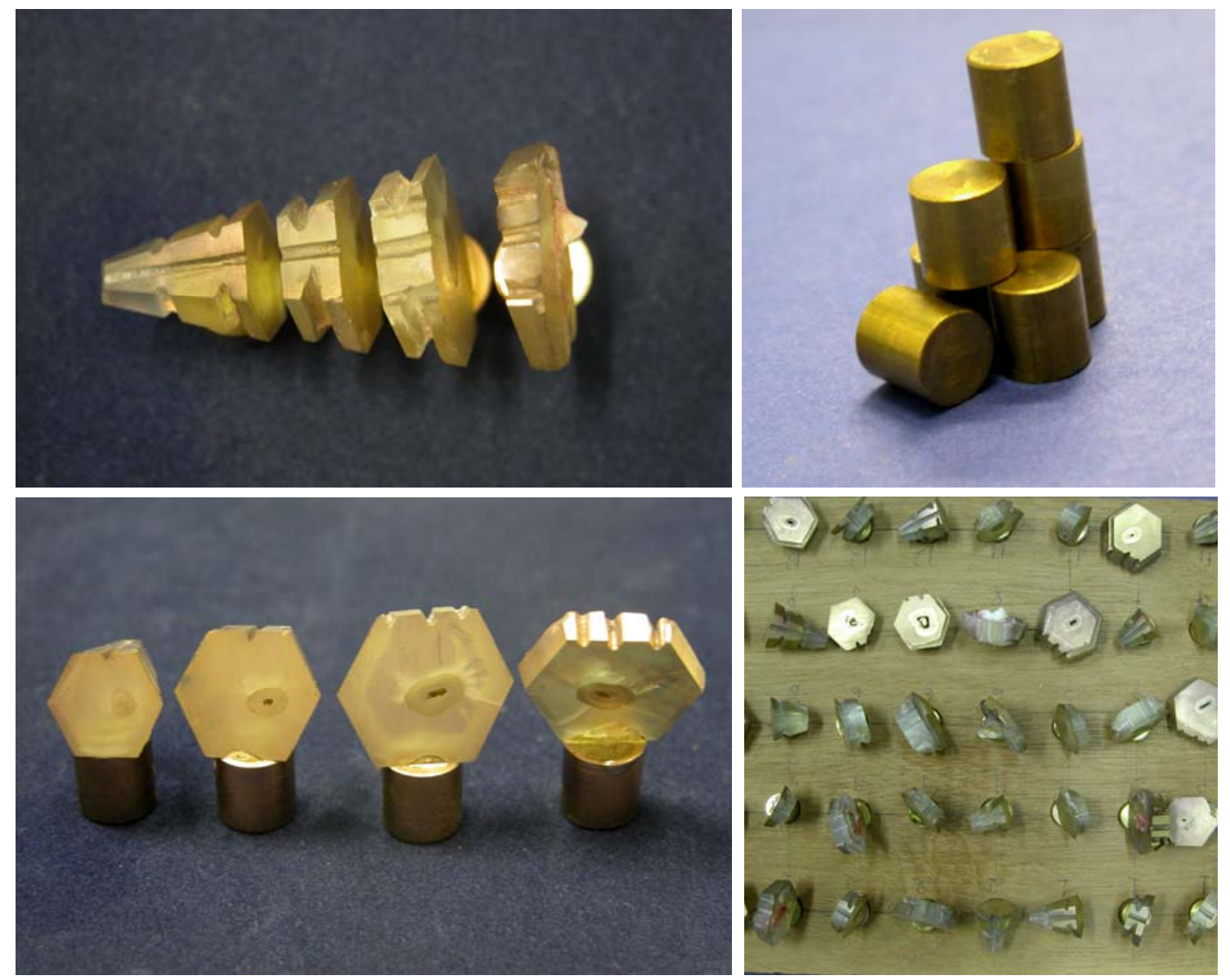

Figura 7 - Processo preparatório para a microscopia eletrônica de varredura. Nota-se o posicionamento do espécime na base metálica com esmalte incolor e o acondicionamento da amostra piloto

Após a realização do grupo controle ficou estabelecido que o melhor posicionamento para a análise das secções seria com uma das partes seccionadas aderida à base. Os cortes foram preparados e observados à microscopia eletrônica de varredura antes do preparo biomecânico para futuras comparações. A análise da morfologia dos canais antes do preparo biomecânico levaria em consideração os seguintes aspectos: 
a) Alterações morfológicas do sistema de canais radiculares pela presença do sulco palatogengival nos terços cervical, médio e apical;

b) Relação do canal radicular com as faces mesiodistal e vestíbulolingual.

c) Relação dentina-cemento próximas à região do sulco palatogengival.

\subsubsection{Preparo biomecânico}

Os dentes foram preparados utilizando a técnica de instrumentação com dilatação dos dois terços coronários do canal radicular com auxilio de fresas especiais complementada com escalonamento, conforme LEONARDO; LEAL ${ }^{84}$ (1998):

a) Abertura, radiografia de odontometria;

b) Preparo do batente apical 3 limas mais calibrosas que a lima do diâmetro anatômico, $1 \mathrm{~mm}$ aquém do ápice radiográfico, estabelecendo o "instrumento memória";

c) Instrumentação coroa-ápice com utilização de fresas GatesGlidden 2-5, dependendo do calibre do canal, mantendo cerca de $5 \mathrm{~mm}$ de remanescente radicular para o preparo manual;

d) Recuo progressivo anatômico a partir do batente apical.

A irrigação dos canais foi feita com solução de hipoclorito de sódio a 2,5\%, e a instrumentação realizada com limas "Maillefer Fexofile" ou até mesmo "Nitiflex" dependendo das condições anatômicas do caso. 


\subsubsection{Análise à microscopia eletrônica de varredura}

Depois da fase do preparo biomecânico, os fragmentos dos blocos de resina foram novamente limpos vigorosamente com esponjas de PVC banhadas em hipoclorito de sódio 2,5\%, depois em solução de EDTA 15\%, e finalmente em água destilada, para remoção da lama dentinária produzida pela instrumentação. Para certificar-se que todo resíduo tinha sido removido, a limpeza só terminaria após a camada de metalização áurea tivesse sido removida. Os fragmentos foram novamente fixados nas bases metálicas com esmalte de unha incolor e mantidos em ambiente desumudificado por ar refrigerado durante $24 \mathrm{~h}$, para nova metalização.

Após metalizados, os fragmentos estavam preparados para serem novamente observados à microscopia eletrônica de varredura onde os seguintes aspectos foram comparados as alterações morfológicas do sistema de canais radiculares pelo preparo biomecânico:

$>$ Contorno, forma e limites do preparo;

> Possíveis deformações anatômicas como desgaste excessivo de uma das paredes, desvios ou perfurações nos terços cervical, médio e apical.

Com a finalidade de gerar dados quantitativos comparativos para esta análise, as fotografias obtidas nas observações antes e depois do preparo biomecânico foram digitalizadas e analisadas com o software Image J 1.32j*. O aumento escolhido para tais comparações foi de $15 \mathrm{x}$ com as medidas calibradas em milímetros. Foram tomadas as seguintes mensurações das imagens obtidas antes e depois do preparo biomecânico:

a) Distância entre a parede do canal radicular à interface cemento resina do fundo do leito do sulco palatogengival em cada secção;

b) Distância de outros três pontos das paredes do interior do canal à interface cemento resina de outras faces da secção da raiz, 
buscando a maior eqüidistância possível entre as medidas em cada secção como na representação esquemática a seguir:

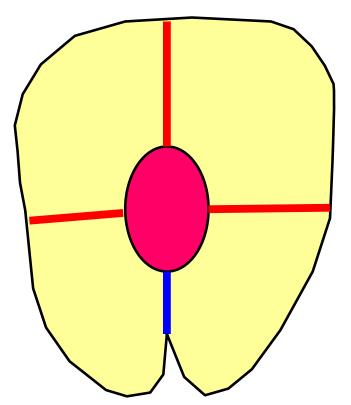

Figura 8 - Representação esquemática das medidas de espessura das paredes dentinárias do canal. Em azul a medida relacionada ao sulco palatogengival e em vermelho as medidas auxiliares

c) Medida da área do canal em cada secção.

\subsection{Análise estatística}

Os dados encontrados nas fichas dos pacientes quanto ao tipo facial, a relação entre os arcos, o histórico familiar e a presença de anodontia parcial foram tabulados em planilha do software Pacotico (Pacotinho Estatístico V: 4.4) e submetidos, ao teste estatístico do qui-quadrado, testando a hipótese de que havia ou não diferença estatística entre os vários grupos considerados e a presença do sulco palatogengival.

Para a análise dos dados obtidos com a mensuração das alterações produzidas pelo preparo biomecânico, foi aplicado o teste ANOVA para análise de variância entre as diferenças das distâncias medidas antes e depois do preparo nos grupos de secções cervical, média e apical. O teste de Tukey foi aplicado em seguida para comparações individuais. A análise de concordância entre as medidas das secções foi realizada através do índice kappa intraexaminador ${ }^{78}$ seguindo os seguintes critérios: <0,0 nulo, 0,0-0,2 baixo, de 0,21-0,4 médio, de 0,41-0,6 moderado, de 0,61-0,8 substancial e de 0,81-1 quase perfeito.

O nível de significância considerado em todas as análises foi de $5 \%$. 


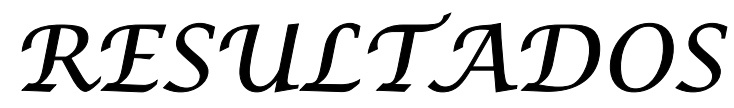




\section{RESULTADOS}

\section{1 Análise dos resultados da parte $A$}

\section{1. 1 Freqüência do sulco palatogengival}

Foram examinados 500 pacientes com idades entre 6 e 68 anos (figura 9), 178 homens e 322 mulheres. Dentre estes, 99 pacientes são portadores do sulco palatogengival, representando uma prevalência de 19,8\% da amostra. Dos pacientes com sulco palatogengival, 58 eram do gênero feminino, equivalente a $18,01 \%$ de todas as mulheres examinadas, e 41 pacientes do gênero masculino, 23,03\% dos homens da amostra, não havendo diferença de prevalência estatisticamente significante ( $p>0.05)$ entre os gêneros (tabela 5$)$.



Faixa etária

Figura 9 - Distribuição dos 500 pacientes examinados em relação à faixa etária e o gênero 
Tabela 5 - Distribuição dos pacientes avaliados quanto à presença do sulco palatogengival e o gênero em relação aos indivíduos portadores do sulco palatogengival e ao total da amostra

\begin{tabular}{ccccccc}
\hline \multirow{2}{*}{ Gênero } & Com sulco & Sem sulco & total & \multicolumn{2}{c}{ Prevalência } \\
\cline { 5 - 6 } & & & & & com sulco & toda a amostra \\
\hline homens & 41 & 137 & 178 & $35,6 \%$ & $23,03 \%$ \\
mulheres & 58 & 264 & 322 & $64,4 \%$ & $18,01 \%$ \\
total & 99 & 401 & 500 & $100 \%$ & $19,8 \%$ \\
\hline
\end{tabular}

A distribuição dos pacientes entre quanto à cor da pele leucoderma, melanoderma e xantoderma foi observado a maior prevalência de leucodermos com 405 pacientes (81\% da amostra), seguido por melanodermos 86 (17,2\% da amostra) e apenas 9 pacientes xantodermos (1,8\% da amostra). A presença do sulco palatogengival foi observada em: 78 pacientes leucodermos, equivalente a $19,27 \%$ do total de leucodermos; 20 pacientes melanodermos, equivalente a $23,24 \%$ de todos os indivíduos melanodermos; um paciente xantodermo, equivalente a $11,11 \%$ dos indivíduos xantodermos. Não houve diferença de prevalência estatisticamente significante $(p>0.05)$ entre as cores de pele quanto à presença do sulco palatogengival.

Tabela 6 - Distribuição dos 500 pacientes examinados quanto à presença do sulco palatogengival em relação à cor da pele

\begin{tabular}{ccccc}
\hline Cor da pele & Com sulco & Sem sulco & total & Porcentagem \\
\hline leucoderma & 78 & 327 & 405 & $81 \%$ \\
melanoderma & 20 & 66 & 86 & $17,2 \%$ \\
xantoderma & 1 & 8 & 9 & $1,8 \%$ \\
total & 99 & 401 & 500 & $100 \%$ \\
\hline
\end{tabular}




\section{1. 2 Dos resultados clínicos e radiográficos}

A avaliação clínica e radiográfica dos pacientes portadores do sulco palatogengival demonstrou que 29 pacientes $(29,29 \%$ dos pacientes portadores do sulco palatogengival) apresentaram profundidade de bolsa na região do sulco maior que $2 \mathrm{~mm}$ em 38 dentes (tabela 7). Porém, em apenas cinco pacientes essa profundidade foi maior que $3 \mathrm{~mm}$, sendo três casos com profundidade de sondagem de $4 \mathrm{~mm}$ e dois casos com bolsa periodontal de $5 \mathrm{~mm}$ de profundidade totalizando 6 dentes comprometidos. Esses cinco pacientes necessitaram de tratamento periodontal com raspagem e alisamento radicular, foram realizados procedimentos cirúrgicos com remoção do sulco por odontoplastia e gengivoplastia em três destes e nos outros dois, após a odontoplastia a região do sulco foi isolada e a cavidade restaurada com resina composta.

Três pacientes apresentaram sulco palatogengival e tratamento endodôntico prévio no dente afetado, foram três incisivos laterais superiores, nestes casos nenhuma alteração periodontal estava presente. Como os três casos apresentavam-se sem sintomatologia ou sinais clínicos e radiográficos de insucesso endodôntico, não houve necessidade de intervenção endodôntica suplementar. Em um dos casos, porém, foi indicado o tratamento restaurador, pois a restauração antiga apresentava discreta infiltração por cárie.

Houve ainda 7 pacientes com 10 dentes apresentando lesões cariosas na região coronária do sulco palatogengival. A região do cíngulo foi a mais comprometida, procedeu-se a remoção do tecido cariado e a restauração da área comprometida.

No total foram 39 pacientes, $7,8 \%$ da amostra apresentaram alguma alteração dentária decorrente do sulco palatogengival em 51 incisivos superiores (tabela 8) onde efetivamente 19 dentes necessitaram de intervenção clínica. 
Tabela 7 - Distribuição dos casos de sulco palatogengival em relação à profundidade de sondagem obtidos na amostra

\begin{tabular}{ccccc}
\hline \multirow{2}{*}{ Dentes } & \multicolumn{2}{c}{ Profundidade de sondagem em mm } & \multirow{2}{*}{ total } \\
\cline { 2 - 4 } & 3 & 4 & 5 & \\
\hline 11 & 2 & 0 & 1 & 3 \\
21 & 1 & 0 & 0 & 1 \\
11 e 21 & 2 & 0 & 0 & 2 \\
12 & 7 & 1 & 1 & 9 \\
22 & 6 & 1 & 0 & 7 \\
12 e 22 & 6 & 1 & 0 & 7 \\
pacientes & 24 & 3 & 2 & 29 \\
dentes & 32 & 4 & 2 & 38 \\
\hline
\end{tabular}

Tabela 8 - Distribuição dos pacientes e dos dentes portadores do sulco palatogengival em relação à necessidade de tratamento

\begin{tabular}{cccc}
\hline Comprometimento & Pacientes & Dentes & Dentes tratados \\
\hline endodôntico & 3 & 3 & $3^{*}$ \\
periodontal & 28 & 37 & 5 \\
perio com cárie & 1 & 1 & 1 \\
somente cárie & 7 & 10 & 10 \\
total & 39 & 51 & 19
\end{tabular}

\footnotetext{
* Um incisivo lateral superior entre os dentes com tratamento endodôntico prévio necessitou de nova restauração estética devido à infiltração por cárie na região da abertura coronária.
} 
Os 60 pacientes acometidos pelo sulco palatogengival que não apresentavam qualquer comprometimento periodontal, endodôntico e/ou carioso, não sabiam que eram portadores do sulco palatogengival. Estes pacientes se beneficiaram com noções de cuidados especiais de higiene dos dentes comprometidos e prevenção das possíveis alterações associadas ao sulco palatogengival.
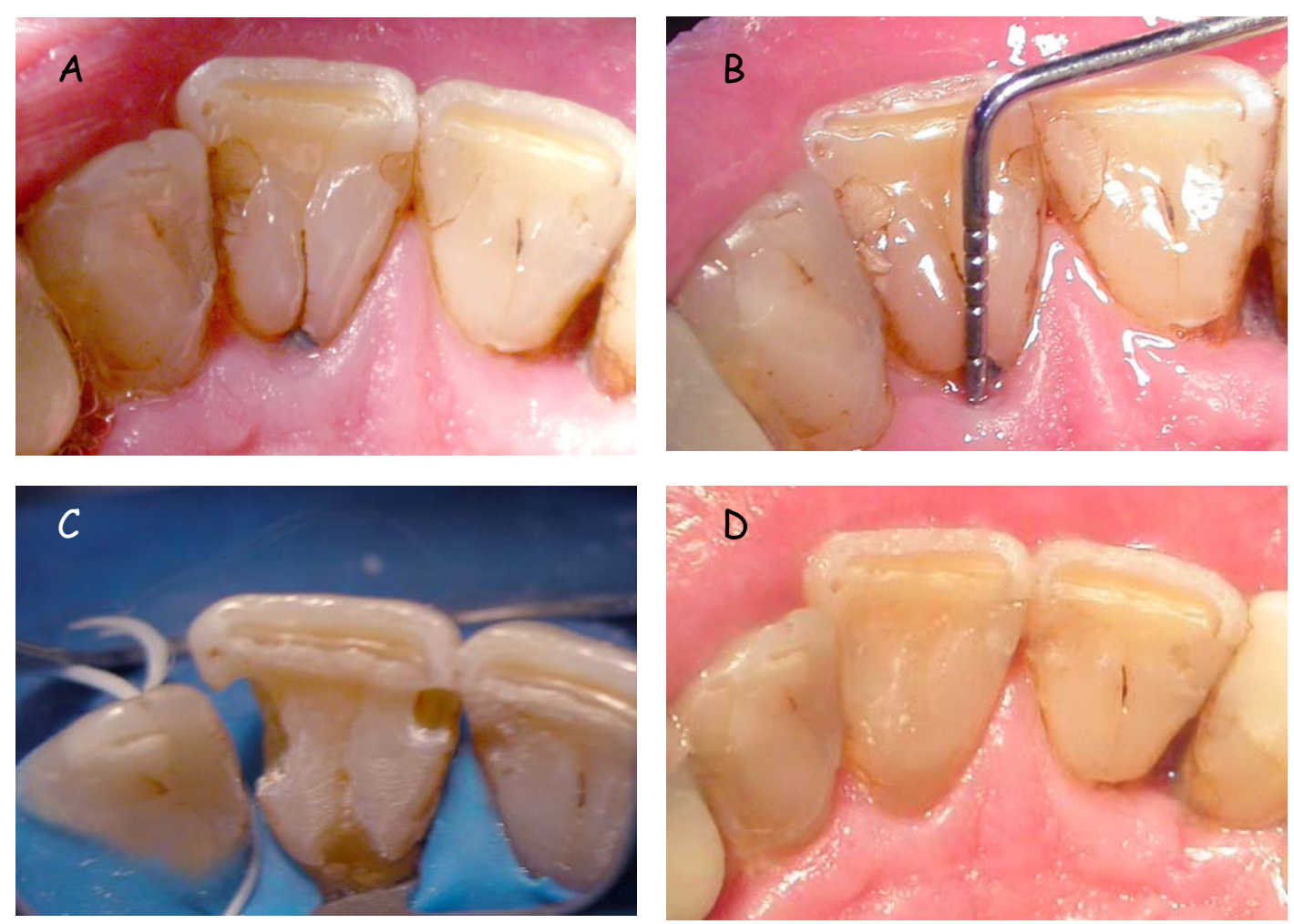

Figura 10 - Paciente portador do sulco que apresentava bolsa periodontal com secreção purulenta. Realizou-se tratamento periodontal e restaurador, com acompanhamento de cinco semanas da recuperação clínica

Foram detectados 148 incisivos superiores com sulco palatogengival, 119 incisivos laterais $(80,4 \%$ dos dentes afetados) e 29 incisivos centrais (19,6\% dos dentes afetados). A maior prevalência foi de incisivos laterais unilaterais com 51,52\% dos casos, seguido por incisivos laterais bilaterais com $29,29 \%$ das ocorrências, os incisivos superiores unilaterais ocorreram em 
9,09\% e bilateralmente em 5,05\% dos casos. Outra observação importante foi de 5 casos (prevalência de 5,05\%) onde foram detectados sulcos nos quatro incisivos superiores.

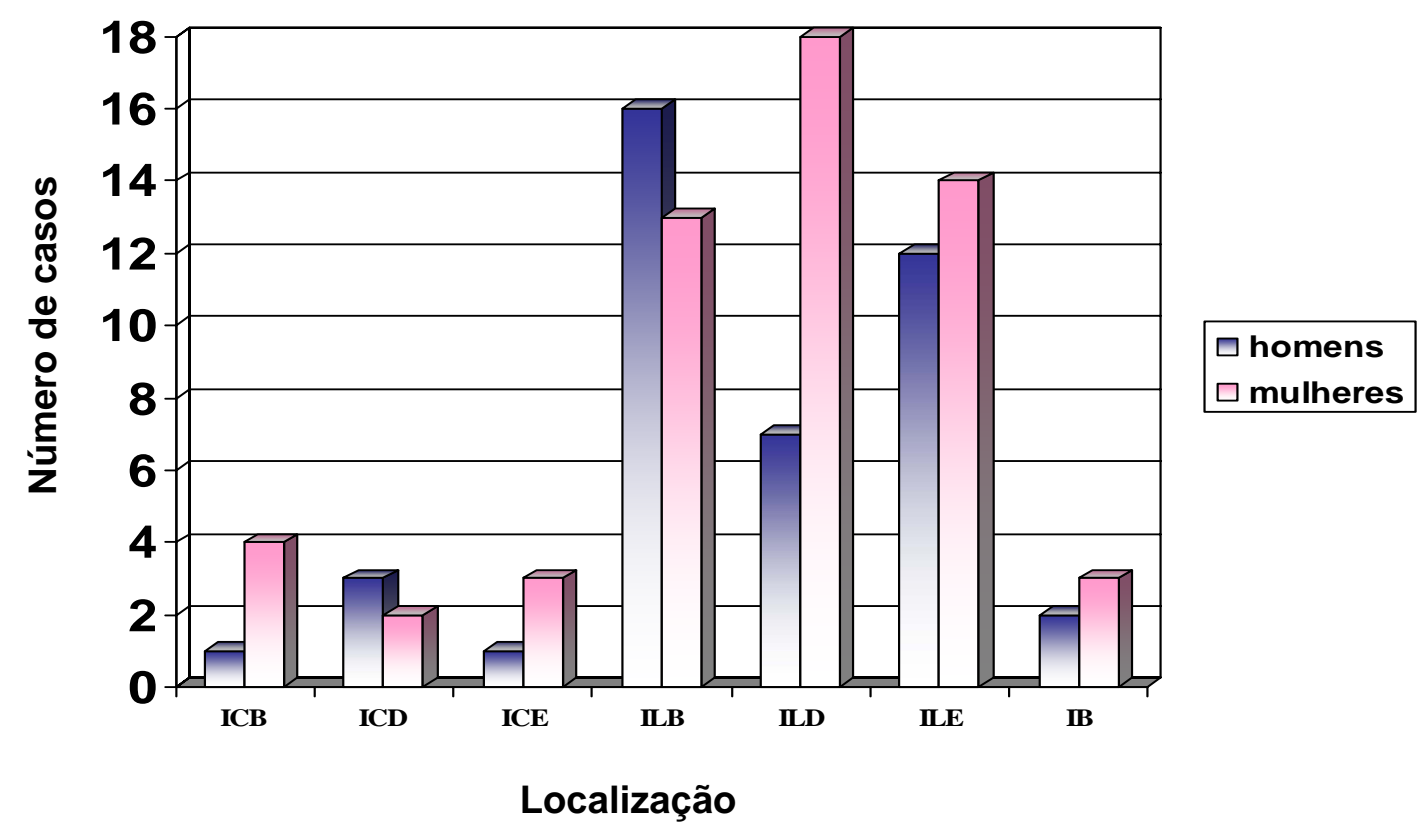

Figura 11 - Distribuição dos 148 casos de dentes portadores de sulco palatogengival existentes entre os 500 pacientes examinados ( $\mathrm{I}=$ incisivos superiores, $\mathrm{IC}=$ incisivo central superior, IL = incisivo lateral superior, B, D e E = bilateral, direito e esquerdo respectivamente)

\section{1. 3 Relação do tipo facial com o sulco palatogengival}

Em relação aos tipos faciais observou-se a maior prevalência do tipo mesocéfalo presente em 337 pacientes, 67,4\% da amostra. Esse também foi 0 tipo facial mais comum entre os portadores do sulco palatogengival ocorrendo em 71 pacientes, $71,72 \%$ dos pacientes com o sulco. O tipo facial dolicocéfalo 
e braquicéfalo tiveram prevalência semelhante na amostra, 83 pacientes $(16,6 \%)$ foram caracterizados como dolicocéfalos e 80 (16\%) como braquicéfalos. Os resultados destes tipos faciais também foram bem próximos entre os pacientes com sulco palatogengival, encontrou-se 15 pacientes dolicocéfalos, $15,15 \%$ dos portadores do sulco e 13 pacientes braquicéfalos, $13,13 \%$ de prevalência entre os portadores do sulco palatogengival. Não houve diferença significante estatisticamente entre os indivíduos com sulco palatogengival e sem a presença do sulco $(p>0,05)$ em relação ao tipo facial.

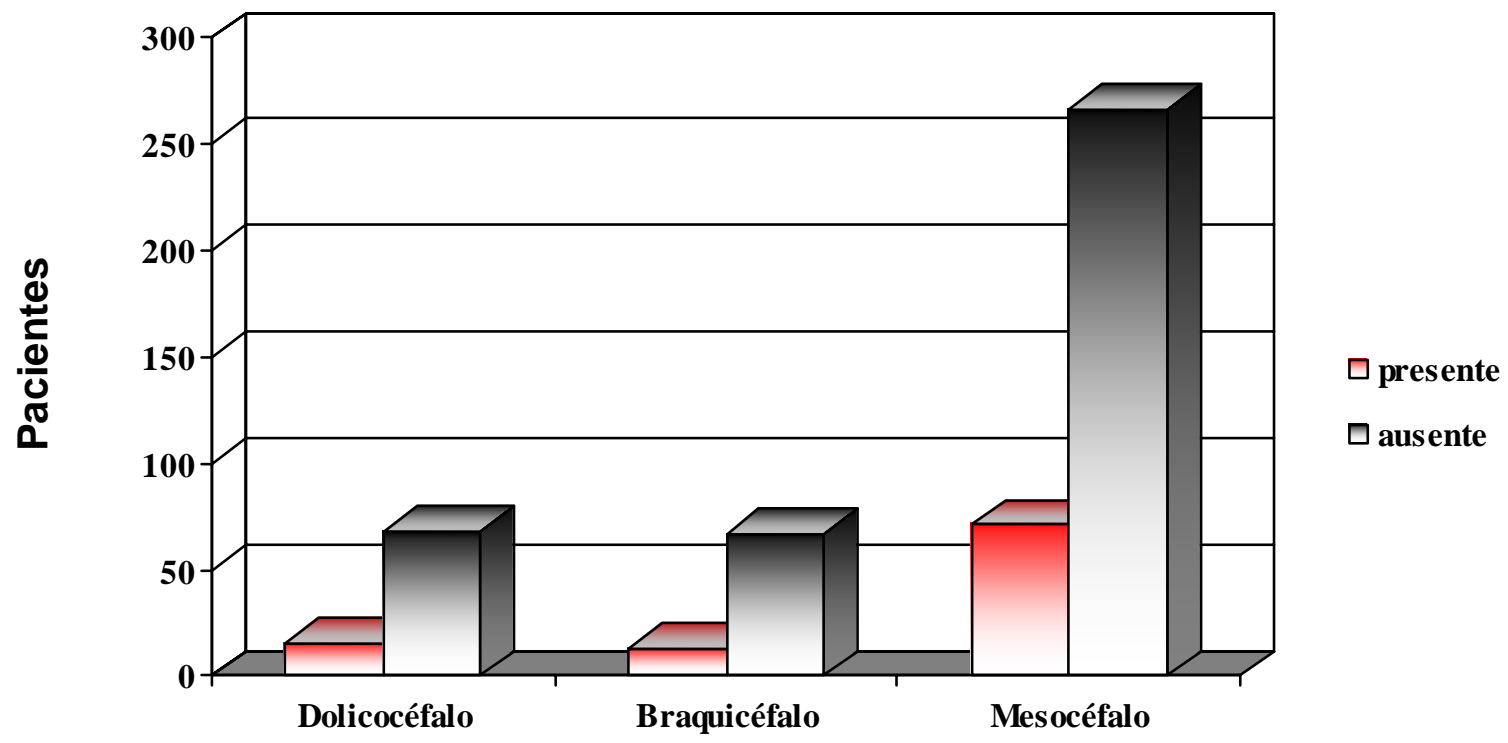

Tipo facial

Figura 12 - Distribuição comparativa da presença e ausência do sulco palatogengival e o tipo facial na amostra de 500 pacientes examinados, 99 destes portadores do sulco palatogengival

\section{1. 4 Relação da presença do sulco palatogengival com a relação entre os arcos dentários}

A relação entre os arcos dentários também não mostrou diferença significante estatisticamente. $\mathrm{Na}$ comparação entre os pacientes com e sem 0 sulco palatogengival, essa característica não foi significante com p>0,05. 
Quanto a relação entre os arcos observou-se 326 indivíduos classe 1, que formaram a maior prevalência na amostra, 65,2\% dos 500 pacientes avaliados. Essa característica também se apresentou na maioria dos indivíduos com sulco palatogengival com 56 pacientes (56,57\%) portadores do sulco classe 1 do total de indivíduos com o sulco. Em seguida os indivíduos classe 2 representaram 19,6\% de toda a população com 132 pessoas apresentando essa característica, 34 delas com sulco palatogengival (34,34\% dos portadores do sulco). A classe 3 foi a relação entre os arcos com menor prevalência, apenas 42 pacientes, 8,4\% dos indivíduos avaliados, têm essa característica e somente nove destes apresentam o sulco palatogengival $(9,09 \%$ dos portadores).



Relação entre os arcos

Figura 13 - Distribuição comparativa entre pacientes examinados quanto sua relação entre os arcos de acordo com a classificação de $\operatorname{ANGLE}^{6}$ e a presença do sulco palatogengival 


\section{1. 5 Relação entre a forma dos arcos e o sulco palatogengival}

A avaliação da característica forma dos arcos revelou uma maior prevalência do arco ovóide com 271 pacientes, 54,2\% dos pacientes avaliados. Em seguida o arco triangular teve prevalência de 28,4\% por estar presente em 142 pacientes, e a forma de arco de menor prevalência foi o arco quadrado com apenas 87 pacientes, $17,4 \%$ dos pacientes avaliados. Nenhuma diferença significante estatisticamente foi observada nesta característica física em relação à presença do sulco palatogengival, a comparação entre as pessoas com e sem o sulco apresentou uma contingência com $p>0,05$, da mesma maneira como ocorreu com o tipo facial e a relação entre os arco. Foi observado um padrão muito similar de prevalência entre os indivíduos com o sulco palatogengival, o arco ovóide foi observado em 54 pacientes (54,55\% dos pacientes com sulco palatogengival), o triangular em 30 (30,3\%) e o quadrado em $15(15,15 \%)$.

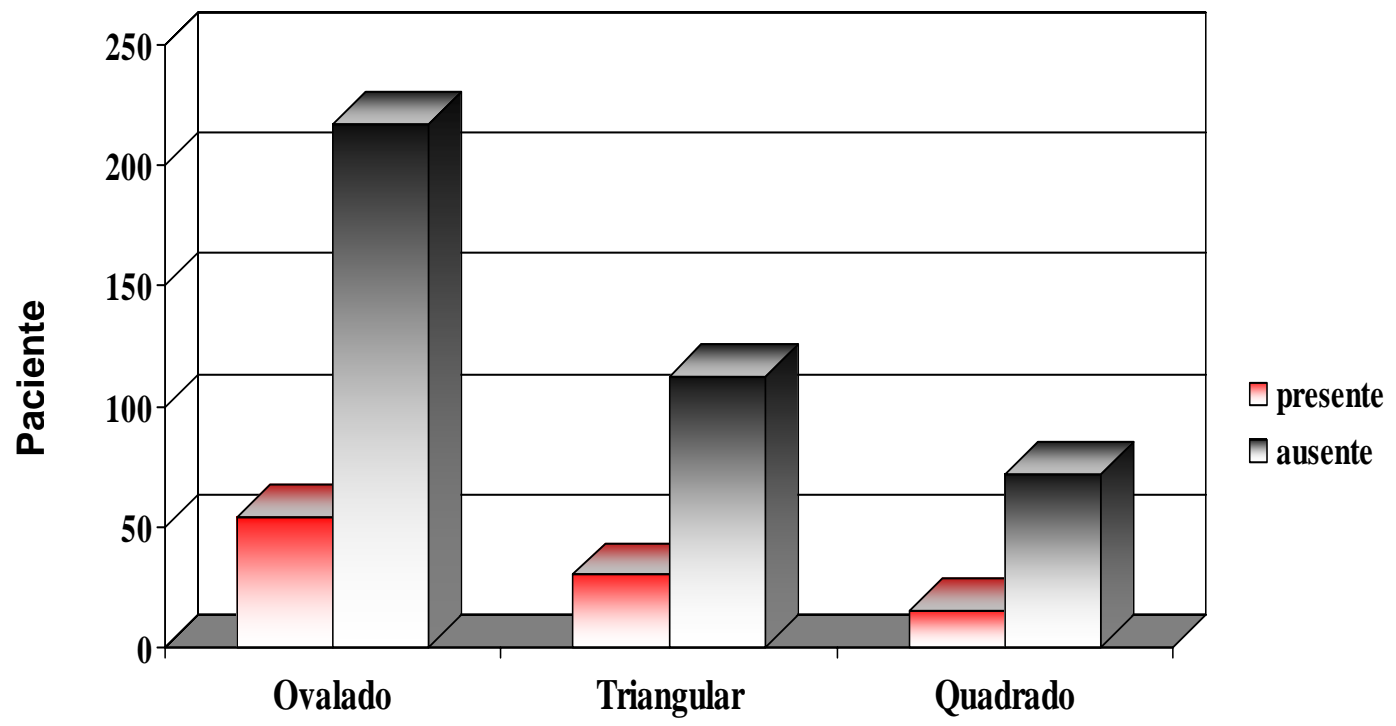

Forma dos arcos

Figura 14 - Distribuição dos pacientes examinados quanto à forma de seus arcos dentários e a presença do sulco palatogengival 


\section{1. 6 Relação do sulco palatogengival com outros fatores estudados}

Nenhum paciente examinado informou conhecer a existência do sulco palatogengival, nem tampouco sabiam se eram portadores, logo, nenhum deles pôde informar se existia histórico familiar desta alteração. Esta verificação foi constatada apenas com o exame de indivíduos da família de cinco portadores do sulco. A oportunidade surgiu porque alguns parentes de pacientes avaliados, também estavam sendo tratados nas clínicas da faculdade. Esses pacientes foram convidados a participar da pesquisa depois de constatado a presença do sulco no seu ente. Houve ainda alguns indivíduos que se ofereceram a participar da pesquisa, despertados pelo interesse de saber se também portavam a alteração. Foi possível avaliar 18 pessoas pertencentes a cinco famílias diferentes, porém não foram avaliados necessariamente todos os integrantes de cada grupo familiar.

Três famílias apresentaram mais de um componente com sulco palatogengival: uma delas tinha o pai e uma filha com sulco, e um outro irmão avaliado sem o defeito; em outra, o pai não tinha os incisivos superiores, a mãe não apresentava o sulco e dois dos três filhos do casal possuíam o defeito, na terceira família pai e mãe não possuíam os incisivos superiores passiveis de exame pela presença de próteses, porém todas as quatro filhas do casal apresentaram o sulco, sendo duas delas eram gêmeas. As outras quatro pessoas avaliadas eram pertencentes a duas famílias distintas compostas por: pai portador do sulco e seu filho sem o defeito; e na outra família, uma mãe sem o sulco com sua filha portadora da alteração.

Dos 500 pacientes examinados, apenas 12 apresentaram anodontia parcial, sendo que um destes é portador do sulco palatogengival. Constatou-se que nos pacientes examinados com anodontia parcial a morfologia de todos os dentes apresentava-se simplificada, com número de cúspides reduzido, ausência do tubérculo de Carabelli, além de sulcos oclusais pouco evidentes. A 
correlação da possível influência do fator genético inerente a anodontia parcial, com a diminuição da ocorrência do sulco palatogengival não pode ser atingida.

A documentação fotográfica e radiográfica dos pacientes que foram diagnosticados a presença do sulco palatogengival contribuiu para a compreensão de diferentes situações clínicas envolvidas com a presença do sulco. A seguir estão dispostos em tópicos os achados decorrentes da avaliação clínica dos pacientes acometidos pelo sulco palatogengival:

> A maioria dos pacientes portadores do sulco palatogengival não apresenta qualquer comprometimento no dente afetado. Nestes casos o diagnóstico precoce serve de alerta para o paciente de sua condição e dos riscos relacionados à presença do sulco;

As condições de higiene bucal do paciente, o período em que o dente ficou na boca exposto aos fatores ambientais e possíveis intervenções profissionais podem influenciar no estado clínico dos dentes portadores;

$>$ O sulco palatogengival ocorre também, em alguns casos distintos, devido à presença de outras formas de distúrbio do desenvolvimento dentário, como, por exemplo, a geminação dentária constatada em um dos pacientes examinados. Neste paciente, o distúrbio acarretou o aparecimento de sulcos profundos nas faces vestibular e lingual dos incisivos centrais afetados. Tal constatação é importante na prevenção das seqüelas do sulco palatogengival da face lingual e do sulco vestibular vertical da face vestibular, pois ambos, dependendo da higiene bucal do paciente e também da profundidade e extensão dos sulcos, servem de local propício para o acúmulo de placa microbiana, que pode dar início a um processo carioso ou provocar doença periodontal localizada. 
$>$ O correto diagnóstico do sulco pelos Cirurgiões Dentistas que intervêm nos pacientes que apresentam o sulco palatogengival nos incisivos superiores mostrou-se importante na conduta clínica perante as alterações relacionadas ao sulco; 


\section{FIGURA 15}

Figura 15A - Documentação de um paciente portador do sulco, porém sem qualquer alteração nos dois dentes afetados, devido à boa higiene bucal

Figura 15B - As radiografias revelam as tênues linhas radiolúcidas que partem da região dos cíngulos e se estendem apicalmente em direção à crista alveolar mesial, indicando a presença do sulco (setas amarelas)

Figura 15C - Características clínicas de outro paciente com sulco palatogengival no dente 12 apresentando boa aparência da mucosa gengival

Figura 15D - A sondagem periodontal revelou bolsa localizada com $4 \mathrm{~mm}$ de profundidade e sangramento à sondagem

Figura 15E - Radiograficamente observa-se o sulco palatogengival (seta amarela) e perda horizontal da crista óssea alveolar devido à doença periodontal generalizada (tracejado preto). Notam-se ainda o arredondamento apical dos incisivos superiores (setas azuis), causado por tratamento ortodôntico realizado

Figura 15F - Paciente portador dos sulcos vestibular vertical e palatogengival decorrentes de uma geminação dentária. Nota-se a aumento de volume gengival na face vestibular e o acúmulo de placa em todos os dentes, devido à higiene deficiente

Figura 15G - Destaca-se a presença de profundos sulcos palatogengivais bilaterais nos incisivos centrais. A mucosa da região da interface entre a gengiva e o sulco palatogengival encontra-se avermelhada e aumentada

Figura 15H - Na radiografia periapical observa-se o compartimento pulpar anômalo do dente. Estes achados radiográficos são bem distintos daqueles encontrados em casos de sulco palatogengival comuns

Figura 15I - Paciente com material restaurador devido à cárie na região do cíngulo, mas o sulco palatogengival não foi diagnosticado pelo profissional

Figura 15J - Maior aumento da região demonstrando o sulco palatogengival pigmentado e estendendo-se apicalmente

Figura 15K - Vista superior do mesmo dente demonstrando que a mucosa gengival acompanha a reentrância do sulco palatogengival

Figura 15L - Mesmo com ausência de sintomatologia e com profundidade de sondagem de bolsa de $2 \mathrm{~mm}$ é possível observar uma discreta alteração de coloração da mucosa gengival na região do sulco 







\subsection{Análise dos resultados da parte B:}

A amostra de dentes portadores do sulco palatogengival utilizada no presente estudo é composta por 15 incisivos laterais superiores e 5 incisivos centrais superiores. A seguir, os resultados encontram-se distribuídas por tópicos, discriminando o tipo de análise referente a esta parte do trabalho.

\subsubsection{Exame macroscópico e estereomicroscópico}

Os espécimes serão descritos morfologicamente, de forma separada e seqüencial de 1 a 20. A raiz e a coroa foram divididas em terços, após uma inspeção global do dente. Os dados observados na macroscopia foram confirmados ao estereomicroscópio. Abaixo estão dispostos os espécimes com seus respectivos números de identificação e em seguida sua descrição morfológica individualizada.

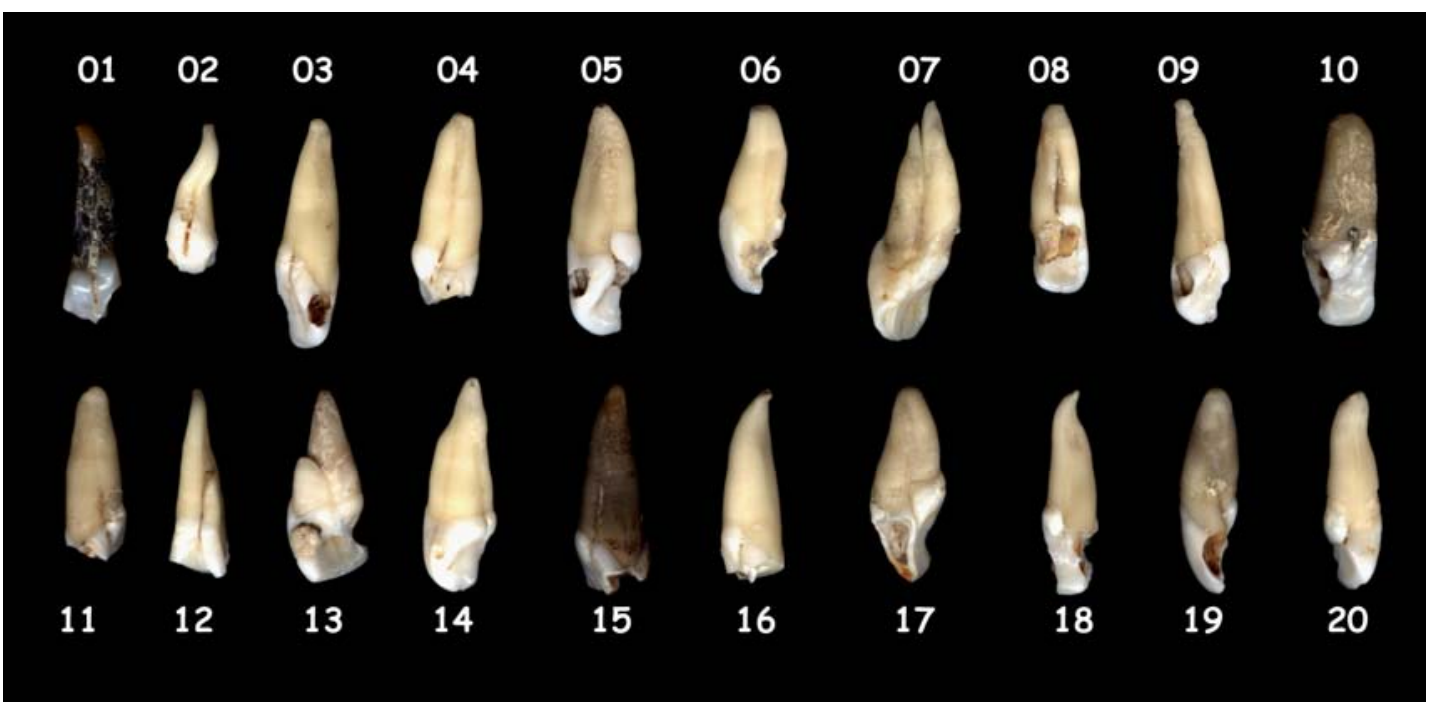

Figura 16 - Visão geral da amostra antes do preparo para análise da morfologia externa e interna à microscopia eletrônica de varredura 


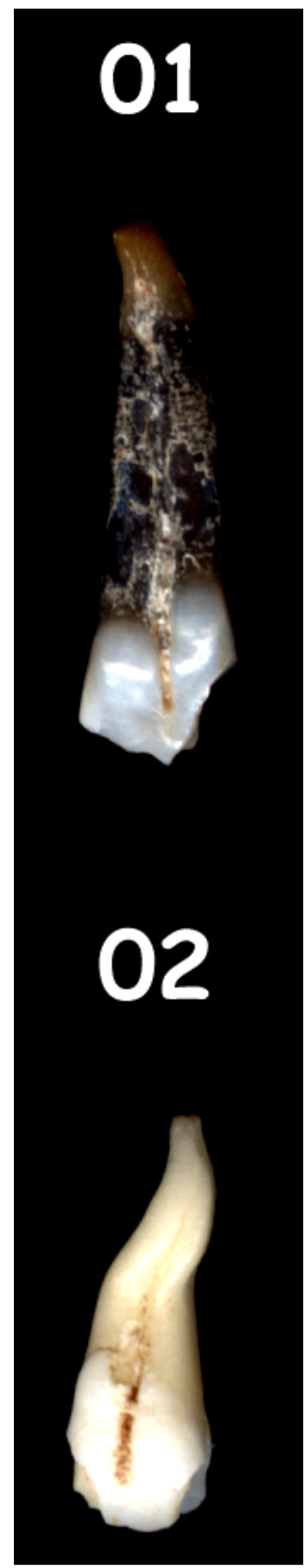

\section{Espécime $\mathrm{n}^{\circ} \mathbf{1}$ - incisivo lateral superior direito}

> O espécime apresenta o sulco palatogengival, com morfologia de sulco ou ruga, que se inicia na fossa lingual, estendendo-se ao terço apical, acompanhando a anatomia radicular. O sulco está localizado no centro da raiz e divide a superfície radicular em duas porções, uma mesial e outra distal. A junção amelocementária apresenta-se com formação de degrau. Outras alterações devem ser relevadas como a presença de cálculo aderido à raiz, principalmente no trajeto do sulco da porção coronária ao terço médio da raiz, fratura coronária e discreta dilaceração apical. A raiz apresenta-se ainda enegrecida da região cervical até o terço apical.

\section{Espécime $\mathrm{n}^{\circ} \mathbf{2}$ - incisivo lateral superior esquerdo}

$>$ O sulco palatogengival deste espécime possui a morfologia de fissura, com origem no cíngulo próximo à crista mesial; nesta região, essa fissura apresenta-se profunda, o sulco se estende ao terço apical, tornandose, então, mais como uma ruga. Localizado na porção central da raiz, como no espécime anterior, o sulco acompanha a anatomia do dente, dividindo a face lingual em partes mesial e distal. A junção amelocementária deste dente possui continuidade em seu trajeto. Notou-se ainda uma dilaceração radicular do tipo baioneta, cáries proximais e cálculo na porção coronária do sulco.

Figura 17 - Analise morfológica dos espécimes 1 e 2 


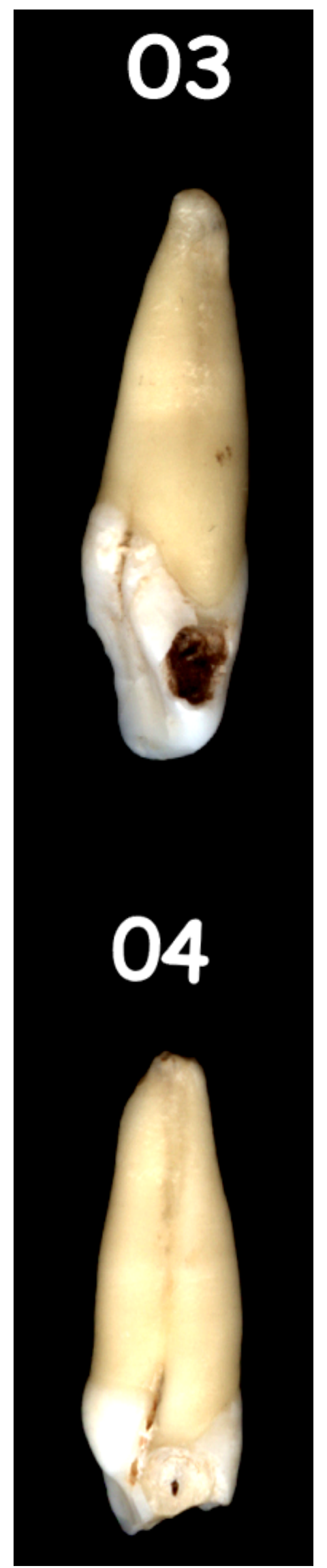

Espécime $\mathbf{n}^{\circ} \mathbf{3}$ - incisivo lateral superior esquerdo

> Este espécime possui o sulco palatogengival com forma de depressão profunda próxima à face distal do dente. A origem do defeito é no cíngulo, na crista marginal distal, desaparecendo à medida que se estende verticalmente ao terço médio do dente em sua face distal. A junção amelocementária encontrase descontínua, com degrau. Este espécime também possui uma discreta dilaceração apical para distal e, ainda, cáries nas faces proximais. O forame apical está alargado, com forma elíptica, devido a uma provável reabsorção apical.

\section{Espécime $n^{\circ} \mathbf{4}$ - incisivo lateral superior esquerdo} $>\quad$ O sulco palatogengival apresenta a forma de sulco ou ruga neste espécime. $O$ defeito inicia-se no cíngulo próximo à crista marginal distal, muito profundo, estende-se verticalmente até o ápice dentário, pela face distal do dente, acompanhando sua anatomia e dividindo a face distal numa porção vestibular, mais pronunciada, e numa porção palatina. A junção amelocementária está interrompida por um degrau na região do sulco. Notou-se um outro sulco mais raso na face mesial do dente. Os dois sulcos promovem o achatamento da raiz, no sentido mesiodistal, como se a raiz do dente estivesse a formar uma outra, acessória. $O$ dente apresenta cáries em suas faces proximais.

Figura 18 - Aspectos morfológicos dos espécimes 3 e 4 




\section{Espécime $\mathbf{n}^{\circ} 5$ - incisivo lateral superior direito}

$>\quad \mathrm{O}$ dente apresenta o sulco palatogengival com morfologia de sulco ou ruga pouco profunda, com início na região do cíngulo, próximo à crista marginal distal, extensão vertical até o início do terço apical na face distal do dente. A junção amelocementária apresenta um grande deslocamento do tipo degrau, onde o sulco a atravessa. No final do sulco observa-se, indicada pela seta azul uma foramina lateral. Deste ponto até o ápice do dente é possível identificar grande área irregular na superfície radicular, causado por reabsorções apicais. Estas reabsorções causaram o alargamento de forma irregular do forame apical. Nota-se ainda cárie no cíngulo e nas proximais do dente.

\section{Espécime $\mathbf{n}^{\circ} \mathbf{6}$ - incisivo lateral superior direito}

> Neste espécime, o sulco palatogengival está localizado na face mesial. Tem forma de depressão rasa, que parte da região do cíngulo próximo à crista marginal mesial, estende-se verticalmente até o terço apical, percorrendo a face mesial, acompanhando a anatomia do dente e dividindo-a em duas partes, uma vestibular, mais proeminente, e outra palatina. Devido à destruição por cárie da junção amelocementária no local onde esta é atravessada pelo sulco, não se pode afirmar se a junção sofreu alguma descontinuidade causada pelo defeito. Nota-se ainda uma restauração de amálgama na depressão do cíngulo na face lingual do espécime.

Figura 19 - Aspectos morfológicos dos espécimes 5 e 6 


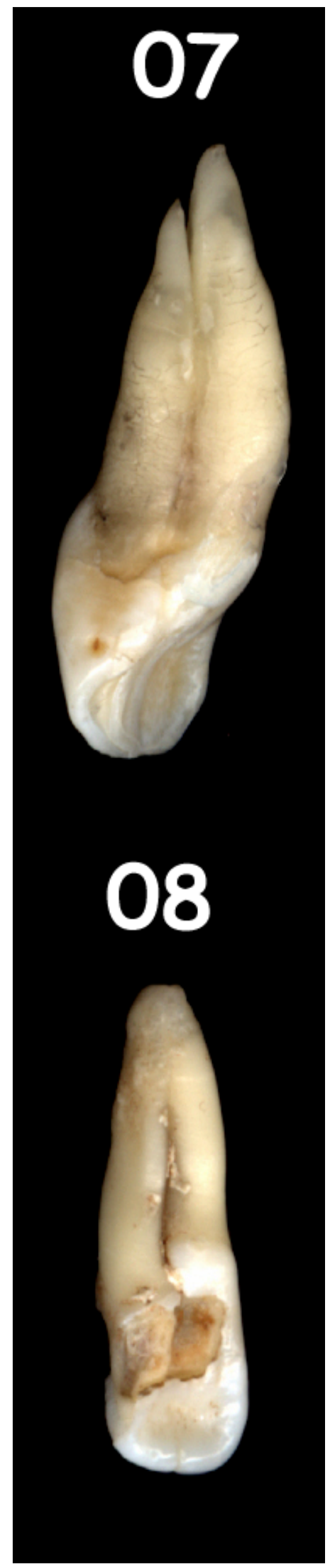

\section{Espécime $n^{\circ} 7$ - incisivo central superior direito}

$>\quad$ O sulco tem morfologia de fissura rasa neste espécime, localizado na face distal, inicia-se na crista marginal distal, próximo ao cíngulo, até o terço apical onde a fissura promove a formação de uma raiz acessória. A face distal encontra-se divida em duas partes, com uma porção radicular palatina mais robusta e outra vestibular, que termina num ápice fino e delicado. A junção amelocementária apresenta-se contínua. Na face vestibular um outro sulco, vestibular-vertical, percorre uma trajetória semelhante ao palatogengival, iniciando-se no terço médio da coroa, seguindo verticalmente ao terço apical, onde as raízes se separam.

\section{Espécime $\mathbf{n}^{\circ} 8$ - incisivo lateral superior direito}

$>\quad O$ dente correspondente ao espécime $n^{\circ} 8$ possui o sulco palatogengival com forma de fissura profunda, que se inicia na crista marginal distal, próximo ao cíngulo, e desaparece à medida que se estende verticalmente para o terço médio do dente. O defeito localiza-se na divisão entre a face palatina e a face distal. A junção amelocementária não pode ser identificada em parte da área onde o sulco a atravessa, devido à presença de cárie que arrebata toda a vestibular, distal e palatina da coroa do dente. Nota-se, ainda, a presença de cálculo aderido ao sulco na cervical e no terço médio do espécime. No ápice reabsorvido, algumas foraminas encontram-se periféricas ao forame apical.

Figura 20 - Aspectos morfológicos dos espécimes 7 e 8 


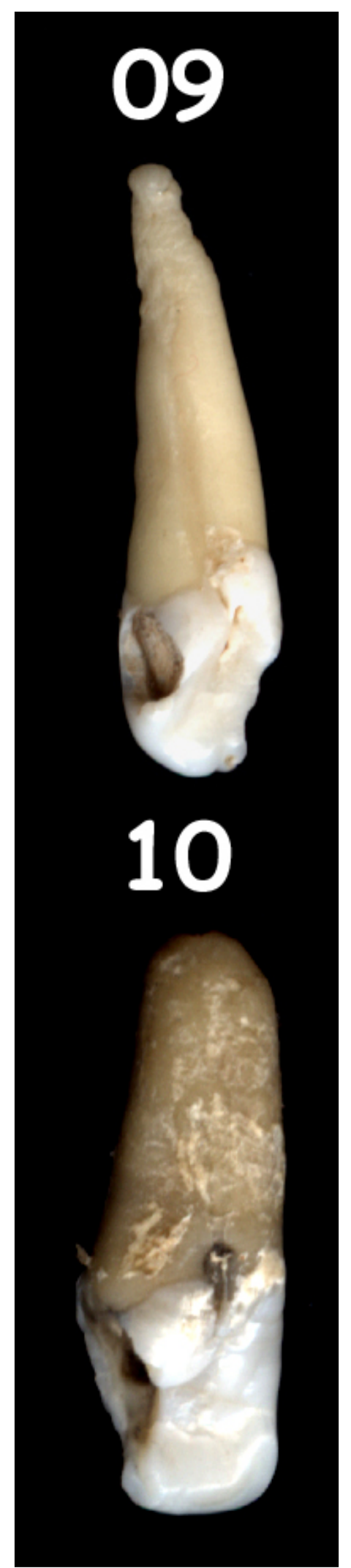

\section{Espécime $\mathbf{n}^{\circ} \mathbf{9}$ - incisivo lateral superior direito}

No espécime ao lado, o sulco palatogengival começa na fossa lingual, segue apicalmente pela crista marginal distal, onde atravessa a junção amelocementária, interrompendo-a em degrau, continua verticalmente acompanhando a anatomia do dente até a intercessão entre o terço médio e o apical. Todo o trajeto pela raiz ocorre em sua face distal. Com o desaparecimento do sulco inicia-se uma grande área de reabsorção radicular, que se estende até o ápice do dente, tornando irregular a superfície dessa região. Observou-se, ainda, hipoplasia adamantina na vestibular, cárie nas faces proximais coronárias e dilaceração radicular.

\section{Espécime $\mathrm{n}^{\circ} 10$ - incisivo central superior direito}

$>\quad$ Este espécime apresenta o sulco tal qual uma depressão rasa, com início na fossa lingual e extensão vertical até o terço apical do dente. O sulco palatogengival está bem centralizado na face palatina, dividindo-a em duas partes, uma mesial, mais proeminente, e outra lingual. A interrupção em forma de degrau na junção amelocementária apresenta-se pigmentada e repleta de cálculo aderido à sua superfície. O dente apresenta ainda cárie na face distal da coroa, bem como depósitos de cálculo por toda a superfície radicular, comprometendo também áreas de esmalte coronário nas faces vestibular e palatina. O ápice dentário possui áreas de reabsorção com decorrente alargamento do forame apical.

Figura 21 - Aspectos morfológicos dos espécimes 9 e 10 


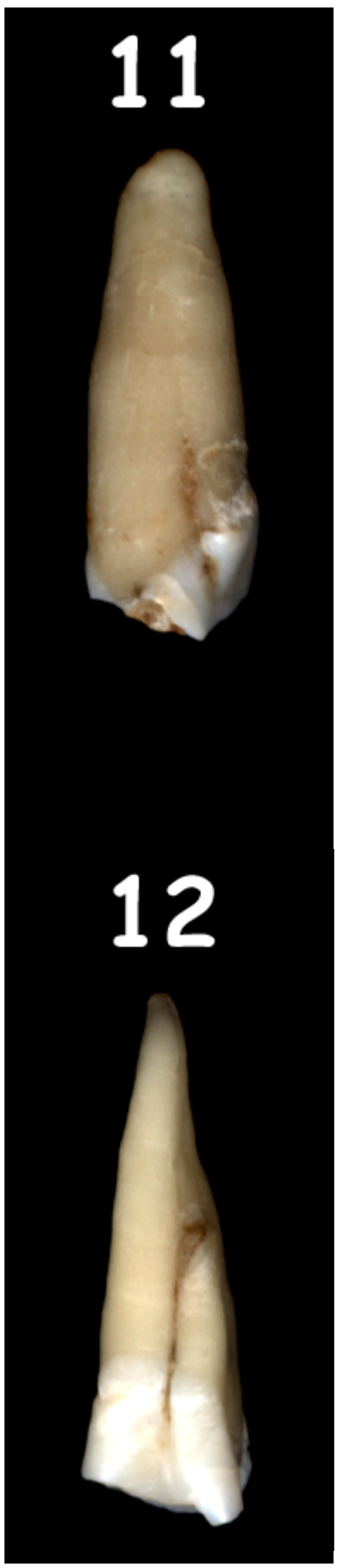

\section{Espécime $\mathbf{n}^{\circ} 11$ - incisivo lateral superior direito \\ Este espécime apresenta o sulco} palatogengival em forma de sulco ou ruga que se inicia no cíngulo, próximo à crista marginal distal. Após atravessar a junção amelocementária, interrompendo-a em degrau, o sulco estende-se verticalmente até desaparecer no terço médio radicular. O defeito situa-se na região entre as faces palatina e distal da raiz, agindo como limite entre as mesmas. A coroa do dente aparenta ter-se fraturado, devido ao comprometimento pela cárie que afeta a distal coronária. Observa-se ainda a presença de cálculo aderido à cervical palatina subjacente à junção amelocementária.

\section{Espécime $n^{\circ} 12$ - incisivo lateral superior esquerdo}

$>$ O espécime possui o sulco com morfotipo de fissura profunda, se inicia no cíngulo, próximo à crista marginal distal, e segue até o terço médio do dente. A fissura divide a face lingual dentária em duas porções, uma mesial, longa e robusta, outra distal, que termina junto ao sulco. A parte distal da raiz parece formar uma raiz acessória, ou um apêndice, com sua extremidade apical fraturada, revelando um canalículo acessório em seu interior. A junção amelocementária neste espécime é interrompida formando um pequeno degrau. $\mathrm{O}$ dente apresenta ainda a coroa fraturada por cárie proximal e um ápice dilacerado e fino.

Figura 22 - Aspectos morfológicos dos espécimes 11 e 12 


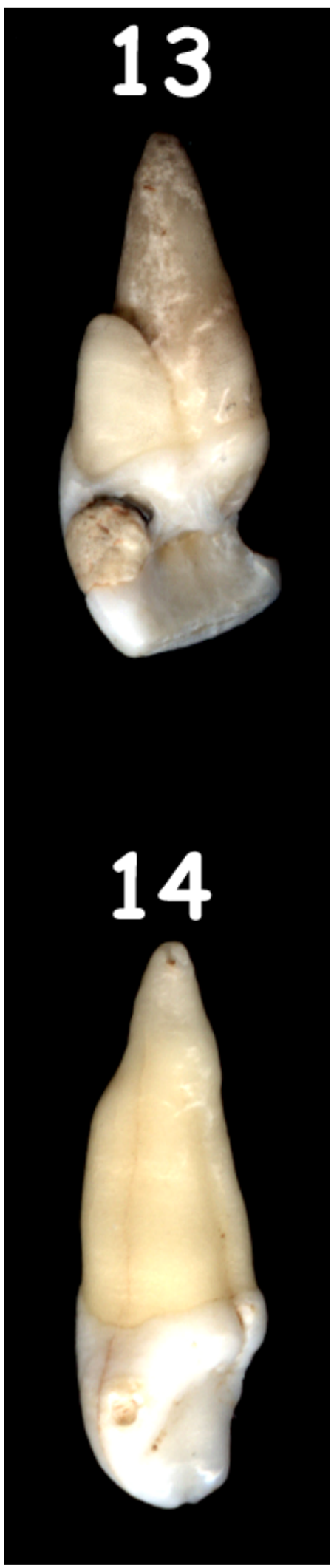

\section{Espécime $n^{\circ} 13$ - incisivo central superior direito}

$>\quad$ O sulco tem início na crista marginal distal, próximo ao cíngulo com morfologia de sulco ou ruga. Estende-se apicalmente até o terço médio do dente, associando-se à um apêndice radicular ou raiz acessória. A face vestibular também possui um sulco vestibular vertical que, como o sulco palatogengival, interrompe a junção amelocementária, formando um discreto degrau. A grande porção radicular mesial ao sulco apresenta extensa área de reabsorção, envolvendo a região, disposta a partir do término do sulco até o ápice radicular. Notam-se, ainda, cárie nas proximais do dente e uma restauração de cimento de silicato na face distal, que se apresenta mal adaptada.

\section{Espécime $n^{\circ} 14$ - incisivo lateral superior direito}

$>$ O sulco palatogengival do espécime $\mathrm{n}^{\circ} 14$ tem a forma de sulco ou ruga. Inicia-se na fossa lingual e se direciona verticalmente à região intermediária entre o terço médio e apical. A face palatina é dividida em duas porções, uma mesial, mais delgada, e outra, a distal, robusta e pouco proeminente. A junção amelocementária é contínua na face lingual. A raiz apresenta, ainda, dilaceração em seu terço apical em forma de baioneta. A coroa do dente foi parcialmente destruída por cárie na face mesial do dente.

Figura 23 - Aspectos morfológicos dos espécimes 13 e 14 


\section{5}

Espécime $\mathrm{n}^{\circ} 15$ - incisivo central superior esquerdo

$>\quad$ Um sulco profundo se destaca neste espécime, iniciando-se no cíngulo, próximo à crista marginal distal, e desaparecendo, em seguida, no terço médio radicular. O sulco se estende pela distal do dente como um limite entre essa face e a palatina. A junção amelocementária possui um degrau com formações calcárias aderidas, devido à superfície irregular da região onde o sulco a interrompe. A cavidade pulpar comunica-se com o meio externo devido a uma extensa destruição por cárie na coroa enegrecida do dente.

\section{Espécime $\mathrm{n}^{\circ} 16$ - incisivo lateral superior esquerdo}

> O sulco apresenta-se profundo, porém breve, neste espécime. Iniciando-se no cíngulo, próximo à 16 crista marginal distal, percorre uma trajetória vertical até o terço médio, diminuindo progressivamente sua profundidade a ponto de desaparecer como uma leve depressão. A junção amelocementária perde sua continuidade com a parte mesial do cíngulo muito pronunciada, formando um degrau no seu contorno. $O$ dente tem a coroa fraturada a ponto de expor 0 compartimento pulpar ao meio externo. O ápice radicular apresenta dilaceração, com um forame apical largo, apesar de delicado.

Figura 24 - Aspectos morfológicos dos espécimes 15 e 16 


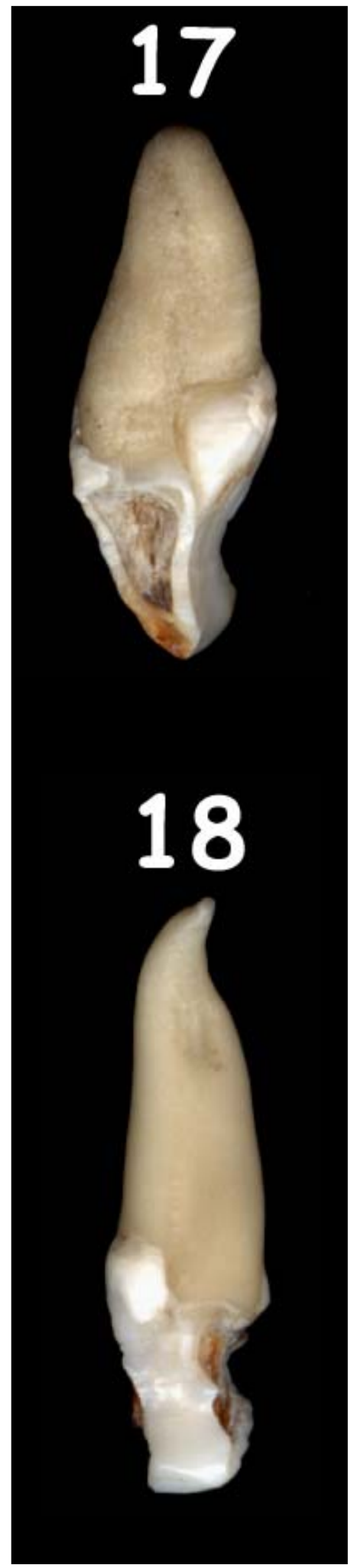

\section{Espécime $n^{\circ} 17$ - incisivo central superior direito}

$>$ Com forma de depressão profunda, o sulco palatogengival deste dente tem início na crista marginal distal e segue verticalmente até o ápice, pela face distal, dividindo-a em duas partes, uma vestibular bem pronunciada e outra, a palatina, que segue o contorno anatômico radicular. Um grande degrau se insinua na junção amelocementária. O espécime possui a raiz curta, a coroa com extensa hipoplasia adamantina nas faces vestibular e lingual, além de cárie nas proximais.

\section{Espécime $n^{\circ} 18$ - incisivo lateral superior esquerdo}

> O incisivo ao lado apresenta o defeito em forma de uma depressão bem acentuada, iniciada na fossa lingual, e extensa, alcançando o terço apical do dente. O sulco palatogengival altera a anatomia radicular do espécime, devido ao achatamento no sentido proximal, complementado por outra depressão na face mesial do dente. A junção possui um degrau que interrompe sua continuidade. No cíngulo uma pequena cúspide se pronuncia adjacente ao sulco. A coroa expõe grande destruição por cárie em todas as suas faces. O terço apical da raiz manifesta-se dilacerado, com o ápice bastante fino e delicado.

Figura 25 - Aspectos morfológicos dos espécimes 17 e 18 




\section{Espécime $n^{\circ} 19$ - incisivo lateral superior direito}

No espécime 19, o defeito apresenta a forma de sulco profundo, partindo do cíngulo, próximo à crista marginal distal, progride verticalmente em direção ao terço apical pela face distal radicular, onde sua forma mais se assemelha a uma leve depressão. A junção amelocementária apresenta um degrau, perdendo sua continuidade na região onde é atravessada pelo sulco. Observase ainda o acúmulo de cálculo dentário nas porções cervical e média do espécime. Uma lesão cariosa compromete a face distal causando uma discreta comunicação entre a câmara pulpar e o meio externo.

\section{Espécime $\mathbf{n}^{\circ} 20$ - incisivo lateral superior esquerdo}

$>\quad O$ sulco palatogengival tem forma de fissura profunda no cíngulo e na crista marginal distal. Atravessa a junção amelocementária, interrompendo-a. Em seguida, a profundidade do defeito diminui, ao passo que progride verticalmente em direção apical, desaparecendo como uma rasa depressão no terço apical do dente. A face distal da raiz é dividida pelo sulco em duas porções, uma vestibular e outra palatina. O terço apical radicular também se manifesta dilacerado. Observa-se, ainda, lesão não cariosa na cervical vestibular e uma restauração provisória infiltrada por cárie na face mesial da coroa.

Figura 26 - Aspectos morfológicos dos espécimes 19 e 20 
Todas as informações morfológicas referentes ao exame macroscópico e estereomicroscópico foram tabuladas como pode ser observado a seguir:

Tabela 9 - Distribuição dos achados característicos da presença do sulco palatogengival entre os 20 dentes avaliados morfologicamente

\begin{tabular}{|c|c|c|c|c|c|c|c|c|c|c|c|c|}
\hline \multicolumn{2}{|c|}{ Espécimes } & 01 & 02 & 03 & 04 & 05 & 06 & 07 & 08 & 09 & 10 & subtotal \\
\hline \multirow{3}{*}{$\begin{array}{l}\text { Morfologia } \\
\text { do sulco }\end{array}$} & Depressão & & & $x$ & & & $x$ & & & & $x$ & 3 \\
\hline & Ruga & $x$ & & & $x$ & $x$ & & & & $x$ & & 4 \\
\hline & Fissura & & $x$ & & & & & $x$ & $x$ & & & 3 \\
\hline \multirow{3}{*}{$\begin{array}{l}\text { Início do sulco } \\
\text { na coroa }\end{array}$} & Fossa & $x$ & & & & & & & & $x$ & $x$ & 3 \\
\hline & Crista mesial & & $x$ & & & & $x$ & & & & & 2 \\
\hline & Crista distal & & & $x$ & $x$ & $x$ & & $x$ & $x$ & & & 5 \\
\hline \multirow{3}{*}{$\begin{array}{l}\text { Extensão além } \\
\text { da junção } \\
\text { amelocementária }\end{array}$} & $1 / 3$ cervical & & & & & & & & & & & 0 \\
\hline & 1/3 médio & & & $x$ & & & & & $x$ & $x$ & & 3 \\
\hline & 1/3 apical & $x$ & $x$ & & $x$ & $x$ & $x$ & $x$ & & & $x$ & 7 \\
\hline \multirow{3}{*}{$\begin{array}{l}\text { Localização na } \\
\quad \text { raiz }\end{array}$} & Palatina & $x$ & $x$ & & & & & & & & $x$ & 3 \\
\hline & Mesial & & & & & & $x$ & & & & & 1 \\
\hline & Distal & & & $x$ & $x$ & $x$ & & $x$ & $x$ & $x$ & & 6 \\
\hline \multirow{3}{*}{$\begin{array}{l}\text { Trajeto da junção } \\
\text { amelocementária }\end{array}$} & Degrau & $x$ & & $x$ & $x$ & $x$ & & & & $x$ & $x$ & 6 \\
\hline & Contínua & & $x$ & & & & & $x$ & & & & 2 \\
\hline & Alterada & & & & & & $x$ & & $x$ & & & 2 \\
\hline
\end{tabular}


Tabela 9 - Continuação

\begin{tabular}{|c|c|c|c|c|c|c|c|c|c|c|c|c|}
\hline \multicolumn{2}{|c|}{ Espécimes } & 11 & 12 & 13 & 14 & 15 & 16 & 17 & 18 & 19 & 20 & total \\
\hline \multirow{3}{*}{$\begin{array}{l}\text { Morfologia } \\
\text { do sulco }\end{array}$} & Depressão & & & & & & & $x$ & $x$ & & & 5 \\
\hline & Ruga & $x$ & & $x$ & $x$ & $x$ & $x$ & & & $x$ & & 10 \\
\hline & Fissura & & $x$ & & & & & & & & $x$ & 5 \\
\hline \multirow{3}{*}{$\begin{array}{l}\text { Início do sulco } \\
\text { na coroa }\end{array}$} & Fossa & & & & $x$ & & & & $x$ & & & 5 \\
\hline & Crista mesial & & & & & & & & & & & 2 \\
\hline & Crista distal & $x$ & $x$ & $x$ & & $x$ & $x$ & $x$ & & $x$ & $x$ & 13 \\
\hline \multirow{3}{*}{$\begin{array}{l}\text { Extensão além } \\
\text { da junção } \\
\text { amelocementária }\end{array}$} & $1 / 3$ cervical & & & & & & & & & $x$ & & 1 \\
\hline & 1/3 médio & $x$ & $x$ & $x$ & $x$ & $x$ & $x$ & & & & & 9 \\
\hline & 1/3 apical & & & & & & & $x$ & $x$ & & $x$ & 10 \\
\hline \multirow{3}{*}{$\begin{array}{l}\text { Localização na } \\
\quad \text { raiz }\end{array}$} & Palatina & & & & $x$ & & & & & & & 4 \\
\hline & Mesial & & & & & & & & $x$ & & & 2 \\
\hline & Distal & $x$ & $x$ & $x$ & & $x$ & $x$ & $x$ & & $x$ & $x$ & 14 \\
\hline \multirow{3}{*}{$\begin{array}{l}\text { Trajeto da junção } \\
\text { amelocementária }\end{array}$} & Degrau & $x$ & $x$ & $x$ & & $x$ & $x$ & $x$ & $x$ & $x$ & $x$ & 15 \\
\hline & Contínua & & & & $x$ & & & & & & & 3 \\
\hline & Alterada & & & & & & & & & & & 2 \\
\hline
\end{tabular}

\subsubsection{Análise radiográfica}

Com a análise radiográfica dos 15 incisivos laterais superiores e 5 incisivos centrais superiores da amostra, foi possível confirmar a ausência de tratamento endodôntico nestes dentes. O sulco palatogengival não pode ser identificado radiograficamente em apenas dois espécimes ( $n^{0} 1$ e $n^{014}$ ) através das tomadas radiográficas periapicais ortorradiais. Nestes espécimes o sulco era raso e com pouca extensão. Ainda no espécime $n^{\circ} 1$, o canal principal demonstrou aspecto de atresia de seu leito. O dente n 05 apresentou uma 
pequena estrutura radiopaca compatível com um nódulo pulpar no terço apical da raiz. O espécime $n^{\circ} 6$ apresentou área radiopaca localizada na região do cíngulo, compatível com a restauração de amálgama descrita na análise macroscópica e estereomicroscópica. Apenas o espécime $\mathrm{n}^{07}$ apresentou dois canais identificáveis radiograficamente, trata-se de um canal acessório que tem início no terço médio da raiz e continua seu trajeto dentro da raiz acessória. Abaixo estão dispostos os espécimes na mesma seqüência apresentada na análise macroscópica.

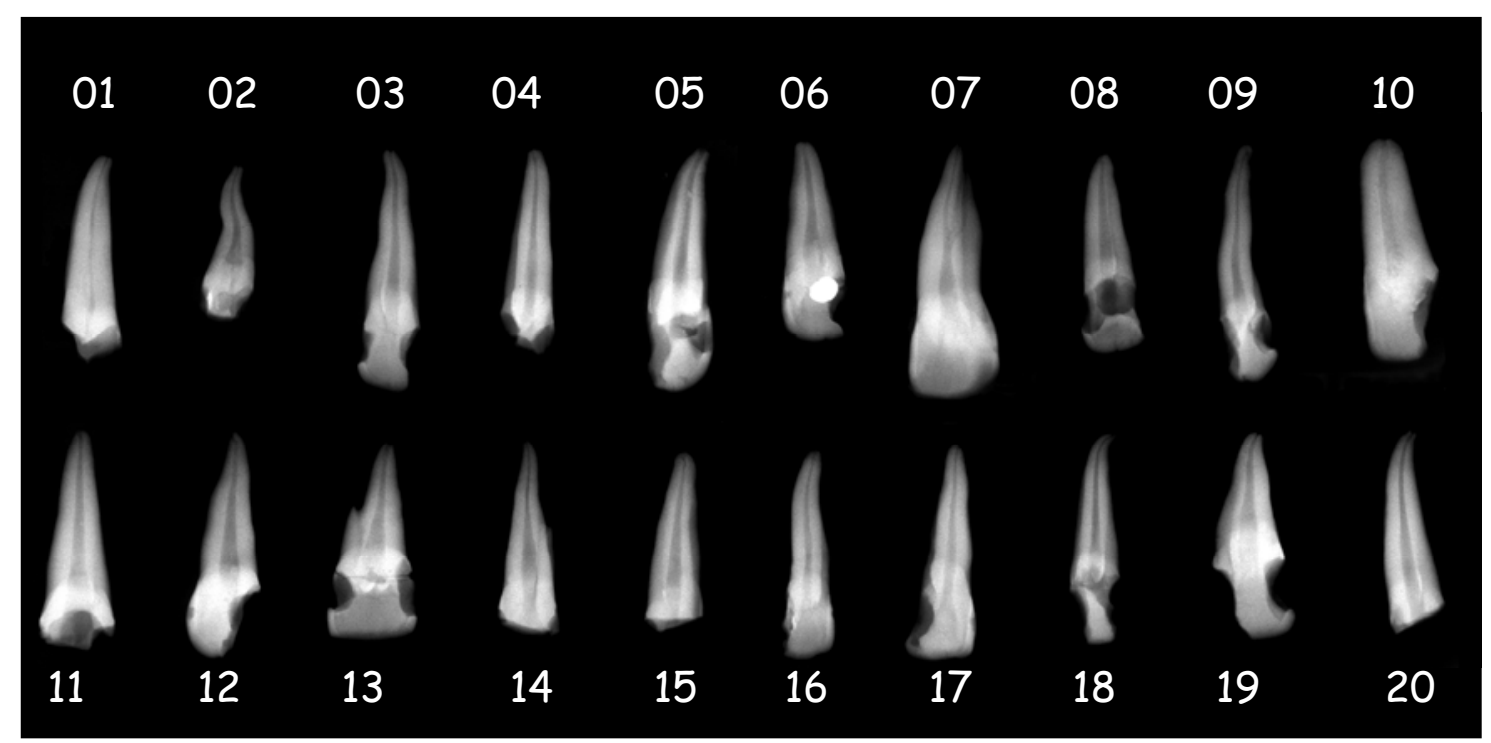

Figura 27 - Visão geral da análise da radiográfica da amostra antes do preparo para microscopia eletrônica de varredura

\subsubsection{Análise da superfície radicular e coronária do sulco palatogengival à microscopia eletrônica de varredura}

Após avaliados macroscópica, estereomicroscópica e radiograficamente, os espécimes foram metalizados para análise das superfícies radicular e coronária alteradas pela presença do sulco palatogengival. Durante a análise, os espécimes foram caracterizados quanto à presença de cálculo relacionado ao sulco; a relação do sulco com possíveis forames, foraminas e túbulos 
dentinários expostos em seu leito que comunicassem o compartimento pulpar com o compartimento periodontal; o tipo de relação entre o esmalte e o cemento na junção amelocementária; e as possíveis alterações na junção, devido à presença do sulco.

Observaram-se ainda, nos dentes onde o sulco provocou uma raiz acessória, se havia também um segundo canal. Notou-se também a presença de reabsorção radicular externa em alguns espécimes, esta reabsorção foi caracterizada de acordo com sua localização: no 1/3 cervical, no 1/3 médio e no 1/3 apical da raiz.

A junção amelocementária apresentou alterações variáveis com a presença do sulco palatogengival. Em alguns espécimes, quando os sulcos eram muito profundos, sua identificação foi bastante dificultada, já em outros, o esmalte dentário foi respeitado pelo trajeto do sulco.

De um modo geral a presença de cálculo dentário aderido à superfície radicular e coronária apresentava-se localizados preferencialmente na região cervical, próximo à junção amelocementária, podendo, em alguns casos, estender-se apicalmente percorrendo o leito do sulco palatogengival.

Foram identificadas comunicações entre os compartimentos pulpar e periodontal em seis dos 20 espécimes avaliados. Essas comunicações eram túbulos dentinários foraminas ou forames laterais como o relatado anteriormente na análise macroscópica e estereomicroscópica do espécime $n^{\circ}$ 5. A seguir, estão dispostos os principais achados da microscopia eletrônica de varredura quanto à morfologia do sulco palatogengival na superfície radicular e coronária da amostra. 


\section{FIGURA 28}

Figura 28A - Características morfológicas comparativas do espécime n² à vista macroscópica e à microscopia eletrônica de varredura. Nota-se indicado pela seta azul pontilhada o acúmulo de cálculo dentário na parte coronária do sulco palatogengival. As setas verdes indicam inúmeras áreas de reabsorção radicular na região cervical próximo à junção amelocementária

Figura 28B - No destaque magnificação do ápice radicular revela o forame apical bastante alterado pelo processo reabsortivo, o que provoca irregularidades em seu contorno, como destacado pela linha pontilhada azul. Notam-se ainda remanescentes teciduais do conteúdo pulpar no interior do canal

Figura 28C - Visão lateral do ápice radicular revela o sulco palatogengival estendendo-se em direção à região apical como uma leve depressão, seu leito está destacado pela linha pontilhada azul. As setas amarelas indicam inúmeras lacunas de Howship que promovem as irregularidades da superfície apical, algumas delas bem próximas ao sulco palatogengival, ou até envolvendo-o 


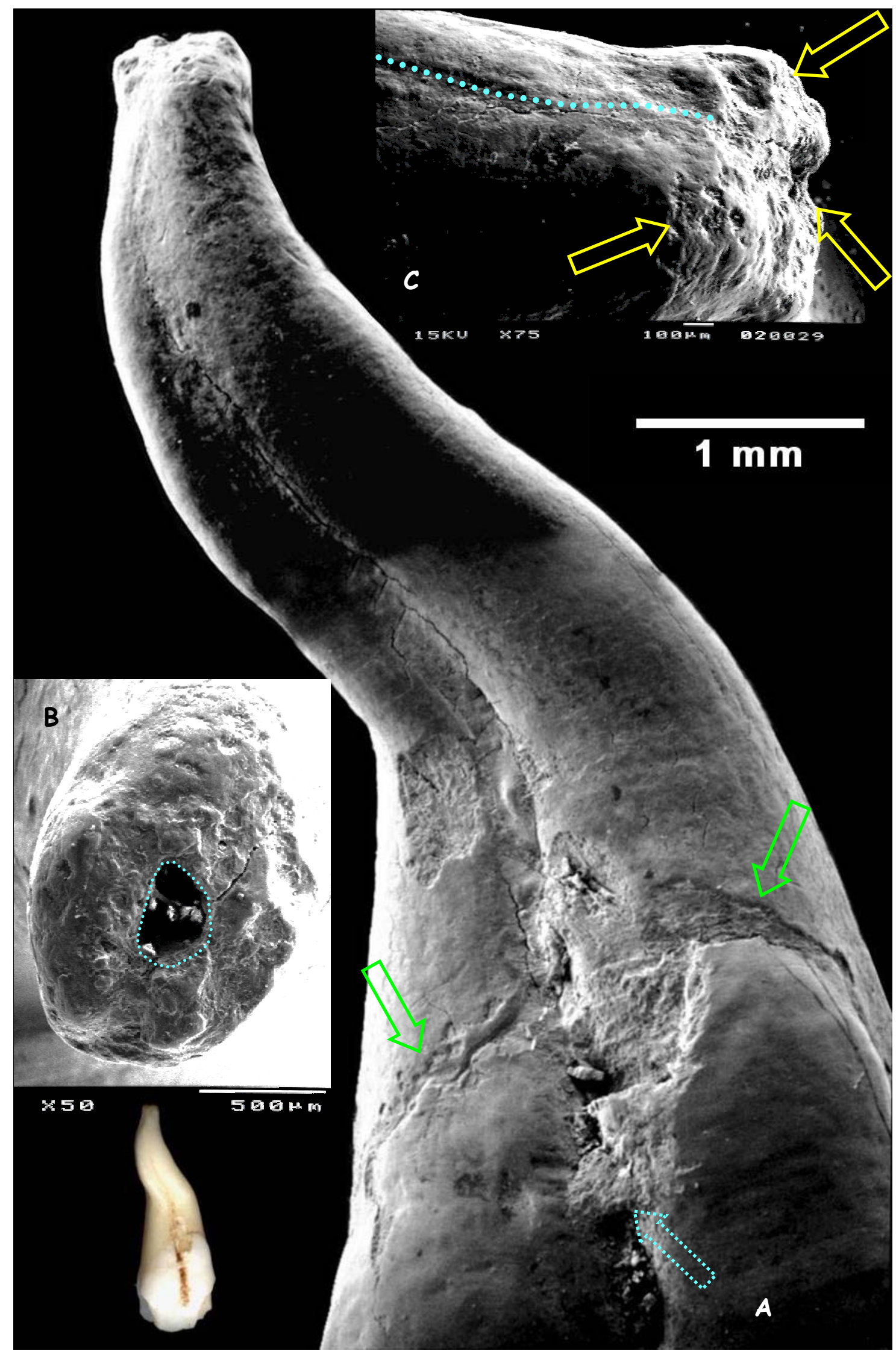




\section{FIGURA 29}

Figura 29A - Características morfológicas do espécime n5 com a fusão das vistas macroscópica e à microscopia eletrônica de varredura. Nota-se indicado pela linha azul pontilhada o degrau acentuado da junção amelocementária relacionado à presença do sulco palatogengival. A junção apresenta áreas onde o cemento recobre o esmalte, outras onde os tecidos relacionam-se topo a topo e ainda áreas onde existe uma relação do tipo "gap". Ainda no terço cervical da raiz, nota-se a presença de uma região compatível com reabsorção, próximo à junção amelocementária, indicado pela seta amarela. No final do terço médio ou início do terço apical da raiz, o sulco palatogengival praticamente desaparece, neste ponto, destacado pela seta azul, encontra-se um forame lateral. Já na região apical, a raiz apresenta inúmeras áreas com processo reabsortivo, deposição irregular de cemento e várias foraminas indicadas pelas setas verdes

Figura 29B - A magnificação do ápice radicular deste espécime, também revelou o forame apical bastante alterado pelo processo reabsortivo, seu contorno irregular, como destacado pela linha pontilhada azul tem a aparência semelhante a uma vírgula invertida. Notam-se ainda algumas foraminas acessórias mencionadas anteriormente se abrindo junto ao forame principal 


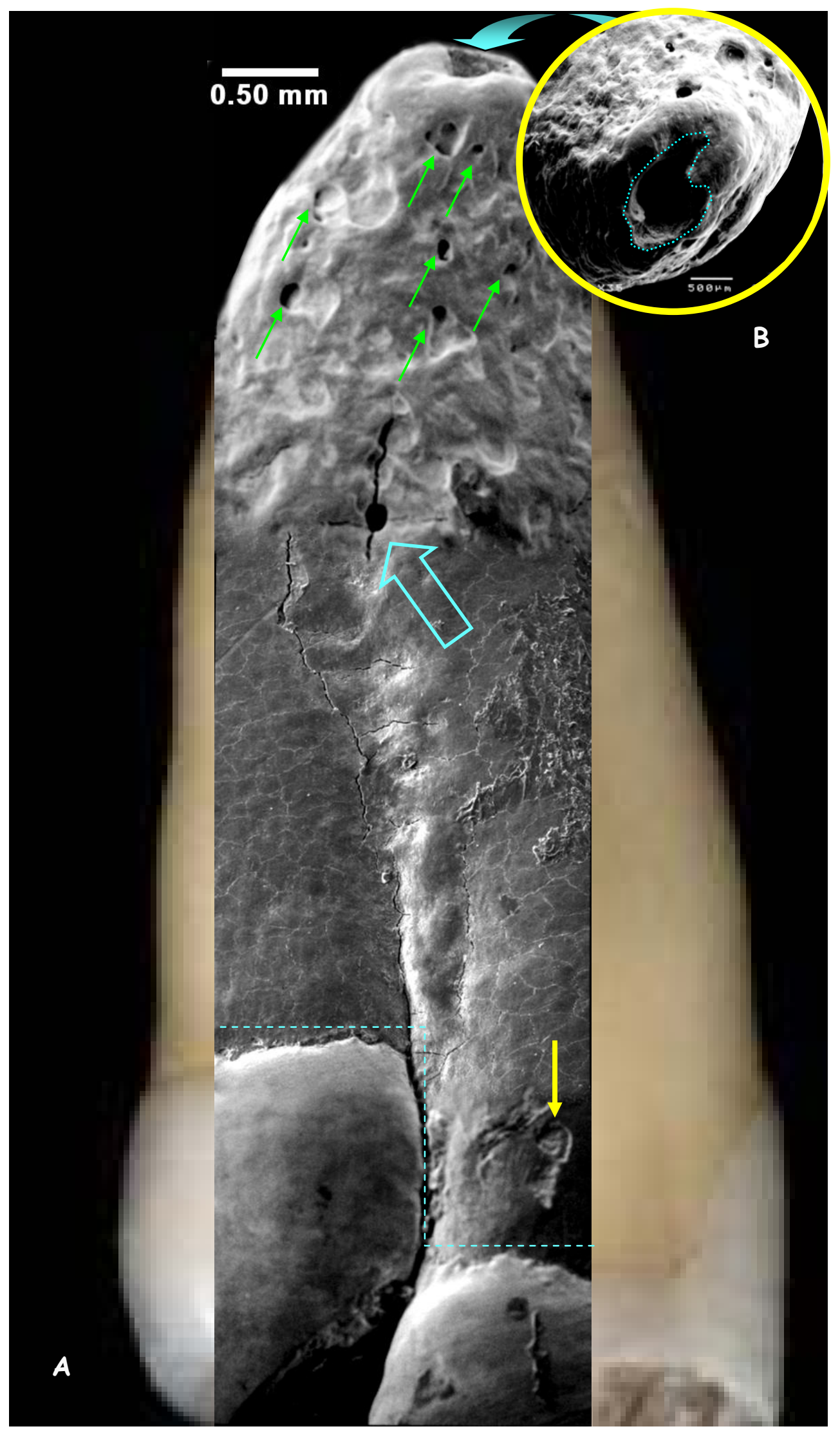




\section{FIGURA 30}

Figura 30A - Foi constatada no espécime $\mathrm{n}^{0} 14$ a continuidade da junção amelocementária na região cervical, pois o esmalte daquela área recobria o sulco palatogengival, que era pouco profundo, como indicado pela linha pontilhada azul

Figura 30B - O aumento da área cervical destaca a presença de cálculo dentário aderido ao leito do sulco palatogengival. Nota-se ainda o esmalte e o cemento se encontrando topo a topo praticamente por toda área registrada

Figura 30C - A magnificação do cálculo dentário revela uma estrutura irregular formada por aglomerados bacterianos mineralizados, tornando a região susceptível à formação de cárie ou instalação de doença periodontal

Figura 30D - No espécime $\mathrm{n}^{0} 12$ a junção amelocementária já se apresenta numa situação completamente diferente do caso anterior, é possível observar destacado pelas linhas tracejadas verdes, que a junção parece estar interrompida. O sulco palatogengival deste dente é tão profundo, que impede a visualização do fundo de seu leito

Figura 30E - Maior aumento da porção apical da raiz acessória em seu ápice fraturado. Observa-se também uma trinca no sentido longitudinal e o lume do canal radicular bastante constrito 


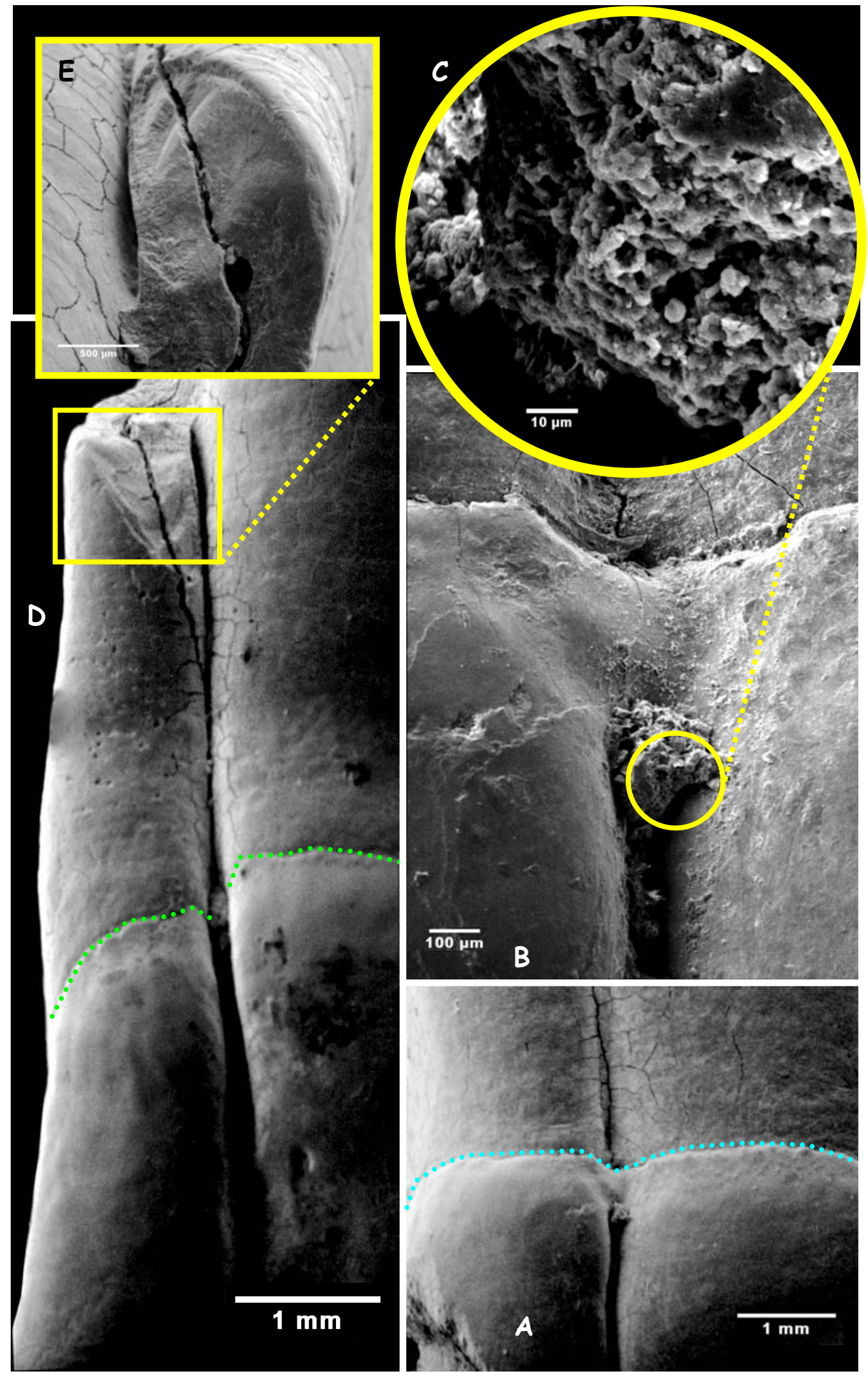


Um outro achado importante da análise da morfologia da superfície radicular e coronária dos dentes com sulco palatogengival foi a constatação de alterações na superfície do esmalte da região do sulco no espécime no 15 (figura 31). Essas alterações, localizadas no leito do sulco palatogengival, apresentavam aspecto semelhante à de um forame cego, podendo provavelmente representarem uma vista externa de uma invaginação de esmalte dentário tipo dente invaginado.

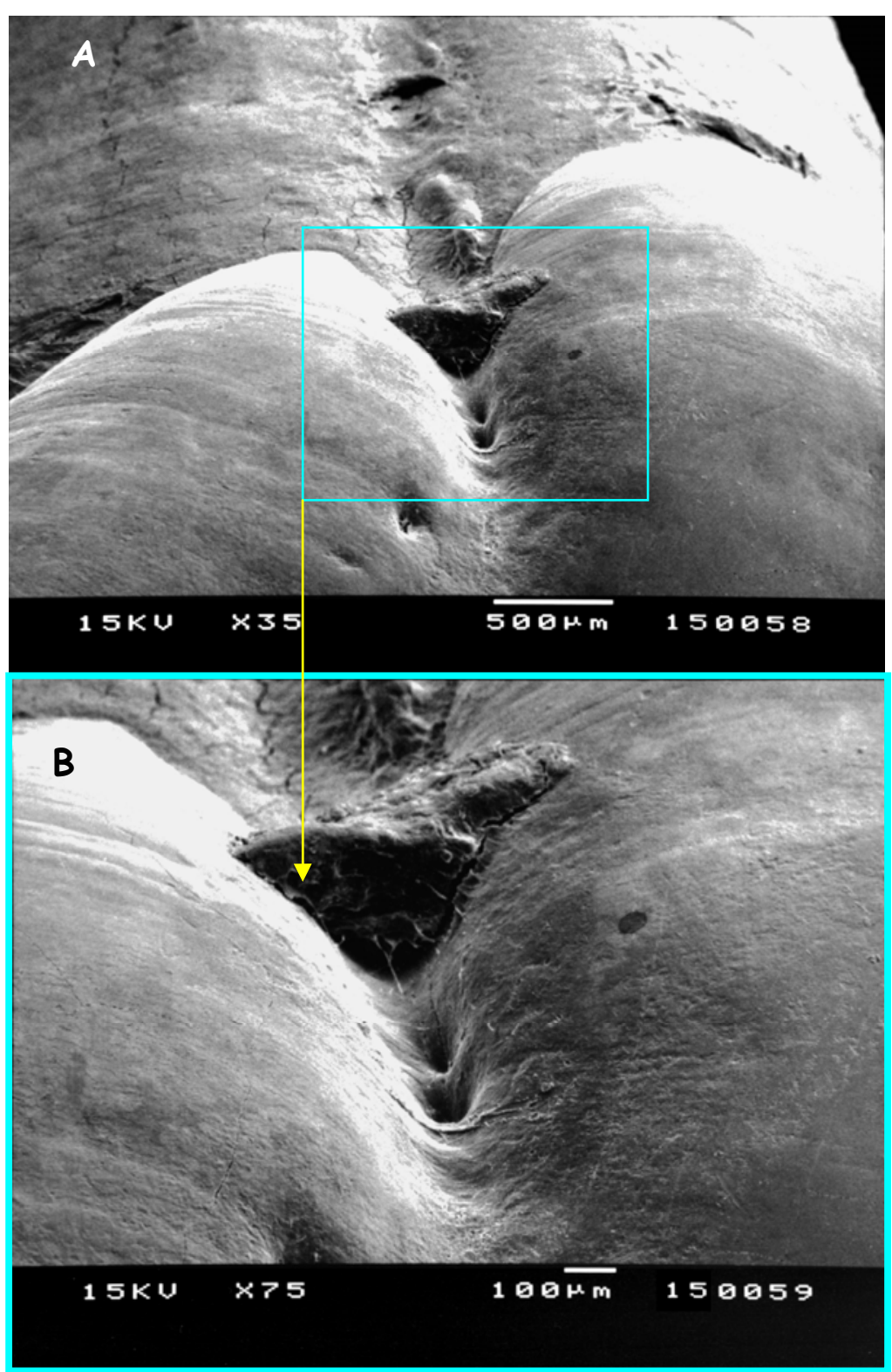

Figura 31 - Detalhes morfológicos do espécime $n^{\circ} 15$, onde uma possível invaginação do esmalte estava presente no leito do sulco palatogengival 
Todas as informações morfológicas referentes ao exame dos espécimes à microscopia eletrônica de varredura foram tabuladas com pode ser observado a seguir:

Tabela 10 - Distribuição das alterações relacionadas com a presença do sulco palatogengival na análise à microscopia eletrônica de varredura

\begin{tabular}{|c|c|c|c|c|c|c|c|c|}
\hline \multicolumn{3}{|c|}{ Espécimes } & 01 & 02 & 03 & 04 & 05 & subtotal \\
\hline \multirow{4}{*}{$\begin{array}{l}\text { Cálculo } \\
\text { dentário }\end{array}$} & \multirow{3}{*}{ presente } & coroa & & & & & $x$ & 1 \\
\hline & & junção & $x$ & $x$ & & $x$ & & 3 \\
\hline & & raiz & & & & & & 0 \\
\hline & \multicolumn{2}{|l|}{ ausente } & & & & $x$ & & 1 \\
\hline \multirow{3}{*}{$\begin{array}{c}\text { Comunicações } \\
\text { Polpo - } \\
\text { Periodontais }\end{array}$} & \multicolumn{2}{|l|}{ forames } & - & & - & - & $x$ & 1 \\
\hline & \multicolumn{2}{|l|}{ foraminas } & - & & - & - & $x$ & 1 \\
\hline & \multicolumn{2}{|c|}{ túbulos expostos } & - & $X$ & - & - & & 1 \\
\hline \multirow{3}{*}{$\begin{array}{c}\text { Tipo de junção } \\
\text { amelocementária }\end{array}$} & \multicolumn{2}{|c|}{ topo a topo } & $x$ & & $x$ & & $x$ & 3 \\
\hline & \multicolumn{2}{|l|}{ "gap" } & & & & & $x$ & 1 \\
\hline & \multicolumn{2}{|c|}{ cemento no esmalte } & & $x$ & & $x$ & & 2 \\
\hline \multirow{3}{*}{$\begin{array}{c}\text { Reabsorção } \\
\text { dentária }\end{array}$} & \multicolumn{2}{|c|}{$1 / 3$ cervical } & $x$ & $x$ & & - & $x$ & 3 \\
\hline & \multicolumn{2}{|l|}{$1 / 3$ médio } & $x$ & & $x$ & - & $x$ & 3 \\
\hline & \multicolumn{2}{|l|}{ 1/3 apical } & $x$ & & & - & $x$ & 2 \\
\hline
\end{tabular}

continua 
Tabela 10 - Continuação

\begin{tabular}{|c|c|c|c|c|c|c|c|c|}
\hline \multicolumn{3}{|c|}{ Espécimes } & 06 & 07 & 08 & 09 & 10 & subtotal \\
\hline \multirow{4}{*}{$\begin{array}{l}\text { Cálculo } \\
\text { dentário }\end{array}$} & \multirow{3}{*}{ presente } & coroa & $x$ & & $x$ & $x$ & & 4 \\
\hline & & junção & & & $x$ & $x$ & $x$ & 6 \\
\hline & & raiz & & & $x$ & & & 1 \\
\hline & \multicolumn{2}{|l|}{ ausente } & & $x$ & & & & 2 \\
\hline \multirow{3}{*}{$\begin{array}{c}\text { Comunicações } \\
\text { Polpo - } \\
\text { Periodontais }\end{array}$} & \multicolumn{2}{|l|}{ forames } & - & - & - & & - & 1 \\
\hline & \multicolumn{2}{|l|}{ foraminas } & - & - & - & $x$ & - & 2 \\
\hline & \multicolumn{2}{|c|}{ túbulos expostos } & - & - & - & & - & 1 \\
\hline \multirow{3}{*}{$\begin{array}{l}\text { Tipo de junção } \\
\text { amelocementária }\end{array}$} & \multicolumn{2}{|c|}{ topo a topo } & & & $x$ & & $x$ & 5 \\
\hline & \multicolumn{2}{|l|}{ "gap" } & & & & $x$ & & 2 \\
\hline & \multicolumn{2}{|c|}{ cemento no esmalte } & $x$ & $x$ & & & & 4 \\
\hline \multirow{3}{*}{$\begin{array}{c}\text { Reabsorção } \\
\text { dentária }\end{array}$} & \multicolumn{2}{|c|}{$1 / 3$ cervical } & & & - & & - & 3 \\
\hline & \multicolumn{2}{|l|}{$1 / 3$ médio } & & & - & & - & 3 \\
\hline & \multicolumn{2}{|l|}{$1 / 3$ apical } & $x$ & $x$ & - & $x$ & - & 5 \\
\hline
\end{tabular}

continua 
Tabela 10 - Continuação

\begin{tabular}{|c|c|c|c|c|c|c|c|c|}
\hline \multicolumn{3}{|c|}{ Espécimes } & 11 & 12 & 13 & 14 & 15 & subtotal \\
\hline \multirow{4}{*}{$\begin{array}{l}\text { Cálculo } \\
\text { dentário }\end{array}$} & \multirow{3}{*}{ presente } & coroa & & $x$ & & & $x$ & 6 \\
\hline & & junção & & $x$ & & & & 7 \\
\hline & & raiz & & $x$ & & & & 2 \\
\hline & \multicolumn{2}{|l|}{ ausente } & $x$ & & $x$ & $x$ & & 5 \\
\hline \multirow{3}{*}{$\begin{array}{c}\text { Comunicações } \\
\text { Polpo - } \\
\text { Periodontais }\end{array}$} & \multicolumn{2}{|l|}{ forames } & - & - & - & & - & 1 \\
\hline & \multicolumn{2}{|l|}{ foraminas } & - & - & - & $x$ & - & 3 \\
\hline & \multicolumn{2}{|c|}{ túbulos expostos } & - & - & - & & - & 1 \\
\hline \multirow{3}{*}{$\begin{array}{l}\text { Tipo de junção } \\
\text { amelocementária }\end{array}$} & \multicolumn{2}{|c|}{ topo a topo } & & & $x$ & $x$ & $x$ & 8 \\
\hline & \multicolumn{2}{|l|}{ "gap" } & $x$ & $x$ & & $x$ & & 5 \\
\hline & \multicolumn{2}{|c|}{ cemento no esmalte } & & & & & & 4 \\
\hline \multirow{3}{*}{$\begin{array}{c}\text { Reabsorção } \\
\text { dentária }\end{array}$} & \multicolumn{2}{|c|}{$1 / 3$ cervical } & - & $x$ & - & & - & 4 \\
\hline & \multicolumn{2}{|l|}{$1 / 3$ médio } & - & $x$ & - & $x$ & - & 5 \\
\hline & \multicolumn{2}{|l|}{ 1/3 apical } & - & $x$ & - & & - & 6 \\
\hline
\end{tabular}

continua 
Tabela 10 - Continuação

\begin{tabular}{|c|c|c|c|c|c|c|c|c|}
\hline \multicolumn{3}{|c|}{ Espécimes } & 16 & 17 & 18 & 19 & 20 & total \\
\hline \multirow{4}{*}{$\begin{array}{l}\text { Cálculo } \\
\text { dentário }\end{array}$} & \multirow{3}{*}{ presente } & coroa & $x$ & $x$ & & $x$ & & 9 \\
\hline & & junção & & & & $x$ & $x$ & 9 \\
\hline & & raiz & & & & $x$ & & 3 \\
\hline & \multicolumn{2}{|l|}{ ausente } & & & $\mathrm{x}$ & & & 6 \\
\hline \multirow{3}{*}{$\begin{array}{c}\text { Comunicações } \\
\text { Polpo - } \\
\text { Periodontais }\end{array}$} & \multicolumn{2}{|l|}{ forames } & - & & & - & - & 1 \\
\hline & \multicolumn{2}{|l|}{ foraminas } & - & & $x$ & - & - & 4 \\
\hline & \multicolumn{2}{|c|}{ túbulos expostos } & - & $x$ & & - & - & 2 \\
\hline \multirow{3}{*}{$\begin{array}{c}\text { Tipo de junção } \\
\text { amelocementária }\end{array}$} & \multicolumn{2}{|l|}{ topo a topo } & $\mathrm{X}$ & & & $x$ & $x$ & 11 \\
\hline & \multicolumn{2}{|l|}{ "gap" } & & & $x$ & & & 6 \\
\hline & \multicolumn{2}{|c|}{ cemento no esmalte } & & $x$ & & & & 5 \\
\hline \multirow{3}{*}{$\begin{array}{c}\text { Reabsorção } \\
\text { dentária }\end{array}$} & \multicolumn{2}{|l|}{$1 / 3$ cervical } & - & - & & - & - & 4 \\
\hline & \multicolumn{2}{|l|}{ 1/3 médio } & - & - & & - & - & 5 \\
\hline & \multicolumn{2}{|l|}{ 1/3 apical } & - & - & $x$ & - & - & 6 \\
\hline
\end{tabular}




\subsubsection{Análise das alterações morfológicas causadas pelo preparo biomecânico}

\subsubsection{Grupo controle}

Os achados a seguir serão considerados como controle para o processamento e análise da amostra experimental com os dentes portadores do sulco palatogengival. Partindo dessas observações anatômicas e metodológicas, os métodos de avaliação dos achados à microscopia eletrônica de varredura ficam bem estabelecidos e mais reproduzíveis.

Os fragmentos dentários analisados refletiam aspectos anatômicos específicos a cada tipo de dente, e ainda características comuns a todos os espécimes observados. A diversidade de achados pode assim ser subdividida em padrões inerentes ao dente analisado individualmente, relacionados ao tipo de dente (incisivo central superior, incisivo lateral superior, canino superior ou molar superior "C-shape") e as características decorrentes do tipo de análise, ou seja, o efeito das técnicas empregadas para o processamento dos espécimes que Ihes conferem características semelhantes quando observados à microscopia eletrônica. Assim, os tópicos a seguir reportam os achados, interpretando as características individuais de cada secção, tentando relacionálas com o tipo de dente observado e o conjunto dos espécimes .

a) Morfologia da secção radicular inerente ao tipo de dente analisado:

$>$ Incisivo central superior: Os incisivos analisados apresentaram o canal volumoso e centralizado na raiz, com forma arredondada, mais largo no sentido vestíbulo-lingual do que no sentido mesiodistal na porção cervical e média da raiz, tornando-se circular no terço apical. 
$>$ Incisivo lateral superior: Devido ao achatamento radicular no sentido mesiodistal, o compartimento pulpar dos dentes observados possuía a forma elíptica, estreita e irregular, já nos cortes feitos nos terços médio e apical revelaram a tendência do canal em tornar-se arredondado quanto mais próximo ao terço apical.

> Canino superior: A raiz dos espécimes analisados tinha o bordo vestibular mais largo e mais arredondado que o lingual. $\mathrm{O}$ compartimento pulpar é mais amplo e mais largo que o dos incisivos. Sua dimensão vestíbulo-lingual é maior que a mesiodistal.

> Molar superior "C-shape": Os espécimes demonstraram sua raiz em forma de " $\mathrm{C}$ " com um amplo sulco na face distolingual. O compartimento pulpar possui três canais curvos e estreitos que se aproximam, quase compondo um só canal no terço apical do dente.

b) Características decorrentes da metodologia empregada:

Ressecamento dos espécimes: Devido ao processamento prévio a metalização, realizado para remover a umidade dos espécimes, e o período em que o dente é novamente desidratado na câmara de vácuo do metalizador, observou-se a formação de trincas e rachaduras na estrutura dentária. As alterações decorrentes não impedem a análise dos espécimes, mas foram consideradas durante o processo para evitar incorrer em erros, distinguindo os fatos dos artefatos de técnica durante 0 processo analítico.

> Alterações de estruturas pela infiltração de resina: Alguns dos espécimes selecionados no estudo apresentaram características próprias como perda de áreas focais de cemento, trincas e até mesmo fratura de radicular. Constatou-se eventualmente nesses casos a presença de resina preenchendo tais defeitos. 


\subsubsection{Grupo experimental}

a) Morfologia dos canais radiculares antes do preparo biomecânico:

Os canais dos dentes avaliados possuíam forma arredondada em todos os incisivos centrais superiores e também em 11 dos 15 incisivos laterais superiores. A posição dos canais no interior da raiz seguiu o mesmo padrão descrito no grupo controle, tanto no caso dos incisivos centrais, quanto nos laterais. Foram detectados dois canais nos espécimes 7, 12 e 13, esses dentes possuíam duas raízes, porém os canais dos espécimes 12 e 13 só foram revelados com os cortes, pois não foi possível identificá-los durante a análise radiográfica. O espécime 13 possuía ainda um canal secundário identificado em sua secção apical. Os espécimes 5, 9 e 12 tinham canais com formato elíptico devido ao achatamento no sentido mesiodistal. O espécime 18 apresentou seu canal com formato triangular até o terço apical, onde então assumia a forma elíptica.

A alteração na forma dos canais não pode ser atribuída exclusivamente à presença do sulco palatogengival, o espécime $n^{0} 1$ possuía atresia em seu canal, além de um nódulo pulpar, essas características morfológicas são atribuídas à quantidade de agentes agressores que atuaram durante o período fisiológico deste dente. Foram observados nódulos ainda nos espécimes 5 e 19. O contorno dos canais antes do preparo biomecânico era regular exceto no terço apical dos espécimes n² e 11.

A avaliação da distância do fundo do leito do sulco palatogengival ao canal radicular antes do preparo biomecânico revelou sua maior medida no terço cervical do espécime $n^{\circ} 1,2,28 \mathrm{~mm}$, a menor distância encontrada nesse terço foi no espécime $n^{\circ} 4,1,11 \mathrm{~mm}$, a medida média das distâncias foi de $1,58 \mathrm{~mm}$ para o terço cervical. As medidas tomadas no terço médio revelaram também o espécime $\mathrm{n}^{\circ} 1$ com a maior distância entre o fundo do sulco e o canal radicular, 2,23mm, a menor medida foi observada no espécime $\mathrm{n}^{\circ} 8,1 \mathrm{~mm}$ e a 
medida média de $1,52 \mathrm{~mm}$. Já no terço apical a maior distância encontrada foi de $1,96 \mathrm{~mm}$ no espécime $\mathrm{n}^{\circ} 7$ e a menor $0,84 \mathrm{~mm}$ no espécime 12 , a média das medidas da distância nesse terço foi de $1,25 \mathrm{~mm}$ de espessura de dentina.

\section{b) Morfologia dos canais radiculares depois do preparo biomecânico:}

A instrumentação dos canais radiculares promoveu a remoção da camada interna de dentina dos canais proporcionando o alargamento e arredondamento do lume dos condutos. As áreas dos canais aumentaram revelando a efetividade do preparo biomecânico em todos os espécimes. O alargamento das paredes do canal, porém não foi uniforme quando consideramos os terços avaliados de um mesmo espécime ou comparando os vários espécimes. Esse desgaste variou de acordo com a anatomia prévia de cada canal. De uma forma geral as secções cervical e média dos canais foram a que apresentaram desgastes mais regulares, no terço apical de alguns espécimes detectou-se o desgaste preferencial de uma parede, ou ainda áreas que quase não sofreram a ação do instrumento, mas sem significância estatística $(p<0,05)$.

Nenhum dos espécimes preparados apresentou perfurações ou rasgos comunicando o compartimento pulpar com o periodontal, mesmo nas áreas onde a espessura de dentina era fina devido à presença do sulco palatogengival. Os espécimes que apresentavam nódulos pulpares antes do preparo biomecânico não exibiam tais estruturas depois da instrumentação.

Apenas um dos três espécimes com dois canais teve ambos os canais instrumentados. O espécime 12 apresentava a abertura de seu segundo canal na parede cervical distal do canal principal, apesar de muito atrésico. A lima 6 foi a primeira que conseguiu penetrar na abertura do canal. Foi possível realizar o alargamento deste conduto até a lima 20. A raiz acessória se estendia até o terço médio da raiz principal; neste ponto, a fratura do ápice e uma trinca que havia nesta região da raiz, permitiram a infiltração da resina, o que impossibilitou a progressão dos instrumentos. A dificuldade de localização 
da entrada do canal do espécime $n^{07}$, que se bifurcava na região limítrofe do terço médio e apical, impossibilitou sua instrumentação, mesmo com o précurvamento de limas e várias tomadas radiográficas utilizadas para auxiliar tal localização. Já o segundo canal do espécime 13 também não foi instrumentado por ser extremamente atrésico, sendo observado somente com o auxílio da microscopia eletrônica de varredura, o diâmetro de seu maior eixo era 100 $\mu \mathrm{m}$.

A espessura de dentina entre o fundo do leito do sulco palatogengival e o interior do canal radicular diminuiu em quase todas as secções de todos os espécimes. Houve, porém, algumas secções onde as medidas antes e depois do preparo permaneceram inalteradas como aferido nas secções cervicais dos espécimes: 5, 6, 10, 12 e 18; secção média do espécime 17 e apical do espécime 16.

A maior distância entre o canal e o fundo do sulco no terço cervical foi de $2 \mathrm{~mm}$ no espécime $\mathrm{n}^{\circ} 4$, a menor de $0,99 \mathrm{~mm}$ no espécime $\mathrm{n}^{\circ} 2$, a média da medida das distâncias foi de $1,47 \mathrm{~mm}$. A mensuração da espessura de dentina no terço médio teve a maior medida de $1,82 \mathrm{~mm}$ no espécime $\mathrm{n}^{0} 3$, a menor foi de $0,73 \mathrm{~mm}$ no espécime no8 e a média das medidas desta secção foi de 1,32mm. Quanto a secção do terço apical, a maior distância entre o compartimento pulpar e o fundo do sulco foi de 1,57 no espécime $\mathrm{n}^{0} 1$, a menor de 0,65 no espécime 12 e a espessura média das medidas nesse terço foi de $1,11 \mathrm{~mm}$. 


\section{FIGURA 32}

Figura 32A - Características morfológicas da secção cervical do espécime n7. O contorno do canal principal está destacado pela linha verde. É possível observar o formato arredondado do canal, com discreta alteração em sua configuração espacial associada ao sulco palatogengival. A linha amarela revela a espessura de dentina existente entre o fundo do sulco e o canal radicular de $1,55 \mathrm{~mm}$ antes do preparo

Figura 32B - A mesma secção observada depois do preparo biomecânico. O novo contorno dado ao canal radicular é mais arredondado e uniforme, conforme a demarcação feita pela linha azul, a linha verde sobreposta demonstra a antiga forma do conduto. A menor distância entre o fundo do sulco e o interior do canal mudou com a instrumentação, conforme destacado pela linha vermelha, passando a 1,5mm. A pequena saliência na parede pulpar associada ao sulco palatogengival foi eliminada e a espessura dentinária no canal diminuída

Figura 32C - A secção do terço médio revela a existência de dois canais localizados na parte central das duas raízes, existe ainda um espaço com formado arredondado correspondente ao espaço interradicular. A distância entre o canal da raiz principal e o fundo do sulco é de 1,41 mm e do espaço interradicular e o canal da raiz principal de $1,14 \mathrm{~mm}$ antes da instrumentação

Figura 32D - Mesma secção observada após o preparo biomecânico. A linha azul demonstra o alargamento causado pelo preparo com desgaste preferencial da parede palatina do canal da raiz principal. As distâncias representadas pelas linhas vermelhas são de $1,17 \mathrm{~mm}$ de espessura de dentina entre o fundo do sulco e o canal e de $0,46 \mathrm{~mm}$ entre o espaço interradicular e o canal, indicando redução de espessura

Figura 32E - O terço apical apresentou a morfologia dos condutos semelhante ao terço médio. A distância entre o canal da raiz principal e o fundo do sulco é de $1,96 \mathrm{~mm}$ e do espaço interradicular e o canal da raiz principal de $1,22 \mathrm{~mm}$ antes da instrumentação.

Figura 32F: Terço apical após o preparo biomecânico. A linha azul demonstra o desgaste preferencial da parede palatina do canal da raiz principal, semelhante ao observado no terço médio. As linhas vermelhas indicam redução da espessura da dentina, $1,13 \mathrm{~mm}$ de espessura de dentina entre o fundo do sulco e o canal; $0,58 \mathrm{~mm}$ entre o espaço interradicular e o canal da raiz principal

Figura 32G - Características da anatomia do espécime n07. O canal da raiz acessória inicia-se na região limítrofe entre o terço médio e o terço apical da raiz. O segundo canal não foi localizado, a radiografia do limite apical demonstra a dificuldade de observar o segundo canal 

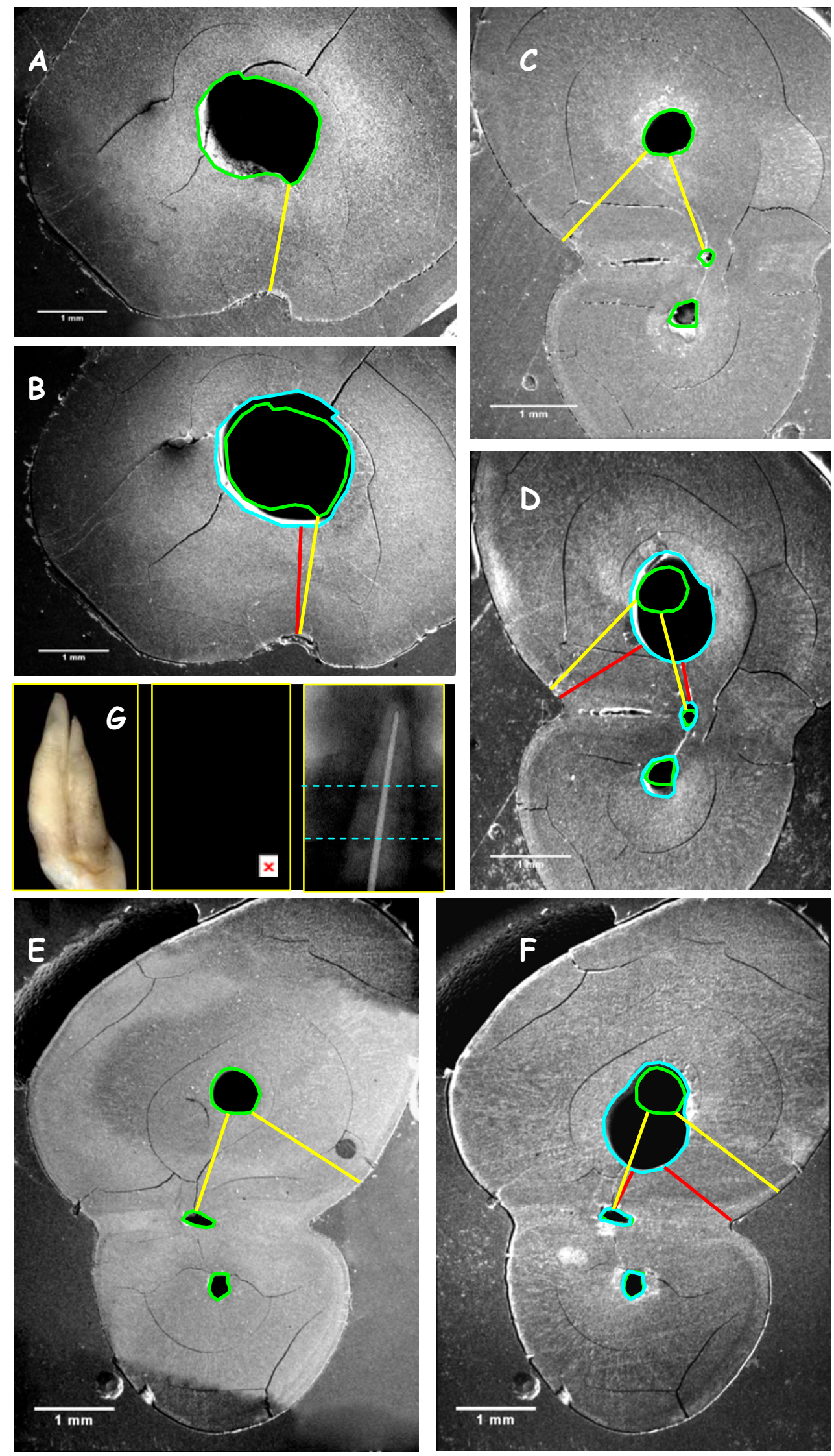


\section{FIGURA 33}

Figura 33A - Aspectos da morfologia da superfície radicular do espécime n08 à microscopia eletrônica de varredura. Nota-se acentuado degrau na junção amelocementária causado pelo sulco palatogengival. Nos terços cervical e médio da raiz, observam-se acúmulos de cálculo dentário. O terço apical apresenta a superfície radicular bastante irregular devido à reabsorção e deposição desordenada de cemento

Figura 33B - A secção cervical do dente revela um canal com contorno irregular de aspecto elíptico destacado pela linha verde. A menor distância entre o fundo do sulco e o canal radicular é de $1,27 \mathrm{~mm}$ antes do preparo biomecânico (linha amarela)

Figura 33C - Após a instrumentação observou-se o arredondamento da secção do conduto, com maior remoção da camada interna de dentina das paredes vestibular e palatina do canal conforme destacado pela linha azul. A linha vermelha indica que a espessura de dentina entre o fundo do sulco e o canal diminuiu para $1,1 \mathrm{~mm}$

Figura 33D - O terço médio apresentou o canal com morfologia semelhante à do terço cervical. A distância entre o leito do sulco e o canal radicular era de $1 \mathrm{~mm}$ antes da instrumentação (linha amarela)

Figura 33E - O desgaste da dentina causado pela instrumentação também foi semelhante ao observado no teço cervical (linha azul). A linha vermelha indica que a espessura de dentina entre o fundo do sulco e o canal diminuiu para $0,73 \mathrm{~mm}$

Figura 33F - Características da morfologia do canal radicular na secção apical. O canal neste terço oval como observado pela linha verde. A distância entre o fundo do sulco e o canal é de $1,07 \mathrm{~mm}$ antes da instrumentação

Figura 33G - Na secção do terço apical observou-se que preparo biomecânico pouco diminuiu a distância entre o fundo do sulco e o canal radicular, que foi de $1,05 \mathrm{~mm}$. Apesar de o preparo promover o arredondamento da secção do canal, as paredes, vestibular e mesial sofreram maior desgaste neste espécime

Figuras 33H - Três perspectivas do espécime n8: macroscópica, radiográfica antes da instrumentação e radiográfica após a instrumentação 

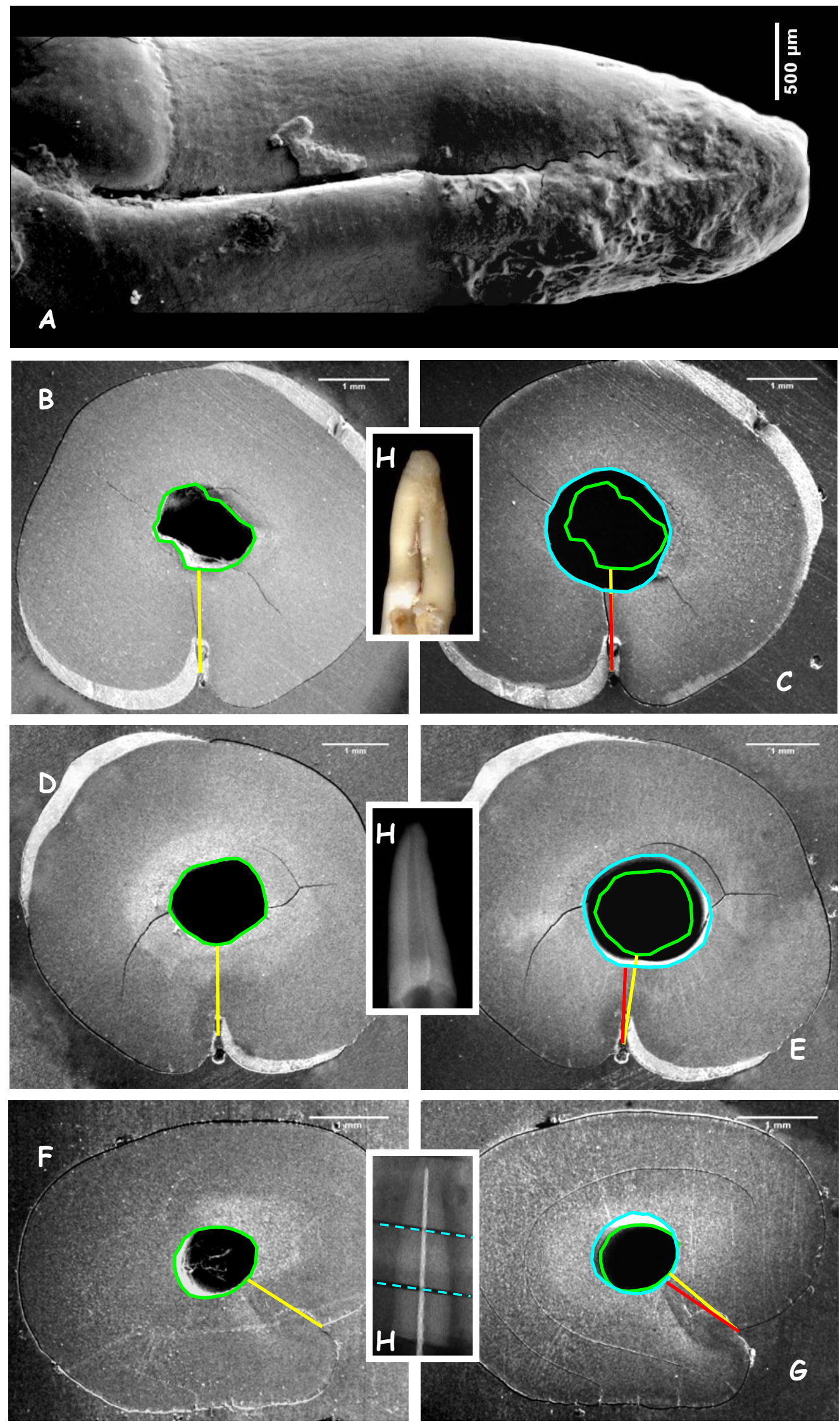


\section{FIGURA 34}

Figura 34A - A secção cervical do espécime 19 revelou o canal com forma arredondada conforme destacado pela linha verde, e distância entre o fundo do sulco e o interior do canal é de 1,24mm (linha amarela)

Figura 34B - Mesma secção observada após o preparo biomecânico. Nota-se o alargamento uniforme do conduto que tornou-se mais circular. A linha vermelha indica a diminuição da distância entre o fundo do sulco e o interior do canal medindo $1,15 \mathrm{~mm}$

Figura 34C - No terço médio foi identificado a presença de um nódulo pulpar aderido à parede disto lingual do canal, na mesma direção do sulco palatogengival. O contorno do canal é alterado neste ponto nodular, conforme destacado pela linha verde. A menor distância entre o fundo do sulco e o interior do canal é de 1,14mm (linha amarela)

Figura 34D - Mesma secção observada depois da instrumentação. A linha azul demonstra o contorno circular do canal proporcionado pelo alargamento do conduto, além da remoção ou desgaste do nódulo pulpar. A distância entre o canal e o fundo do sulco caiu para 1,08mm (linha vermelha)

Figura 34E - Magnificação da região destacada pelo quadro branco destacando o nódulo pulpar

Figura 34G - A secção apical do espécime apresentava o conduto com forma elíptica antes da instrumentação (linha verde). A menor distância entre o fundo do sulco e o canal radicular é de $1 \mathrm{~mm}$

Figura 34H - Depois do preparo biomecânico o contorno do conduto tornou-se quase circular, com desgaste preferencial das paredes mesial e distal. A linha vermelha demonstra a diminuição da distância entre o sulco e o canal que caiu para $0,9 \mathrm{~mm}$ 




\subsubsection{Análise comparativa do desgaste produzido pelo preparo biomecânico em diferentes paredes do conduto radicular}

Toda secção de cada espécime avaliado teve quatro medidas de distância entre o interior do canal e a interface resina-dente aferidas. A primeira medida foi a menor distância entre o leito do sulco palatogengival e o interior do canal, sendo considerada esta medida como referência para as outras três medidas. As medidas auxiliares foram feitas em pontos localizados em porções afastadas da região do sulco palatogengival. Assim, a espessura da dentina foi medida relacionando com as faces: vestibular, mesial, distal ou palatina livres do sulco palatogengival, pois o sulco nem sempre estava localizado na face palatina dos espécimes. Também, as medidas auxiliares foram estabelecidas buscando a maior eqüidistância possível entre as medidas prévias.

A análise de variância entre as medidas de espessura de dentina foi realizada através do teste estatístico ANOVA para " $n$ " grupos pareados e revelou que a distância do sulco ao canal radicular é menor que as medidas auxiliares antes e depois do preparo biomecânico $p<0,05$. Realizou-se ainda comparações individuais entre as espessuras de dentina nos terços: cervical, médio e apical, aplicando o teste de Tukey. Observou-se que a espessura de dentina na medida entre o sulco e o canal é menor que pelo menos duas das três medidas auxiliares antes e depois do preparo biomecânico $(p<0,05)$ nos terços cervical, médio e apical.

Após medidas as distâncias antes e depois do preparo biomecânico, subtraíram-se a segunda medida da primeira computando a distância equivalente à quantidade de dentina desgastada pela instrumentação. Esses dados foram comparados para descobrir se houve desgaste preferencial de uma parede, principalmente para buscar a compreensão se a presença do sulco palatogengival influencia no desgaste preferencial de uma ou outra parede, no preparo biomecânico de canais de dentes portadores. Ao mesmo tempo para verificar se as paredes dentárias associadas ao sulco palatogengival se reduziam mais ainda em relação às demais. 
A análise de variância entre as medidas de desgaste foi realizada aplicando-se o teste estatístico ANOVA para "n" grupos pareados e não revelou diferenças significantes estatisticamente entre os desgastes das paredes do conduto com valores de $p>0,05$. Realizou-se ainda comparações individuais entre os desgastes nos terços: cervical, médio e apical, aplicando o teste de Tukey e novamente não foram encontradas diferenças significantes estatisticamente $(p>0,05)$.

Como cada espécime possuía três secções as comparações foram feitas entre os grupos de secção. Para verificação da consistência dos dados obtidos pelas medidas, aplicou-se o índice kappa intra-examinador, para avaliar a concordância entre as medidas, os resultados foram considerados substanciais $>0,6$ em todas as medidas das secções.

A média dos desgastes entre o canal radicular e o sulco palatogengival na interface dente-resina antes e depois do preparo biomecânico foram: $0,11 \mathrm{~mm}$ no terço cervical; $0,2 \mathrm{~mm}$ no teço médio; $0,15 \mathrm{~mm}$ no terço apical.

A média das medidas de desgaste auxiliares nas secções cervicais foram: 0,15mm na medida auxiliar $1 ; 0,11 \mathrm{~mm}$ na medida auxiliar 2; 0,13mm na medida auxiliar 3. A média das espessuras de dentina nos pontos auxiliares antes da instrumentação eram: 1,6mm, 1,95mm e 2,06mm; e depois da instrumentação eram:1,45mm, 1,85mm, 1,83mm respectivamente.

A média das medidas de desgaste auxiliares nas secções medias foram: $0,16 \mathrm{~mm}$ na medida auxiliar $1 ; 0,15 \mathrm{~mm}$ na medida auxiliar $2 ; 0,16 \mathrm{~mm}$ na medida auxiliar 3. A média das espessuras de dentina nos pontos auxiliares antes da instrumentação eram: 1,61mm, 1,92mm e 2,16mm; e depois da instrumentação eram:1,45mm, 1,78mm, $2 \mathrm{~mm}$ respectivamente.

A média das medidas de desgaste auxiliares nas secções apicais foram: $0,17 \mathrm{~mm}$ na medida auxiliar $1 ; 0,16 \mathrm{~mm}$ na medida auxiliar $2 ; 0,11 \mathrm{~mm}$ na medida auxiliar 3. A média das espessuras de dentina nos pontos auxiliares antes da instrumentação eram: 1,36mm, 1,55mm e 1,58mm; e depois da instrumentação eram:1,18mm, 1,39mm, 1,47mm respectivamente. 
As das distâncias entre o interior do canal e a interface resina-dente antes e depois do preparo biomecânico, bem como a medida da distância de desgaste produzida pela instrumentação estão dispostas nas tabelas a seguir:

Tabela 11 - Medidas em milímetros das distâncias entre o canal radicular e o sulco palatogengival na interface dente-resina antes e depois do preparo biomecânico, além do desgaste causado pela instrumentação nos terços cervical (1), médio (2) e apical (3) em cada espécime analisado. As médias encontram-se na linha de tons de cinza. DSCA - distância sulco ao canal antes, DSCD distância sulco ao canal depois e DES - desgaste, 1,2 e 3- secção

\begin{tabular}{ccccccccc} 
DSCA1 & DSCD1 & DES1 & DSCA2 & DSCD2 & DES2 & DSCA3 & DSCD3 & DES3 \\
\hline 2,28 & 1,98 & 0,3 & 2,23 & 1,32 & 0,91 & 1,59 & 1,57 & 0,02 \\
1,27 & 0,99 & 0,28 & 1,69 & 0,98 & 0,71 & 1,54 & 1,25 & 0,29 \\
2,1 & 1,87 & 0,23 & 1,99 & 1,82 & 0,17 & 1 & 0,99 & 0,01 \\
1,11 & 1,01 & 0,1 & 1,1 & 1 & 0,1 & 1,14 & 1,1 & 0,04 \\
\hline 1,5 & 1,5 & 0 & 1,54 & 1,43 & 0,11 & 1,25 & 1,25 & 0 \\
1,65 & 1,65 & 0 & 1,59 & 1,53 & 0,06 & 1,24 & 1,11 & 0,13 \\
1,55 & 1,5 & 0,05 & 1,48 & 1,17 & 0,31 & 1,96 & 1,13 & 0,83 \\
1,27 & 1,1 & 0,17 & 1 & 0,73 & 0,27 & 1,07 & 1,05 & 0,02 \\
\hline 1,35 & 1,22 & 0,13 & 1,31 & 1,11 & 0,2 & 1,28 & 1,13 & 0,15 \\
2 & 2 & 0 & 2 & 1,53 & 0,47 & 1,47 & 1,16 & 0,31 \\
\hline 1,76 & 1,62 & 0,14 & 1,59 & 1,59 & 0 & 1,39 & 1,36 & 0,03 \\
\hline 1,44 & 1,44 & 0 & 1,36 & 1,33 & 0,03 & 0,84 & 0,65 & 0,19 \\
\hline 1,28 & 1,25 & 0,03 & 1,28 & 1,22 & 0,06 & 1,07 & 0,88 & 0,19 \\
\hline 1,91 & 1,86 & 0,05 & 1,8 & 1,64 & 0,16 & 1,57 & 1,46 & 0,11 \\
\hline 2,2 & 1,83 & 0,37 & 1,65 & 1,46 & 0,19 & 1,01 & 0,88 & 0,13 \\
\hline 1,87 & 1,7 & 0,17 & 1,76 & 1,75 & 0,01 & 1,45 & 1,45 & 0 \\
\hline 1,46 & 1,42 & 0,04 & 1,42 & 1,42 & 0 & 0,94 & 0,79 & 0,15 \\
1,33 & 1,33 & 0 & 1,29 & 1,25 & 0,04 & 1,13 & 0,89 & 0,24 \\
1,24 & 1,15 & 0,09 & 1,14 & 1,08 & 0,06 & 1 & 0,9 & 0,1 \\
1,21 & 1,06 & 0,15 & 1,2 & 1,01 & 0,19 & 1,21 & 1,11 & 0,1 \\
\hline 1,59 & 1,47 & 0,12 & 1,52 & 1,32 & 0,20 & 1,26 & 1,11 & 0,15 \\
\hline & & & & & & & & \\
\hline
\end{tabular}


Tabela 12 - Medidas em milímetros das distâncias auxiliares 1-3 entre o canal radicular e a interface dente-resina antes e depois do preparo biomecânico, além do desgaste causado pela instrumentação do terço cervical de cada espécime analisado. As médias encontram-se na linha de tons de cinza. $A n^{\circ} A n^{\circ}$ - Auxiliar x número da medida x Antes x número da secção; $A n^{\circ} D n^{\circ}$ - Auxiliar x número da medida x Depois x número da secção; DESnºAn desgaste $\mathrm{x}$ número da secção $\mathrm{x}$ Auxiliar $\mathrm{x}$ número da medida

\begin{tabular}{ccccc|cccc} 
A1A1 & A1D1 & DES1A1 & A2A1 & A2D1 & DES1A2 & A3A1 & A3D1 & DES1A3 \\
1,85 & 1,31 & 0,54 & 1,94 & 1,35 & 0,59 & 2,56 & 2,03 & 0,53 \\
1,2 & 1,15 & 0,05 & 1,13 & 1,05 & 0,08 & 1,54 & 1,52 & 0,02 \\
2,11 & 1,54 & 0,57 & 1,99 & 1,71 & 0,28 & 2,7 & 2,2 & 0,5 \\
1,51 & 1,42 & 0,09 & 1,94 & 1,73 & 0,21 & 2,27 & 2,03 & 0,24 \\
1,38 & 1,37 & 0,01 & 1,55 & 1,54 & 0,01 & 1,66 & 1,63 & 0,03 \\
1,32 & 1,27 & 0,05 & 1,97 & 1,96 & 0,01 & 2,03 & 2 & 0,03 \\
1,97 & 1,9 & 0,07 & 2,1 & 1,99 & 0,11 & 2,07 & 2,05 & 0,02 \\
1,8 & 1,75 & 0,05 & 1,58 & 1,37 & 0,21 & 1,88 & 1,87 & 0,01 \\
1,43 & 1,39 & 0,04 & 1,65 & 1,63 & 0,02 & 1,99 & 1,97 & 0,02 \\
1,72 & 1,71 & 0,01 & 2,02 & 2 & 0,02 & 1,95 & 1,9 & 0,05 \\
1,29 & 1,22 & 0,07 & 1,96 & 1,92 & 0,04 & 2,01 & 1,88 & 0,13 \\
1,2 & 1,13 & 0,07 & 1,85 & 1,81 & 0,04 & 1,99 & 1,98 & 0,01 \\
1,46 & 1,41 & 0,05 & 2,3 & 2,28 & 0,02 & 1,77 & 1,76 & 0,01 \\
1,81 & 1,39 & 0,42 & 1,87 & 1,85 & 0,02 & 1,99 & 1,89 & 0,1 \\
2,26 & 1,8 & 0,46 & 2,3 & 2,08 & 0,22 & 2,03 & 1,58 & 0,45 \\
1,7 & 1,44 & 0,26 & 2,56 & 2,44 & 0,12 & 2,28 & 2,19 & 0,09 \\
1,95 & 1,89 & 0,06 & 2,05 & 1,98 & 0,07 & 2,22 & 2,13 & 0,09 \\
1,4 & 1,38 & 0,02 & 1,88 & 1,86 & 0,02 & 1,87 & 1,85 & 0,02 \\
1,33 & 1,32 & 0,01 & 2,64 & 2,61 & 0,03 & 2,26 & 2,22 & 0,04 \\
1,31 & 1,21 & 0,1 & 1,78 & 1,77 & 0,01 & 2,14 & 2 & 0,14 \\
1,60 & 1,45 & 0,15 & 1,95 & 1,85 & 0,11 & 2,06 & 1,93 & 0,13 \\
& & & & & & & &
\end{tabular}


Tabela 13 - Medidas em milímetros das distâncias auxiliares 1-3 entre o canal radicular e a interface dente-resina antes e depois do preparo biomecânico, além do desgaste causado pela instrumentação do terço médio de cada espécime analisado. As médias encontram-se na linha de tons de cinza. $A n^{\circ} \mathrm{An}^{\circ}$ - Auxiliar $\mathrm{x}$ número da medida $\mathrm{x}$ Antes $\mathrm{x}$ número da secção; $A n^{\circ} \mathrm{Dn}^{\circ}$ - Auxiliar $\mathrm{x}$ número da medida $\mathrm{x}$ Depois $\mathrm{x}$ número da secção; $\mathrm{DESn}{ }^{\circ} \mathrm{An}{ }^{\circ}$ - desgaste $\mathrm{x}$ número da secção $\mathrm{x}$ Auxiliar $\mathrm{x}$ número da medida

\begin{tabular}{ccccccccc} 
A1A2 & A1D2 & DES2A1 & A2A2 & A2D2 & DES2A2 & A3A2 & A3D2 & DES2A3 \\
1,9 & 1,61 & 0,29 & 1,93 & 1,72 & 0,21 & 3,04 & 2,77 & 0,27 \\
1,73 & 1,03 & 0,7 & 1,63 & 1,25 & 0,38 & 2,16 & 1,53 & 0,63 \\
1,84 & 1,65 & 0,19 & 1,89 & 1,66 & 0,23 & 2,59 & 2,34 & 0,25 \\
1,76 & 1,57 & 0,19 & 2,08 & 2,05 & 0,03 & 2,17 & 2,07 & 0,1 \\
1,67 & 1,65 & 0,02 & 1,45 & 1,43 & 0,02 & 1,77 & 1,7 & 0,07 \\
1,21 & 1,19 & 0,02 & 1,6 & 1,59 & 0,01 & 1,76 & 1,76 & 0 \\
1,21 & 0,51 & 0,7 & 2,13 & 1,94 & 0,19 & 1,91 & 1,27 & 0,64 \\
1,62 & 1,54 & 0,08 & 1,8 & 1,39 & 0,41 & 2 & 2 & 0 \\
1,51 & 1,4 & 0,11 & 1,49 & 1,48 & 0,01 & 1,49 & 1,45 & 0,04 \\
1,82 & 1,79 & 0,03 & 2,12 & 2,03 & 0,09 & 2,02 & 1,85 & 0,17 \\
1,56 & 1,55 & 0,01 & 1,92 & 1,81 & 0,11 & 2 & 1,97 & 0,03 \\
1,12 & 1,11 & 0,01 & 1,61 & 1,6 & 0,01 & 2,01 & 1,98 & 0,03 \\
1,45 & 1,35 & 0,1 & 2,65 & 2,49 & 0,16 & 2,48 & 2,43 & 0,05 \\
1,86 & 1,77 & 0,09 & 1,91 & 1,77 & 0,14 & 2,58 & 2,24 & 0,34 \\
1,88 & 1,83 & 0,05 & 2,31 & 2,23 & 0,08 & 2,02 & 1,97 & 0,05 \\
1,61 & 1,36 & 0,25 & 2,41 & 2,37 & 0,04 & 2,3 & 2,23 & 0,07 \\
1,87 & 1,81 & 0,06 & 2,35 & 2,32 & 0,03 & 2,19 & 2,16 & 0,03 \\
1,69 & 1,59 & 0,1 & 1,9 & 1,83 & 0,07 & 1,8 & 1,78 & 0,02 \\
1,29 & 1,27 & 0,02 & 2,02 & 1,61 & 0,41 & 2,49 & 2,45 & 0,04 \\
1,53 & 1,38 & 0,15 & 1,25 & 0,95 & 0,3 & 2,45 & 2 & 0,45 \\
\hline 1,61 & 1,45 & 0,16 & 1,92 & 1,78 & 0,15 & 2,16 & 2,00 & 0,16 \\
\hline
\end{tabular}


Tabela 14 - Medidas em milímetros das distâncias auxiliares 1-3 entre o canal radicular e a interface dente-resina antes e depois do preparo biomecânico, além do desgaste causado pela instrumentação do terço apical de cada espécime analisado. $A n^{\circ} \mathrm{An}^{\circ}$ - Auxiliar x número da medida $x$ Antes $x$ número da secção; $A n^{\circ} D^{\circ}{ }^{\circ}$ - Auxiliar $x$ número da medida $x$ Depois $x$ número da secção; $D E S n^{\circ} A n^{\circ}$ - desgaste $x$ número da secção $x$ Auxiliar $x$ número da medida

\begin{tabular}{|c|c|c|c|c|c|c|c|c|}
\hline A1A3 & A1D3 & DES3A1 & $\mathrm{A} 2 \mathrm{~A} 3$ & A2D3 & DES3A2 & A3АЗ & A3D3 & DES3A3 \\
\hline 1,54 & 1,44 & 0,1 & 1,2 & 1,19 & 0,01 & 2,21 & 2,19 & 0,02 \\
\hline 1,83 & 1,56 & 0,27 & 1,13 & 0,4 & 0,73 & 1,19 & 0,98 & 0,21 \\
\hline 1,1 & 1,08 & 0,02 & 1,64 & 1,64 & 0 & 1,74 & 1,74 & 0 \\
\hline 1,19 & 1,12 & 0,07 & 1,45 & 1,45 & 0 & 1,2 & 1,2 & 0 \\
\hline 1,12 & 1,11 & 0,01 & 1,51 & 1,49 & 0,02 & 1,41 & 1,36 & 0,05 \\
\hline 1,25 & 1,11 & 0,14 & 1,38 & 1,32 & 0,06 & 0,87 & 0,74 & 0,13 \\
\hline 1,13 & 0,42 & 0,71 & 1,74 & 1,02 & 0,72 & 1,86 & 1,84 & 0,02 \\
\hline 1,26 & 1,18 & 0,08 & 1,27 & 1,26 & 0,01 & 1,89 & 1,88 & 0,01 \\
\hline 1,18 & 0,93 & 0,25 & 1,7 & 1,56 & 0,14 & 1,39 & 1,23 & 0,16 \\
\hline 2,04 & 1,85 & 0,19 & 1,58 & 1,53 & 0,05 & 1,8 & 1,26 & 0,54 \\
\hline 1,26 & 1,24 & 0,02 & 1,23 & 1,2 & 0,03 & 1,76 & 1,75 & 0,01 \\
\hline 1,01 & 0,79 & 0,22 & 1,31 & 1,07 & 0,24 & 1,16 & 1,15 & 0,01 \\
\hline 1,41 & 1,3 & 0,11 & 0,82 & 0,75 & 0,07 & 1,6 & 1,46 & 0,14 \\
\hline 2,57 & 2,19 & 0,38 & 2,39 & 2,24 & 0,15 & 1,74 & 1,43 & 0,31 \\
\hline 1,2 & 1,04 & 0,16 & 1,51 & 1,3 & 0,21 & 1,13 & 0,95 & 0,18 \\
\hline 1,32 & 1,13 & 0,19 & 1,93 & 1,8 & 0,13 & 1,91 & 1,85 & 0,06 \\
\hline 1,37 & 1,31 & 0,06 & 1,08 & 0,91 & 0,17 & 1,36 & 1,29 & 0,07 \\
\hline 1,09 & 0,98 & 0,11 & 1,8 & 1,7 & 0,1 & 1,65 & 1,6 & 0,05 \\
\hline 1,16 & 0,96 & 0,2 & 2,22 & 1,89 & 0,33 & 1,79 & 1,52 & 0,27 \\
\hline 1,15 & 0,93 & 0,22 & 2,17 & 2,08 & 0,09 & 2,02 & 1,98 & 0,04 \\
\hline 1,36 & 1,18 & 0,18 & 1,55 & 1,39 & 0,16 & 1,58 & 1,47 & 0,11 \\
\hline
\end{tabular}


O tamanho das áreas dos canais antes e depois da instrumentação está disposto no quadro abaixo.

\begin{tabular}{|c|c|c|c|c|c|c|c|}
\hline \multirow{3}{*}{ Espécime } & \multirow{3}{*}{ Área-mm2 } & \multicolumn{3}{|c|}{ Antes } & \multicolumn{3}{|c|}{ Depois } \\
\hline & & \multicolumn{6}{|c|}{ Terço } \\
\hline & & Cervical & Médio & Apical & Cervical & Médio & Apical \\
\hline 01 & Área & 0,07 & 0,06 & 0,21 & 1,65 & 0,54 & 0,37 \\
\hline 02 & Área & 0,72 & 1,18 & 0,4 & 1,53 & 1,27 & 0,57 \\
\hline 03 & Área & 2 & 1,84 & 0,48 & 2,1 & 1,85 & 0,6 \\
\hline 04 & Área & 1,78 & 1,39 & 0,65 & 1,8 & 1,8 & 1,01 \\
\hline 05 & Área & 3,15 & 3 & 1,28 & 3,88 & 3,64 & 1,98 \\
\hline 06 & Área & 0,81 & 0,67 & 0,37 & 1,46 & 1,1 & 0,72 \\
\hline 07 & Área & 2,08 & 0,25 & 0,23 & 2,9 & 0,97 & 1,05 \\
\hline 08 & Área & 0,95 & 1,27 & 0,62 & 2,16 & 2,1 & 0,82 \\
\hline 09 & Área & 1,19 & 1,25 & 0,5 & 1,73 & 1,63 & 0,85 \\
\hline 10 & Área & 1,94 & 1,86 & 0,83 & 2,6 & 2,33 & 1,05 \\
\hline 11 & Área & 1,7 & 1,44 & 0,46 & 1,74 & 1,7 & 0,66 \\
\hline 12 & Área & 0,9 & 0,8 & 0,3 & 1,62 & 0,98 & 0,59 \\
\hline 13 & Área & 1,58 & 1,55 & 0,41 & 2,06 & 1,75 & 0,49 \\
\hline 14 & Área & 2,06 & 2,03 & 1,15 & 2,87 & 2,17 & 1,34 \\
\hline 15 & Área & 3,31 & 1,56 & 0,3 & 4,07 & 1,58 & 0,62 \\
\hline 16 & Área & 1,83 & 1,58 & 0,68 & 2,02 & 1,86 & 1,17 \\
\hline 17 & Área & 1,86 & 1,58 & 0,34 & 2,11 & 1,85 & 0,72 \\
\hline 18 & Área & 1,24 & 1,4 & 0,71 & 1,53 & 1,47 & 1,07 \\
\hline 19 & Área & 1,01 & 0,96 & 0,36 & 1,13 & 1,1 & 0,7 \\
\hline 20 & Área & 0,68 & 0,74 & 0,4 & 1,02 & 0,99 & 0,8 \\
\hline & & 1,54 & 1,32 & 0,53 & 2,10 & 1,63 & 0,86 \\
\hline
\end{tabular}

Figura 35 - Comparação das medidas e médias das áreas do canal principal antes e depois do preparo biomecânico 
DISCUSS ÃO 


\section{DISCUSSÃO}

\subsection{Da concepção do trabalho}

Este trabalho suplementa o estudo sobre o sulco palatogengival desenvolvido por LARA ${ }^{79}$ sob orientação do Professor Dr. Alberto Consolaro em 1993. Desde então muito pouco foi acrescentado ao assunto estudado quase que exclusivamente no nível clínico, principalmente através de casos clínicos isolados.

O plano do estudo foi ampliar a abordagem sobre o sulco palatogengival. Os dados epidemiológicos e ao mesmo tempo avaliação das características físicas do sulco palatogengival em pacientes permitiria contribuir no esclarecimento de uma das mais antigas e controversas dúvidas sobre o sulco palatogengival: sua etiopatogenia. As hipóteses sobre o desenvolvimento do sulco são difíceis de se confirmar por estudos experimentais. A teoria de ATIKINSON ${ }^{9}$ (1943) propunha uma deformação do germe dentário, difícil de ser reproduzida laboratorialmente in vitro ou in vivo. Por outro lado para checar a "tentativa" do dente em formar outra raiz ${ }^{82}$, não se têm modelos experimentais para estudar esta hipótese também implica na compreensão plena da odontogênese. A proposta de observar o tipo facial, a relação entre os arcos e a forma dos arcos dentários, além de fatores mais específicos como a história familiar de pacientes portadores e outras associações presentes em pacientes portadores pôde ajudar na discussão coerente fundamentada sobre a etiopatogenia do sulco palatogengival.

A possibilidade de lidar com uma amostra de pacientes portadores do sulco colocaria à prova os métodos de tratamento e diagnóstico relatados e ainda acrescentaria novos conhecimentos relacionados à atuação clínica.

Outro objetivo importante no planejamento deste estudo foi continuar o estudo morfológico do sulco palatogengival. Apenas os trabalhos de KOGON 75 (1986), GAO et al. ${ }^{53}$ (1989) e LARA, CONSOLARO e BRUCE ${ }^{80}$ (2000) 
avaliaram sistematicamente aspectos macroscópicos e microscópicos de dentes portadores do sulco palatogengival em amostras consistentes. Alguns temas ainda continuavam pouco explorados como o tipo de junção amelocementária, a formação de cálculo dentário e as reabsorções radiculares em dentes com sulco palatogengival.

No planejamento deste estudo sempre houve uma preocupação com possíveis cuidados especiais que se deveria tomar no tratamento endodôntico de dentes com sulco palatogengival. Como não há nenhum trabalho direcionado ao assunto, a busca de um método que pudesse ser aplicado no trabalho tornou-se um desafio. Foi quando o Professor Dr. Alberto Consolaro se recordou de uma conversa informal que tivera com o Professor Dr. Roberto Pinheiro Borges. Nesta comunicação, o professor lhe falara sobre uma metodologia desenvolvida para sua tese de mestrado, orientada pelo professor Dr. Clóvis Monteiro Bramante, que proporcionava a avaliação da morfologia dos canais radiculares antes e depois da instrumentação. Relatou ainda, que tal metodologia havia sido publicada no Journal of Endodontics (BRAMANTE et al. $\left.{ }^{25}, 1987\right)$ e se tornado referência para estudos nesta área. Após a avaliação detalhada da tese e do artigo internacional, constatou-se que a metodologia seria ideal para a proposta do trabalho, dando subsídios à compreensão de como seriam as alterações causadas pelo preparo biomecânico em dentes com sulco palatogengival.

\subsection{Da etiopatogenia do sulco palatogengival}

Para consolidar o conhecimento sobre o assunto e explicar os possíveis mecanismos de formação do sulco palatogengival através das informações e dados resgatados de trabalhos anteriores organizamos duas teorias distintas: extrínseca e intrínseca.

Teoria Extrínseca: as causas do sulco palatogengival são externas ao germe dentário e independentes dos fatores genéticos e ou relacionados às interações celulares e teciduais da odontogênese. 
O sulco palatogengival pode ser resultante de um dobramento do epitélio interno do órgão do esmalte e da bainha epitelial de Hertwig ${ }^{58} \mathrm{em}$ uma fase anterior à mineralização dos tecidos dentários. Após a deposição da matriz orgânica e sua mineralização, os tecidos duros ficam marcados por um sulco que se estende do cíngulo para a raiz dentária, atravessando a junção amelocementária. Esta teoria para explicar a formação do sulco palatogengival supõe a ocorrência de forças atuando sobre os incisivos laterais superiores, o dente mais freqüentemente comprometido.

Esta explicação para a etiopatogenia do sulco palatogengival pode ser fundamentada nos estudos específicos de ATKINSON ${ }^{9}$ (1948) sobre a formação do incisivo lateral superior. Durante a odontogênese, o incisivo lateral superior representa o último dente a iniciar sua mineralização e isto ocorre em um espaço delimitado anteriormente pelo incisivo central superior, por palatino e posteriormente pelo canino superior e primeiro pré-molar superior. Os vetores de crescimento craniofacial, os deslocamentos eruptivos e a pressão local dos componentes anatômicos como vasos, nervos e estruturas ósseas de densidades variáveis gerariam forças locais que promoveriam o dobramento do germe do incisivo lateral superior. Este dobramento poderia ser de tal magnitude que eventualmente promoveria a formação de raiz supranumerária quando fosse muito profundo.

A teoria extrínseca pelo dobramento do órgão do esmalte pode explicar também sulcos do desenvolvimento em outras faces dos incisivos e outros dentes $17,30,44,52,83,94$. Nos pré-molares inferiores os sulcos do desenvolvimento exclusivamente radiculares são freqüentes e muito variáveis em sua morfologia, provavelmente porque se desenvolvem em tecido ósseo denso em uma fase de pleno crescimento mandibular e disputa espaço com o nervo alveolar inferior que emerge na região via forame para da origem ao ramo mentoniano. 
Teoria Intrínseca: as causas do sulco palatogengival são internas e inerentes ao germe dentário. Estariam implicados genes, mediadores e outros fatores relacionados às interações celulares e teciduais próprias da odontogênese.

A etiopatogenia do sulco palatogengival desde o início foi comparada à do dente invaginado, antigamente também denominado dens in dente. OEHLERS 99 em 1957, classificando várias formas de dente invaginado demonstra uma representação esquemática que se assemelha a um sulco palatogengival em incisivos superiores, sem considerar a existência da anomalia (figura 36). Talvez isto aconteceu porque também atribui-se como causa do dente invaginado um provável dobramento do germe dentário por forças externas ou por encontrar um obstáculo conjuntivo ou ósseo durante a trajetória eruptiva, como demonstrou BRABANT et al. em $1958^{23}$.

Ainda em 1958 OEHLERS ${ }^{100}$ em seu trabalho sobre as "variantes radiculares de dente invaginado" atribuiu a anomalia a alterações na bainha de Hertwig, sem especificá-las. Em seu trabalho destaca a ocorrência da anomalia em pessoas orientais e nos incisivos laterais superiores. Na realidade o trabalho analisava o ainda não identificado sulco palatogengival. Em suas considerações o autor descreve a "invaginação radicular" como uma formação derivada do dobramento para dentro do órgão do esmalte como uma forma invertida de pérola do esmalte (figura 36 ).

Ainda em 1931, SHAW ${ }^{126}$ ao analisar este sulco ainda sem um nome específico nos incisivos de Bantus sul-africanos, para explicar os casos mais exuberantes propunha uma provável tendência do dente dar origem a uma raiz supranumerária. Em 1968, LEE, LEE e POON ${ }^{82}$ reafirmariam esta possibilidade. Isto significa considerar que desde o início do processo haveria uma tentativa para a formação de uma raiz supranumerária, mesmo para os casos mais simples de sulco palatogengival. É comum nos relatos da literatura os casos de sulco palatogengival os associados a presença de uma raiz apendiciforme, verdadeiramente acessória. Um aspecto contraditório nesta 
teoria é a freqüência muito baixa de raízes supranumerárias nos incisivos superiores. A origem das raízes supranumerárias é desconhecida.

$\mathrm{Na}$ literatura, ainda não se tem estudos envolvendo genes e interações moleculares que poderiam estar associados à patogênese do sulco palatogengival. Novas investigações poderiam estabelecer o grau de associação do sulco palatogengival com outras anomalias como anodontia parcial e síndromes com micrognatia e dentes supranumerários. 


\section{FIGURA 36}

Figura 36 A - Esquema indicando a região do germe dentário que sofre dobramento na porção coronária dos incisivos superiores. Tal processo pode ser comum ao dente invaginado e ao sulco palatogengival (modificado de OEHLERS ${ }^{99}$ )

Figura 36 B - Esquema onde o autor classifica como a invaginação do esmalte do tipo 1 , que seria causado pela rotação das partes laterais do órgão do esmalte podendo resultar na fusão dos tecidos dando origem ao dente invaginado (modificado de OEHLERS ${ }^{99}$ )

Figura 36 C - Esquema sobre as "variantes radiculares de dente invaginado". Nesta figura nota-se a evaginação do órgão do esmalte durante a odontogênese que irá dar origem à uma pérola de esmalte (OEHLERS ${ }^{100}$ )

Figura 36 D - O autor elaborou uma hipótese de uma invaginação em forma de botão do órgão do esmalte como uma forma invertida de pérola do esmalte, chamando-a de "invaginação radicular"

Figura 36 E - A maturação das estruturas apontadas na figura $36 \mathrm{C}$ demonstrando a formação de uma pérola de esmalte

Figura 36 F - O autor demonstra nesta figura como ocorre o dobramento para dentro do órgão do esmalte, relacionando como uma forma invertida de pérola do esmalte. Esse raciocínio foi utilizado para explicar a formação do sulco palatogengival 

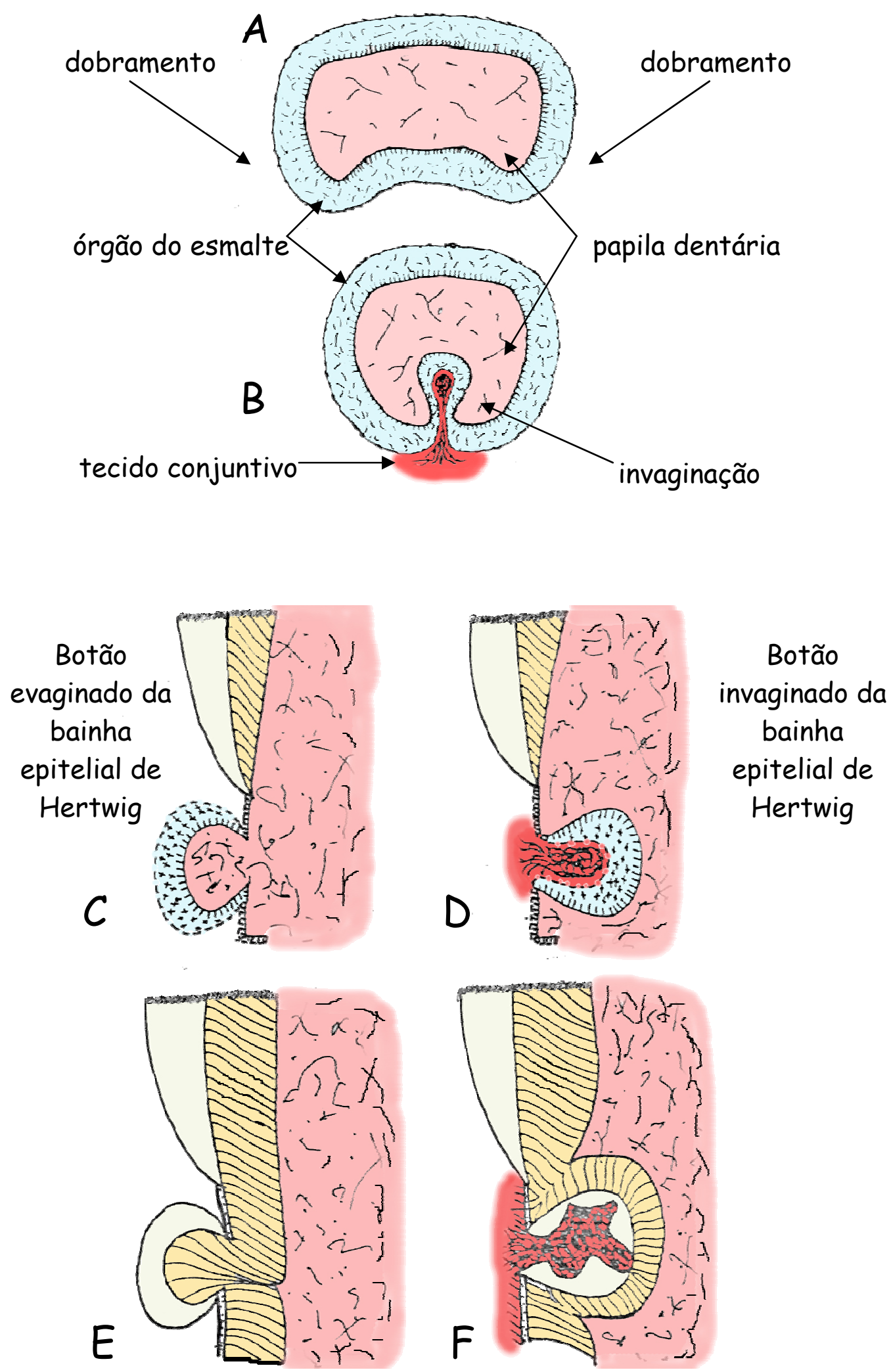

pérola de esmalte invaginação radicular 


\subsection{Dos resultados}

\subsubsection{Da parte A}

A prevalência de $19,8 \%$ do sulco palatogengival em 500 pacientes atendidos seqüencialmente em clínicas odontológicas é muito mais alta quando comparada à de outros poucos trabalhos anteriores. Esta diferença pode ser compreendida se analisarmos a metodologia utilizada nestes trabalhos.

Tabela 15 - Comparação dos achados epidemiológicos de freqüência do sulco palatogengival com o presente trabalho

\begin{tabular}{|c|c|c|c|}
\hline Casuísticas & $\begin{array}{c}\text { número de } \\
\text { pacientes }\end{array}$ & $\begin{array}{c}\text { número de } \\
\text { dentes }\end{array}$ & Prevalência \\
\hline BAČIĆ, M. et al. ${ }^{13}$ & 1081 & - & $1,01 \%$ \\
\hline EVERETT; KRAMER ${ }^{48}$ & - & 625 & $2,88 \%$ \\
\hline HOU; TSAI ${ }^{67}$ & 101 & - & $44,6 \%$ \\
\hline $\mathrm{KOGON}^{75}$ & - & 3168 & $4,6 \%$ \\
\hline PÉCORA; CRUZ FILHO 104 & - & 921 & $2-2,6 \%$ \\
\hline PÉCORA et al. ${ }^{105}$ & 642 & - & $3,9 \%$ \\
\hline PINHEIRO & 500 & - & $19,8 \%$ \\
\hline WITHERS et al. ${ }^{146}$ & 531 & - & $8,5 \%$ \\
\hline
\end{tabular}

Ao utilizem amostras de dentes extraídos para investigar índices de freqüência do sulco palatogengival, como fizeram EVERETT; KAMER ${ }^{48}$ (1972), KOGON ${ }^{75}$ (1986) e PÉCORA et al. ${ }^{105}$ (1991) há uma subjetividade acentuada pela falta de informação sobre a origem, o processo de obtenção e seleção da amostra, além da ausência de dados sobre as pessoas doadoras. Neste tipo de amostra pode-se considerar que os dentes, mesmo quando hígidos ou quase hígidos, tiveram sua extração indicada em função de um insucesso clínico. Provavelmente os dentes com sulco palatogengival reportados são os que 
evoluíram para a doença periodontal inflamatória e/ou por necrose pulpar. No presente trabalho dos 99 pacientes com sulco palatogengival, apenas 39 apresentaram alterações clínicas, periodontais, cariosas ou endodônticas, representando $7,8 \%$ de prevalência de doenças relacionadas ao sulco, mas nenhum dente teve sua extração indicada.

Quando considerados apenas os $7,8 \%$ de pacientes que apresentavam alterações patológicas relacionadas ao sulco palatogengival, encontra-se uma prevalência semelhante à reportada por WITHERS et al. ${ }^{146}$ de $8,5 \%$. Sua amostra era homogênea em relação à idade; os pacientes avaliados eram recrutas, 347 homens e 184 mulheres. Em nosso trabalho, foi estabelecida uma amostra de pacientes em serviços de assistência odontológica com grande variabilidade de idade (6-68 anos) e número maior de pacientes do gênero feminino (322) do que masculino (178). Em ambos os trabalhos não houve relação significante entre gênero e sulco palatogengival.

No trabalho de BAĈIĆ et al. ${ }^{13}$ avaliou-se uma amostra maior com 1081 pacientes, todos homens com idade entre 20-22 anos. Encontraram uma menor prevalência descrita para sulco palatogengival (1,01\%). Na análise dos seus resultados; foram 15 dentes diagnosticados como portadores do sulco e apresentaram profundidade de sondagem $>3 \mathrm{~mm}$. Provavelmente os autores consideraram apenas os casos de sulco palatogengival com perda de inserção do ligamento ou com doença periodontal localizada.

A diferença da prevalência de 19,8\% com a relatada por PÉCORA; CRUZ FILHO ${ }^{104}$ em 1992 pode estar associada a critérios e condições diferentes de diagnóstico, calibração e experiência dos examinadores. Em sua discussão descrevem que em seu trabalho anterior de 1991, consideraram alta a freqüência do sulco palatogengival em incisivos extraídos e que esta baixa prevalência encontrada clinicamente pode estar associada às dificuldades de diagnóstico quando comparadas ao exame de dentes extraídos.

A avaliação de uma amostra constituída apenas por um grupo racial por HOU; TSAI ${ }^{67}$ demonstraram a maior freqüência do sulco palatogengival com $44,6 \%$ de prevalência. Os critérios de diagnóstico empregados foram 
semelhantes aos aplicados no presente trabalho. A influência racial sobre a morfologia dentária é comprovada em vários aspectos como, por exemplo, a maior prevalência da raiz disto lingual dos primeiros molares inferiores, típico de populações orientais, entre os quais os chineses ${ }^{115}$. A maior prevalência do sulco palatogengival neste grupo populacional requer mais estudos confirmativos. Devido à grande miscigenação típica da população brasileira optou-se pela caracterização dos pacientes pela cor da pele ao invés de grupos raciais, não sendo detectada diferença significante entre os três tipos de pele quanto à presença do sulco palatogengival.

Os resultados apresentados no presente estudo quanto à distinção da ocorrência do sulco palatogengival entre os incisivos centrais e laterais superiores, revelaram a maior prevalência de incisivos laterais $(80,4 \%)$ em relação aos incisivos centrais (19,6\%) entre os dentes afetados. Esses dados são compatíveis aos encontrados por $\mathrm{HOU}$; $\mathrm{TSAl}^{67}$ : 83,6\% de incisivos laterais e $16,4 \%$ dos incisivos centrais entre os dentes diagnosticados com sulco palatogengival. WITHERS et al. ${ }^{146}$ apresentaram valores pouco diferentes em relação a esta comparação: relatam a prevalência de 93,8\% nos incisivos laterais superiores e $6,2 \%$ de incisivos centrais superiores entre os portadores do sulco palatogengival.

Vinte e nove pacientes avaliados no estudo apresentaram o sulco palatogengival localizado bilateralmente em seus incisivos laterais superiores, prevalência de $5,8 \%$ entre os 500 pacientes da amostra. Houve ainda 5 pacientes que apresentaram ambos os incisivos centrais acometidos pelo defeito $(1 \%)$ e outros 5 pacientes que possuíam todos os incisivos superiores com o sulco. Achados semelhantes foram relatados por HOU; TSAI ${ }^{67}$, que encontraram $4 \%$ de prevalência para simetria bilateral em incisivos laterais $\mathrm{e}$ centrais; WITHERS et al. ${ }^{146}$, notaram a presença bilateral do sulco em 4 das 531 pessoas $(0,75 \%$ de prevalência) avaliadas em seu estudo.

A possibilidade da atuação de forças capazes de deformar o germe dentário causando o sulco palatogengival estimulou a busca por indícios sobre esta hipótese de etiopatogenia. Essa busca traduziu-se na avaliação de algumas características físicas como o tipo facial, a relação entre os arcos e a 
forma dos arcos dentários nos pacientes portadores. As características relatadas não se revelaram significantes no teste de correlação qui-quadrado. Os portadores do sulco palatogengival distribuem-se proporcionalmente em cada classe das características avaliadas, da mesma forma que os pacientes não possuidores do sulco, aqui utilizados como controle.

A possibilidade de que tais características nunca estivessem realmente relacionadas com a origem do sulco palatogengival deve ser cogitada. Afinal, a odontogênese dos incisivos superiores pode ser considerada como anterior ao completo estabelecimento de tais características físicas. Por outro lado, o crescimento facial, segundo ATKINSON ${ }^{10}$ e posteriormente por ENLOW ${ }^{44}$, é constituído por múltiplos processos de desenvolvimento, em todas as várias regiões crâniofaciais, possibilitando a ocorrência de desequilíbrios durante os processos, mudando a forma e o contorno da face. Sendo assim, não se pode precisar, como cada característica facial avaliada, se apresentava na época da odontogênese dos incisivos superiores.

A avaliação não pôde elucidar a real influência dos fatores físicos, estáticos e temporais, na gama das possíveis causas que poderiam influenciar na formação do sulco palatogengival. A complexa dinâmica da distribuição de forças da face e do crânio, ainda pode ser, portanto, um fator determinante para a formação do sulco palatogengival. Estudos longitudinais que acompanhem o crescimento facial de uma amostra de crianças pelas fases de dentição decídua, mista e permanente, poderão cooperar para o completo entendimento do assunto.

A variável histórico familiar não pôde ser acessada, tão menos considerada com segurança no estudo. Como a quase totalidade dos pacientes avaliados não tinha a menor idéia da existência da alteração, não podiam informar se possuía algum ente próximo com o sulco palatogengival. Isso fez com que a variável fosse praticamente desprezada no estudo. Fatores circunstanciais contribuíram, porém para a avaliação de 18 pessoas integrantes de cinco famílias distintas. Apesar de o exame não abranger todos os componentes de cada grupo familiar, foi interessante constatar a presença de 
mais de um paciente com sulco palatogengival em uma mesma família, mais precisamente em três das cinco famílias abordadas.

Essa constatação abre a possibilidade para a realização de estudos abrangentes, que avaliem a presença do sulco palatogengival em grupos familiares. É importante ressaltar ainda que o estudo de várias gerações de uma família é dificultado pela possibilidade dos representantes mais velhos não possuírem os incisivos superiores. Outro tipo de estudo que pode ser desenvolvido é a avaliação do perfil quanto aos genes envolvidos com a odontogênese entre indivíduos de famílias de portadores do sulco palatogengival. O conhecimento gerado com esses estudos, certamente contribuiriam muito para a compreensão do tema.

A introdução para estudos moleculares de uma determinada condição geralmente passa por determinação precisa de heredogramas envolvendo várias gerações familiares. A pesquisa desta natureza em algumas poucas famílias é fundamental para justificar estudos moleculares envolvendo genes associados ao sulco palatogengival, pois deixariam de ser hipótese este envolvimento genético e passaria a ser fundamento metodológico e pressuposto para outras metodologias de investigação. Desta forma, em continuidade a este trabalho procuraremos identificar famílias com várias gerações onde seja possível verificar o padrão de comprometimento do sulco palatogengival.

As características dentárias são determinadas por muitas interações genéticas. Vários genes e mediadores participam na determinação de várias características morfológicas. Na anodontia parcial de qualquer dente, há implicações na morfologia dos demais dentes remanescentes ${ }^{101,141}{ }^{1}$. Muitos conhecimentos sobre genes envolvidos em determinada situação surgiram de manifestações simultâneas em pacientes sindrômicos. Desta forma sugere-se que trabalhos sejam desenvolvidos estudando a prevalência do sulco palatogengival em portadores de outros distúrbios do desenvolvimento da face e pescoço como fissurados, seqüência de Pierre Rubin, displasia cleidocraniana e pacientes anodônticos. 
A teoria da "tentativa" do germe dentário formar duas raízes ${ }^{82} \mathrm{e}$ resultar na formação do sulco palatogengival deve ser considerada, mas devese pensar que as raízes supranumerárias em incisivos superiores são raras como destacou SANTANA ${ }^{119}$ em 1989. O sulco se aprofundaria a ponto de formar uma raiz supranumerária ou a tentativa de formar uma raiz, desde que frustrada, geraria o sulco palatogengival? Se considerarmos a primeira possibilidade estamos admitindo o dobramento do germe antes de sua mineralização ter início. Mas, se considerarmos a segunda possibilidade, estamos admitindo que o fenômeno pode ser intrínseco à odontogênese e estaria associado à formação de raízes supranumerárias cuja etiopatogênese é muito pouco conhecida.

Uma vez comprovado em heredogramas bem fundamentados que 0 sulco palatogengival tem natureza familiar; evidenciando fortemente 0 envolvimento de mecanismos genéticos com a formação do sulco palatogengival durante a odontogênese, pode-se estabelecer protocolo de pesquisa direcionado ao assunto. Um estudo biomolecular que provavelmente esclareceria qual os genes envolvidos na formação do sulco palatogengival, poderia estudar a odontogênese de embriões ou fetos de cobras proteróglifas ou solenóglifas. Estas cobras que possuem as presas na região anterior da maxila, com sulco ou canal para inoculação do veneno. Essa análise se justificaria, pois a maioria dos genes envolvidos na odontogênese é do tipo homeobox, que são encontrados atuando de forma semelhante, em espécies de cadeia evolutiva diferentes ${ }^{36,37}$.

A figura 37 demonstra a morfologia dos sulcos e canais inoculadores nas cobras venenosas, talvez a resposta para muitas dúvidas sobre a morfogênese dentária estejam em estudos com outros modelos animais experimentais e sua possível relação com o sulco palatogengival. 

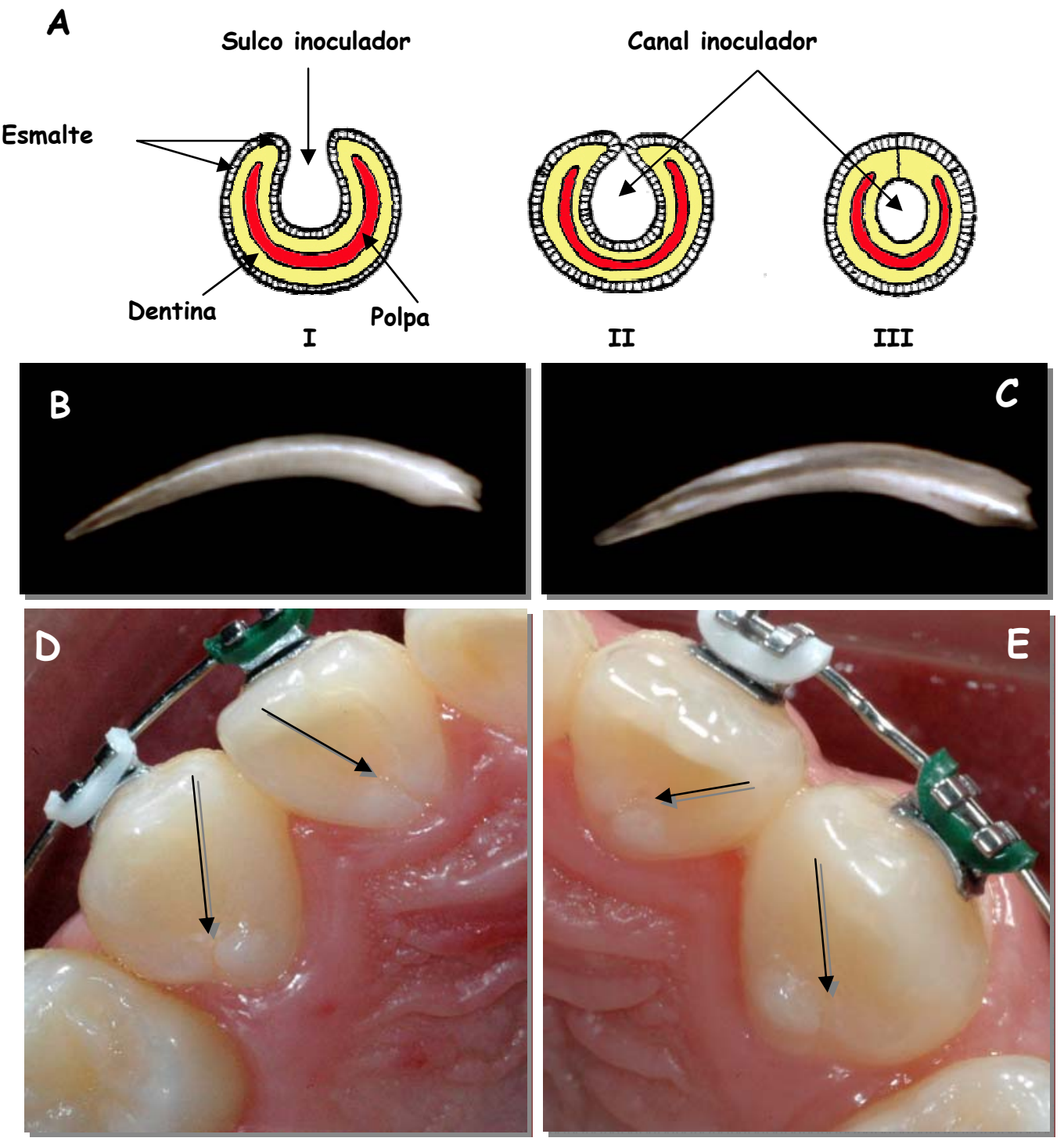

Figura 37 - A: Secções transversais das presas de cobras venenosas proteróglifas e solenóglifas segundo WIDDOWSON ${ }^{145}$ : Nota-se em A-I uma presa com sulco inoculador, típico das cobras marinhas do gênero Hydrophis; em A-II um tipo de presa onde o sulco forma um canal inoculador, como das cobras do gênero Cobra; em A-III uma presa com canal fechado, característico das vipirídeas solenóglifas. Nota-se ainda: $B$ : presa de uma cobra solenóglifa cascavel (Crotalus crotalus); C - a mesma presa após o desgaste longitudinal, revelando o canal inoculador de veneno (espécime preparado para ilustração da discussão deste trabalho). D e E Aspectos clínicos de um paciente com sulco palatogengival apresentando o sulco palatogengival bilateral nos incisivos laterais e caninos superiores. Esses dois caninos foram os únicos encontrados na casuística, porém não foram incluídos na 
pesquisa sendo demonstrados apenas para relacionar com as presas das cobras.

\subsubsection{Da parte B}

A seleção de uma amostra de 20 dentes com sulco palatogengival, tanto com incisivos laterais superiores quanto com incisivos centrais superiores, levou em consideração estudos que relataram a maior prevalência dos incisivos laterais superiores, mas também comprometendo os incisivos


os tipos dentários permite avaliar a influência das diferenças na morfologia dos canais radiculares, fator que poderia diminuir a importância dos achados experimentais em relação ao preparo biomecânico.

O sulco palatogengival foi considerado nesta dissertação uma entidade distinta do sulco vestibular vertical. Da mesma forma que LARA ${ }^{79}$ (1993) relatou a grande diversidade na nomenclatura do sulco palatogengival, o sulco vestibular vertical é também conhecido como: sulco radicular bucal, sulco radicular facial ou sulco labial-cervical-vertical. $O$ defeito tem aspecto semelhante ao sulco palatogengival, porém acomete preferencialmente os incisivos centrais superiores em sua face vestibular e pode ter a mesma etiopatogenia do sulco palatogengival ${ }^{63,87}$. Esta opção foi baseada na pouca quantidade de estudos sobre este defeito e a falta de um consenso que considere os sulcos como uma mesma entidade. Alguns estudos ${ }^{58,63,72,77}$ já relataram problemas periodontais acometendo incisivos superiores com sulcos vestibulares verticais, semelhantes aos encontrados em casos de sulco palatogengival. O estudo de prevalência de MASS et al. ${ }^{87}$ (2005), focou o sulco vestibular vertical, distinguindo-o do sulco palatogengival, e encontrou uma prevalência de $4,5 \%$ em 600 adolescentes.

Existem trabalhos que agregaram o sulco vestibular vertical à amostras de dentes com sulco palatogengival. LARA; CONSOLARO e BRUCE ${ }^{80}, 2000$ incluíram em sua amostra de 13 espécimes um incisivo central 
portador do sulco vestibular vertical. No trabalho de PÉCORA et al. ${ }^{105}$ (1991) os autores reportam que 8 dos 10 sulcos encontrados entre os 500 incisivos centrais avaliados estavam localizados na face vestibular. PÉCORA; CRUZ FILHO ${ }^{104}$ (1992) também consideraram os sulcos presentes tanto na face vestibular quanto na lingual em seu estudo epidemiológico.

As diferenças mais marcantes relacionadas às duas entidades são:

- O dente onde ocorrem mais freqüentemente: o sulco palatogengival acomete preferencialmente incisivos laterais e o sulco vestibular vertical acomete mais os incisivos centrais superiores;

- O início do defeito: o sulco palatogengival sempre se inicia na região do cíngulo, fossa e cristas marginais na face palatina do dente afetado, já o sulco vestibular vertical tem início na junção amelocementária da face vestibular dos dentes acometidos.

A classificação dos sulcos como uma só entidade, depende provavelmente de como o pesquisador encara o defeito, no que diz respeito à sua etiopatogenia. Se considerarmos a hipótese das forças de ATKINSON $^{9}$ é compreensível que a deformação do germe dentário ocorra de maneira semelhante entre os tipos dentários semelhantes e em diferentes faces de tipos dentários diferentes. Assim, provavelmente o germe de um incisivo lateral superior deformaria mais facilmente na face lingual devido sua posição indesejável entre os dentes: incisivo central, canino e pré-molar; em estágios mais avançados de mineralização. Porém nada se sabe qual fator causaria a deformação da face vestibular dos incisivos centrais pois não há um trabalho específico sobre a formação deste dente como há o trabalho sobre o incisivo lateral superior de ATKINSON ${ }^{9}$ em 1948.

Os achados macroscópicos do trabalho revelaram uma maior proporção da localização distal do sulco palatogengival (14:20). Estes dados são compatíveis com os dados de LARA; CONSOLARO e BRUCE ${ }^{80}$ (11:13) e de BAĈIĆ et al. ${ }^{13}$ (9:20). Outros trabalhos relataram mais sulcos localizados na face mediopalatal como HOU e TSAI ${ }^{67}$ (31:73) e KOGON ${ }^{75}$ (107:147). O tipo de sulco ou ruga estava presente na metade dos espécimes enquanto a forma 
mais branda e a mais intensa, depressão e fissura respectivamente, ocorreram em cinco dentes cada. O tipo do sulco indica sua profundidade, diretamente relacionada com as chances do desenvolvimento de doença periodontal, cárie e problemas endodônticos. Somente KOGON ${ }^{75}$ se preocupou em medir o comprimento do sulco e a maioria não se estendia além de $10 \mathrm{~mm}$. No presente trabalho optou-se por registrar-se a porção da raiz onde o sulco terminava de acordo com LARA ${ }^{79}$ na amostra 19 dos 20 espécimes com o sulco estendia-se ao terço médio ou apical.

Alterações no contorno da junção amelocementária, formando um degrau na região onde o sulco palatogengival à atravessa, estavam presentes em $15(75 \%)$ dos espécimes avaliados. Essas alterações foram inicialmente observadas por KOGON ${ }^{75}$ que encontrou tal alteração em $38 \%$ dos incisivos laterais e em $35 \%$ dos incisivos centrais avaliados. LARA; CONSOLARO e BRUCE ${ }^{80}$ observaram as mesmas alterações em 5 dos 13 dentes avaliados $(38,4 \%)$. O degrau da junção amelocementária pode ser considerado um fator deletério para a harmonia periodontal, pela possível alteração causada na inserção das fibras conjuntivas do ligamento periodontal, que provavelmente é dificultada. Alterações causadas por irregularidades entre o esmalte e o cemento na projeção cervical do esmalte têm implicações clínicas bem estabelecidas como doença periodontal localizada, pericoronarites e mesmo a formação de cistos paradentários ${ }^{91}$. O quadro agrava-se ainda mais, com a presença do sulco palatogengival, que propicia o acúmulo de placa dentobacteriana. Se considerarmos uma região com o sulco palatogengival, conjugado à junção amelocementária em forma de degrau, é aconselhável reconhecer uma predisposição natural à doença periodontal localizada nesta região. O degrau da junção amelocementária deve ser considerado nos incisivos superiores um sinal patognomônico de sulco palatogengival. Na dúvida sobre o diagnóstico do sulco palatogengival, a sondagem na junção e a detecção do degrau confirma o diagnóstico.

A observação dos espécimes à microscopia eletrônica de varredura revelou que os sítios da maioria dos acúmulos de cálculos dentários eram os sulcos palatogengivais. A porção coronária do sulco e a região onde o sulco 
atravessa a junção amelocementária apresentaram, cada uma, nove espécimes onde foi detectado o calculo dentário. Ainda, três espécimes revelaram cálculo dentário na porção radicular do sulco palatogengival, fator que indica que esses dentes já possuíam doença periodontal em estádio avançado quando foram extraídos. Tal observação reforça a importância da raspagem e do alisamento radicular, adjuntos da odontoplastia com remoção do sulco palatogengival ${ }^{90,141 .}$

A comunicação entre o compartimento periodontal e o compartimento pulpar relacionada ao sulco palatogengival foi destacado por PEIKOFF e TROTT ${ }^{107}$ (1977), GOON et al. ${ }^{57}$ (1991) e LARA; CONSOLARO e BRUCE ${ }^{80}$. Esses trabalhos avaliaram secções transversais dos dentes através de microscopia óptica. No primeiro trabalho de PEIKOFF; TROTT ${ }^{107}$ a possível comunicação entre a polpa e o periodonto, foi determinado por observações de cortes seriados de apenas um espécime tratado endodonticamente. É razoável suspeitar se realmente esta comunicação existia antes do tratamento endodôntico. GOON et al. ${ }^{57}$ fizeram a mesma observação, citando o achado de PEIKOFF; TROTT ${ }^{107}$, também a partir da avaliação de apenas um espécime atribuindo esta comunicação à presença de dentina displásica, com fendas e ilhas que pareciam comunicar os dois compartimentos.

$\mathrm{Na}$ figura 38 estão demonstradas as imagens dos artigos de PEIKOFF; TROTT ${ }^{107}$ e de GOON et al. ${ }^{57}$ para demonstrar que tais afirmações deveriam ter sido feitas com bastante cautela pelo risco da má interpretação dos cortes sem a consideração de possíveis artefatos de técnica também mal interpretados. 


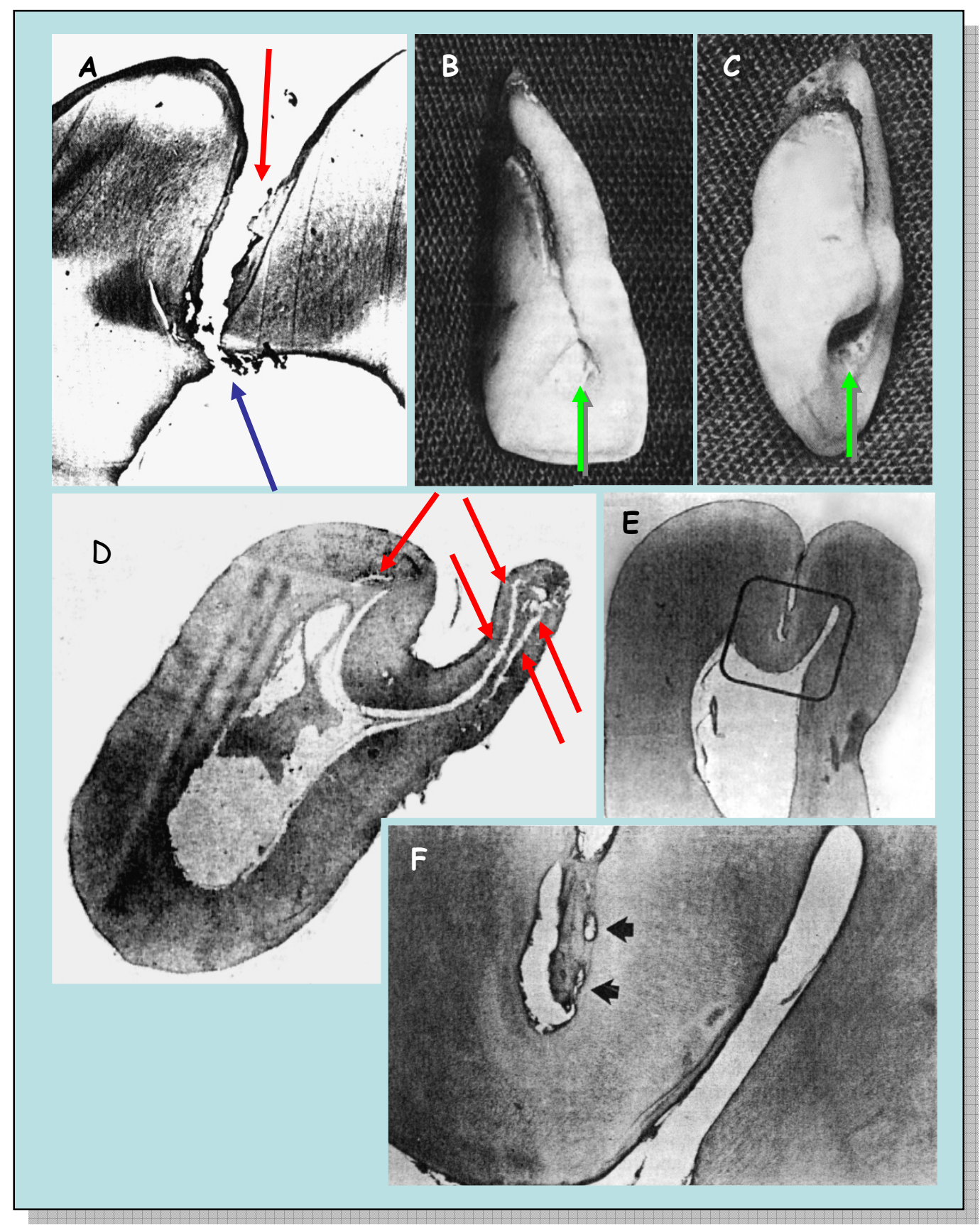

Figura 38 - Imagens dos artigos de PEIKOFF, TROTT ${ }^{107}$ A, B e C e de GOON et al. ${ }^{57}$ D, E e F. Observa-se na imagem A apontado pala seta vermelha uma região que pode ter perdido cemento durante o processamento laboratorial, dando a falsa impressão da extensão da profundidade do sulco, este indício é reforçado pela irregularidade em ângulos retos no contorno dos tecidos superficiais. A seta azul aponta a camada interna de dentina desgastada pela instrumentação, no artigo, os autores relatam que havia de 40-50 $\mu$ m de espessura de dentina separando o cemento do compartimento pulpar. 
Em B e C as setas verdes destacam a abertura coronária do dente que teve tratamento endodôntico. Na imagem D GOON et al ${ }^{57}$ atribuem às irregularidades apontadas pelas setas vermelhas o status de "rede de comunicações" entre o espaço periodontal e o canal radicular. Tais estruturas poderiam ser derivadas do corte ou da montagem da lâmina, porém não há como avaliar apropriadamente o corte, pois a imagem fornecida possui um aumento de $5 \mathrm{X}$, insuficiente para qualquer afirmação. E e F são outros cortes do mesmo espécime onde os autores afirmam que as setas negras apontam dentina displásica com fendas e ilhotas. Aumento original: $A-25 X, D-5 X, E-5 X$ e $F-10 X$

A existência de comunicações entre a polpa e o periodonto, foi evidenciada por GAO et al. ${ }^{53}$ em 1989. Havia foraminas e canais acessórios em pelo menos cinco dos 14 incisivos laterais avaliados através da microscopia eletrônica de varredura. Não constataram a completa ausência de tecidos dentários entre o sulco e a cavidade pulpar, atribuindo às foraminas e aos forames acessórios a principal fonte de comunicação entre estes compartimentos.

O método de avaliação dos espécimes mostrou-se eficiente e sólido, para embasar as afirmações de GAO et al. ${ }^{53}$. Por outro lado, algumas dificuldades conceituais puderam ser notadas. Os autores consideraram foraminas, orifícios na dentina de $4 \mu \mathrm{m}$, compatíveis com túbulos dentinários para HESS; CULIERAS e LAMIABLE ${ }^{65}$ (1983). Mesmo assim, relataram que a maioria das foraminas encontradas tinham diâmetros variando entre 15 a $200 \mu \mathrm{m}$.

Também observamos comunicações entre a polpa e o periodonto em seis dos 20 espécimes avaliados. Eram túbulos dentinários expostos, foraminas acessórias e, em um espécime, um forame lateral. Esta relação deve ser considerada no planejamento do tratamento periodontal e endodôntico de dentes com sulco palatogengival, pois desengatilham insucessos quando não acessadas ao mesmo tempo em que facilita a ação de medicamentos nos dois compartimentos, promovendo o reparo. 
O tipo de junção amelocementária na região do sulco palatogengival seguiu os critérios de NEUVALD e CONSOLARO ${ }^{97}$. A relação entre o esmalte e o cemento seguiu os mesmos padrões do referido trabalho, variando entre os três tipos no percurso da junção na circunferência do dente. Na região do sulco palatogengival, o tipo mais comum de junção amelocementária foi o topo-atopo, presente em 10 dos 20 espécimes, o tipo "gap" acometeu cinco e em outros cinco dentes observou-se o cemento recobrindo o esmalte. Uma constatação importante foi a grande dificuldade de estabelecer o tipo de junção amelocementária presente em sulcos muito profundos. Talvez, nestes casos, ocorra uma interrupção da junção, porém não se pode afirmar com certeza a presença desta alteração, baseado apenas nos achados da microscopia eletrônica de varredura.

As reabsorções dentárias identificadas em 10 espécimes ocorreram muito mais nos terços médio e apical do dente. Este achado alerta quanto ao comprometimento pulpar desses espécimes antes de serem extraídos. É possível, que durante a evolução do quadro periodontal dos dentes com sulco palatogengival, ocorra uma perda rápida de inserção conjuntiva no terço cervical, onde geralmente o sulco é mais profundo. Com o avanço da doença e cronicidade da agressão estimula-se o estabelecimento de BMUs, na superfície radicular. Quando houver a periapicopatia crônica, a ocorrência de reabsorções apicais é comum, o que e deve explicar aquelas encontradas na amostra.

A análise sistemática dos 47 casos relatados na literatura ${ }^{109}$ revelou em $50 \%$ dos casos, em que o incisivo acometido pelo sulco necessitou de tratamento endodôntico, evoluiu para o insucesso clínico, seguido da necessidade de extração. Esse dado estimulou o entendimento da morfologia do sistema de canais radiculares de dentes portadores do sulco. Se considerarmos que o sulco palatogengival não tem comunicação direta com a polpa apenas por foraminas não há contaminação no sentido periodonto para a polpa. Assim, o envolvimento pulpar é secundário ao periodontal por via apical, em alguns casos avançando até com a periodontite crônica.

Os resultados obtidos demonstraram que a espessura de dentina entre o fundo do sulco palatogengival e o canal radicular é menor que as 
espessuras de outras regiões da superfície radicular, antes e depois do preparo biomecânico. O desgaste produzido pelo preparo biomecânico, porém, tende a ser uniforme não havendo diferença estatisticamente significante entre as medidas efetuadas a partir de diferentes pontos da superfície radicular. $O$ desgaste uniforme das paredes, com valores semelhantes em todas as medidas de todas as secções dos espécimes, serve de alerta quanto aos riscos de perfuração no terço apical que possui paredes de dentina mais finas, assim um desgaste de $0,1 \mathrm{~mm}$, por exemplo, é mais seguro numa parede do terço cervical do que em uma parede do terço apical, devido à diferença entre suas espessuras. Mas o endodontista deve estar alerta em todos os terços do dente com sulco palatogengival pois a parede relacionada ao sulco, ficaria mais fina que as demais.

Um fator que pode ter sido determinante na regularidade dos desgastes, é que a amostra era, grande parte, composta por dentes sem curvatura, ou com pouca curvatura com anatomia de seus canais semelhante à de qualquer incisivo superior. BELLUCCI; PERRINI ${ }^{19}$, ao avaliarem a espessura da dentina radicular e do cemento em dentes anteriores, verificaram que as secções de incisivos centrais superiores são geralmente circulares ou levemente triangulares, já os incisivos laterais superiores, são mais achatados no sentido mesiodistal com canal com forma mais ovalar.

Mesmo assim, foi possível observar que, em alguns espécimes, uma parede foi mais instrumentada que as outras. Em outros casos, de canais com forma de secção oval, houve paredes que praticamente não sofreram ação dos instrumentos. Para WU et al. ${ }^{147}$ é comum que em canais com forma oval a instrumentação remova apenas de 40-60\% da camada interna de dentina, variando essa quantidade de acordo com a técnica empregada.

As dilacerações radiculares foram detectadas em sete dos 20 espécimes do estudo, sendo a mais acentuada no espécime $n^{\circ} 2$. Nestes casos, o uso das fresas Gates-Glidden e o emprego das limas Nitiflex, junto às limas flexofile proporcionaram um preparo anti-curvatura, pelo direcionamento da instrumentação para as zonas de segurança e evitando a instrumentação 
excessivas das zonas de risco, mais próximas ao sulco palatogengival, de acordo com o preconizado por ABOU-RASS et al. ${ }^{1}$.

A avaliação da instrumentação em três diferentes pontos do canal radicular tentou distinguir fatores isolados na alteração da morfologia do conduto nos terços cervical, médio e apical do incisivo com sulco palatogengival. Foi possível constatar tanto no grupo experimental quanto no grupo controle que a forma do canal radicular torna-se mais arredondada nas secções apicais dos espécimes, uma observação de acordo com os estudos anatômicos de DE DEUS ${ }^{42}$.

A técnica de instrumentação utilizada no trabalho seguiu os preceitos de LEONARDO; LEAL ${ }^{84}$, realizando a instrumentação com dilatação dos dois terços coronários do canal radicular com auxilio de fresas especiais complementada com escalonamento. Tal escolha se deve a consonância da técnica com conceitos sólidos da literatura internacional através dos trabalhos de CHRISTIE; PEIKOFF ${ }^{34}$ (1980), ABOU-RASS et al. ${ }^{1}$ (1980), GOERIG et al. 56 (1982).

Neste estudo não comparou diferentes técnicas de instrumentação, nem tão pouco diferentes tipos de instrumentos rotatórios de ligas de NíquelTitânio. A conicidade obtida pelos preparos é compatível às limas de taper $0,2 \mathrm{~mm}$, do instrumento de memória e do recuo progressivo anatômico empregados em todos os espécimes. A constatação da possibilidade do emprego de instrumentos rotatórios no modelo de muflas modificado de BRAMANTE et al. ${ }^{25}$, traz perspectivas para novos estudos de instrumentação tanto em dentes com canais retos ou curvos quanto no estudo de dentes com anatomia, radicular e de seus canais, peculiares como o caso de incisivos com sulco palatogengival e dentes com canal oval ou "C-shape".

A análise comparativa da morfologia do canal dos dentes da amostra antes e depois do preparo biomecânico foi estabelecida utilizando uma modificação na técnica da mufla de BORGES ${ }^{21}$. Mesmo levando em consideração os outros métodos para este tipo de análise $20,22,30,41,47,86,128,133,143,147,149$, desenvolvidos a partir do trabalho de BRAMANTE et al. ${ }^{25}$, não foi possível 
constatar uma vantagem significante, para que se optasse por um ou outro método, em detrimento ao primeiro. Assim, a modificação da técnica proposta no presente trabalho, pode ser muito bem encarada como um aprimoramento apenas. A execução das alterações propostas proporcionou:

$>$ Padronização dos blocos de resina com formato de prisma de base hexagonal com superfície lisa e polida, resultando em blocos de fácil desinclusão do gesso, eliminando o risco de fratura das guias estabilizadoras;

> Ótima estabilidade do bloco dentro da mufla de gesso, mesmo depois de seccionado;

$>$ Diminuição na quantidade de bolhas internas no bloco de resina devido à polimerização a frio e sob pressão da resina;

$>\quad$ Agilidade na confecção das muflas de gesso pela utilização de diques de cera rosa $n^{07}$ invés de forma de madeira, que dificulta 0 deslocamento do gesso após sua presa;

> Diminuição da quantidade de dente perdida na secção dos blocos, devido à utilização de um disco mais fino $(0,3 \mathrm{~mm}$ de espessura);

> Facilidade na comparação das alterações na morfologia dos canais antes e depois da instrumentação agregada pela análise à microscopia eletrônica de varredura;

$>$ Precisão dos resultados pela análise digital das imagens com auxílio de software especializado. 


\subsection{Da importância clínica}

\subsubsection{Da parte A}

O presente estudo demonstrou que a presença do sulco palatogengival pode ser mais freqüente do que se relata na literatura especializada, baseado na prevalência encontrada no exame de 500 pacientes sob assistência odontológica. Os pacientes examinados não tinham conhecimento do defeito, nem os profissionais que os tratam. Mesmo os pacientes que tiveram sulcos palatogengivais diagnosticados, informaram que nunca tiveram um exame direcionado à identificação da alteração pelos profissionais. O conhecimento sobre o assunto deve, ser mais difundido e incluído na formação dos profissionais.

O atendimento clínico oferecido aos portadores do sulco palatogengival examinados e diagnosticados com problemas periodontais e de dentisteria foi de grande valia para a compreensão do problema e do exercício das diferentes técnicas já relatadas na literatura, para o manejo das intercorrências patológicas produzidas. Não foram raros os casos de restaurações inadequadas na área do sulco palatogengival.

Baseado na análise sistemática de 47 casos relatados na literatura 109 e nos 39 pacientes do presente trabalho com alguma alteração dentária decorrente do sulco palatogengival,propusemos o seguinte protocolo de condutas terapêuticas e preventivas em pacientes com sulco palatogengival:

1. Pacientes sem alterações clínicas: Nestes pacientes deve-se avaliar a profundidade do sulco, o acesso ao sulco, que pode estar em região de apinhamento dentário e conscientizar o paciente quanto aos cuidados de prevenção que deverão ser feitos no cotidiano: utilização de fio dental pelo menos uma vez ao dia; escovação da face palatina dos dentes anteriores, muitas vezes negligenciadas na escovação. Acompanhamento clínico periódico por um profissional consciente. 
2. Pacientes com cárie no sulco: Remoção do sulco palatogengival com brocas diamantadas esféricas compatíveis ao tamanho do sulco, aplainando a extensão radicular do sulco com brocas cilíndricas multilaminadas para polimento e restauração com resina composta com isolamento absoluto. Acompanhamento clínico periódico por um profissional consciente.

3. Pacientes com doença periodontal sem perda óssea: Odontoplastia com eliminação do sulco ou saucerização*, raspagem e alisamento radicular (figura 39). Restauração com resina composta da porção coronária do sulco caso este seja muito profundo. Acompanhamento clínico periódico por um profissional consciente.

4. Pacientes com doença periodontal com perda óssea: Retalho total para identificação do defeito (figura 40), remoção do tecido de granulação contaminado da região do sulco, osteoplastia, raspagem e alisamento radicular, odontoplastia para remoção do sulco, condicionamento radicular com ácido cítrico $\mathrm{PH}=1$, na área comprometida, para diminuir a contaminação bacteriana e ou LPS (lipopolissacarídeos), posicionamento de membrana para a regeneração epitelial e reparação conjuntiva e óssea guiada. Restauração com resina composta da porção coronária do sulco. Acompanhamento clínico periódico por um profissional consciente.

5. Pacientes com envolvimento endodôntico: Eliminar qualquer problema periodontal que o dente possa apresentar como mencionado anteriormente, juntamente com o tratamento endodôntico. Atentar-se para a possibilidade da presença de duas raízes e dois canais radiculares. Restauração com resina composta da porção coronária do sulco eliminando-o. Acompanhamento clínico periódico por um profissional consciente.

\footnotetext{
* Do inglês "saucerization": erosão rasa de um tecido com forma de pires.
} 
6. Casos com raiz acessória com doença periodontal elou envolvimento endodôntico: Dependendo do grau de envolvimento periodontal e do tamanho da raiz realizar raspagem e alisamento da área do sulco e ou remoção cirúrgica da raiz, odontoplastia, selamento com MTA (agregado de trióxido mineral) de qualquer comunicação que possa haver com o canal principal do dente. Eliminação da porção coronária do sulco com restauração com resina composta. Acompanhamento clínico periódico por um profissional consciente.

7. Casos de insucesso: Quando as modalidades terapêuticas se esvaírem, sem um resultado clínico satisfatório, a exodontia está indicada. Esse tratamento é a última escolha e não deve ser cogitado antes dos tratamentos propostos, ao contrário do que inicialmente se praticava. Ao considerar o problema como não tratável EVERET; KRAMER ${ }^{48}$, ABOYANS; GHAEMMAGHAMI ${ }^{3}$ e AUGUST $^{8}$ indicaram a extração imediata do dente envolvido. No local pode-se fechar o espaço com soluções ortodônticas protéticas ou implantodônticas. 

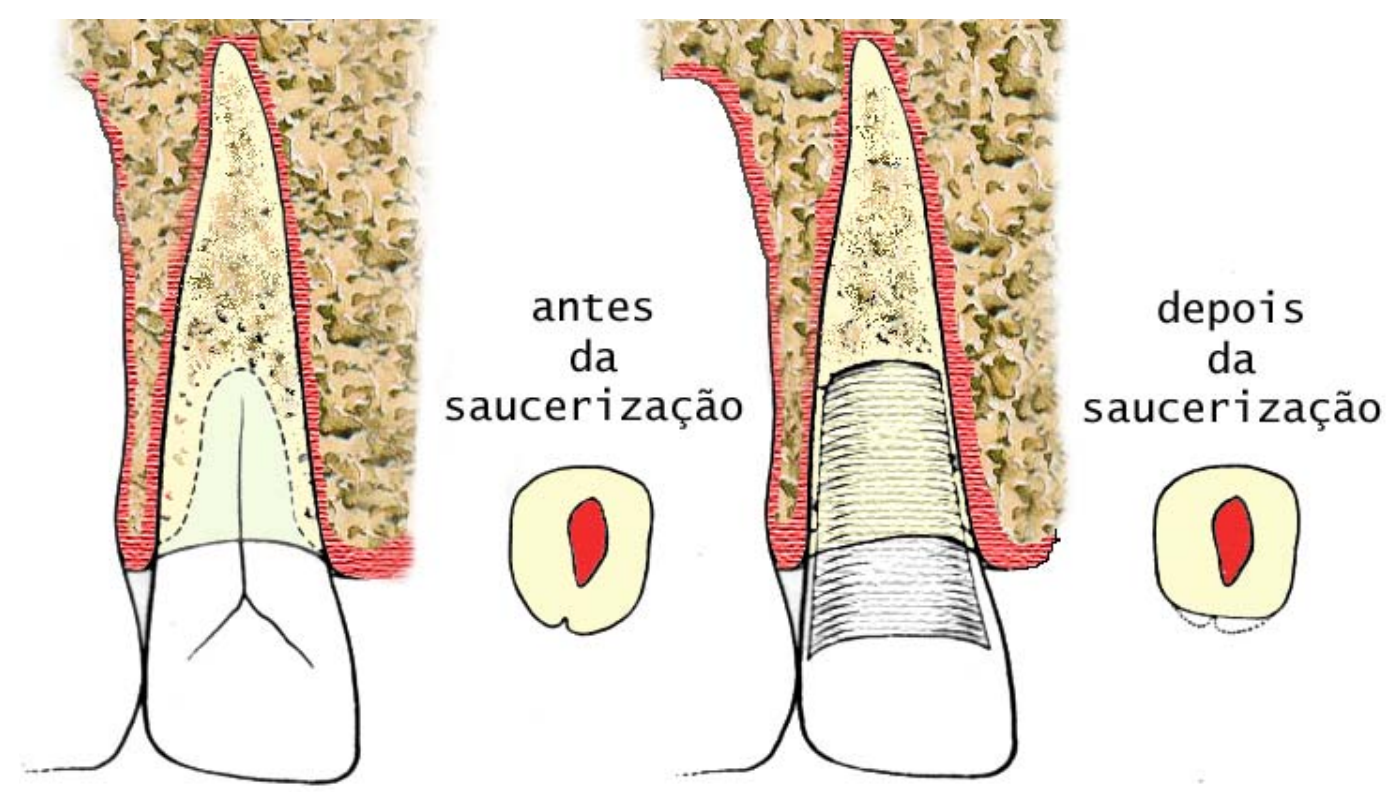

Figura 39 - Representação esquemática da odontoplastia na região do sulco com doença periodontal localizada a partir de ROBISON; COOLEY ${ }^{116}$



Figura 40 - Retalho total revelando o defeito ósseo relacionado ao sulco palatogengival profundo. Cedido pelo Prof. Dr. Armelindo Roldi e pelo Prof. Alfredo Feitosa - UFES 


\subsubsection{Da parte B}

O estudo da superfície radicular dos 20 espécimes avaliados no trabalho revelou que seis deles apresentavam algum tipo de comunicação entre o compartimento pulpar e periodontal. Essas comunicações eram principalmente forames laterais e foraminas acessórias, e explicam a presença do cimento obturador encontrado no leito do sulco por PEIKOFF, PERRY e CHAPNICK ${ }^{108}$ e por SANTA CECÍLIA et al. ${ }^{118}$. O conceito de fendas na dentina causadas pelo sulco palatogengival de acordo com PEIKOFF e TROTT 107 e de PEIKOFF, PERRY e CHAPNICK ${ }^{108}$ não se sustenta após a realização do presente estudo. Tal tipo de comunicação não foi observado em nenhum dos 20 espécimes avaliados. É interessante ressaltar que, o conceito proferido nos referidos artigos ${ }^{107,108}$, baseia-se na avaliação de secções microscópicas transversais em cortes corados em H.E. de apenas um dente, em cada artigo.

É muito provável, que o cimento encontrado na superfície do leito dos sulcos relatados foram extravasado por canais laterais ou foraminas acessórias, que se abriam no sulco ou ainda até penetrado pelo sulco a durante a obturação pelo espaço periodontal. São conceitos equivocados que se difundiram em quase todos os trabalhos sobre sulco palatogengival, sem terem sido comprovados através de metodologia apropriada.

Essas comunicações de PEIKOFF e TROTT ${ }^{107}$ entre a polpa e o periodonto no perímetro do sulco palatogengival não devem ser consideradas tanto na terapia periodontal quanto endodôntica. Se um dente com sulco palatogengival apresenta-se sem vitalidade com nenhuma causa aparente, porém com bolsa periodontal profunda na região do sulco, é recomendável a terapia endodôntica combinada com a periodontal como relatada nos trabalhos de MEISTER et al. ${ }^{90}$ e GAUND; MAZE ${ }^{58}$. Esses casos são periodontopatias inflamatórias associadas ao sulco palatogengival com envolvimento endodôntico secundário via apical da polpa dentária podendo gerar por conseqüência lesões periapicais crônicas. Dessa forma, elimina-se o risco da manutenção de substrato para a o processo infeccioso microbiano na região. 
O extravasamento de soluções irrigadoras, medicamentos intracanal e cimento endodôntico pelas comunicações entre a polpa e o periodonto relacionadas ao sulco, podem representar agentes agressores químicos e físicos, que dificultariam o restabelecimento da saúde periodontal. Más, se o componente infeccioso for devidamente combatido, não há nenhum indício na literatura que leve a pensar no insucesso do tratamento. GAO et al. ${ }^{53}$ relata que a maioria das lesões periodontais com envolvimento endodôntico secundário associado ao sulco palatogengival podem ser tratadas com sucesso, desde que a infecção presente nos canais acessórios seja eliminada pela obliteração dos canais, com seladores desinfetantes, e as substâncias infectadas presentes no sulco palatogengival possam ser removidas de maneira eficaz através da cirurgia periodontal.

O degrau causado na junção amelocementária pelo sulco palatogengival, aliado a possíveis interrupções em sua continuidade, devem ser encarados como ameaças a saúde periodontal tão importantes quanto a presença do sulco per si. A odontoplastia e restauração com resina composta, proporcionando uma anatomia compatível com a saúde do periodonto, são recomendáveis para estes casos.

É desaconselhável a aplicação de agentes clareadores, utilizados na clareação interna, em dentes com sulco palatogengival. Além de possuírem uma região da junção amelocementária fragilizada pela presença do sulco, os incisivos portadores podem ainda apresentar a junção com relação entre o esmalte e o cemento do tipo "gap", que expõe túbulos dentinários e facilita a instalação de processos reabsortivos na região ${ }^{39,} 97$. Caso opte-se pela realização da clareação externa o acompanhamento clínico e controle radiográfico deve ser feito em intervalos curtos de tempo. Não se tem dados na literatura sobre a quantidade de incisivos centrais e laterais superiores que tenham apresentado reabsorção cervical externa pós clareação interna e que tinham sulco palatogengival.

A constatação de menor espessura de dentina na parede do sulco palatogengival observadas nos 20 espécimes avaliados à microscopia 
eletrônica de varredura trás algumas implicações clínicas que devem ser relevadas:

1. Quando houver a necessidade de tratamento endodôntico de um incisivo portador do defeito, o profissional deve avaliar a profundidade do sulco, para planejar uma instrumentação com um alargamento moderado do conduto, evitando assim um possível "rasgo" do canal radicular, como foi observado no trabalho de PEIKOFF, TROTT 107. Nenhum dos 20 espécimes avaliados apresentou rasgos ou perfurações detectadas radiograficamente ou nas secções transversais, isto indica que o evento é razoavelmente difícil de acontecer na prática clínica cotidiana;

2. Outro fator que deve ser considerado é a necessidade do preparo do canal para pino em que se procura estabelecer critérios para a dilatação dos canais, tendo em vista o não comprometimento da raiz. Caso seja necessário esse procedimento na raiz de incisivos com sulco palatogengival, no mínimo $7 \mathrm{~mm}$ de guta-percha devem ser deixados no interior do canal, a fim de minimizar a possibilidade de fraturas verticais. Mesmo assim, deve ser desencorajado o preparo para a contenção intra-radicular nesses dentes para minimizar os riscos do tratamento. ${ }^{30}$, 133. Na literatura não se tem o dado de quantos incisivos centrais e laterais superiores que sofreram fraturas causadas por pinos e apresentavam o sulco palatogengival;

3. O desgaste da superfície externa da raiz na região do sulco palatogengival no procedimento de odontoplastia deve ater-se ao aplainamento da região, para que a espessura da dentina remanescente não se torne menor ainda que a já diminuída entre o fundo do sulco e o interior do canal. 
CONCLUSÕES 


\section{CONCLUSÕES}

Diante dos resultados obtidos, e respeitando-se as limitações da metodologia empregada, é possível concluir que:

\section{Parte A:}

a) A prevalência do sulco palatogengival na amostra de 500 pacientes avaliados, foi de $19,8 \%$, sendo que o dente mais afetado foi o incisivo lateral superior com $80,4 \%$ de prevalência, ocorrendo tanto unilateralmente, quanto bilateralmente. Observou-se a prevalência de $7,8 \%$ de doenças relacionadas ao sulco. Não foram detectadas diferenças entre gêneros e cor de pele, quanto à presença do defeito;

b) Também, nenhuma correlação entre a presença do sulco palatogengival e as características físicas: tipo facial, relação entre os arcos e forma do arco dentário; foram observadas. Foram identificadas presenças do sulco palatogengival em mais de um integrante de três das cinco famílias avaliadas;

c) É possível estabelecer protocolos pré-definidos para cada situação clínica relacionada ao sulco palatogengival;

d) A comparação crítica dos achados deste estudo com relatos da literatura estimulam a realização de estudos mais aprofundados que auxiliem no entendimento da etiopatogenia do sulco palatogengival;

e) A maior difusão do conhecimento sobre o sulco palatogengival é necessária e preponderante. 


\section{Parte B:}

a) A análise da morfologia externa e interna de 20 incisivos superiores com sulco palatogengival permitiu a identificação de forames, foraminas e túbulos dentinários no leito do sulco palatogengival, comunicando o compartimento pulpar com o periodontal;

b) A parede dentinária atingida pelo sulco palatogengival foi a mais fina antes e depois do preparo biomecânico, de acordo com a análise estatística de variância, apesar do desgaste produzido pela instrumentação dos canais nos dentes da amostra ter sido estatisticamente uniforme;

c) Identificaram-se alterações no contorno e variações do tipo de junção amelocementária que servem de nicho onde microorganismos que infectam o sulco possam se estabelecer, causando danos periodontais e endodônticos. 
$\mathcal{A N E X O S}$ 


\section{ANEXO 1 \\ Ficha utilizada para registro dos pacientes \\ Universidade de São Paulo \\ Faculdade de Odontologia de Bauru}

Al. Dr. Octávio Pinheiro Brisolla, 9-75 - Bauru-SP

CEP $17012-901$ - C.P. 73

PABX (0XX14)235-8000 - FAX (0XX14)223-4679

NOME:

ENDEREÇO:

GÊNERO:

IDADE:

COR DA PELE:

\section{FICHA CLÍNICA}

SULCO PALATOGENGIVAL:

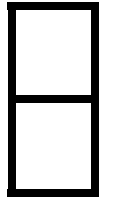

TIPO FACIAL:

DOLICOCEFÁLICO

BRAQUICEFÁLICO

MESOCEFÁLICO

RELAÇÃO ENTRE OS ARCOS:

CLASSE I

CLASSE /I

CLASSE III
PRESENTE Dente $\mathrm{n}^{\mathrm{o}}$

$\mathrm{RX}$ :

AUSENTE Sondagem: $\mathrm{mm}$

TIPO DE ARCO DENTÁRIO:

TRIANGULAR
QUADRADO
OVALAR

HISTÓRICO FAMILIAR:

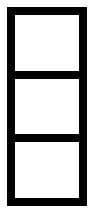

PRESENTE

AUSENTE

$N \tilde{O} O$ SABE

OBSERVAÇÕES: 


\author{
ANEXO 2 \\ Carta de informação ao paciente \\ Universidade de São Paulo \\ Faculdade de Odontologia de Bauru \\ Al. Dr. Octávio Pinheiro Brisolla, 9-75 - Bauru-SP - CEP 17012-901 - \\ C.P. 73 \\ PABX (0XX14)235-8000 - FAX (0XX14)223-4679
}

\title{
CARTA DE INFORMAÇÃO AO PACIENTE
}

Este trabalho analisará os seus dentes incisivos superiores na sua parte posterior, pois pode ter um sulco ou depressão a mais do que o normal.

A descoberta deste sulco no seu dente é importante porque você passará a escovar melhor nesta região, que sem um cuidado especial poderá desenvolver cárie e doença gengival com conseqüências que variam de necessidade de restauração, cirurgia e até perda do dente.

Em nossa pesquisa queremos examinar seus dentes e uma vez descoberto o sulco fotografaremos apenas os dentes, realizaremos algumas perguntas e se necessário tiraremos radiografias periapicais. Se você for portador, te orientaremos quanto à forma de escovar corretamente a região prevenindo de futuros problemas. No caso de alguma dessas doenças for identificadas, poderão ser tratadas gratuitamente se assim for do seu interesse.

Recebi as informações referentes aos procedimentos através do Cirurgião Dentista Tiago Novaes Pinheiro junto com convite para participar da pesquisa e garantia de sigilo, reconhecendo a relevância de cunho científico por ele realizado. Diante dos esclarecimentos concordo participar dessa pesquisa e que não causará nenhum dano a minha pessoa.

Por estarem de acordo assinam o presente termo.

Bauru-SP, de de. 


\section{REFER $\hat{E} \mathcal{N} C I \mathcal{A} S$ BIBLIOGRÁfICAS}




\section{REFERÊNCIAS BIBLIOGRÁFICAS*}

ABOU-RASS, M.; FRANK, A.L.; GLICK, D.H. The anticurvature filing method to prepare the curved root canal. J Am Dent Assoc, v. 101, n.11, p. 792-4, Nov.1980.

ABOU-RASS, M.; JASTRAB, R.J. The use of rotatory instruments as auxiliary aids to root canal preparation of molars. J Endod, v. 8, n. 2, p. 78-82, Feb. 1982.

ABOYANS, V.; GHAEMMAGHAMI, A. Two developmental anomalies as potential causes of periapical pathosis. J Oral Med, v. 31, n. 3, p. 63-6, July-Sep. 1976.

ANDERGG, C.R.; METZLER, D.G. Treatment of the Palato-Gengival Groove With Guided Tissue Regeneration. Report of 10 Cases. J Periodontol, v. 64, n. 1, p.72-4, Jan. 1993.

ANDREANA, S. A Combined Approach for Treatment of Developmental Groove Associated Periodontotal Defect. A Case Report. J Periodontol, v. 69, n. 2, p. 601-7, May 1998.

ANGLE, E.D. Classification of malocclusion. Dent Cosmos, v. 41, p. 248-64, 1899.

ASSAF, M.E.; ROLLER, N. The Cingulo-Radicular Groove: Its Significance and Manegement-Two Case Reports. Compend Contin Educ Dent, v. 13, n. 2, p. 94-100, Feb. 1992.

\footnotetext{
*Normas recomendadas para o uso no âmbito da Universidade de São Paulo, com base no documento "Referências Bibliográficas: exemplos", emanados do Conselho Supervisor do Sistema Integrado de Bibliotecas da USP em reunião de 20 de setembro de 1990.
} 
8 AUGUST, D.S. The radicular lingual groove: an overlooked differential diagnosis. J Am Dent Assoc, v. 96, n. 6, p. 1037-9, Jun. 1978.

9 ATKINSON, S.R. The permanent maxillary lateral incisor. Am J Orthod, v. 29, n. 12, p. 685-98, Dec. 1943.

10 . Changing dynamics of the growing face. Am J Orthod, v. 35, n. 11, p. 815-836, Nov. 1949.

AWAZAWA, Y. et al. Patho-morphological study of the supplemental groove. Bull Group Int Rech Sci Stomatol Odontol, v. 32, n. 3, p. 145- 56, 1989.

BAIDAS, L.; HASHIM, H. An Anterior Tooth Size Comparison in Unilateral and Bilateral Congenitally Absent Maxillary Lateral Incisors. J Contemp Dent Pract, v. 6, n. 1, p. 56-63, Feb. 2005.

BAČIĆ, M. et al. The association between palatal grooves in upper incisors and periodontal complications. J Periodontol, v. 61, n. 3, p. 197-9, Mar. 1990.

BARKER, B.C.W. A two rooted permanent maxillary median incisor. Aust Dent J, v. 9, n. 6, p. 501, Dec. 1964. Dental anthropology: some variations and anomalies in human tooth form. Aust Dent J, v. 18, n. 3, p. 132-40, June 1973.

BEI, M.; KRATOCHWIL, K.; MAAS, R.L. BMP4 rescues a noncellautonomous function of Msx1 in tooth development. Development , v. 127, n. 21, p. 4711-8, Nov. 2000.

17 BENENATI, F.W. Maxillary second molar with two palatal canals and a palatogengival groove. J Endod, v. 11, n. 7, p. 308-10, July 1985. 
BENNETT, J.C.; MCLAUGHLIN, R.P. Arch form considerations for stability and esthetics. Rev Esp Ortod, v. 29, n. 2, p. 46-63, 1999.

BERLLUCCI, C.; PERRINI, N. A study on the thickness of radicular dentine and cementum in anterior and premolar teeth. Int Endod J, v. 35, n. 7, p.594-606, June 2002.

BLITZKOW G.S.; BATISTA, A.; LOUREIRO DE MELO L. The radiographic platform: a new method to evaluate root canal preparation in vitro. J Endod, v. 17, n. 11, p. 570-2, Nov. 1991.

21 BORGES, R.P. Análise Anátomo-Cirúrgica das técnicas de instrumentação convencional, telescópica e de Christie \& Peikoff. Bauru, 1985. 127 p. Dissertação (Mestrado) Faculdade de Odontologia de Bauru, Universidade de São Paulo.

22 BOLANOS, O.R.; JENSEN, J.R. Scanning electron microscope comparisons of the efficacy of various methods of root canal preparation. J Endod, v. 6, n.11, p. 815-21, Nov.1980.

23 BRABANT, H.; KLEES, L.; WERELDS, R. J. Anomalies, mutilations et tumeurs des dents humaines. Paris, Julies Prélat, 1958. p. 867 e 423.

24 BRABANT, $\mathrm{H}$. The human dentition during the Megalithic Era. In: DAHLBERG, A.A. Dental morphology and evolution. Chicago, University of Chicago Press, 1971

25 BRAMANTE, C.M.; BERBERT, A.; BORGES, R.P. A methodology for evaluation of root canal instrumentation. J Endod, v. 13, n. 5, p. 243-5, May 1987. 
26 BROOMELL, I.N.; FISCHELIS, P. Anatomy and histology of the mouth and teeth. 5.ed. Philadelphia, Blakiston's Son \& Co, 1917, p.115

27 BRUNSVOLD, M.A. Amalgam restoration of a palatogengival groove. Gen Dent, v. 33,n. 3, p. 244-6, May-June 1985.

28 Palato-gengival grooves: Hidden etiologic factors of periodontitis. Tex Dent J, v. 108, n. 1, p. 27-31, Jan. 1991.

29 CAMPBELL, T.D. Dentition and palate of the australian aboriginal. Adelaide, Hassell, 1925.

30 CARAM, C.M.; BIFFI, J.C.G. Avaliação do sulco longitudinal em prémolares superiores no preparo do canal radicular. Rev Assoc Paul Cir Dent, v. 59, n. 2, p. 101-5, Mar-Abr. 2005.

31 CARdoso, A. Incisivo fissurado. Rev Assoc Paul Cir Dent, v. 40, n. 4, p. 286-8, Jul-Ago. 1986.

32 CHIRINOS, E.F. Estomatologia forense. Lima, Universidad Nacional Mayor de San Marcos. Facultad de Odontologia, 1994.

33 CHRISTIE, W.H.; HOLTHUIS, A.F. The endo-perio problem in dental practice: Diagnosis and prognosis. J Can Dent Assoc, v. 56, n. 11, p. 1005-11, Nov. 1990.

34 CHRISTIE, W.H.; PEIKOFF, M.D. Conservative treatment of apical foramen new root canal thecniques. J Can Dent Assoc, v. 43, n. 3, p. 183-8, Mar. 1980. 
CHRISTIE, W.H.; PEIKOFF, M.D.; ACHESON, D.W. Endodontic treatment of two maxillary lateral incisors with anomlous root formation. J Endod, v. 7, n. 11, p. 528-34, Nov. 1981.

36 COBOURNE, M.T.; SHARPE, P.T. Morphogenesis development (costwg2). Expression and regulation of hedgehog-interacting protein during early tooth development. Connect Tissue Res, v. 43, n. 2-3, p. 143-7, 2002. . Tooth and jaw: Molecular mecanisms of pettering in the first branchial arch. Arch Oral Biol, v. 48, n. 1, p. 1-14, Jan. 2003. hedgehog signalling during early tooth development. Dev, v. 131, n. 12, p. 2875-85, June 2004. clínicas. Maringá, Dental Press, 2002. antisense transcript during development. Nucleic Acids Res, v. 33, n. 16, p. 5208-18, Sep. 2005.

41 DAVIS, S.R.; BRAYTON, S.M.; GOLDMAN, M. The morphology of the prepared root canal: a study utilizing injectable silicone. Oral Surg Oral Med Oral Pathol, v. 34, n.4, p. 642-8, Oct. 1972.

42 DE DEUS, Q.D. Endodontia. 5.ed. Rio de Janeiro, Medsi, 1992.

43 DONGARI, A.; LAMBRIANIDIS, T. Periodontally derived pulpal lesions. Endod Dent Traumatol, v. 4, n. 2, p. 49-54, Apr. 1988. 
44 ENLOW, D.H. Crescimento facial. 3.ed. Philadelphia, Artes Médicas, 1993.

45 ENNES, J.P.; LARA, V.S. Comparative morphological analysis of the root developmental groove with the palato-gengival groove. Oral Dis, v. 10, n. 6, p. 378-82, Nov. 2004.

ESTRELA, C.; PEREIRA, H.L.; PÉCORA, J.D. Radicular Grooves in Maxillary Lateral Incisor: Case Report. Braz Dent J, v. 6, n. 2, p. 143-6, 1995.

47 ESPOSITO, P.T.; CUNNINGHAM, C.J. A comparison of canal preparation with nickel-titanium and stainless steel instruments. J Endod, v. 21, n. 4, p. 173-6, Apr. 1995.

48 EVERETT, F.G.; KRAMER, G.M. The disto-lingual groove in the maxillary lateral incisor; A periodontal hazard. J Periodontol, v. 43, n. 6, p. 352-61, June 1972.

FABRA-CAMPOS, H. Failure of endodontic treatment due to a palatal gengival groove in a maxillary lateral incisor with talon cusp and two root canals. J Endod, v. 13, n. 7, p. 342-5, July 1990.

50 FERREIRA, Z.A. et al. Treatment of a palatal groove-related periodontal bone defect. Quintessence Int, v. 31, n. 5, p. 342-5, May 2000.

51 FRIEDMAN, S.; GOULTSCHIN, J. the radicular palatal groove- a therapeutic modality. Endod Dent Traumatol, v. 4, n. 6, p. 282-6, Dec. 1988. concavities: a consideration in periodontal therapy. J Am Dent Assoc, v.114, n. 6, p. 811-4, June 1987. 
53 GAO, Z. et al. Scanning electron microscopic investigation of maxillary lateral incisors with a radicular lingual groove. Oral Surg Oral Med Oral Pathol, v. 68, n. 4, p. 462-6, Oct. 1989.

54 GHER, E.; VERNINO, A.R. Root morphology - clinical significance in pathogenesis and treatment of periodontal disease. J Am Dent Assoc, v.101, n. 10, p. 627-33, Oct. 1980.

55 GODOY, V.L. Reabsorção radicular em molares decíduos: Análises morfológicas macro e microscópica. Bauru, 1995.116 p. Dissertação (Mestrado) Faculdade de Odontologia de Bauru, Universidade de São Paulo.

56 GOERIG, A.C.; MICHELICH, R.J.; SHULTZ, H.H. Instrumentation of root canals in molar using the step-down technique. J Endod, v. 8, n. 12, p. 550-4, Dec. 1982.

57 GOON et al. Complex facial radicular groove in a maxillary lateral incisor. J Endod, v. 17, n. 5, p. 244-8, May 1991.

58 GOUND, T.G.; MAZE, G.I. Treatment options for the radicular groove: a review and discussion. Pract Periodont Aesthet Dent, v. 10, n. 3 , p. 369-75, Apr. 1998.

59 GRAY, H.; WILLIAMS, P.L.; BANNISTER, L.H. Gray's anathomy, New York, Churchill Livingstone, 1995.

60 GREENFELD, R.S.; CAMBRUZZI, J.V. Complexities of endodontic treatment of maxillary lateral incisors with anomalous root formation. Oral Surg Oral Med Oral Pathol, v. 62, n. 6, p. 82-8, Jul. 1986. 
61 GREGHI, S.L.A.; ALMEIDA, A.L.P.; RESENDE, D.R.B. Sulco papatogengival: um fator predisponente à destruição periodontal. Rev Assoc Paul Cir Dent, v. 53, n. 2, p. 145-9, Mar-Abr. 1999.

62 GUTIERREZ, J.H.; GARCIA, J. Microscopic and macroscopic investigation on results of mechanical preparation of root canals. Oral Surg Oral Med Oral Pathol, v. 25, n.1, p. 108-16, Jan.1968.

63 HARRIS, J.H.; OVERTON, E.E. ementoenamel defects in an unusual location. J Am Dent Assoc, v. 97, n. 8, p. 221-2, Aug. 1978.

64 HARRINGTON, G.W. The perio-endo question: differential diagnosis. Dent Clin North Am, v. 23, n. 4, p. 673-90, Oct. 1979.

65 HESS, J.C.; CULIERAS, M.J.; LAMIABLE, N.A. A scanning electron microscopic investigation of principal and accessory foramina on the root surfaces of human teeth: thoughts about endodontic pathology and therapeutics. J Endod, v.9, n.7, p.275-81, July 1983.

66 HOLEN, S. The radicular groove. J Am Dent Assoc, v. 97, n. 9, p. 441, Set. 1978.

67 HOU, G.L.; TSAI, C.C. Relationship between palato-radicular grooves and localizeed periodontitis. J Clin Periodontol, v. 20, n. 9, p.67882, Oct. 1993.

68 HU, J.R.; NAKASIMA, A.; TAKAHAMA, Y. Familial similarity in dental arch form and tooth position. J Craniofac Genet Dev Biol, v.12, n. 1, p. 33-40, Jan-Mar. 1992.

JENG, J.H.; LU, H.J.; HOU, L.T. Treatment of an Osseous Lesion Associated With a Severe Palato-Radicular Groove: A Case Report. J Periodontol, v. 63, n. 8, p. 708-12, Aug. 1992. 
JERNVALL, J. et al. The life history of an embryonic signaling center: BMP-4 induces p21 and is associated with apoptosis in the mouse tooth enamel knot. Development v.125, n. 2, p.161-169, Jan.1998.

71 KAWANO, et al. Characterization of dental epithelial progenitor cells derived from cervical-loop epithelium in a rat lower incisor. J Dent Res, v. 83, n. 2, p. 129-33, Feb. 2004.

72 KEREZOUDIS, N.P.; SISKOS, G.J.; TSATSAS, V. Bilateral buccal radicular groove in maxillary incisors: case report. Int Endod J, v. 36, n.12, p. 898-906, Dec. 2003.

73 KETTUNEN, P.; THESLEFF, I. Expression and function of fgfs-4, -8, and -9 suggest functional redundancy and repetitive use as epithelial signals during tooth morphogenesis. Dev Dyn, v. 211, n. 3, p. 25668, Mar. 1998.

74 KIRKHAM, D.B.; HOGE, H.W. Successful osseous regeneration in the treatment of radicular lingual groove: a case report. Periodontal Case Rep, v. 6,p. 46-7, 1984.

75 KOGON, S.L. The prevalence, location and conformation of palatoradicular grooves in maxillary incisors. J Periodontol, v. 57, n. 4, p. 231-4, Apr. 1986.

76 KOVACS, I. Contribution to the ontogenetic morphology of roots of human teeth. J Dent Res, v. 46, n. 5, p. 865-74, Sep-Oct. 1967.

77 KOZLOVSKY, A. et al. Facial radicular groove in a maxillary central incisor a case report. J Periodontol, v. 59, n. 9, p. 615-7, Sep. 1988. 
78 LANDIS, J.R.; KOCH, G.G. The measurement of observer agreement for categorical data. Biometrics, v.33, n.1, p.159-74, Mar. 1977. Bauru, 1993. 185 p. Dissertação (Mestrado) Faculdade de Odontologia de Bauru, Universidade de São Paulo.

80 LARA, V.S.; CONSOLARO, A.; BRUCE, R.B. Macroscopic and microscopic analysis of the palato-gingival groove. J Endod, v. 26, n. 6 , p. 345-50, Jun. 2000.

81 LAURIKKALA, J. et al. TNF Signaling via the ligand-receptor pair ectodysplasin and edar controls the function of epithelial signaling centers and is regulated by wnt and activin during tooth organogenesis. Dev Biol, v. 229, n. 2, p. 443-5, Jan. 2001.

82 LEE, K.W.; LEE, E.C.; POON, K.Y. Palato-Gingival Grooves in Maxillary Incisors. Brit Dent J, v. 124, n. 1, p. 14-8, Jan. 1968.

83 LEKNES, K.N.; LIE, T.; SELVIG, K.A. Root grooves: a risck factor in periodontal attachment loss. J Periodontol, v. 95, n. 9, p. 859-63, Sep. 1994.

84 LEONARDO, M.R.; LEAL, J.M. Endodontia, 3.ed. São Paulo, Panamericana, 1998.

85 LÉZOT, F. et al. Epithelial DIx-2 Homeogene Expression and Cementogenesis. J Histochem Cytochem, v. 48, n. 2, p. 277-84, Feb. 2000. 
MCCANN, J. T.; KELLER, D. L.; LABOUNTY, G. L. A modification of the muffle model system to study root canal morphology. J Endod, v. 16, n. 3, p. 114-5, Mar. 1990.

87 MASS, E.; AHARONI, K.; VARDIMON, A.D. Labial-cervical-vertical groove in maxillary permanent incisors - Prevalence, severity, and affected soft tissue. Qintessence Int, v. 36, n. 4, p. 281-5, apr. 2005.

MATTEWS D.C.; TABESH, M. Detection of localized tooth-related factors that predispose to periodontal infections. Periodontol 2000, v. 34, p. 136-50, 2004.

MAYNE, J.R.; MARTIN, I.G. The palatal radicular groove. Two case reports. Aust Dent J, v. 35, n. 3, p. 277-81, June 1990.

90 MEISTER, F. et al. Successful Treatment of A Radicular Lingual Groove: Case Report. J Endod, v. 9, n. 12, p. 561-4, Dec. 1983.

91 MELO, N.S. Projeção Cervical do Esmalte: Aspectos Morfológicos e suas Implicações Clínicas. Bauru, 1997. 130p. Dissertação (Mestrado) Faculdade de Odontologia de Bauru, Universidade de São Paulo.

92 MILES, A.E.W. History and General Organization of Dentitions. In:__. Structural and Chemiacal Organization of the Teeth. Academic Press, 1967. cap. 1, p. 3-41.

93 MORAES, S.H. Incisivo Lateral com duas raizes. Rev G Odontol, v. 31, n. 1, p. 108-9, Jan-Mar. 1983. 
94 NAMBA, K. ; ITO, K. Palatal radicular multigrooves associated with sever periodontal defects in maxillary central incisors. J Clin Periodontol, v. 28, n. 4, p. 372-375, Apr. 2001.

95 NELSEN, K. ; TAYLES, N. Missing lateral incisors in iron age southeast asians as possible indicators of dental agenesis. Arch Oral Biol, v. 46, n. 10, p. 963-71, Oct. 2001.

96 NEUVALD, L.R. Análise Microscópica da Junção Amelocementária: Com ênfase para os mecanismos envolvidos nas reabsorções cervicais externas. Bauru, 1997. 146p. Dissertação (Mestrado) Faculdade de Odontologia de Bauru, Universidade de São Paulo.

97 NEUVALD, L.R.; CONSOLARO, A. Cemento enamel junction: Microscopic analysis and external cervical resorption. J Endod v. 26 , n. 9 , p. 503-8, sep. 2000.

98 OHASAMA, A. et al. A Dual Role for Ikka in Tooth Development. Dev Cel, v. 6, n. 2, p. 219-27, Feb. 2004.

99 OEHLERS, F. A. C. Dens invaginatus (dilated composite odontome). Oral Surg, v. 10, n. 11, p. 1205-18, Nov. 1957.

100 OEHLERS, F. A. C. The radicular variety of dens invaginatus. Oral Surg, v. 11, n. 11, p.1251-60, Nov.1958.

101 OLIVEIRA, A.G. Associação da anadontia parcial com o tamanho e morfologia dos dentes permanentes, com 0 apinhamento dentario e com as dimensões do arco dentario de brasileiros. Bauru, 1988. 116p. Dissertação (Mestrado) Faculdade de Odontologia de Bauru, Universidade de São Paulo. 
102 PACK, A.R.C.; CHANDLER, N.P. A combined endodontic-periodontic lesion of development origin: a case report. N Z Dent J, v. 92, n. 6, p. 46-8, June 1996.

103 PAUL, B.F. Surgical manegement of the palato-radicular groove and associated periodontal lesion: a case presentation. Pract Periodont Aesth Dent, v. 5, p. 25-8, 1993.

104 PÉCORA, J.D.; CRUZ FILHO, A.M. Study of the Incidence of Radicular Grooves in Maxillary Incisors. Braz Dent J, v. 3, n. 1, p. 11-6, 1992.

105 PÉCORA, J.D. et al. In vitro study of the incidence of radicular grooves in maxillary incisors. Braz Dent J, v. 2, n. 1, p. 69-73, Jan. 1991.

106 PEDERSEN, P. O. The east greenland eskimo dentition. Copenhagen, Bianco Lunos Bogtrykkery, 1949.

107 PEIKOFF, M.D.; TROTT, J.R. An endodontic failure caused by an unusual anatomical anomaly. J Endod, v. 3, n. 9, p. 356-9. Sep. 1977.

108 PEIKOFF, M.D.; PERRY, J.B.; CHAPNICK, L.A. Endodontic Failure Attributable to a Complex Radicular Lingual Groove. J Endod, v. 11, n. 12, p. 573-7, Dec. 1985.

109 PINHEIRO, T.N.; BORTOLUZZI, E.A.; CONSOLARO, A. Análise bibliométrica de 47 casos de sulco palatogengival e apresentação de 10 casos clínicos. In: JORNADA ODONTOLÓGICA DE ARARAQUARA, 58., Araraquara. Anais da $58^{\circ}$ JOFOA. Araraquara: Faculdade de Odontologia de Araraquara - UNESP, 2004. 1 CD-rom. 
110 PINHO, T. et al. Developmental absence of maxillary lateral incisors in the Portuguese population. Eur J Orthod, v. 27, n. 5, p. 443-9, Oct. 2005.

111 PORCIÚNCULA, M.M. et al. Influência da presença do sulco palatoradicular no início e curso da doença periodontal crônica localizada. Etiologia, prevalência e tratamento. Rev Int Period Clin, v. 1, n. 1, p. 28-34, Jan. 2004.

112 PRICHARD, J. S. Advanced periodontal therapy. Philadelphia, W.B.Saunders Co, 1965, p.14.

113 RETHMAN, M.P. Treatment of a Palatal-Gingival Groove Using Enamel Matrix Derivative. Comp Contin Educ Dent, v. 22, n. 9, p. 792-7, Sep. 2001.

114 RIBEIRO, F.C. Distribuição das bactérias nas estruturas mineralizadas de dentes com necrose pulpar e granuloma apical. Bauru, 1997. 172p. Dissertação (Mestrado) Faculdade de Odontologia de Bauru, Universidade de São Paulo.

115 RIBEIRO, F.C.; CONSOLARO, A. Importância clínica y antropológica de la raiz distolingual em los molares inferiores permanentes. Endod, v. 15, n. 2, p. 72-8, Abr-Jun. 1997.

116 ROBISON, S.F.; COOLEY, R.L. Palatogingival groove lesions: Recognition and treatment. Gen Dent, v. 36, n. 4, p. 340-2, Jul-Aug. 1988.

117 SARKAR, L. et al. Wnt/Shh interactions regulate ectodermal boundary formation during mammalian tooth development. Proc Natl Acad Sci USA, v. 97,n. 9, p. 4520-4, Apr. 2000. 
118 SANTA-CECÍLIA M.; LARA, V.S.; MORAES, I.G. The palato-gingival groove a cause of failure in root canal treatment. Oral Surg Oral Med Oral Pathol, v. 85, n. 1, p. 94-8, Jan. 1998.

119 SANTANA, E.J.B. Estudo da prevalência e estudo morfológico das anomalias radiculares de número, tamanho e forma nos grupos dentários permanentes. Bauru, 1988. 206p. Dissertação (Mestrado) Faculdade de Odontologia da Bauru, Universidade de São Paulo.

120 SASAKI, T. et al. LEF1 is a critical epithelial survival factor during tooth morphogenesis. Dev Biol, v. 278, n. 1, p. 130-43, Feb. 2005.

121 SENA, K. et al. Gene Expression of growth differentiation factors in the developing periodontium of rat molars. J Dent Res, v. 82, n. 3, p.166-71, Mar. 2003.

122 SIMON, J.H.S.; GLICK, D.H.; FRANK, A.L. Predictable endodontic and periodontics failure as a result of radicular anomalies. Oral Surg, v. 31, n. 6, p. 123-6, June. 1971.

123 SIMON, J.H.S. et al. The radicular groove: its potential clinical significance. J Endod, v. 26, n. 5, p. 295-8, May 2000.

124 SCHÄFER, E.; CANKAY, R.; OTT, K. Malformations in maxillary incisors: case report of radicular palatal groove. Endod Dent Traumatol, v. 16, n. 3, p. 132-7, June 2000.

125 SHAJU, J.P. Palatogingival developmental groove. Qintessence Int, v. 32, n. 5, p. 349, May 2001.

126 SHAW, J.C.M. The teeth, the bony palatge and mandible in bantu races of south áfrica. London, Bale, Sons \& Danielsson Ltd., 1931. 
127 SHILOAH, J.; KOPCZYK, R.A. Developmental variations of tooth morphology and periodontal disease. J Am Dent Assoc, v. 99, n. 4, p. 627-30, Oct. 1979.

128 SKELTON-MACEDO, M.C.; CARDOSO, R.J.A.; BOMBANA, A.C. Sistema de corte transversal simplificado para estudo da morfologia do canal radicular e técnicas de preparo. Endod Clin Pract Educ Res, v. 1, n. 2, ISSN 1516-4055, Maio 1999.

129 SMITH, B.E.; CARROLL, B. Maxillary lateral incisor with two developmental grooves. Oral Surg Oral Med Oral Pathol, v. 70, n. 4, p. 523-5, Oct. 1990.

130 SMITH, M.M.; HALL, B.K. Development and evolutionary origins of vertebrate skeletogenic and odontogenic tissues. Biol Rev Camb Philos Soc, v. 65, n. 3, p. 277-373, Aug. 1990.

131 STEELE-PERKINS, G. et al. Essential role for NFI-C/CTF transcriptionreplication factor in tooth root development. Mol Cel Biol, v. 23, n. 3, p. $1075-84$, Feb. 2003.

STERRETT, J.D. Esthetic Considerations in Treating Periodontal Defects Associated with Bilateral Palatoradicular Grooves. J Esth Dent, v.7, n. 6, p. 244-50, 1995.

TAMSE, A.; PILO, R. A new muffle model system to study root canal morphology and instrumentation techniques. J Endod, v. 24, n. 8, p. 540-2, Oct. 1998.

134 TEN CATE, A.R. Oral histology: development, structure and function. 5.ed. St Louis, Mosby, 1998. 
135 THESLEFF I, ÅBERG T. Molecular regulation of tooth development. Bone v. 25, n. 1, p. 123-125. Jan.1999.

136 THOMAS, B.L. et al. Independent regulation of DIx2 expression in the epithelium and mesenchyme of the first branchial arch. Development, v. 127, n. 2, p. 217-24, Jan. 2000.

137 THOMAS, B.L. et al. Role of Dlx-1 and Dlx-2 genes in patterning of the murine dentition. Development, v. 124, n. 23, p. 4811-8, Dec. 1997.

138 TUCKER, A.S. et al. Fgf-8 determines rostral-caudal polarity in the first branchial arch. Development, v. 126, n. 1, p. 51-61, Jan. 1999.

139 VANDERSALL, D.C. Pearls grooves and projections. J Am Dent Assoc, v. 99, n. 5, p. 794, Nov. 1979.

140 VELloso, T. R. G.; CONSOLARO, A.; ENNES, J.P.; FURQUIN, L.Z.; OLIVEIRA, A.G. . Partial Anodontia: form and size of remaining teeth and orthodontics implications. In: 101st Annual Session Toronto, Ontário, Canada, 2001, Toronto. Orthodontics 2001. St Louis: American Association of Orthodontists, 2001. v. 1. p. 84-84.

141 VITAYA, C.T. Management of developmental anomalies in the maxillary incisors: case report. J Dent Assoc Thai, v. 40, n. 6, p. 269-76, Nov-Dec. 1990.

WALKER R.T. The disto-palatal groove in maxillary incisors, a predisponding factor in periodontal disease. J R Nav Med Serv, v. 62, p. 30-2. 1976.

143 WALTON, R.E. Histologic evaluation of different methods of enlarging the pulp canal space. J Endod, v. 10, n. 10, p. 304-11, Oct.1976. 
144 WEI, P.C. et al. Successful treatment of pulpal-periodontal combined lesion in a birooted maxillary lateral incisor with concomitant palatoradicular groove. A case report. J Periodontol, v. 70, n. 12, p. 1540-6, Dec. 1999.

145 WIDDOWSON, T.W. Special or dental anatomy and phisiology and dental histology human and comparative, 7.ed, v.2, London, Staples Press, 1952.

146 WITHERS, J.A. et al. The relationship of palato-gigival grooves to localized peridontal disease. J Periodontol, v. 52, n. 1, p. 41-4, Jan. 1981.

147 WU, M.K.; VAN DER SLUIS, L.W.M.; WESSELINK, P.R. The capability of two hand instrumentation tchniques to remove the inner layer of dentine in oval canals. Int Endod J, v.36, n.3, p. 218-24, Mar. 2003.

148 YAMASHIRO, T. TUMMERS, M. THESLEFF, I. Expression of bone morphogenetic proteins and msx genes during root formation. $\mathbf{J}$ Dent Res, v. 82,n. 3, p. 172-6, Mar. 2003.

149 ZAIA, A.A. et al. A Simple Method for the Analysis of Root Canal Preparation. J Endod, v. 23, n. 3 p. 172-4, Mar. 2000.

150 ZEICHNER-DAVID, M. et al. Role of Hertwig's Epithelial Root Sheath Cells in Tooth Root Development. Dev Dyn, v. 228, n. 4, p. 651-63, Dec. 2003.

151 ZEISZ, R.C.; NUCKOLLS, J. Dental Anatomy. London, Kimpton, 1949

152 ZHANG, Y.D. et al. Making a tooth: growth factors, transcription factors, and stem cells. Cel Res, v. 15, n. 5, p. 301-16, May 2005. 
153 ZUCKERMAN, O. et al. Residual dentin thickness in mesial roots of mandibular molars prepared with Lightspeed rotary instruments and Gates-Glidden reamers. Oral Surg Oral Med Oral Pathol, v. 96, n. 3, p. 351-5, Sep. 2003. 
$\mathcal{A B S \mathcal { T }} \mathcal{A C} \mathcal{T}$ 


\begin{abstract}
Frequency of the palatogengival groove and morphologic analysis of the root canals of affected teeth before and after root canal preparation.
\end{abstract}

The palatogengival groove represents an anomaly with favorable morphology to the accumulation of microorganisms and possible communication with the pulp chamber, leading to localized periodontal disease, dental caries, pulp and periapical diseases. It was aimed to investigate the origin, the diagnostic means and to collaborate for determination of prognostic measures based on the detection of difficulties with handling of the current clinical situations related to the groove. The frequency in 500 patients was evaluated, correlating the presence of the groove with individual characteristics end its presence in the family of the bearers. Also 20 permanent previously extracted upper incisors with the palatogengival groove were evaluated as to the root canal morphology macro and microscopically, before and after root canal preparation. The relationship of the pulp chamber with the external environment, in these specimens was evaluated. The specimens were observed macroscopically, by means of stereomicroscope, x-ray and analyzed through scanning electronic microscopy before and after root canal preparation using a modified muffle technique from BRAMANTE et al.. The prevalence of the palatogengival groove in 500 patients, was of $19,8 \%$, and the most affected tooth was the upper lateral incisor with $80,4 \%$ of prevalence, with unilateral and bilateral manifestation. It was detected the prevalence of $7,8 \%$ of groove related diseases. It was not detected differences between gender and skin color, with the presence of the defect. No correlations were observed between the presence of the palatogengival groove and the studied physical characteristics. It was identified the presence of the palatogengival groove in patients of the same family. The analysis of 20 upper incisors with palatogengival groove allowed the identification foramen, foraminas and exposed dentinal tubules in the radicular surface of the groove, communicating the pulp chamber with the periodontal compartment. Alterations in the outline and variations of the type of the cement enamel junction were also detected. The dentin removal produced by root canal instrumentation of the studied teeth was uniform, with no significant differences among the different dentinal walls or in the cervical, medium and apical fragments of the analyzed teeth. The dentinal wall related to the palatogengival groove was thinner before and after the root canal preparation compared with the remaining dentinal walls. 


\section{Universidade de São Paulo Faculdade de Odontologia de Bauru \\ Al. Dr. Octávio Pinheiro Brisolla, 9-75 - Bauru-SP-CEP 17012-901 - CP. 73 PABX (0XX14)235-8000 - FAX (0XX14)223-4679 \\ Comile de Ética en Pesquisa}

Processo $n^{\circ} 115 / 2003$

Bauru, 04 de novembro de 2003

Senhor Professor,

O projeto de pesquisa encaminhado a este Comitê de Ética em Pesquisa em Seres Humanos, denominado "Freqüência do sulco palatogengival e morfologia dos canais de dentes portadores antes e depois do preparo biomecânico", de autoria de Tiago Novaes Pinheiro, que será desenvolvido sob sua orientação, foi enviado ao relator para avaliação.

Na reunião de 29 de outubro de 2003 o parecer do relator, aprovando o projeto, foi aceito pelo Comitê, considerando que não existem infrações éticas pendentes.

Informamos que após o envio do trabalho concluído, este Comitê enviará o parecer final, que será utilizado para publicação do trabalho.

Atenciosamente,

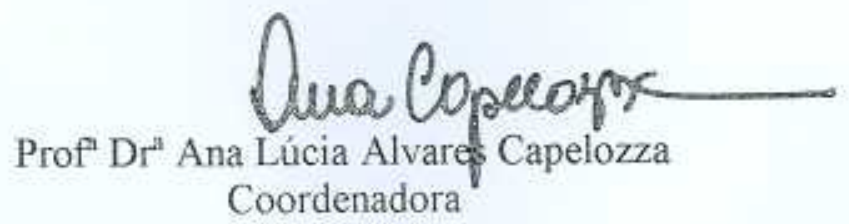

$11 \mathrm{~m}^{\circ} \mathrm{Sr}$. Prof. Dr. Alberto Consolaro

DD. Docente do Departamento de Estomatologia (Patologia) 